\title{
Water-Related Publications of the \\ U.S. Geological Survey in Minnesota, 1946-94
}

Compiled by G.L. Amos

U.S. Geological Survey

Open-File Report 95-297

Mounds View, Minnesota

1995 


\section{U.S. DEPARTMENT OF THE INTERIOR \\ BRUCE BABBITT, Secretary \\ U.S. GEOLOGICAL SURVEY \\ Gordon P. Eaton, Director}

For additional information write to:

District Chief

U.S. Geological Survey 2280 Woodale Drive

Mounds View, MN 55112
Copies of this report can be purchased from:

U.S. Geological Survey

Earth Science Information Center

Open-File Reports Section

Box 25286, MS 517

Denver Federal Center

Denver, CO 80225 


\section{Contents}

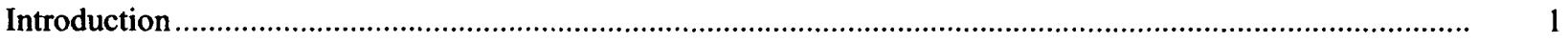

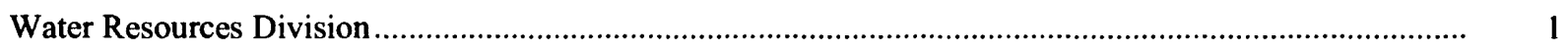

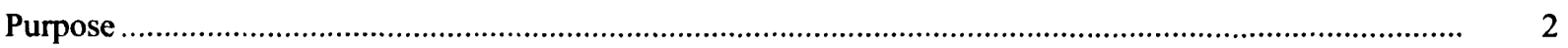

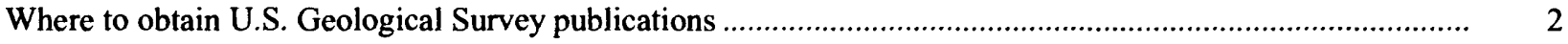

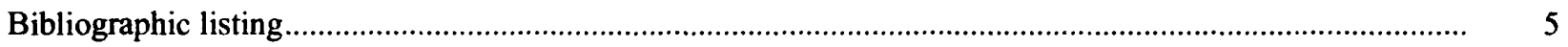

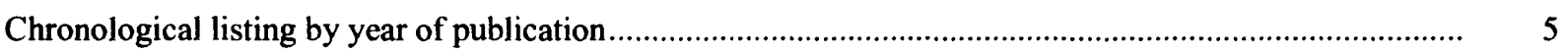

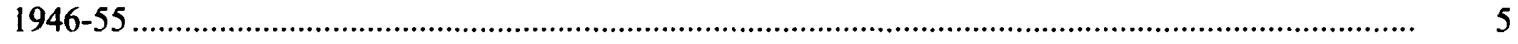

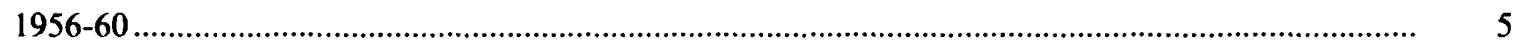

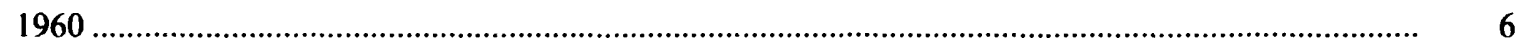

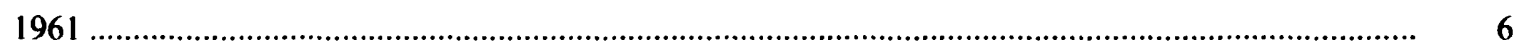

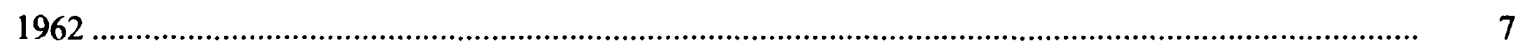

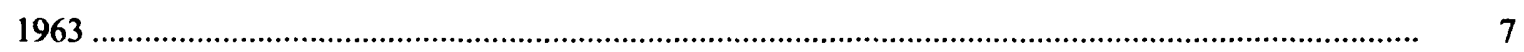

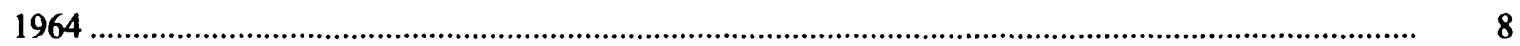

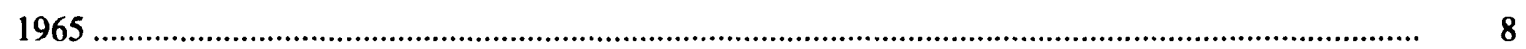

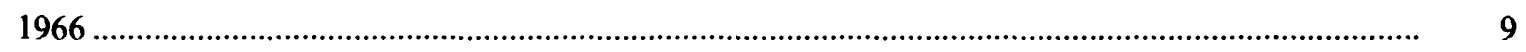

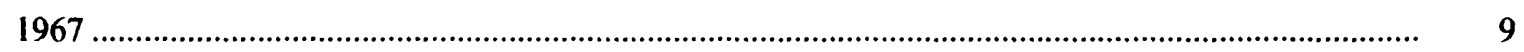

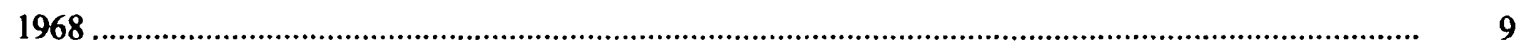

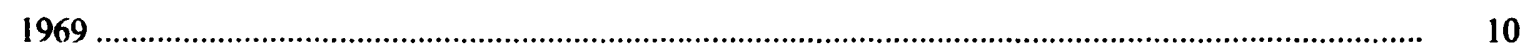

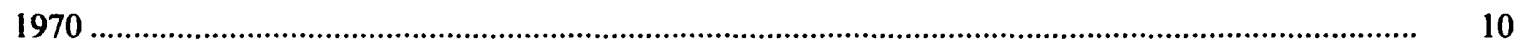

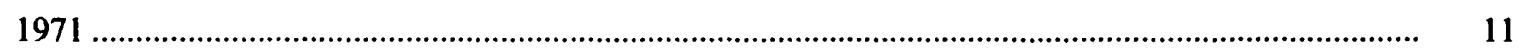

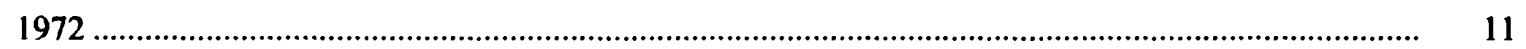

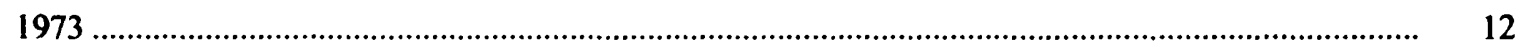

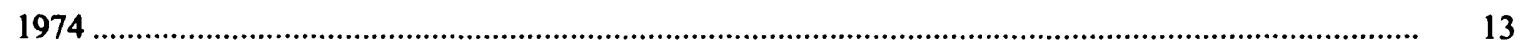

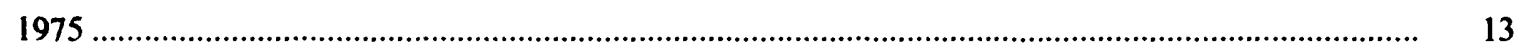

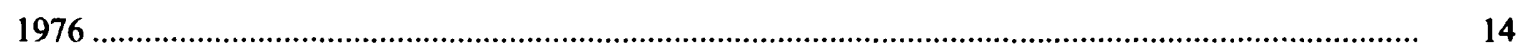

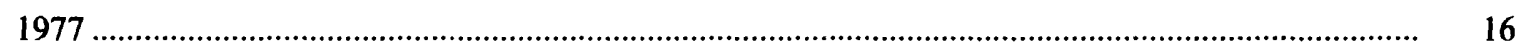

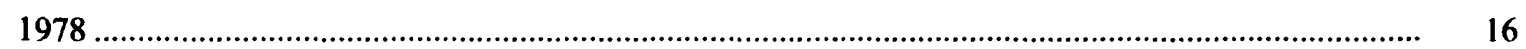

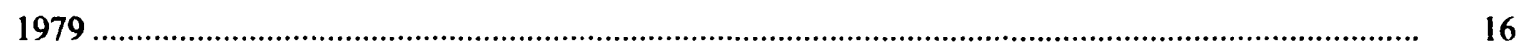

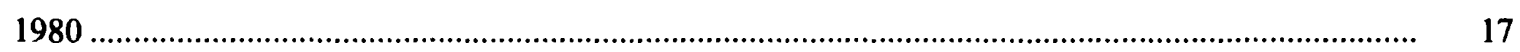

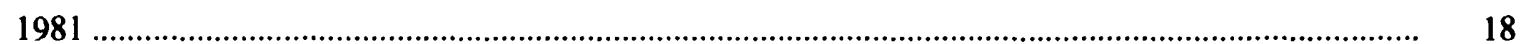

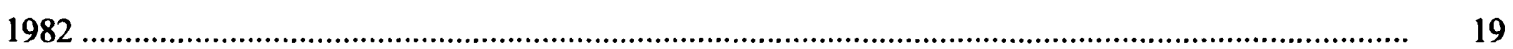

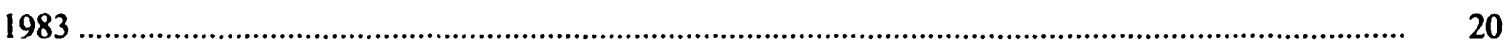

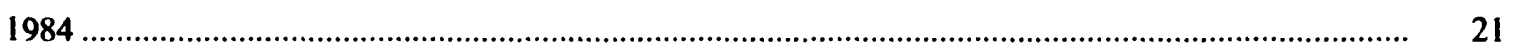

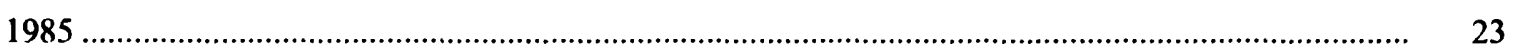

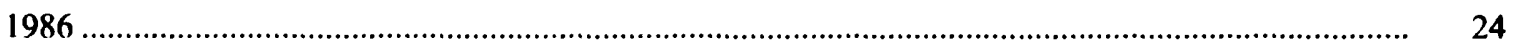

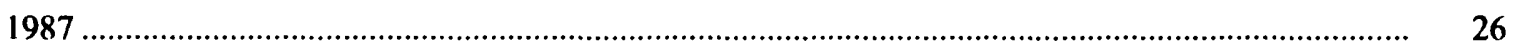

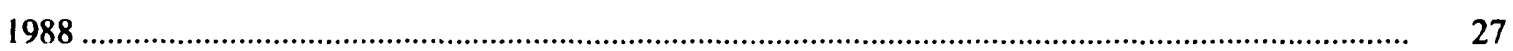

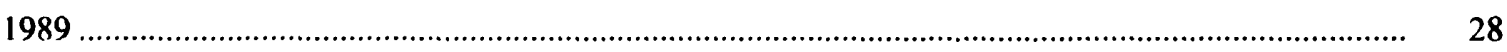

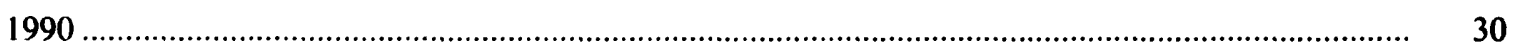

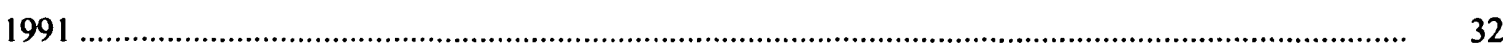

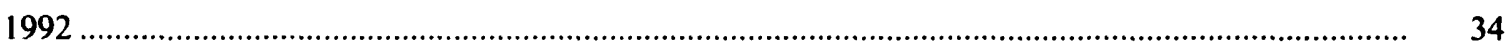

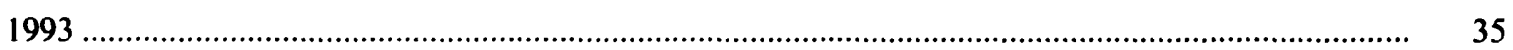

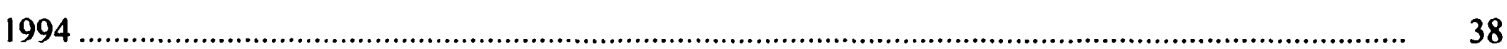




\section{Contents-Continued}

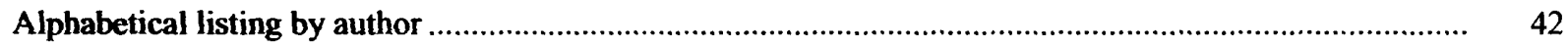

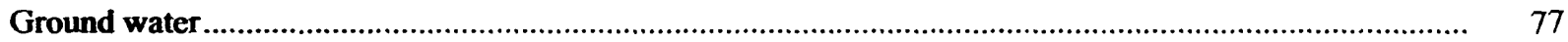

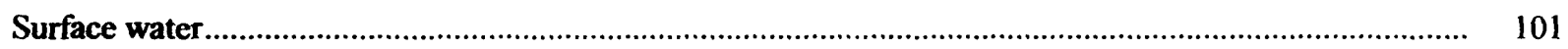

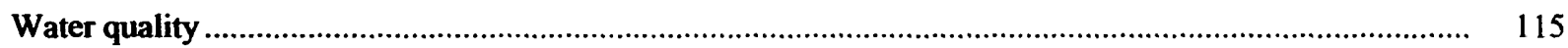

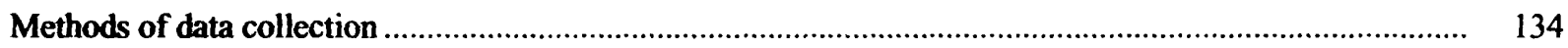

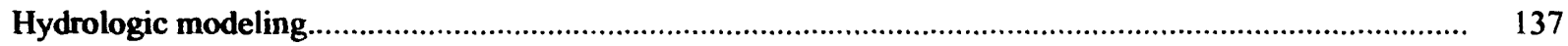

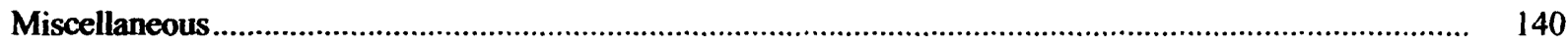

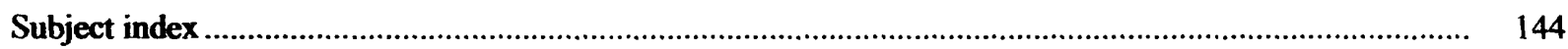

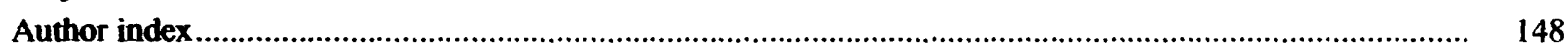

Illustrations

Figure 1. Map showing U.S. Geological Survey offices and county locations in Minnesota ......................... 


\section{Water-Related Publications of the \\ U.S. Geological Survey in Minnesota, 1946-94}

\section{Compiled by G.L. Amos}

\section{Introduction}

The U.S. Geological Survey was established as an agency in the Department of the Interior by an Act of Congress in 1879. The growth of its scientific investigations has paralleled the growth of the United States and has contributed to that development. Initially, the mission of the U.S. Geological Survey was to assess the mineral resources of the United States. However, as need arose, the Survey mission expanded and the organization eventually was divided into several operating Divisions and Offices, each addressing specific aspects of natural resources. As a result of its expanding research and fact-finding role, the U.S. Geological Survey has become the Nation's largest earth science research agency, the largest civilian mapmaking agency, the primary source of data on the Nation's surface-water and ground-water resources. and the employer of the largest number of professional earth scientists. Today's programs, which serve a diversity of needs and users, include:

* Conducting detailed assessments of the energy and mineral potential of the Nation's land and offshore areas.

* Investigating and issuing warnings of earthquakes. volcanic eruptions, landslides, and other geologic and hydrologic hazards.

* Conducting research on the geologic structure of the Nation.

* Studying the geologic features, structure, processes, and history of the other planets in our solar system.

* Conducting topographic surveys of the Nation and preparing topographic and thematic maps and related cartographic products.

* Developing and producing digital cartographic data bases and products.

* Collecting data on a routine basis to determine the quantity, quality, and use of surface and ground water.
* Conducting water-resources appraisals to describe the consequences of alternative plans for developing land and water resources.

* Conducting research in hydraulics and hydrology. and coordinating all Federal water-data acquisition.

* Using remotely sensed data to develop new cartographic, geologic, and hydrologic research techniques for natural resources planning management.

* Providing earth-science information through an extensive publications program and network of public access points.

Along with its continuing commitment to meet the growing and changing earth-science needs of the Nation, the Survey remains dedicated to its original mission to collect, analyze, interpret, publish, and disseminate information about the natural resources of the Nation--providing "Earth Science in the Public Service."

\section{Water Resources Division}

The mission of the Water Resources Division is to provide the hydrologic information and understanding needed for the optimum utilization and management of the Nation's water resources for the overall benefit of the people of the United States.

This is accomplished, in large part, through cooperation with other Federal and non-Federal agencies by:

* Collecting, on a systematic basis, data needed for the continuing determination and evaluation of the quantity, quality, and use of the Nation's resources.

* Conducting analytical and interpretive waterresources appraisals describing the presence, availability, and the physical, chemical, and biological characteristics of surface water and ground water.

* Conducting supportive basic and problem-oriented research in hydraulics, hydrology, and related fields of science to improve the scientific basis for investigations and measurement techniques, and to understand 
hydrologic systems sufficiently well to quantitatively predict their response to stress, either natural or manmade.

* Disseminating the water data and the results of these investigations and research through reports, maps, computerized information services, and other forms of public release.

* Coordinating the activities of Federal agencies in the acquisition of water data for streams, lakes, reservoirs, estuaries, and ground water.

* Providing scientific and technical assistance in hydrologic fields to other Federal, State, and local agencies, to licensees of the Federal Power Commission, and to international agencies on behalf of the Department of State.

* Acquiring, developing, and disseminating information on water-related natural hazards such as droughts, floods, landslides, land subsidence, mudflows, and volcanoes.

* Administering the provisions of the Water Resources Research Act of 1984, which include the State Water Resources Research Institutes and the Research Grants and Contracts Programs.

* Supporting the provisions of the National Environment Policy Act of 1969 and managing the Geological Survey conduct of natural resources surveys in response to the Comprehensive Environmental Response, Compensation, and Liability Act (Superfund Act) of 1980.

The U.S. Geological Survey has expanded its work in Minnesota to meet growing demand for scientific data by Federal, State, and local agencies, for use in the planning and management of one of the State's most precious resources—water. The Minnesota District of the Water Resources Division, with the main office in Mounds View, and a field office in Grand Rapids, continues to investigate the presence, quantity, quality, distribution, and movement of surface and ground water. Its activities include the systematic collection, analysis, and interpretation of data; the investigation of water demand for public supply, industrial, domestic, and agricultural purposes; and the research and development of new techniques to improve the scientific basis of water data collection and investigative principles.

\section{Purpose}

This report lists the water-related publications written by or in cooperation with the U.S. Geological Survey in Minnesota for 1946-94. These publications are released in scientific journals, conference proceedings, State or local cooperator report series, and as U.S. Geological Survey reports.

The bibliographic listings are divided into eight sections. The first section is a chronological listing b" year of publication. The second section is an alphabetical listing of publications by author. Sections three through eight list publications by subject. The subjects are ground water, surface water, water quality, methods of data collection, hydrologic modeling, and miscellaneous. In the subject listings publications are arranged alphabetically by author. In addition, two indexes are provided. The first is to help locate publications by additional subjects and geographic areas. The second is to help locate publications by author.

\section{Where to Obtain U.S. Geological Survey Publications}

Most publications listed in this report are availabl ? through the U.S. Geological Survey office in Mounds View, Minnesota (fig. 1); however, a listing of additic nal information resources are provided.

Current U.S. Geological Survey releases are described in a monthly pamphlet, "New Publications of the Geological Survey." You may have your name ad ted to the mailing list and receive the monthly catalog free. Write to:
Mailing List Unit
Geological Survey
582 National Center
Reston, VA 22092

Open-File Reports, Water-Resources Investigations Reports, and popular leaflets, pamphlets, and booklets may be purchased from:
U.S. Geological Survey
Earth Science Information Center
Open-File Report Section
Box 25286, MS 517
Denver, CO 80225

Professional Papers, Bulletins, Water-Supply Papers, Techniques of Water Resources Investigations, Circulars, Earthquake lnformation Bulletins, and maps may be purchased from:
U.S. Geological Survey
Branch of Distribution and Map Distribution
Box 25286
Denver, CO 80225 
Flood-prone area maps of Minnesota may be obtained from the U.S. Geological Survey office in Mounds View, Minnesota.

Map, benchmark, and aerial photograph information is available from:

National Cartographic Information Center

U.S. Geological Survey

12201 Sunrise Valley Drive

Reston, VA 22092

Requests for miscellaneous information on water and on programs in other states may be referred to:

Public Inquiries Office

U.S. Geological Survey

1220I Sunrise Valley Drive

Reston, VA 22092

The Geological Survey National Center maintains a library with an extensive earth-sciences collection.

Local libraries may obtain books, periodicals, and maps through interlibrary loan by writing to:

U.S. Geological Survey Library

950 National Center

Room 4-A-100

12201 Sunrise Valley Drive

Reston, VA 22092

Hydrologic Investigations Atlases and Hydrologic Unit Maps may be purchased from:

U.S. Geological Survey

Branch of Distribution and Map Distribution

Box 25286

Denver, CO 80225

Topographic maps of Minnesota also may be obtained from:

Minnesota Geological Survey

2642 University Avenue

St. Paul, Minnesota 55114 


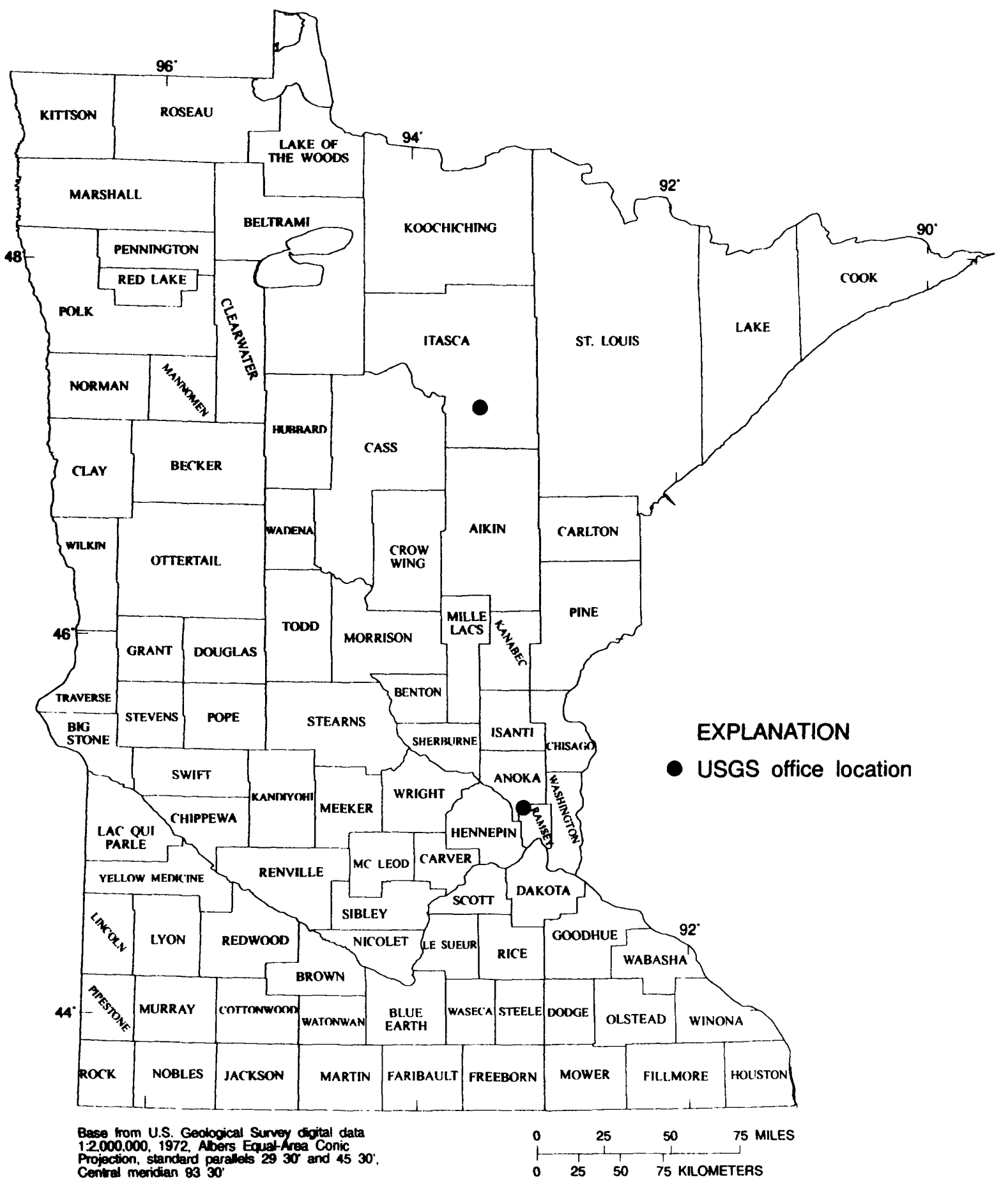

Figure 1. U.S. Geological Survey offices and county locations in Minnesota 


\section{BIBLIOGRAPHIC LISTING}

\section{Chronological Listing by Year of Publication}

\section{6-55}

Byers, A.C., Wenzel, L.K., Laird, W.M., and Dennis, P.E., 1946, Ground water in the Fargo-Moorhead area, North Dakota and Minnesota: U.S. Geological Survey, 72 p.

Prior, C.H., 1949, Magnitude and frequency of floods in Minnesota: Minnesota Department of Conservation, Division of Waters Bulletin 1, $128 \mathrm{p}$.

Thompson, G.L., 1949, Depositional patterns in sinuous melt-water channel deposits near Marshall, Lyon County, Minnesota and their hydrologic significance: Unpublished report on file with U.S. Geological Survey in Mounds View, Minnesota, $24 \mathrm{p}$.

Akin, P.D., 1951, Preliminary report on ground-water conditions in the Cloquet area, Carlton County, Minnesota: U.S. Geological Survey, 11 p.

U.S. Geological Survey, 1951, Surface-water supplies of the Mesabi Iron Range: Minnesota Department of Conservation, Division of Waters Bulletin 5, $117 \mathrm{p}$.

Akin, P.D., and Jones, J.R., 1952, Geology and ground-water resources of the Cloquet area, Carlton County, Minnesota: Minnesota Department of Conservation, Division of Waters Bulletin 6, $63 \mathrm{p}$.

Prior, C.H., Schneider, Robert, and Durum, W.H., 1953, Water resources of the Minneapolis-St. Paul area, Minnesota: U.S. Geological Survey Circular 274, 49 p.

\section{6-60}

Moyle, J.B., 1956, Relationships between the chemistry of Minnesota surface waters and wildlife management: Journal of Wildlife Management, v. 20, no. 3, p. 303-320.

Straka, G.C., and Schneider, Robert, 1957, Graphs of ground water levels in Minnesota through 1956: Minnesota Department Conservation, Division of Waters Bulletin 9, $42 \mathrm{p}$.

U.S. Geological Survey, 1957, Supplemental chemical analysis of surface waters in the Red River of the North Basin, North Dakota and Minnesota: Unpublished report on file with U.S. Geological Survey in Mounds View, Minnesota, $40 \mathrm{p}$.

Books, K.G., Schwartz, G.M., Meuschke, J.L., and Dempsey, W.J., 1958, Aeromagnetic maps of eastern Roseau County, Minnesota: U.S. Geological Survey Geophysical Investigations Map GP-140, 2 sheets, scale 1:63,360. 1958, Aeromagnetic map of Kittson County, Minnesota: U.S. Geological Survey Geophysical Investigations Map GP-142, 2 sheets, scale 1:63,360.

1958, Aeromagnetic maps of western Roseau County, Minnesota: U.S. Geological Survey Geophysical Investigations Map GP-141, 2 sheets, scale 1:63,360.

Colby, V.C., and Witzgman, F.W., 1958, Operator's manual on the visual-accumulation tube method for sedimentation analysis of sands: Federal Inter-Agency Sedimentation Project Report K, 28 p.

Schneider, Robert, 1958, Correlation of ground-water levels and air temperatures in the winter and spring in Minnesota: Minnesota Department of Conservation, Division of Waters Technical Paper 1, 17 p. 
Schneider, Robert, and Rodis, H.G.. 1959, Aquifers in meltwater channels along the southwest flank of the Des Moines lobe, Lyon County, southwestern Minnesota [abs.]: Geological Society of America, v. 70, no. 12, r. 1671.

U.S. Geological Survey, 1959, Chemical analysis of surface waters, Minnesota, October 1956 to September 1958: Unpublished report on file with U.S. Geological Survey in Mounds View, Minnesota, 16 p.

\section{0}

Bingham, J.W., 1960, Basic geology and ground-water data for Clay County, Minnesota: Minnesota Departmen+ of Conservation, Division of Waters Bulletin 8, $138 \mathrm{p}$.

Cotter, R.D., and Young. H.L., 1960, Municipal water supplies on the Mesabi and Vermillion Iron Ranges, northeastern Minnesota: U.S. Geological Survey, Ground Water Series Basic Data Release 1, 61 p.

Norvitch, R.F., 1960, Ground water in alluvial channel deposits, Nobles County, Minnesota: Minnesota Department of Censervation, Division of Waters Bulletin 14, $23 \mathrm{p}$.

Rodis, H.G., and Schneider, Robert, 1960, Occurrence of ground waters of low hardness and of high chloride content in Lyon County, Minnesota: U.S. Geological Survey Circular 423, 3 p.

Schiner, G.R., 1960, Ground-water exploration and test pumping in the Halma-Lake Bronson area, Kittson County, Minnesota: U.S. Geological Survey Open-File Report, 53 p.

Skinner, J.V., 1960, An automatic-tracking device for visual-accumulation-tube analysis: Water Resources Bulletin, November, p. 135-137.

\section{1}

Cotter, R.D., and Rogers, J.E., 1961, Exploratory drilling for ground water in the Mountain Iron-Virginia area, S" Louis County, Minnesota: U.S. Geological Survey Water-Supply Paper 1539-A, 13 p.

Liesch, B.A.,1961, Geohydrology of the Jordan aquifer in the Minneapolis-St. Paul area, Minnesota: Minnesota Department of Conservation, Division of Waters Technical Paper 2, $24 \mathrm{p}$.

Minnesota Department of Conservation, 1961, Water resources of the Minneapolis-St. Paul metropolitan area: Minnesota Department of Conservation, Division of Waters Bulletin 11, $52 \mathrm{p}$.

Prior, C.H., and Hess, J.H., 1961, Floods in Minnesota magnitude and frequency: Minnesota Department of Conservation, Division of Waters Bulletin 12, $142 \mathrm{p}$.

Rodis, H.G., 1961, Availability of ground water in Lyon County, Minnesota: U.S. Geological Survey Circular 444, $7 \mathrm{p}$.

1961, Geology and occurrence of ground water in Lyon County, Minnesota: U.S. Geological Survey Open-File Report, 43 p.

1961, Interpretation of geologic and ground-water conditions from field data in Lyon County, Minnesota: Unpublished report on file with U.S. Geological Survey in Mounds View, Minnesota, 22 p.

1961, Use of water-well data in interpreting occurrence of aquifers in northeastern Lyon County, Minnesota: Geological Society of America Bulletin, v. 72, p. 1275-1278.

Schneider, Robert, and Rodis, H.G., 1961, Aquifers in melt-water channels along the southwest flank of the Des Moines lobe, Lyon County, Minnesota: U.S. Geological Survey Water-Supply Paper 1539-F, 10 p. 
Colby, V.C., and Witzgman, F.W., 1962, Instructions for US P-61-Al suspended-sediment sampler: Federal InterAgency Sedimentation Project, 9 p.

Maclay, R.W., and Schiner, G.R., 1962, Aquifers in buried shore and glaciofluvial deposits along the Gladstone Beach of glacial Lake Agassiz near Stephen, Minnesota: U.S. Geological Survey Professional Paper 450-D, p. D170D172.

Norvitch, R.F., 1962, Geology of the Vermillion end moraine, Nett Lake Indian Reservation, Minnesota: U.S. Geological Survey Professional Paper 450-D, p. D130-D132.

Rainwater, F.H., 1962, Stream composition of the contcrminous United States: U.S. Geological Survey Hydrologic Investigations Atlas HA-61, 3 sheets.

Rogers, J.E., 1962, Reconnaissance of ground-water conditions in the Duluth municipal airport area, Minnesota: U.S. Geological Survey Open-File Report, 18 p.

Schneider, Robert, 1962, An application of thermometry to the study of ground water: U.S. Geological Survey WaterSupply Paper 1544-B, 16 p.

Scott, C.H., and Skinner, J.V., 1962, Valve position indicator for P-46 sampler: Water Resources Bulletin, February, p. 9-10.

\section{3}

Brown, R.F., and Cotter, R.D., 1963, Water and the Minnesota Iron Range: U.S. Geological Survey, 16 p.

Jones, J.R., Akin, P.D., and Schneider, Robert, 1963, Geology and ground-water conditions in the southern part of the Camp Ripley Military Reservation, Morrison County, Minnesota: U.S. Geological Survey Water-Supply Paper 1669-A, 32 p.

Liesch, B.A., and Norvitch, R.F., 1963, Geology and ground-water conditions in the Chisholm-Dewey Lake area, St. Louis County, Minnesota: Unpublished report on file with U.S. Geological Survey in Mounds View, Minnesota, $68 \mathrm{p}$.

Maclay, R.W., 1963, Evaluation of ground water near Stephen, Minnesota: Unpublished report on file with U.S. Geological Survey in Mounds View, Minnesota, $24 \mathrm{p}$.

Maderak, M.L., 1963, Quality of waters, Minnesota-A compilation, 1955-62: Minnesota Department of Conservation, Division of Waters Bulletin 21, $104 \mathrm{p}$.

Norvitch, R.F., 1963, Reconnaissance geology and hydrology on the Nett Lake Indian Reservation, Minnesota: Unpublished report on file with U.S. Geological Survey in Mounds View, Minnesota, $35 \mathrm{p}$.

Norvitch, R.F., Schneider, Robert, and Godfrey, R.G., 1963, Geology and hydrology of the Elk River, Minnesota, nuclear reactor site: U.S. Geological Survey Bulletin 1133-C, 25 p.

Rodis, H.G., 1963, Geology and occurrence of ground water in Lyon County, Minnesota: U.S. Geological Survey Water-Supply Paper 1619-N, 41 p.

Schiner, G.R., 1963, Ground-water exploration and test pumping in the Halma-Lake Bronson area, Kittson County, Minnesota: U.S. Geological Survey Water-Supply Paper 1619-BB, 38 p.

Straka, G.C., and Miller, W.A., 1963, Graphs of ground-water levels in Minnesota, 1957-1961: Minnesota Department of Conservation, Division of Waters Bulletin 18, 58 p. 


\section{4}

Bath, G.D., Schwartz, G.M., and Gilbert, F.P., 1964, Aeromagnetic and geologic map of northwestern Minnesota: U.S. Geological Survey Geophysical Investigations Map GP-471, 1 sheet, scale 1:250,000.

Colby, V.C., 1964, Instructions for use of BM-54 and BM-60 bed-material samplers for the collection of sampler to be analyzed for organic substances: Federal Inter-Agency Sedimentation Project, $3 \mathrm{p}$.

Cotter, R.D., and Rogers, J.E., 1964, Glacial geology of the Mountain Iron-Virginia-Eveleth area Mesabi Iron Range, Minnesota: U.S. Geological Survey Professional Paper 501-C, p. C144-C146.

Cotter, R.D., Young, H.L., and Winter, T.C., 1964, Preliminary surficial geologic map of the Mesabi-Vermillion Iron Range area, northeastern Minnesota: U.S. Geological Survey Miscellaneous Geologic Investigations Map I-403, 1 sheet, scale 1:125,000.

Langford, R.H., 1964, Chemical quality of the water resources Kittson, Marshall, and Roseau Counties, Minnesota: Unpublished report on file with U.S. Geological Survey in Mounds View, Minnesota, 168 p.

Maderak. M.L., 1964, Relation of chemical quality of water to recharge to the Jordan Sandstone in the MinneapolisSt. Paul area, Minnesota: U.S. Geological Survey Professional Paper 501-C, p. C176-C179.

McGuinness, C.L., 1964, Generalized map showing annual runoff and productive aquifers in the conterminous United States: U.S. Geological Survey Hydrologic Investigations Atlas HA-194, 1 sheet, scale 1:5,000,000.

Norvitch, R.F., 1964, Geology and ground-water resources of Nobles County and part of Jackson County, Minnesota: U.S. Geological Survey Water-Supply Paper 1749, 70 p.

Oakes, E.L., 1964, Bedrock topography of the eastern and central Mesabi Range, northeastern Minnesota: U.S. Geological Survey Miscellaneous Geologic Investigations Map I-389, 4 sheets.

Schiner, G.R., and Schneider, Robert, 1964, Geology and ground-water conditions of the Redwood Falls area Redwood County, Minnesota: U.S. Geological Survey Water-Supply Paper 1669-R, 46 p.

Skinner, J.V., and Colby, V.C., 1964, Operation and maintenance of US BM-54 bed material sampler: Federal InterAgency Sedimentation Project Report M, 14 p.

\section{5}

Colby, V.C., 1965, Operating instructions for US DH-48 suspended-sediment hand sampler: Federal Inter-Agen :y Sedimentation Project Report J, 5 p.

Cotter, R.D., Young, H.L., Petri, L.R., and Prior, C.H., 1965, Ground and surface water in the Mesabi and Vermillion Iron Range area, northeastern Minnesota: U.S. Geological Survey Water-Supply Paper 1759-A, p. A1-A36.

1965, Water resources in the vicinity of municipalities on the central Mesabi Iron Range, northeastern Minnesota: U.S. Geological Survey Water-Supply Paper 1759-D, 20 p.

1965, Water resources in the vicinity of municipalities on the east-central Mesabi Iron Range, northeastern Minnesota: U.S. Geological Survey Water-Supply Paper 1759-E, 23 p.

1965, Water resources in the vicinity of municipalities on the eastern Mesabi Iron Range, northeastern Minnesota: U.S. Geological Survey Water-Supply Paper 1759-F, 27 p.

1965. Water resources in the vicinity of municipalities on the west-central Mesabi Iron Range, northeastern Minnesota: U.S. Geological Survey Water-Supply Paper 1759-C, 21 p.

1965, Water resources in the vicinity of municipalities on the western Mesabi Iron Range, northeastern Minnesota: U.S. Geological Survey Water-Supply Paper 1759-B, 24 p. 
Feth, J.H., 1965, Preliminary map of the conterminous United States showing depth to and quality of shallowest ground water containing more than 1,000 parts per million dissolved solids: U.S. Geological Survey Hydrologic Investigations Atlas HA-199, 31 p., 2 sheets, scale 1:3,168,000.

Maclay, R.W., Winter, T.C., and Pike, G.M., 1965, Water resources of the Middle River watershed, northwestern Minnesota: U.S. Geological Survey Hydrologic Investigations Atlas HA-201, 3 sheets, scale 1:250,000.

Maderak, M.L., 1965, Chemical quality of ground water in the Minneapolis-St. Paul area, Minnesota: Minnesota Department of Conservation, Division of Waters Bulletin 23, $44 \mathrm{p}$.

Thompson, G.L., 1965, Hydrology of melt-water channels in southwestern Minnesota: U.S. Geological Survey WaterSupply Paper I809-K, 1 I p.

\section{6}

Cotter, R.D., and Bidwell, L.E., 1966, Water resources of the Pomme de Terre River watershed, west-central Minnesota: U.S. Geological Survey Hydrologic Investigations Atlas HA-220, 4 sheets, scale 1:250,000.

Cotter, R.D., Bidwell, L.E., Oakes, E.L., and Hollenstein, G.H., 1966, Water resources of the Big Stone Lake watershed, west-central Minnesota: U.S. Geological Survey Hydrologic Investigations Atlas HA-213, 4 sheets, scale $1: 250.000$.

Maclay, R.W., 1966, Reconnaissance of the geology and ground-water resources in the Aurora area, St. Louis County, Minnesota: U.S. Geological Survey Water-Supply Paper 1809-U, 20 p.

\section{7}

Guetzkow, L.C., and Gunard, K.T., 1967, Small stream flood investigations in Minnesota, October 1958 to September 1965: U.S. Geological Survey Open-File Report, 162 p.

Maclay, R.W., and Winter. T.C., 1967, Geochemistry and ground-water movement in northwestern Minnesota: Ground Water, v. 5, no. I, p. 11-19.

Maclay, R.W., Winter, T.C., and Pike, G.M., 1967. Water resources of the Two Rivers watershed, northwestern Minnesota: U.S. Geological Survey Hydrologic Investigations Atlas HA-237, 4 sheets, scale 1:250,000.

Winter, T.C., Maclay, R.W., and Pike, G.M., 1967, Water resources of the Roseau River watershed, northwestern Minnesota: U.S. Geological Survey Hydrologic Investigations Atlas HA-241, 3 sheets, scale 1:250,000.

\section{8}

Cotter, R.D., and Bidwell, L.E., 1968, Water resources of the Lac qui Parle River watershed, southwestern Minnesota: U.S. Geological Survey Hydrologic Investigations Atlas HA-269, 4 sheets, scale 1:250,000.

Cotter, R.D., Bidwell, L.E., VanVoast, W.A., and Novitzki, R.P., 1968, Water resources of the Chippewa River watershed, west-central Minnesota: U.S. Geological Survey Hydrologic Investigations Atlas HA-286, 4 sheets, scale $1: 250,000$.

Lindholm, G.F., 1968, Geology and water resources of the Hibbing area, northeastern Minnesota: U.S. Geological Survey Hydrologic Investigations Atlas HA-280, 3 sheets, scale 1:24,000.

Maclay, R.W., Winter, T.C., and Bidwell, L.E., 1968, Water resources of the Mustinka and Bois de Sioux Rivers watershed, west-central Minnesota: U.S. Geological Survey Hydrologic Investigations Atlas HA-272, 4 sheets, scale $1: 250,000$.

Oakes, E.L., and Bidwell, L.E., 1968, Water resources of the Mississippi headwaters watershed, north-central Minnesota: U.S. Geological Survey Hydrologic Investigations Atlas HA-278, 4 sheets, scale 1:250,000. 
Skinner, J.V., 1968. Field test of an x-ray sediment-concentration gage: American Society of Civil Engineers, Hy. 2, no. $5868,3 \mathrm{p}$.

1968. Field test results of the Model B panametrics radioisotope gage for monitoring suspended-sediment concentration in rivers and streams: Federal Inter-Agency Sedimentation Project, $37 \mathrm{p}$.

VanVoast, W.A., and Novitzki, R.P., 1968, Ground-water flow related to streamflow and water quality: Water Resources Research, v. 4, no. 4, p. 769-775.

\section{9}

Guetzkow. L.C., and Carlson, G.H., 1969, Small stream flood investigations in Minnesota, October 1958 to Septem ber 1967: U.S. Geological Survey Open-File Report, 174 p.

Maclay, R.W., Bidwell, L.E., and Winter, T.C., 1969, Water resources of the Buffalo River watershed, west-central Minnesota: U.S. Geological Survey Hydrologic Investigations Atlas HA-307, 3 sheets, scale 1:250,000.

Miller, W.A., and Straka, G.C., 1969, Graphs of ground-water levels in Minnesota, 1962-1966: U.S. Geological Survey Open-File Report, $54 \mathrm{p}$.

Novitzki, R.P., VanVoast, W.A., and Jerabek, L.A., 1969, Water resources of the Yellow Medicine River watersh @d, southwestern Minnesota: U.S. Geological Survey Hydrologic Investigations Atlas HA-320, 3 sheets, scale 1:250,000.

Reeder, H.O., 1969, Ground water for irrigation in the Perham area, Otter Tail County, west-central Minnesota: U.S. Geological Survey Open-File Report, $56 \mathrm{p}$.

Ropes, L.H., 1969, Ground-water resources of the St. James area, south-central Minnesota: U.S. Geological Survey Hydrologic Investigations Atlas HA-334, 1 sheet, scale 1:62,500.

Ropes, L.H., Brown, R.F., and Wheat, D.E., 1969, Reconnaissance of the Red Lake River, Minnesota: U.S. Geological Survey Hydrologic Investigations Atlas HA-299, 1 sheet, scale 1:250,000.

Schneider, W.J., and Spieker, A.M., 1969, Water for the cities-the outlook: U.S. Geological Survey Circular 601-A, $6 \mathrm{p}$.

VanVoast, W.A., 1969, Ground water for irrigation near Lake Emily, Pope County, west-central Minnesota: U.S. Geological Survey Open-File Report, 29 p.

1969, Profiles of regional ground-water flow in glacial deposits in Minnesota based on existing well data, in Annual Engineering Geology and Soils Engineering Symposium, 7th, Moscow, Idaho [Proceedings], p. 84-100.

Winter, T.C., Bidwell, L.E., and Maclay, R.W., 1969, Water resources of the Otter Tail River watershed, west-cer tral Minnesota: U.S. Geological Survey Hydrologic Investigations Atlas HA-296, 4 sheets.

\section{0}

Anderson, D.B., and Schwob, H.H., 1970, Floods of April-May 1969 in upper midwestern United States: U.S. Geological Survey Open-File Report, 555 p.

Bidwell, L.E., Winter, T.C., and Maclay, R.W., 1970, Water resources of the Red Lake River watershed, northwes ${ }^{+} \cdot \mathrm{rn}$ Minnesota: U.S. Geological Survey Hydrologic Investigations Atlas HA-346, 4 sheets, scales 1:500,000 an $1: 250,000$.

Guy, H.P., 1970, Sediment problems in urban areas: U.S. Geological Survey Circular 601-E, 8 p.

Lindholm, G.F., 1970, An appraisal of ground water for irrigation in the Wadena area, central Minnesota: U.S. Geological Survey Water-Supply Paper 1983, 56 p. 
Mann, W.B., IV, and Collier, C.R., 1970, A proposed streamflow data program for Minnesota: U.S. Geological Survey Open-File Report, 75 p.

Oakes, E.L., 1970, Geology and ground-water resources of the Grand Rapids area, north-central Minnesota: U.S. Geological Survey Hydrologic Investigations Atlas HA-322, 2 sheets, scale 1:48,000.

Schneider, W.J., 1970, Hydrologic implications of solid-waste disposal: U.S. Geological Survey Circular 601-F, 10 p.

Skinner, J.V., and Beverage, J.P., 1970, Operators manual for proportional frequency controller: Federal lnter-Agency Sedimentation Project, $42 \mathrm{p}$.

Thomas, H.E., and Schneider, W.J., 1970, Water as an urban resource and nuisance: U.S. Geological Survey Circular 601-D, 9 p.

VanVoast, W.A., Jerabek, L.A., and Novitzki, R.P., 1970, Water resources of the Redwood River watershed, southwestern Minnesota: U.S. Geological Survey Hydrologic Investigations Atlas HA-345, 3 sheets.

Winter, T.C., Bidwell, L.E., and Maclay, R.W., 1970, Water resources of the Wild Rice River watershed, northwestern Minnesota: U.S. Geological Survey Hydrologic Investigations Atlas HA-339, 4 sheets, scale 1:250,000.

\section{1}

Carlson, G.H., 1971, Flooded area of Lake St. Croix Beach, Minnesota: U.S. Geological Survey Open-File Report, 4 p.

1971, Flooded area of Lakeland Shores, Minnesota: U.S. Geological Survey Open-File Report, 5 p.

1971, Flooded area of Montevideo, Minnesota: U.S. Geological Survey Open-File Report, 6 p.

Gunard, K.T., 1971, Flooded area of St. Mary's Point, Minnesota: U.S. Geological Survey Open-File Report, 6 p.

Gunard, K.T., and Guetzkow, L.C., 1971, Small stream flood investigations in Minnesota, October 1958 to September 1969: U.S. Geological Survey Open-File Report, 174 p.

Helgesen, J.O., 1971, Appraisal of ground water for irrigation in the Little Falls area, Morrison County, Minnesota: U.S. Geological Survey Open-File Report, 54 p.

Mann, W.B., IV, 1971, Flow characteristics of Minnesota streams: Minnesota Department of Natural Resources Technical Paper 4, $265 \mathrm{p}$.

VanVoast, W.A., 1971, Ground water for irrigation in the Brooten-Belgrade area, west-central Minnesota: U.S. Geological Survey Water-Supply Paper 1899-E, 24 p.

1971, Ground water for irrigation near Lake Emily, Pope County, west-central Minnesota: U.S. Geological Survey Water-Supply Paper 1899-J, 28 p.

Winter, T.C., 1971, Sequence of glaciation in the Mesabi-Vermillion Iron Range area, northeastern Minnesota: U.S. Geological Survey Professional Paper 750-C, p. C82-C88.

\section{2}

Lindholm, G.F., Oakes, E.L., Ericson, D.W., and Helgesen, J.O., 1972, Water resources of the Crow Wing River watershed, central Minnesota: U.S. Geological Survey Hydrologic lnvestigations Atlas HA-380, 4 sheets, scale 1:250,000.

Maclay, R.W., Winter, T.C., and Bidwell, L.E., 1972, Water resources of the Red River of the North drainage basin in Minnesota: U.S. Geological Survey Water-Resources Investigations Report 1-72, 129 p. 
Mann, W.B., IV, and McBride, M.S., 1972, The hydrologic balance of Lake Sallie, Becker County, Minnesota: U.S. Geological Survey Professional Paper 800-D, p. 189-191.

McIntosh, W.L., and Eister, M.F., 1972, Geologic map index of Minnesota Part B, 1953-1970: U.S. Geological Surviy Minnesota Geologic Map Index, 1 sheet.

Reeder, H.O., 1972, Availability of ground water for irrigation from glacial outwash in the Perham area, Otter Tai County, Minnesota: U.S. Geological Survey Water-Supply Paper 2003, 45 p.

Rickert, D.A., and Spieker, A.M., 1972, Real-estate lakes: U.S. Geological Survey Circular 601-G, 19 p.

Schneider, W.J., Rickert, D.A., and Spieker, A.M.. 1972, Role of water in urban planning and management: U.S. Geological Survey Circular 601-H, $10 \mathrm{p}$.

VanVoast, W.A., Broussard, W.L., and Wheat, D.E., 1972, Water resources of the Minnesota River-Hawk Creek watershed, southwestern Minnesota: U.S. Geological Survey Hydrologic Investigations Atlas HA-391, 3 shee`c, scale $1: 250,000$.

Winter, T.C., 1972, An approach to the design of statewide or regional ground water information systems: Water Resources Research, v. 8, no. 1, p. 222-230.

Winter, T.C., and Norvitch, R.F., 1972, Field trip guidebook for hydrogeology of the Twin Cities Artesian Basin: Minnesota Geological Survey Guidebook 8, 35 p.

\section{3}

Anderson, D.B., 1973, Drainage ditch inventory, State of Minnesota: Unpublished report on file with U.S. Geological Survey in Mounds View, Minnesota, $230 \mathrm{p}$.

Beverage, J.P., and Skinner, J.V., 1973, Automatic tracking attachment for the visual-accumulation-tube size analyzer: Federal Inter-Agency Sedimentation Project, 15 p.

Broussard, W.L., Anderson, H.W., Jr., and Farrell, D.F., 1973, Water resources of the Cottonwood River watershed, southeastern Minnesota: U.S. Geological Survey Hydrologic Investigations Atlas HA-466, 3 sheets, scales, $1: 253,400,1: 500,000$, and $1: 250,000$.

Guetzkow, L.C., 1973, Small stream flood investigations in Minnesota, October 1958 to September 1971: U.S. Geological Survey Open-File Report, 159 p.

Guetzkow, L.C., and Carlson, G.H., 1973, Flood-plain areas of the lower Minnesota River: U.S. Geological Survev Open-File Report 74-15, 12 sheets.

Helgesen J.O., 1973, Appraisal of ground water for irrigation in the Little Falls area, Morrison County, Minnesotz: U.S. Geological Survey Water-Supply Paper 2009-D, 40 p.

Helgesen J.O., and Lindholm, G.F., 1973, Geology and water-supply potential of the Anoka Sand Plain aquifer, Minnesota: U.S. Geological Survey Open-File Report, 19 p.

Helgesen J.O., Lindholm, G.F., Broussard, W.L., and Ericson, D.W., 1973, Water resources of the Kettle River watershed, east-central Minnesota: U.S. Geological Survey Hydrologic Investigations Atlas HA-437, 4 sheets, scale 1:250,000.

Norvitch, R.F., Ross, T.G., and Brietkrietz, Alex, 1973, Water resources outlook for the Minneapolis-St. Paul metropolitan area, Minnesota: U.S. Geological Survey Open-File Report 73-203, 219 p.

Saboe, C.W., 1973, Flooded area of Stillwater, Minnesota: U.S. Geological Survey Open-File Report, 6 p. 
Winter, T.C., 1973, Hydrogeology of glacial drift. Mesabi Iron Range, northeastern Minnesota: U.S. Geological Survey Water-Supply Paper 2029-A, 23 p.

Winter, T.C., Cotter, R.D., and Young, H.L., 1973. Petrography and stratigraphy of glacial drift, Mesabi-Vermillion Iron Range area, northeastern Minnesota: U.S. Geological Survey Bulletin 1331-C, 41 p.

\section{4}

Anderson, H.W., Jr., Farrell, D.F., and Broussard, W.L., 1974, Water resources of the Blue Earth River watershed. south-central Minnesota: U.S. Geological Survey Hydrologic Investigations Atlas HA-525, 3 sheets, scale $1: 500,000$.

1974, Water resources of the lower Minnesota River watershed, south-central Minnesota: U.S. Geological Survey Hydrologic Investigations Atlas HA-526, 3 sheets, scale 1:500,000.

Anderson, H.W., Jr., Farrell, D.F., Broussard, W.L., and Felsheim, P.E., 1974, Water resources of the Cannon River watershed, southeastern Minnesota: U.S. Geological Survey Hydrologic Investigations Atlas HA-522, 3 sheets, scales $1: 250,000$ and $1: 500,000$.

Collier, C.R., 1974, An approximation of sediment yields from watersheds in Minnesota, in Winter Meeting, Chicago, Illinois, December 10-13, 1974, Proceedings: American Society of Agricultural Engineers, 9 p.

Ericson, D.W., Lindholm, G.F., and Helgesen, J.O., 1974, Water resources of the Rum River watershed, east-central Minnesota: U.S. Geological Survey Hydrologic Investigations Atlas HA-509, 3 sheets, scales 1:250,000 and 1:500,000.

Hicks, J.K., 1974, Coon Rapids pool hydrographic study: U.S. Geological Survey Open-File Report, 6 p.

Larson, S.P., Mann, W.B., IV, Steele, T.D., and Susag, R.H., 1974, Time-trend and river-reach assessments in water quality of the Mississippi River, Minneapolis-St. Paul, metropolitan area, Minnesota [abs.]: EOS, Transactions, American Geophysical Union, v. 55, no. 12, p. 1114.

Lindholm, G.F., Farrell, D.F., and Helgesen, J.O., 1974, Water resources of the Crow River watershed, south-central Minnesota: U.S. Geological Survey Hydrologic Investigations Atlas HA-528, 3 sheets, scale 1:500,000.

Lindholm, G.F., Helgesen, J.O., Broussard, W.L., and Farrell, D.F., 1974. Water resources of the lower St. Croix River watershed, east-central Minnesota: U.S. Geological Survey Hydrologic Investigations Atlas HA-490, 3 sheets, scales $1: 250,000$ and $1: 500,000$.

1974, Water resources of the Snake River watershed, east-central Minnesota: U.S. Geological Survey Hydrologic Investigations Atlas HA-488, 3 sheets, scales 1:250,000 and 1:500,000.

Reeder, H.O., and Norvitch, R.F., 1974, Hydrogeologic reconnaissance of ground-water pollution in the Pine Bend area, Dakota County, Minnesota: U.S. Geological Survey Open-File Report, 27 p.

U.S. Geological Survey, 1974, Status of projects in Minnesota, 1974-75 fiscal years: U.S. Geological Survey, 49 p.

Winter, T.C., 1974, The natural quality of ground water in Minnesota: Minnesota Department of Natural Resources Bulletin 26, $25 \mathrm{p}$.

\section{5}

Anderson, H.W., Jr., Farrell, D.F., Broussard, W.L., and Hult, M.F., 1975, Water resources of the Zumbro River watershed, southeastern Minnesota: U.S. Geological Survey Hydrologic Investigations Atlas HA-543, 3 sheets, scale $1: 250,000$. 
Broussard, W.L., Farrell, D.F., Anderson, H.W., Jr., and Felsheim, P.E., 1975, Water resources of the Root River watershed, southeastern Minnesota: U.S. Geological Survey Hydrologic Investigations Atlas HA-548, 3 sheets, scale $1: 250,000$.

Farrell, D.F., Broussard, W.L., Anderson, H.W., Jr., and Hult, M.F., 1975, Water resources of the Cedar River watershed, southeastern Minnesota: U.S. Geological Survey Hydrologic Investigations Atlas HA-552, 3 sheets, scale $1: 250,000$.

Ficke, J.F., and Hawkinson, R.O., 1975, The National Stream Quality Accounting Network (NASQAN)-Some questions and answers: U.S. Geological Survey Circular 719, 23 p.

Guetzkow, L.C., and Gunard, K.T., 1975, Small stream flood investigations in Minnesota, October 1958 to Septeml $\%$ 1973: U.S. Geological Survey Open-File Report, 161 p.

Have, M.R., 1975, A water-quality assessment of the Burham Creek watershed, Polk County, Minnesota: U.S. Geological Survey Open-File Report 75-647, 15 p.

1975, Some limnological aspects of 20 selected lakes in Eagan and Apple Valley, Minnesota: U.S. Geological Survey Open-File Report 75-528, 44 p.

Helgesen J.O., Ericson, D.W., and Lindholm, G.F., 1975, Water resources of the Mississippi and Sauk Rivers watershed, central Minnesota: U.S. Geological Survey Hydrologic Investigations Atlas HA-534, 3 sheets, scale 1:250,000.

Helgesen J.O., Lindholm, G.F., and Ericson, D.W., 1975, Water resources of the Lake of the Woods watershed, northcentral Minnesota: U.S. Geological Survey Hydrologic Investigations Atlas HA-544, 2 sheets, scale 1:500,000.

Larson. S.P., McBride, M.S., and Wolf, R.J., 1975, Digital models of a glacial outwash aquifer in the Pearl-Sallie Lakes area, west-central Minnesota: U.S. Geological Survey Water-Resources Investigations Report 75-40, 39 p.

Larson-Higdem, D.C., Larson, S.P., and Norvitch, R.F., 1975, Configuration of the water table and distribution of downward leakage to the Prairie du Chien-Jordan aquifer in the Minneapolis-St. Paul metropolitan area, Minnesota: U.S. Geological Survey Open-File Report 75-342, 33 p.

Lindskov, K.L., 1975, Data summary of June-July 1975 floods in eastern North Dakota and northwestern Minneso+a: U.S. Geological Survey Open-File Report 75-565, 15 p.

McBride, M.S., 1975, Ground water for irrigation in the Viking Basin, west-central Minnesota: U.S. Geological Survey Water-Resources Investigations Report 75-23, 48 p.

McBride, M.S., and Pfannkuch, H.O., 1975, The distribution of seepage within lakebeds: U.S. Geological Survey Journal of Research, v. 3, no. 5, p. 505-512.

Reeder, H.O., 1975, Ground water in the Souris-Red-Rainey region: Unpublished report on file with U.S. Geological Survey in Mounds View, Minnesota, $44 \mathrm{p}$.

1975, Injection-pipe system for artificial recharge: U.S. Geological Survey Journal of Research, v. 3, no. 4, p. 501-503.

U.S. Geological Survey, 1975, Status of projects in Minnesota, fiscal years 1975-76: U.S. Geological Survey, 55 p.

\section{6}

Anderson, H.W., Jr., Broussard, W.L., Farrell, D.F., and Felsheim, P.E., 1976, Water resources of the Rock River watershed, southwestern Minnesota: U.S. Geological Survey Hydrologic Investigations Atlas HA-555, 3 sheets, scale 1:250,000. 
Anderson, H.W., Jr., Broussard, W.L., Farrell, D.F., and Hult, M.F., 1976, Water resources of the Des Moines River watershed, southwestern Minnesota: U.S. Geological Survey Hydrologic Investigations Atlas HA-553, 3 sheets, scales $1: 250,000$ and $1: 500,000$.

Druffel, Leroy, Emmett, W.W., Schneider, V.R., and Skinner, J.V., 1976, Laboratory hydraulic calibration of the Helley-Smith bed-load-sediment sampler: U.S. Geological Survey Open-File Report 76-752, 63 p.

Ericson, D.W., Lindholm, G.F., and Helgesen, J.O., 1976, Water resources of the Rainey Lake watershed, northeastern Minnesota: U.S. Geological Survey Hydrologic Investigations Atlas HA-556, 2 sheets, scale 1:1,000,000.

Helgesen J.O., Lindholm, G.F., and Ericson, D.W., 1976, Water resources of the Little Rock River watershed, northeastern Minnesota: U.S. Geological Survey Hydrologic Investigations Atlas HA-551, 2 sheets, scale 1:500,000.

Larson, S.P., 1976, An appraisal of ground water for irrigation in the Appleton area, west-central Minnesota: U.S. Geological Survey Water-Supply Paper 2039-B, 34 p.

Larson, S.P., Mann, W.B., IV, Steele, T.D., and Susag, R.H., 1976, Graphic and analytical methods for assessments of stream-water quality - Mississippi River in the Minneapolis-St. Paul metropolitan area, Minnesota: U.S. Geological Survey Water-Resources Investigations Report 76-94, 55 p.

Larson-Higdem, D.C., 1976, Map showing altitude of the bedrock surface in Minnesota: U.S. Geological Survey Open-File Report 76-788, 1 sheet.

Lindholm, G.F., Helgesen, J.O., and Ericson, D.W., 1976, Water resources of the Fork River watershed, north-central Minnesota: U.S. Geological Survey Hydrologic Investigations Atlas HA-549, 2 sheets, scale 1:500,000.

Lindholm, G.F., and Norvitch, R.F., 1976, Ground water in Minnesota: U.S. Geological Survey Open-File Report 76$354,100 \mathrm{p}$.

1976, Remote sensing as an aid in water-resources studies in Minnesota: U.S. Geological Survey Open-File Report 76-213, $63 \mathrm{p}$.

McBride, M.S., 1976, Hydrology of lakes in the Minneapolis-St. Paul metropolitan area-A summary of available data: U.S. Geological Survey Water-Resources Investigations Report 76-85, 317 p.

Reeder, H.O., Wood. W.W., Ehrlich, G.G., and Sun, R.J., 1976, Artificial recharge through a well in a fissured carbonate rock, West St. Paul, Minnesota: U.S. Geological Survey Water-Supply Paper 2004, 80 p.

Skinner, J.V., 1976, Instructions for sampling with depth-integrating, suspended-sediment samplers D-74, D-74AL, D-74TM, and D-74AL-TM: Federal Inter-Agency Sedimentation Project, 12 p.

Skinner, J.V., and Beverage, J.P., 1976, Instrumentation automatic collection of sediment data, in Federal InterAgency Sedimentation Conference, 3rd, Denver, Colorado, March 22-25, 1976, Proceedings: Federal InterAgency Sedimentation Project, p. 7-1-7-16.

Trescott, P.C., Pinder, G.F., and Larson, S.P., 1976, Finite-difference model for aquifer simulation in two dimensions with results of numerical experiments: U.S. Geological Survey Techniques of Water-Resources Investigations, book 7 , chap. $\mathrm{Cl}, 116 \mathrm{p}$.

U.S. Geological Survey, 1976, Hydrologic unit map-1974, State of Minnesota: U.S. Geological Survey, 1 sheet, scale 1:500,000.

-1976, Status of projects in Minnesota, fiscal years 1976 and 1977: U.S. Geological Survey, 36 p.

Winter, T.C., and Pfannkuch, H.O., 1976, Hydrogeology of a drift-filled bedrock valley near Lino Lakes, Anoka County, Minnesota: U.S. Geological Survey Journal of Research, v. 4, no. 3, p. 267-276. 
Wolf, R.J., 1976, Buried aquifers in the Brooten-Belgrade and Lake Emily areas, west-central Minnesota - Factors related to developing water for irrigation: U.S. Geological Survey Water-Resources Investigations Report 76$100,72 \mathrm{p}$.

\section{7}

Guetzkow, L.C., 1977, Techniques for estimating magnitude and frequency of floods in Minnesota: U.S. Geologic ${ }^{1}$ Survey Water-Resources Investigations Report 77-31, 33 p.

Guetzkow, L.C., and Gunard, K.T., 1977, Small stream flood investigations in Minnesota, October 1958 to Septemb?r 1975: U.S. Geological Survey Open-File Report 77-39, 161 p.

Helgesen J.O., 1977, Ground-water appraisal of the Pineland Sands area, central Minnesota: U.S. Geological Survey Water-Resources Investigations Report 77-102, 49 p.

Helgesen J.O., and Lindholm, G.F., 1977, Geology and water-supply potential of the Anoka Sand Plain aquifer, Minnesota: Minnesota Department of Natural Resources Technical Paper 6, 17 p.

Lindskov, K.L., 1977, Low-flow characteristics of Minnesota streams: U.S. Geological Survey Water-Resources Investigations Report 77-48, $197 \mathrm{p}$.

Nordin, C.F., and Skinner, J.V., 1977, Sediment sampling for deep fast currents, in International Association for Hydraulic Research, 17th, Badan Baden, Germany, August 14-19, 1977 [Proceedings], p. 606-609.

Payne, G.A., 1977, Baseline water quality of Long Meadow Lake, Ponds AP-9 and AP-10 and Black Dog Creek, Hennepin and Dakota Counties, Minnesota: U.S. Geological Survey Open-File Report 77-424, 56 p.

U.S. Geological Survey, 1977, Status of projects in Minnesota, fiscal years 1977 and 1978: U.S. Geological Survev, $59 \mathrm{p}$.

Winter, T.C., and Wright, H.E., Jr., 1977, Paleohydrologic phenomena recorded by lake sediments: EOS, Transactions, American Geophysical Union, v. 58, no. 4, p. 188-195.

\section{8}

Adolphson, D.G., and Jannis, J.A., 1978, Status of projects in Minnesota, fiscal year 1978: U.S. Geological Surve», $101 \mathrm{p}$.

Olcott, P.G., Ericson, D.W., Felsheim, P.E., and Broussard, W.L., 1978, Water resources of the Lake Superior watershed, northeastern: U.S. Geological Survey Hydrologic Investigations Atlas HA-582, 2 sheets, scales $1: 500,000$ and $1: 1,000,000$.

Olcott, P.G., and Siegel, D.I., 1978, Physiography and surficial geology of the copper-nickel study region, northeastern Minnesota: U.S. Geological Survey Open-File Report 78-51, 22 p.

Reeder, H.O., 1978, Summary appraisals of the Nation's ground-water resources-Souris-Red-Rainey Region: U.S. Geological Survey Professional Paper 813-K, 25 p.

Skinner, J.V., 1978, Instructions for the battery pack BP-76 HD: Federal Inter-Agency Sedimentation Project, 3 p.

Warne, S.A., 1978, Map showing low-flow frequency of Minnesota streams: U.S. Geological Survey Open-File Report 78-132, 1 sheet.

1979

Carlson, G.H., and Gunard, K.T., 1979, Small stream flood investigations in Minnesota, October 1958 to Septemt or 1977: U.S. Geological Survey Open-File Report 79-1061, 194 p. 
Greeson, P.E., ed., 1979, A supplement to methods for collection and analysis of aquatic biological and microbiological samples: U.S. Geological Survey Techniques of Water-Resources Investigations, book 5, chap. A4, 92 p.

Hult, M.F., 1979, Design of a network for monitoring ground-water quality in Minnesota: U.S. Geological Survey Open-File Report 79-1164, $44 \mathrm{p}$.

Jannis, J.A., and Diedrich, M.M., 1979, Status of projects in Minnesota fiscal year 1979: U.S. Geological Survey, 79 p.

Latkovitch, V.J.. 1979, Flood of July 5-7, 1978 on the South Fork Zumbro River at Rochester, Minnesota: U.S. Geological Survey Water-Resources Investigations Report 79-1583, 1 sheet.

1979, Hydrologic data for floods of July 1978 in southeast Minnesota and southwest Wisconsin: U.S. Geological Survey Open-File Report 79-1166, 29 p.

Lindholm, G.F., Ericson, D.W., Broussard, W.L., and Hult, M.F., 1979, Water resources of the St. Louis River watershed, northeastern Minnesota: U.S. Geological Survey Hydrologic Investigations Atlas HA-586, 3 sheets.

Norvitch, R.F., and Walton, M.S., eds., 1979, Geologic and hydrologic aspects of tunneling in the Twin Cities area, Minnesota: U.S. Geological Survey Miscellaneous Geologic Investigations Map I-11 57, 7 sheets, scales $1: 24,000$ and $1: 48,000$.

Payne, G.A., 1979, Water-quality reconnaissance of lakes in Voyageurs National Park, Minnesota: U.S. Geological Survey Open-File Report 79-556, 40 p.

Siegel, D.I., 1979, Potential hydrologic effects of peat mining in the Red Lake peatlands, north-central MinnesotaA project plan: U.S. Geological Survey Open-File Report 79-1591, 9 p.

Skinner, J.V., 1979, Instructions for the peristaltic pump, RP-77: Federal Inter-Agency Sedimentation Project, 5 p.

1979, Operating instructions D-77 suspended-sediment sampler: Federal Inter-Agency Sedimentation Project. $5 \mathrm{p}$.

\section{0}

Anderson, H.W., Jr., 1980, Minnesota standards for coding ground-water site inventory data: Unpublished report on file with U.S. Geological Survey in Mounds View, Minnesota, 57 p.

Ayers, M.A., Payne, G.A., and Have, M.R., 1980, Effects of urbanization on the water quality of lakes in Eagan, Minnesota: U.S. Geological Survey Water-Resources Investigations Report 80-71, 42 p.

Ayers, M.A., Payne, G.A., and Oberts, G.L., 1980, Quality of runoff from small watersheds in the Twin Cities metropolitan area, Minnesota_A project plan: U.S. Geological Survey Open-File Report 80-592, 31 p.

Carlson, G.H., and Guetzkow, L.C., 1980, Flood-plain areas of the Mississippi River mile 866.8 to mile 888.0: U.S. Geological Survey Water-Resources Investigations Report 80-972, 8 sheets.

Diedrich, M.M., and Jannis, J.A., 1980, Status of projects in Minnesota, fiscal year 1980: U.S. Geological Survey, 99 p.

Ericson, D.W., Holmen, O.O., and Latkovitch, V.J., 1980, Flood of April-May 1979 in Red River of the North Basin, North Dakota and Minnesota: U.S. Geological Survey Water-Resources Investigations Report 80-1 176, 2 sheets.

Giacomini, E.G., Wolf, R.J., Payne, G.A., and Adolphson, D.G., 1980, Hydrologic characteristics of Elim, Skunk, and Deer Creeks, Upper Nemadji River Basin, Minnesota: U.S. Geological Survey Open-File Report 80-47, 65 p.

Have, M.R., 1980, Water quality of Rogers Lake, Dakota County, Minnesota: U.S. Geological Survey WaterResources Investigations Report 80-5, $35 \mathrm{p}$. 
Lindholm, G.F., 1980, Ground-water appraisal of sand plains in Benton, Sherburne, Stearns, and Wright Counties, central Minnesota: U.S. Geological Survey Water-Resources Investigations Report 80-1285, 103 p.

Myette, C.F., 1980, Hydrologic budget for Eagle Lake near Willmar, Minnesota: U.S. Geological Survey Open-File Report 80-163, $13 \mathrm{p}$.

Payne, G.A., 1980, Baseline water quality of Schmidt, Hornbeam, and Horseshoe Lakes, Dakota County, Minnesota: U.S. Geological Survey Water-Resources Investigations Report 80-3, 38 p.

Siegel, D.I., 1980, Dissolution kinetics of selected silicate minerals under acid conditions [abs.]: EOS, Transactions, American Geophysical Union, v. 61, p. 1152.

Siegel, D.I., and Ericson, D.W., 1980, Hydrology and water quality of the copper-nickel study region, northeasterr Minnesota: U.S. Geological Survey Water-Resources Investigations Report 80-739, 87 p.

Siegel. D.I., and Winter, T.C., 1980, Hydrologic setting of Williams Lake, Hubbard County, Minnesota: U.S. Geolcgical Survey Open-File Report 80-403, 56 p.

Soukup. W.G., 1980, Ground-water appraisal in northwestern Big Stone County, west-central Minnesota: U.S. Geological Survey Open-File Report 80-568, 41 p.

Tomes, L.H., 1980, Preimpoundment water quality of the Wild Rice River, Norman County, Minnesota: U.S. Geological Survey Water-Resources Investigations Report 80-79, 36 p.

Tornes, L.H., and Have, M.R., 1980, Water quality of four lakes in Lakeville, Minnesota: U.S. Geological Survey Water-Resources Investigations Report 80-66, 51 p.

\section{1}

Adolphson, D.G., Ruhl, J.F., and Wolf, R.J., 1981, Designation of principal water-supply aquifers in Minnesota: U.S. Geological Survey Water-Resources Investigations Report 81-51, 19 p.

Diedrich, M.M., and Jannis, J.A., 1981, Status of projects in Minnesota, fiscal year 1981: U.S. Geological Survey, $58 \mathrm{p}$.

Groschen, G.E., and Alexander, E.C., Jr., 1981, Geochemistry of Williams Lake, Hubbard County, Minnesota [abs ]: EOS, Transactions, American Geophysical Union, v. 63, no. 33, p. 613.

Have, M.R., Payne, G.A., and Ayers, M.A., 1981, Water quality of Alimagnet, Farquar, and Long Lakes in Apple Valley, Minnesota: U.S. Geological Survey Water-Resources Investigations Report 81-40, 38 p.

Horn, M.A., 1981, Data for water resources management in Minnesota, in Allee, D.J., Dworsky, L.B., and North, R.M., eds., Unified River Basin Management-Stage II, American Water Resources Association Symposiun, Atlanta, Georgia, October 4-8, 1981, Proceedings: American Water Resources Association, p. 429-441.

Hubbell, D.W., Stevens, H.H., Jr., Skinner, J.V., and Beverage, J.P., 1981, Recent refinements in calibrating bed-load samplers, in Water Forum '81, San Francisco, California, August 10-14, 1981, Proceedings: American Society of Civil Engineers, v. 1, p. 128-140.

Hult, M.F., and Schoenberg, M.E., 1981, Preliminary evaluation of ground-water contamination by coal-tar derivatives, St. Louis Park area, Minnesota: U.S. Geological Survey Water-Resources Investigations Report 81$72,53 \mathrm{p}$.

LaBaugh, J.W., Groschen, G.E., and Winter, T.C., 1981, Limnological and geochemical survey of Williams Lake, Hubbard County, Minnesota: U.S. Geological Survey Water-Resources Investigations Report 81-41, 38 p. 
Miller, R.T., 1981, Hydrologic data for the Pelican River Sand-Plain aquifer, western Minnesota: U.S. Geological Survey Open-File Report 80-695, 86 p.

Schoenberg. M.E., 1981, Evaluation of geohydrologic data using a ground-water-flow model of the Twin Cities metropolitan area, Minnesota [abs.]: Annual Meeting, 94th, Cincinnati, Ohio, November 2-5, 1981, Proceedings: Geological Society of America, p. 548.

1981, Seasonal versus long-term potentiometric-level variations in the Mount Simon-Hinckley and Prairie du Chien-Jordan aquifers, Twin Cities metropolitan area [abs.]: Midwest Meeting of the American Geophysical Union, Minneapolis, Minnesota, September 17-18, 1981, Proceedings: American Geophysical Union, p. 613.

Schoenberg, M.E., and Guswa, J.H., 1981, Evaluating ground-water data by a flow model of the Twin Cities metropolitan area, Minnesota [abs.]: Midwest Meeting of the American Geophysical Union, Minneapolis, Minnesota, September 17-18, 1981, Proceedings: American Geophysical Union, p. 8.

Siegel, D.I., 1981, Effect of snowmelt on the water quality of Filson Creek and Omaday Lake, northeastern Minnesota: U.S. Geological Survey Water-Resources Investigations Report 81-66, 81 p.

1981. The effect of snow melt on water quality of Filson Creek and Omaday Lake, northeastern Minnesota: Water Resources Research, v. 17, no. 1, p. 238-242.

1981, Hydrogeologic setting of the glacial Lake Agassiz peatlands, northern Minnesota: U.S. Geological Survey Water-Resources Investigations Report 81-24, 30 p.

Siegel, D.I., Kontis, A.L., and Mandle, R.J., 1981, The chemical evolution of water quality in the CambrianOrdovician aquifer, north-central United States 1981 [abs.]: Midwest Meeting of the American Geophysical Union, Minneapolis, Minnesota, September 17-18, 1981, Proceedings: American Geophysical Union, p. 8.

Skinner, J.V., and Beverage, J.P., 1981, Test and design of automatic fluvial suspended-sediment samplers: Federal Inter-Agency Sedimentation Project. $53 \mathrm{p}$.

Tornes, L.H., 1981, Quality of surface water before implementation of a flood-control project in Chaska, Minnesota: U.S. Geological Survey Water-Resources Investigations Report 81-83, $53 \mathrm{p}$.

Wolf, R.J., 1981, Hydrogeology of the Buffalo aquifer, Clay and Wilkin Counties, west-central Minnesota: U.S. Geological Survey Water-Resources Investigations Report 81-4, 83 p.

\section{2}

Ehrlich, G.G., Georlitz, D.F., Godsy, E.M., and Hult, M.F., 1982, Degradation of phenolic contaminants in ground water by anaerobic bacteria—St. Louis Park, Minnesota: Ground Water, v. 20, no. 6, p. 703-710.

Groschen, G.E., and Alexander, E.C., Jr., 1982, Geochemistry of Williams Lake, Hubbard County, Minnesota [abs.]: EOS, Transactions, American Geophysical Union, v. 63, no. 33., p. 613.

Gunard, K.T., and Smith, C.J., 1982, Small stream flood investigations in Minnesota, October 1958 to September 1980: U.S. Geological Survey Open-File Report 82-433, 221 p.

Guswa, J.H., Siegel, D.I., and Gillies, D.C., 1982, Preliminary evaluation of the ground-water-flow system in the Twin Cities metropolitan area, Minnesota: U.S. Geological Survey Water-Resources Investigations Report 82-44, 65 p.

Hein, M.D., 1982, Status of water-resources projects in Minnesota fiscal year 1982: U.S. Geological Survey, 61 p.

Miller, R.T., 1982, Appraisal of the Pelican River Sand-Plain aquifer, western Minnesota: U.S. Geological Survey Open-File Report 82-347, 44 p. 
Myette, C.F., 1982, Baseline water-quality data for sand-plain aquifers in Hubbard, Morrison, Otter Tail, and Wadeาa Counties, Minnesota: U.S. Geological Survey Open-File Report 82-909, 112 p.

Payne, G.A., Ayers, M.A., and Brown, R.G., 1982, Quality of runoff from small watersheds in the Twin Cities metropolitan area, Minnesota-Hydrologic data for 1980: U.S. Geological Survey Open-File Report 82-504, $289 \mathrm{p}$.

Ruhl, J.F., Wolf, R.J., and Adolphson, D.G., 1982, Hydrogeologic and water-quality characteristics of the IrontonGalesville aquifer, southeast Minnesota: U.S. Geological Survey Water-Resources Investigations Report 824080, 2 sheets.

Schoenberg, M.E., 1982, Seasonal versus long-term variations in potentiometric levels in the Mount Simon-Hinckl-y and Prairie du Chien-Jordan aquifers, Twin Cities metropolitan area, Minnesota [abs.]: EOS, Transactions, American Geophysical Union, v. 63, no. 33, p. 613.

Schoenberg, M.E., and Guswa, J.H., 1982, Evaluating ground-water data by a flow model of the Twin Cities metropolitan Area, Minnesota [abs.]: EOS, Transactions, American Geophysical Union, v. 63, no. 33, p. 612.

Siegel, D.I., Kontis, A.L., and Mandle, R.J., 1982, The chemical evolution of water quality in the CambrianOrdovician aquifer, north-central United States [abs.]: EOS, Transactions, American Geophysical Union, v. 63, no. 33, p. 612 .

Siegel, D.I., and Mandle, R.J., 1982, Geochemical evidence for Pleistocene glacial meltwater recharge to the Cambrian-Ordovician aquifer in the north-central United States [abs.]: Geological Society of America Abstracts with Programs 1982, v. 14, no.5, p. 288.

Skinner, J.V., 1982, A fluid density gage for measuring suspended-sediment concentration, Part A. Gage response to steady-state and transient conditions: Federal Inter-Agency Sedimentation Project Report X, 125 p.

Skinner, J.V., and Benson, D.A., 1982, Services provided by the Federal Inter-Agency Sedimentation Project: Fede-al Inter-Agency Sedimentation Project, $2 \mathrm{p}$.

Winterstein, T.A., 1982, Annotated report and data inventory for the Mississippi and Minnesota Rivers, MinneapolisSt. Paul metropolitan area: U.S. Geological Survey Open-File Report 82-869, 99 p.

Woodward, D.G., 1982, Effects of the Mississippi River system on ground-water flow in southeastern Minnesota [abs.]: Annual Meeting of Mississippi River Research Consortium, 15th, LaCrosse, Wisconsin, April 14-16, 1982, Proceedings: Mississippi River Research Consortium, p. 38.

Woodward, D.G., Delin, G.N., 1982, Potentiomentric surface of regional aquifers in the Hollandale Embayment, southeastern Minnesota [abs.]: EOS, Transactions, American Geophysical Union, v. 63, no. 33, p. 612.

\section{3}

Adolphson, D.G., 1983, Availability and chemical quality of water from surficial aquifers in southwest Minnesots: U.S. Geological Survey Water-Resources Investigations Report 83-4030, 37 p.

Brown, R.G., 1983, Atmospheric deposition of selected chemicals and their effect on nonpoint-source pollution in the Twin Cities metropolitan area, Minnesota: U.S. Geological Survey Water-Resources Investigations Report 834195, $24 \mathrm{p}$.

Czarnecki, J.B., 1983, Fortran computer programs to plot and process aquifer pressure and temperature data: U.S. Geological Survey Water-Resources Investigations Report 83-4051, 50 p.

Horn, M.A., 1983, Ground-water-use trends in the Twin Cities metropolitan area, Minnesota 1880-1980: U.S. Geological Survey Water-Resources Investigations Report 83-4033, 37 p. 
Hubbell, D.W., Stevens, H.H., Jr., Skinner, J.V., and Beverage, J.P., 1983, New approach to calibrating bed-load samplers: Journal of Hydraulic Engineering, v. III, no. 4. p. 677-694.

Jannis, J.A., 1983, Status of water-resources projects in Minnesota, fiscal year 1983: U.S. Geological Survey, 74 p.

Nelson, Luanne, and Brown, R.G.. 1983, Streamflow and water-quality data for wetland inflows and outflows in the Twin Cities metropolitan area, Minnesota, 1981-82: U.S. Geological Survey Open-File Report 83-543, 182 p.

Payne, G.A., 1983, Streamflow and suspended-sediment transport in Garvin Brook. Winona County, southeastern Minnesota - Hydrologic data for 1982: U.S. Geological Survey Open-File Report 83-212, 22 p.

Pereira, W.E., Rostad, C.E., Garbarino, J.R., and Hult, M.F., 1983, Ground-water contamination by organic bases derived from coal-tar wastes: Environmental Toxicology and Chemistry, v. 2, p. 283-294.

Ruhl, J.F., and Wolf, R.J., 1983, Hydrogeologic and water-quality characteristics of the St. Peter aquifer, southeast Minnesota: U.S. Geological Survey Water-Resources Investigations Report 83-4200, 2 sheets.

Ruhl, J.F., Wolf, R.J., and Adolphson, D.G., 1983, Hydrogeologic and water-quality characteristics of the Prairie du Chien-Jordan aquifer, southeast Minnesota: U.S. Geological Survey Water-Resources Investigations Report 834045, 2 sheets.

U.S. Geological Survey, 1983, Quality assurance plan for the ground-water program of the Minnesota District: Unpublished report on file with U.S. Geological Survey in Mounds View, Minnesota, $40 \mathrm{p}$.

Wershaw, R.L., and Fishman, M.J., 1983, Methods for the determination of organic substances in water and fluvial sediments: U.S. Gcological Survey Techniques of Water-Resources Investigations, book 5, chap. A3, 173 p.

Wolf, R.J., Ruhl, J.F., and Adolphson, D.G., 1983, Hydrogeologic and water-quality characteristics of the Mount Simon-Hinckley aquifer, southeast Minnesota: U.S. Geological Survey Water-Resources Investigations Report 83-4031, 2 sheets.

\section{4}

Anderson, H.W., Jr., and Ruhl, J.F., 1984, Geohydrology and hydrochemistry of aquifers in Cretaceous rocks, Minnesota, in Geohydrology of the Dakota aquifer, C.V. Theis Conferences on Geohydrology, 1st, Lincoln, Nebraska, October 5-6, 1982, Proceedings: National Water Well Association, p. 27-37.

Brown, R.G., 1984, Effects of an urban wetland on sediment and nutrient loads in runoff: Wetlands, v. 4, p. 147-158.

1984, Hydrologic effects of impoundments in Sherburne National Wildlife Refuge, Minnesota: U.S. Geological Survey Water-Resources Investigations Report 84-4175, 20 p.

1984, Precipitation and streamflow data Collections techniques, in Understanding Watershed and Lake Management Conference, Bloomington, Minnesota, March 23, 1984 [Proceedings], p. 18-29.

-1984, Relationship between quantity and quality of storm runoff and various watershed, characteristics in Minnesota, USA, in International Conference on Urban Storm Drainage, 3rd, Goteborg, Sweden, June 4-8, 1984 [Proceedings], p. 791-799.

Delin, G.N., and Woodward, D.G., 1984, Hydrogeologic setting and potentiometric surfaces of regional aquifers in the Hollandale Embayment, southeastern Minnesota, 1970-80: U.S. Geological Survey Water-Supply Paper 2219, p. 56.

Hatch, J.R., and Morey, G.B., 1984, Hydrocarbon source rock evaluation-Solo Church Formation (middle Proterozoic, Keeweenawan Supergroup), southeastern Minnesota: U.S. Geological Survey Open-File Report 84$554,17 \mathrm{p}$. 
Horn, M.A., 1984, Annual ground-water use in the Twin Cities metropolitan area, Minnesota 1970-79: U.S. Geological Survey Open-File Report 84-577, 130 p.

Hult, M.F.. 1984, Assessment of ground-water contamination by coal-tar derivatives, St. Louis Park area Minnesota: U.S. Geological Survey Open-File Report 84-867, 57 p.

Hult, M.F., 1984, Ground-water contamination by crude oil at the Bemidji, Minnesota research site-An introduction, in Hult, M.F., ed., Ground-water contamination by crude oil at the Bemidji, Minnesota research site-U.S. Geological Survey toxic waste ground-water contamination study: U.S. Geological Survey Wate-Resources Investigations Report 84-4188, p. 1-15.

Hult, M.F., ed., 1984. Ground-water contamination by crude oil at the Bemidji, Minnesota research site-U.S. Geological Survey toxic waste-ground-water contamination study: U.S. Geological Survey Water-Resources Investigations Report 84-4188, $107 \mathrm{p}$.

Hult, M.F., and Schoenberg, M.E., 1984, Preliminary evaluation of ground-water contamination by coal-tar derivatives, St. Louis Park area, Minnesota: U.S. Geological Survey Water-Supply Paper 2211, 53 p.

Jannis, J.A., 1984, Status of projects in Minnesota, fiscal year 1984: U.S. Geological Survey Open-File Report, 84 p.

Miller, R.T., 1984, Determination of hydraulic conductivity in three dimensions and its relation to dispersivity in ground-water contamination by crude oil at the Bemidji, Minnesota research site, in Hult, M.F., ed., Groundwater contamination by crude oil at the Bemidji, Minnesota research site-U.S. Geological Survey toxic waste ground-water contamination study: U.S. Geological Survey Water-Resources Investigations Report 84-4188, p. 49-64.

1984, Preliminary modeling of an aquifer thermal-energy storage system: U.S. Geological Survey Open-File Report 84-811, $47 \mathrm{p}$.

Myette, C.F., 1984, Appraisal of water from surficial-outwash aquifers in Todd County and parts of Cass and Morrisnn Counties, central Minnesota: U.S. Geological Survey Water-Resources Investigations Report 83-4156, 43 p.

1984, Ground-water-quality appraisal of sand-plain aquifers in Hubbard, Morrison, Otter Tail, and Wadena Counties, Minnesota: U.S. Geological Survey Water-Resources Investigations Report 84-4080, 49 p.

Ruhl, J.F., and Wolf, R.J., 1984, Hydrogeologic and water quality characteristics of the Upper Carbonate aquifer, southeastern Minnesota: U.S. Geological Survey Water-Resources Investigations Report 84-4150, 2 sheets.

Schoenberg, M.E., 1984, Water levels and water-level changes in the Prairie du Chien-Jordan and Mount SimonHinckley aquifers, Twin Cities metropolitan area, Minnesota, 1971-80: U.S. Geological Survey WaterResources Investigations Report 83-4237, 23 p.

Skinner, J.V., 1984, Measuring the surface area of sediment particles in measurement and analysis of sediment loats in streams: Federal Inter-Agency Sedimentation Project Report FF, 28 p.

Soukup, W.G., Gillies, D.C., and Myette, C.F., 1984, Appraisal of the surficial aquifers in the Pomme de Terre ant Chippewa River Valleys, western Minnesota: U.S. Geological Survey Water-Resources Investigations Report 84-4086, $63 \mathrm{p}$.

Sturrock, A.M., Rosenberry, D.O., Engelbrecht, L.G., Gothard, W.A., and Winter, T.C., 1984, Climatic data from Williams Lake, Hubbard County, Minnesota, 1983: U.S. Geological Survey Open-File Report 84-247, 41 p.

U.S. Geological Survey, 1984, Ground-water contamination by crude petroleum at the Bemidji, Minnesota research site-Compilation of resource documents and project plan March 1984, variously paged.

Winter, T.C., 1984, Reply to comment by M.P. Anderson, and J.A. Munter on, "the interaction of lakes with variak'ly saturated porous media,": Water Resources Research, v. 20, no. 8, p. 1166. 
Woodward, D.G., 1984, Areal lithologic changes in bedrock aquifers in southeastern Minnesota as determined from natural-gamma borehole logs methods, in Nielsen, D.M., and Curl, Mary, eds., Conference on Surface and Borehole Geophysical Investigations, San Antonio, Texas, February 7-9, 1984, Proceedings: National Water Well Association/Environmental Protection Agency, p. 788-800.

1984, Minnesota ground water resources, in U.S. Geological Survey National Water Summary 1984: U.S. Geological Survey Water-Supply Paper 2275, p. 261-268.

1984, The study of buried drift aquifers in Minnesota by seismic geophysical methods: U.S. Geological Survey Open-File Report, 2 p.

Woodward, D.G., and Anderson, H.W., Jr., 1984, Hydrogeologic and water-quality characteristics of the Cretaceous aquifer, southwestern Minnesota: U.S. Geological Survey Water-Resources Investigations Report 84-4153, 2 sheets.

\section{5}

Anderson, H.W., Jr., 1985, Impact of agriculture on quality of water in surficial sand-plain aquifers in central Minnesota [abs.]: Annual Midwest Ground Water Conference, 30th, St. Paul, Minnesota, October 23-25, 1985 [Proceedings], p. 9.

Arntson, A.D., and Tornes, L.H., 1985, Rainfall-runoff relationship and water-quality assessment of Coon Creek watershed, Anoka County, Minnesota: U.S. Geological Survey Water-Resources Investigations Report 84-4013, $97 \mathrm{p}$.

Ayers, M.A., Brown, R.G., and Oberts, G.L., 1985, Runoff and chemical loading in small watersheds in the Twin Cities metropolitan area, Minnesota: U.S. Geological Survey Water-Resources Investigations Report 85-4122, $35 \mathrm{p}$.

Brown, R.G., 1985, Effects of wetlands on quality of runoff entering lakes in the Twin Cities metropolitan area, Minnesota: U.S. Geological Survey Water-Resources Investigations Report 85-4170, 32 p.

1985, Errors associated with estimating ground-water flow and phosphorus flux components in hydrologic and phosphorous budgets of lakes [abs.]: Annual Midwest Ground Water Conference, 30th, St. Paul, Minnesota, October 23-25, 1985 [Proceedings], p. 3.

1985, Hydrologic factors affecting lake-level fluctuations in Big Marine Lake, Washington County, Minnesota: U.S. Geological Survey Water-Resources Investigations Report 85-4176, 23 p.

Brown, R.G., and Stark, J.R., and Patterson, G.L., 1985, Ground-water and surface-water interactions in Minnesota and Wisconsin wetlands, in Hook, D.D., McKee, W.H., Jr., Smith, H.K., Gregory, J., Burrell, V.G., Jr., DeVee M.,R., Sojka, R.E., Gilberts, S., Banks, R., Stolzy, L.H., Brooks, C., Matthews, T.D., and Shear, T.H., The ecology and management of wetlands: Portland, Oregon, Timber Press, p. 176-180.

Delin, G.N., 1985, Confined-drift aquifers studied near the Pomme de Terre and Chippewa Rivers, west-central Minnesota: U.S. Geological Survey Open-File Report, 2 p.

Gunard, K.T., 1985, Minnesota surface-water resources, in Woody, D.W., Chase, E.B., and Aronson, D.A., compilers, National Water Summary 1985: U.S. Geological Survey Water-Supply Paper 2300, p. 285-294.

Miller. R.T.. 1985, Preliminary modeling of an aquifer thermal-energy storage system, in Subitsky, Seymour, ed., Selected papers in hydrologic sciences: U.S. Geological Survey Water-Supply Paper 2270, p. 1-19.

Myette, C.F., 1985, Hydrogeology of sand-plain aquifers in Carlton, Kanabec, and Pine Counties, east-central Minnesota: U.S. Geological Survey Water-Resources Investigations Report 85-4334, 66 p. 
Rostad, C.E., Pereira, W.E., and Hult, M.F., 1985, Partitioning studies of coal-tar constituents in a two-phase contaminated ground-water system: Chemosphere, v. 14, no. 8, p. 1023-1036.

Stark, J.R., and Hult, M.F.,1985, Ground-water flow in the Prairie du Chien-Jordan aquifer related to contamination by coal-tar derivatives, St. Louis Park, Minnesota: U.S. Geological Survey Water-Resources Investigations Report 85-4087, $57 \mathrm{p}$.

1985, Simulation of ground-water flow in the Prairie du Chien-Jordan aquifer and relation to ground-water contamination by coal-tar derivatives, St. Louis Park, Minnesota [abs.]: Annual Midwest Ground Water Conference, 30th, St. Paul, Minnesota, October 23-25, 1985 [Proceedings], p. 14.

1985, Simulation of ground-water flow in the Prairie du Chien-Jordan aquifer and relation to ground-water contamination by coal-tar derivatives, St. Louis Park, Minnesota: National Water Well Association Confererse Exposition, Worthington, Ohio, August 19-20, 1985, Proceedings: National Water Well Association, p. 290-310.

Stoner, J.D., 1985, Simulation of ground-water flow near a former wood-treating waste site in Fridley, MinnesotaPart II. A practical application of an analytic-element model [abs.]: Annual Midwest Ground Water Conferen?e, 30th, St. Paul, Minnesota, October 23-25, 1985 [Proceedings], p. 18.

Taylor, W.W., LaBaugh, J.W., Freeberg, M.H., and Dowling, D.C., 1985, Fishery survey and related limnological conditions of Williams Lake, Hubbard County, Minnesota: U.S. Geological Survey Water-Resources Investigations Report 84-4145, 25 p.

Tomes, L.H., 1985, Suspended sediment in Minnesota streams: U.S. Geological Survey Water-Resources Investigations Report 85-4312, 33 p.

Trotta, L.C., 1985, The potential for contamination of ground water based on hydrogeology-A geographic information system application [abs.]: Annual Midwest Ground Water Conference, 30th, St. Paul, Minnesot', October 23-25, 1985 [Proceedings], p. 19.

Woodward, D.G., 1985, Seismic-refraction study of suspected drift-filled bedrock valleys in Ramsey County, Minnesota: U.S. Geological Survey Water-Resources Investigations Report 85-4107, 20 p.

-1985, Trends in municipal-well installations and aquifer utilization in southeastern Minnesota, 1880-1980: U.S. Geological Survey Water-Resources Investigations Report 83-4222, 99 p.

\section{6}

Anderson, H.W., Jr., 1986, Hydrogeologic and water-quality characteristics of crystalline-rock aquifers of Archern and Proterozoic age, Minnesota: U.S. Geological Survey Water-Resources Investigations Report 86-4033, 3 sheets.

Baedecker, M.J., Eganhouse, R.P., Miller, R.T., and Hult, M.F., 1986, The composition and fate of hydrocarbons in a glacial aquifer [abs:]: Symposium on Scientific Advances in Geology and Hydrology from Studies of Contaminant Plumes, San Antonio, Texas, November 1986, Proceedings: Geological Society of America, v.18, no. 6, p. 531 .

Beverage, J.P., and Futrell, J.C., 1986, Comparison of flume and towing methods for verifying the calibration of a suspended-sediment sampler: U.S. Geological Survey Water-Resources Investigations Report 86-4193, 11 F.

Brown, R.G., 1986, Errors in estimating ground-water components of hydrologic and phosphorus budgets of lakes in Subitzky, Seymour, ed., Selected papers in hydrologic sciences 1986: U.S. Geological Survey Water-Supply Paper 2310, p. 53-64. 
Brown, R.G., Patterson, G.L., and Stark, J.R., 1986, Ground-water and surface-water interaction in wetlands-Comparisons and contrasts [abs.]: Wisconsin Section Annual Meeting, Wisconsin Dells, Wisconsin. April 3-4, 1986, Proceedings: American Water Resources Association, p. 1.

Delin, G.N., 1986, Confined-drift aquifers in Minnesota: U.S. Geological Survey Open-File Report 86-240, 2 p.

1986, Hydrogeology of confined-drift aquifers in part of west-central Minnesota [abs.]: Annual Meeting NorthCentral Section of Geological Society of America, 20th, Kent, Ohio, April 24-25, 1986, Proceedings: Geological Society of America, p. 286.

-1986, Hydrogeology of confined-drift aquifers near the Pomme de Terre and Chippewa Rivers, western Minnesota: U.S. Geological Survey Open-File Report 86-4098, 90 p.

Horn, M.A., 1986, Development of a water-use data system in Minnesota: U.S. Geological Survey Water-Resources Investigations Report 85-4306, $59 \mathrm{p}$.

Hult, M.F., 1986, Transport and oxidation of hydrocarbon vapors in a shallow aquifer [abs.]: EOS, Transactions, American Geophysical Union, v. 67, no. 16, p. 279.

Hult, M.F., Chang, F.H., and Pfannkuch, H.O., 1986, Microbial oxidation of petroleum vapors in the unsaturated zone, in Chapman Conference on Microbial Processes in the Transport, Fate and In-situ Treatment of Subsurface Contaminants, Snowbird, Utah, October 1-3, 1986: American Geophysical Union Chapman Meeting Abstracts, p. 23-24.

Jannis, J.A., 1986, Water-resources activities of the U.S. Geological Survey in Minnesota, fiscal year 1985: U.S. Geological Survey Open-File Report 86-133, 83 p.

Miller, R.T., 1986, Thermal-energy storage in a confined sandstone aquifer at St. Paul, Minnesota, in Carter, L.M.H., ed., U.S. Geological Survey Research on Energy Resources-1986: U.S. Geological Survey Circular 974, p. 4142.

Miller, R.T., and Voss, C.I., 1986, Finite difference grid for a doublet well in an anisotropic aquifer: Ground Water, v. 24 , no. 4 , p. $490-496$.

Ruhl, J.F., and Adolphson, D.G., 1986, Hydrogeologic and water-quality characteristics of the Red River, Winnipeg aquifer, northwestern Minnesota: U.S. Geological Survey Water-Resources Investigations Report 84-4111, 2 sheets.

Skinner, J.V., 1986, Measurement of scour depth near bridge piers: U.S. Geological Survey Water-Resources Investigations Report 85-4106, $33 \mathrm{p}$.

1986, Sampling suspended sediment in ice-covered rivers: International Northern Research Basins Symposium, 6th, Michigan Technology University, January 26-30, 1986 [Proceedings], p. 105-108.

Skinner, J.V., and Beverage, J.P., 1986, Continuous measurement of suspended-sediment concentration: Federal InterAgency Sedimentation Conference, 4th, Las Vegas, Nevada, March 24-27, 1986, Proceedings: Federal InterAgency Sedimentation Project, p. 1.29 to 1.39 .

Sturrock, A.M., Rosenberry, D.O., Scarborough, J.L., and Winter, T.C., 1986, Climatic data for Williams Lake, Hubbard County, Minnesota, 1984: U.S. Geological Survey Open-File Report 86-64, 62 p.

Winterstein, T.A., 1986, Water-resources activities of the U.S. Geological Survey in the Red River Valley, Minnesota fiscal year 1986: U.S. Geological Survey, $32 \mathrm{p}$.

Winterstein, T.A., and Stefan, H.G., 1986, Effects of nozzle orientation on sediment sampling: Federal Inter-Agency Sedimentation Conference, 4th, Las Vegas, Nevada, March 24-27, 1986, Proceedings: Federal Inter-Agency Sedimentation Project, p. 1.20-1.28. 
Woodward, D.G., 1986, Hydrogeologic framework and properties of regional aquifers in the Hollandale Embayment, southeastern Minnesota: U.S. Geological Survey Hydrologic Investigations Atlas HA-677, 2 sheets, scales $1: 1,000,000$ and $1: 2,000,000$.

\section{7}

Albin, D.R., 1987, Minnesota ground-water quality: U.S. Geological Survey Open-File Report 87-733, 10 p.

Albin, D.R., and Breummen, L.B., 1987, Minnesota ground-water quality, in Moody, D.W., Carr, Jerry, Chase, E.P., and Paulson, R.W., compilers, National Water Summary 1986: U.S. Geological Survey Water-Supply Paper 2325, p. 313-320.

Arntson, A.D., and Lorenz, D.L., 1987, Low-flow frequency characteristics for continuous-record streamflow staticns in Minnesota: U.S. Geological Survey Water-Resources Investigations Report 86-4353, 15 p.

Baehr, A.L., and Hult, M.F., 1987, Mathematical modeling of hydrocarbon and oxygen transport coupled with microbial degradation in the unsaturated zone [abs.], in Franks, B.J., ed., U.S. Geological Survey program on toxic waste ground-water contamination-Proceedings of the third technical meeting, Pensacola, Florida, March 23-27, 1987: U.S. Geological Survey Open-File Report 87-109, p. C-27-C28.

Brown, R.G., 1987, Effects of wetland channelization of storm runoff in Lambert Creek, Ramsey County, Minneso+a: National Wetlands Symposium of Wetland Hydrology, Chicago, Illinois, September 16-18, 1987 [Proceedings], p. 130-136.

Chang, Fu-Hsian, Hult, M.F., and Noben, N.N., 1987, Quantitative studies of biodegradation of petroleum and some model hydrocarbons in ground water and sediment environments, in Fairchild, D.M., ed., Ground-water quality and agricultural practices: Chelsea, Michigan, Lewis Publishers, p. 295-318.

Delin, G.N., 1987, Evaluation of availability of water from drift aquifers near the Pomme de Terre and Chippewa Rivers, western Minnesota: U.S. Geological Survey Water-Resources Investigations Report 86-4321, 53 p.

1987, Ground-water quality in a complex system of glacial-drift aquifers in west-central Minnesota [abs.], in Zaporozec, A., ed., Annual Midwest Ground Water Conference, 32nd, Madison, Wisconsin, October 28-30, 1987 [Proceedings].

Have, M.R., and Tornes, L.H., 1987, Water quality data for Orwell Reservoir and Otter Tail River near Fergus Falls, Minnesota: U.S. Geological Survey Open-File Report 87-537, 48 p.

Hubbell, D.W., Stevens, H.H., Jr., Skinner, J.V., and Beverage, J.P., 1987, Laboratory data on coarse-sediment transport for bed-load-sampler calibrations: U.S. Geological Survey Water-Supply Paper 2299, 30 p.

Hult, M.F., 1987, Measurement of hydrocarbon vapors and degradation products in the unsaturated zone [abs.]: EC 5 . Transactions, American Geophysical Union, v. 68, no. 16, p. 327.

1987, Microbial oxidation of petroleum vapors in the unsaturated zone [abs.] in Franks, B.J., ed., U.S. Geological Survey program on toxic waste ground water contamination-Proceedings of the third technical meeting, Pensacola, Florida, March 23-27, 1987: U.S. Geological Survey Open-File Report 87-109 p. C25-C26.

1987, Movement and fate of crude-oil in contaminants in the subsurface environment at Bemidji, Minneso ${ }^{+}$, Chapter C, in Frank, B.J., ed., U.S. Geological Survey Program on toxic waste-ground-water contaminatiorProceedings of the third technical meeting, Pensacola, Florida, March 23-27, 1987: U.S. Geological Survey Open-File Report 87-109, p. C3-C4.

Lorenz, D.L., and Stark, J.R., 1987, Evaluation of gradient-control options for contaminated ground water in the $5 t$ Peter aquifer, St. Louis Park, Minnesota [abs.], in Zaporozec, A., ed., Annual Midwest Ground Water Conference, 32nd, Madison, Wisconsin, October 28-30, 1987 [Proceedings]. 
Miller, R.T., 1987, Effects of local hydraulic discontinuities on the transport of crude oil residuals in ground water, Bemidji, Minnesota, in Franks, B.J., ed., U.S. Geological Survey program on toxic waste-ground-water contamination-Proceedings of the third technical meeting, Pensacola, Florida, March 23-27, 1987: U.S. Geological Survey Open-File Report 87-109, p. C9.

Ruhl, J.F., 1987, Hydrogeologic and water-quality characteristics of glacial-drift aquifers in Minnesota: U.S. Geological Survey Water-Resources Investigations Report 87-4224, 3 sheets.

1987, Water-quality characteristics in glacial-drift aquifers in Minnesota [abs.]: Annual Meeting of Geological Society of America, North Central Section, 21 st, St. Paul, Minnesota, April 30-May 1, 1987, Proceedings: Geological Society of America, p. 241.

Schoenberg, M.E., 1987, Effects of future ground-water withdrawals on water levels in the Twin Cities aquifer system, Minnesota [abs.]: Annual Meeting of the Geological Society of America, North Central Section, 21st, St. Paul, Minnesota, April 30-May 1, 1987, Proceedings: Geological Society of America, p. 242-243.

-1987, Relation between predevelopment hydraulic heads and present-day water quality in the Twin Cities aquifer system, Minnesota [abs.], in Zaporozec, A, ed., Annual Midwest Ground Water Conference, 32nd, Madison, Wisconsin, October 28-30, 1987 [Proceedings].

Siegel, D.I., 1987, Geochemical facies and mineral dissolution, Bemidji, Minnesota research site, in Franks, B.J., ed., U.S. Geological Survey program on toxic waste-ground-water contamination-Proceedings of the third technical meeting, Pensacola, Florida, March 23-27, 1987: U.S. Geological Survey Open-File Report 87-109, p. C13-C15.

Skinner, J.V., 1987, Progress report on temperature effects in vibrational type sediment-concentration gages: Federal Inter-Agency Sedimentation Project Report II, 48 p.

Stark, J.R., and Brown, R.G., 1987, Hydrologic interactions in a wetland in Minnesota and Wisconsin [abs.]: Annual Meeting of the Geological Society of America, North Central Section, 21st, St. Paul, Minnesota, April 30-May 1, 1987, Proceedings: Geological Society of America, p. 247-248.

1987, Hydrology and water quality of a wetland used to receive wastewater effluent, St. Joseph, Minnesota, in National Wetland Symposium, Chicago, Illinois, September 16-18, 1987, Proceedings: Association of State Wetland Managers, Inc., p. 197-204.

Stark, J.R., Strudell, J.D., Bloomgren, P.A., and Eger, Paul, 1987, Ground-water and soil contamination near two pesticide-burial sites in Minnesota: U.S. Geological Survey Water-Resources Investigations Report 87-41 15, 48 p.

Stoner, J.D., and Streitz, A.R., 1987, Locating confined aquifers in glacial drift with seismic reflection methods, western Minnesota [abs.]: Annual Meeting of the Geological Society of America, North Central Section, 21 st, St. Paul, Minnesota, April 30-May 1, 1987, Proceedings: Geological Society of America, p. 248.

Sturrock, A.M., Rosenberry, D.O., and Winter, T.C., 1987, Climatic data for Williams Lake, Hubbard County, Minnesota, 1985: U.S. Geological Survey Open-File Report 86-607, 40 p.

Trotta, L.C., 1987, Ground water withdrawals in Minnesota [abs.], in Zaporozec, A., ed., Annual Midwest Ground Water Conference, 32nd, Madison, Wisconsin, October 28-30, 1987 [Proceedings].

1988

Albin, D.R., 1988, U.S. Geological Survey ground-water studies in Minnesota: U.S. Geological Survey Open-File Report 88-127, 2 p. 
Chang, Fu-Hsian, Noben, N.N., Brend, Daniel, and Hult, M.F., 1988, Microbial degradation of crude oil and some model hydrocarbons, in Ragone, S.E., ed., U.S. Geological Survey Program on toxic waste - ground-water contamination-Proceedings of the second technical meeting, Cape Cod, Massachusetts, October 21-25, 19\& $\varsigma$ : U.S. Geological Surve; Open-File Report 86-481, p. C33-C42.

Hult, M.F., and Grabbe, R.R., 1988, Distribution of gases and hydrocarbon vapors in the unsaturated zone, in Ragone, S.E., ed., U.S. Geological Survey program on toxic waste-ground-water contamination-Proceedings of th : second technical meeting, Cape Cod, Massachusetts, October 21-25, 1985: U.S. Geological Survey Open-File Report 86-481, p. C21-C25.

Jaques, J.E., and Lorenz, D.L., 1988, Techniques for estimating the magnitude an frequency of floods in Minneso'a: U.S. Geological Survey Water-Resources Investigations Report 87-4170, 48 p.

Miller, R.T., 1988, Hydrogeology and preliminary regional flow modeling at the Bemidji, Minnesota research site, in Ragone, S.E., ed., U.S. Geological Survey program on toxic waste - ground-water contamination-Proceedings of the second technical meeting Cape Cod, Massachusetts, October 21-25, 1985: U.S. Geological Survey OpenFile Report 86-481, p. C11-C16.

Pfannkuch, H.O., Nourse, S.M., and Hult, M.F., 1988, Mass transfer at the alkane water interface in laboratory columns of porous media, in Ragone, S.E., ed., U.S. Geological Survey program on toxic waste-ground water contamination-Proceedings of the second technical meeting, Cape Cod, Massachusetts, October 21-25, $19 \varepsilon^{5}$ : U.S. Geological Survey Open-File Report 86-481, p. C29-C32.

Rosenberry, D.O., Sturrock, A.M., Scarborough, J.L., and Winter, T.C., 1988, Climatic data for Williams Lake, Hubbard County, Minnesota: U.S. Geological Survey Open-File Report 88-89, 42 p.

1988, Climatic data for Williams Lake, Hubbard County, Minnesota, 1988: U.S. Geological Survey Open-File Report 88-304, 38 p.

Stark, J.R., and Payne, G.A., 1988, A comparison of hydrologic budgets of two wetlands in Minnesota and Wisconsin [abs.]: Annual Conference—Water for the Years Ahead, Quality and Quantity - 1990 and Beyond, 24th, Milwaukee, Wisconsin, November 6-8, 1988, Proceedings: American Water Resources Association, p. 32.

Trotta, L.C., 1988, Aggregation of Minnesota water-use data and transfer of data to the National water-use data system-Procedures and programs: U.S. Geological Survey Open-File Report 87-40, 71 p.

1988, Inventory of interbasin water transfer in Minnesota, in Symposium on Water Use Data for Water Resources Management, Bethesda, Maryland, August 1988, Proceedings: American Water Resources Association, p. 93-105.

1988, Inventory of interbasin water transfers in Minnesota: U.S. Geological Survey Open-File Report 88-466, $14 \mathrm{p}$.

1988, Sources of water-use data in Minnesota: U.S. Geological Survey Open-File Report 87-544, 2 p.

1988, Water use for aquaculture in Minnesota, 1984: U.S. Geological Survey Water-Resources Investigatic ns Report 88-4159, 6 p.

\section{9}

Anderson, H.W., Jr., 1989, Effects of agriculture on quality of water in surficial sand-plain aquifers in Douglas, Kandiyohi, Pope, and Stearns Counties, Minnesota: U.S. Geological Survey Water-Resources Investigations Report 87-4040, 52 p.

Anderson, H.W., Jr., and Stoner, J.D., 1989, Effects of controlled agricultural practices on water quality in a Minnes nta sand-plain aquifer. U.S. Geological Survey Open-File Report 89-267, 2 p. 
Baehr, A.L., and Hult, M.F., 1989, Determination of the air-phase permeability tensor of an unsaturated zone at the Bemidji, Minnesota research site, in Mallard, G.E., and Ragonc, S.E., eds., U.S. Geological Survey Toxic Substances Hydrology Program-Proceedings of the technical meeting, Phoenix, Arizona, September 26-30. 1988: U.S. Geological Survey Water-Resources Investigations Report 88-4220, p. 55-62.

Brown, R.G., and Stark, J.R., 1989, Hydrologic and water quality characteristics of a wetland receiving wastewater effluent in St. Joseph, Minnesota: Wetlands, v. 9, no. 2, p. 191-206.

Herb, W.J., 1989, Minnesota District Water Resources Division—Information and technical assistance, in Agrichemicals and Ground Water Protection—Resources and Strategies for State and Local Management, St. Paul, Minnesota, October 24-25, 1988 [Proceedings], p. 93-97.

Hult, M.F., 1989, Mobilization, transport, and fate of hydrocarbon vapors in the unsaturated zone [abs.], in Mallard, G.E., and Ragone, S.E., eds., U.S. Geological Survey Toxic Substances Hydrology Program $\longrightarrow$ Proceedings of the technical meeting, Phoenix, Arizona, September 26-30, 1988: U.S. Geological Survey Water-Resources Investigations Report 88-4220, p. 53.

1989. Subsurface contamination at the Bemidji, Minnesota research site [abs.], in Mallard, G.E., and Ragone, S.E., eds., U.S. Geological Survey Toxic Substances Hydrology Program-_Proceedings of the technical meeting, Phoenix, Arizona, September 26-30, 1988: U.S. Geological Survey Water-Resources Investigations Report 88-4220, p. 3.

Lorenz, D.L., and Payne, G.A., 1989, Selected data describing stream subbasins in the Redwood River Basin, southwestern Minnesota: U.S. Geological Survey Open-File Report 89-405, 5 p.

Miller, R.T., 1989, Cyclic injection, storage, and withdrawal of heated water in a sandstone aquifer at St. Paul, Minnesota - Field observations, preliminary model analysis and aquifer thermal energy efficiency: U.S. Geological Survey Open-File Report 89-261, 97 p.

Payne, G.A., 1989, Flow characteristics of the Clearwater River and tributaries from Clearbrook to Plummer, northwestern Minnesota: U.S. Geological Survey Water-Resources Investigations Report 89-4045, 25 p.

Ruhl, J.F., 1989, Flow of ground water through fractured carbonate rocks in the Prairie du Chien-Jordan aquifer, southeastern Minnesota: U.S. Geological Survey Open-File Report 89-253, 2 p.

1989, Water resources of the Fond du Lac Indian Reservation, east-central Minnesota: U.S. Geological Survey Water-Resources Investigations Report 88-4114, 42 p.

1989, Water resources of the White Earth Indian Reservation, northwestern Minnesota: U.S. Geological Survey Water-Resources Investigations Report 89-4074, 73 p.

Schoenberg, M.E., 1989, Factors affecting water-supply potential of the Twin Cities metropolitan area aquifer system: Journal of the Minnesota Academy of Science, v. 55, no. 1, p. 38-47.

1989, Relation of ground-water flow in bedrock aquifers and the Mississippi and Minnesota Rivers, Minneapolis and St. Paul area, Minnesota: U.S. Geological Survey Open-File Report 89-268, 2 p.

Schulze, P.A., and Capel, P.D., 1989, Utility and limitations of immunoassay tests as a field screening method for triazine herbicides [abs.], in Pederson, G.L., and Smith, M.M., compilers, U.S. Geological Survey Second National Symposium on Water Quality-Abstracts of the technical sessions, Orlando, Florida, November, 1217, 1989: U.S. Geological Survey Open-File Report 89-409, p. 86.

Siegel, D.I., 1989, Geochemistry of the Cambrian-Ordovician aquifer system in the northern midwest United States: U.S. Geological Survey Professional Paper 1405-D, 76 p. 
Skinner, J.V., 1989, History of the Federal Inter-Agency Sedimentation Project, in Sediment Transport Modeling International Symposium, New Orleans, Louisiana, August 14-18, 1989, Proceedings: American Society of Civil Engineers, p. 266-271.

1989, Model B sediment concentration gage—Factors influencing its readings and a formula for correcting its errors in measurement and analysis of sediment load in streams: Federal Inter-Agency Sedimentation Projec ${ }^{+}$ Report JJ, 34 p.

Stark, J.R., and Zwilling, D.R., 1989, Effects of ground-water withdrawal for irrigation and quality of Straight River, north-central Minnesota [abs.]: Annual Midwest Ground Water Conference, 34th, Kalamazoo, Michigan, October 18-20, 1987, Proceedings: Western Michigan University, p. 11.

1989. Effects of ground-water withdrawals for irrigation on the quality of the Straight River, north-central Minnesota: U.S. Geological Survey Open-File Report 89-252, 2 p.

Stoner, J.D.. and Schoenberg, M.E., 1989, Preliminary evaluation of effects of ground water withdrawals on Mississippi River flow near the Twin Cities metropolitan area, Minnesota [abs.]: Water supply issues in the Metropolitan Twin Cities area - Planning for the Future Droughts and Population Growth, St. Paul, Minneso+a, October 25, 1988, Proceedings: Minnesota Water Resources Research, p. 5-6.

Tornes. L.H., 1989, Effect of urban runoff on the water quality of lakes in Eagan, Minnesota: U.S. Geological Survey Water-Resources Investigations Report 86-4331, $64 \mathrm{p}$.

Winterstein, T.A., and Arntson, A.D., 1989, Cost-effectiveness of the streamflow gaging program in Minnesota: U.S. Geological Survey Water-Resources Investigations Report 88-4129, 94 p.

\section{0}

Capel, P.D., 1990, Atmospheric deposition of herbicides in Minnesota [abs.]: Minnesota Water 1990-Facing Environmental Challenges of the 1990's, St. Paul, Minnesota, April 1990, Proceedings: Minnesota Water Resources Research, p. 27.

Capel, P.D., 1990, Atmospheric deposition of herbicides in the midcontinental United States [abs.]: EOS, Transactions, American Geophysical Union, v. 71, no. 43, p. 1329.

Capel, P.D., 1990, A bibliography of atrazine and its simple degradation products in the environment: U.S. Geological Survey Open-File Report 89-613, 5 p.

Carlson, G.H., Zandlo, J.A., Nindles, D.B., and Sium, Ogbazghi, 1990, Minnesota floods and drought, in Paulson. R.W., Chase, E.B., Roberts, R.S., and Moody, D.W., compilers, National Water Summary 1988-89: U.S. Geological Survey Water-Supply Paper 2375, p. 345-352.

Delin, G.N., 1990, Effects of differing agricultural practices on concentrations of nitrate and atrazine in a sand-plain aquifer, western Minnesota [abs.]: EOS, Transactions, American Geophysical Union, v. 71, no. 43, p. 1329.

1990. Geohydrology and water quality of confined-drift aquifers in the Brooten-Belgrade area, west-central Minnesota: U.S. Geological Survey Water-Resources Investigations Report 88-4124, 138 p.

1990, Hydrogeology and simulation of ground-water flow in the Rochester area, southeast Minnesota, 197? 88: U.S. Geological Survey Water-Resources Investigations Report 90-4081, 102 p.

1990, Hydrologic considerations for delineating ground water recharge areas for wells, Rochester, Minnesota [abs.]: Minnesota Water 1990 Facing Environmental Challenges of the 1990's, St. Paul, Minnesota, April 1990, Proceedings: Minnesota Water Resources Research, p. 42-43. 
Glysson, G.D., and Skinner, J.V., 1990, Relation between the national handbook of recommended methods for water data acquisition and ASTM standards, in Hall, J.R., and Douglas, G.D., eds., Monitoring Water in the 1990'sMeeting New Challenges: Philadelphia, Pennsylvania, American Society for Testing and Materials, p. 291-300.

Lindgren, R.J., 1990, Simulation of ground-water flow in the Prairie du Chien-Jordan and overlying aquifers near the Mississippi River, Fridley, Minnesota: U.S. Geological Survey Water-Resources Investigations Report 90-4165, $152 \mathrm{p}$.

Lorenz, D.L., 1990, A method for describing stream-drainage system topology in a geographic information system [abs.], in Balthrop, B.H., and Baker, E.G., compilers, U.S. Geological Survey National Computer Technology Meeting-Program and abstracts, San Antonio, Texas, May 7-11, 1990: U.S. Geological Survey Open-File Report 90-161, p. 22.

Lorenz, D.L., and Stark, J.R., 1990, Simulation of ground-water flow in the St. Peter aquifer in an area contaminated by coal-tar derivatives, St. Louis Park, Minnesota: U.S. Geological Survey Water-Resources Investigations Report 90-4150, $37 \mathrm{p}$.

Ruhl, J.F., 1990, Water resources of the Red Lake Indian Reservation, northwestern Minnesota: U.S. Geological Survey Water-Resources Investigations Report 90-4163, 49 p.

Schoenberg, M.E., 1990, Effects of present and projected ground-water withdrawals on the Twin Cities aquifer system, Minnesota: U.S. Geological Survey Water-Resources Investigations Report 90-4001, 165 p.

Schoenberg, M.E., and Mitton, G.B., 1990, Monthly mean discharge at and between selected streamflow-gaging stations along the Mississippi, Minnesota and St. Croix Rivers, 1932-1987: U.S. Geological Survey Open-File Report 90-186, $36 \mathrm{p}$.

Schottler, S.P., Eisenreich, S.J., and Capel, P.D., 1990, Hydrologic and chemical controls on atrazine and alachlor in the Minnesota River [abs.]: EOS, Transactions, American Geophysical Union, v. 71, no. 43, p. 1330.

Smith, C.J., Payne, G.A., and Tornes, L.H., 1990, Effects of impoundments on water quality of streams in the Coteau des Prairie-Upper Minnesota River Basin: U.S. Geological Survey Water-Resources Investigations Report 90$4033,67 \mathrm{p}$.

1990, Hydrologic and water-quality data for streams and impoundments in the Coteau des Prairie-Upper Minnesota River Basin: U.S. Geological Survey Open-File Report 88-84, 43 p.

Stark, J.R., Busch, J.P., and Deters, M.H., 1990, Hydrogeology and water quality of glacial-drift aquifers in the Bemidji-Bagley area, Beltrami, Clearwater, Cass, and Hubbard Counties, Minnesota: U.S. Geological Survey Water-Resources Investigations Report 89-4136, 135 p.

Stark, J.R., and Zwilling, D.R., 1990, Effects of ground-water withdrawal for irrigation and quality of Straight River, north-central Minnesota [abs.]: Transferring Models to Users, Denver, Colorado, November 4-9, 1990, Proceedings: American Water Resources Association, p. 1.

Trotta, L.C., 1990, Automation of data systems $\longrightarrow$ Minnesota's approach for water-use data, in Wiltshire, D.A.,ed., Selected papers in applied computer sciences 1990: U.S. Geological Survey Bulletin 1908, p. F1-F4.

1990, Minnesota water supply and use, in Carr, J.E., Chase, E.B., Paulson, R.W., and Moody, D.W., compilers, National Water Summary 1987: U.S. Geological Survey Water-Supply Paper 2350, p. 313-320.

Trotta, L.C., and Horn, M.A., 1990, Importance of return flow as a component of water use: U.S. Geological Survey Open-File Report 90-179, 2 p. 


\section{1}

Aiken, G.R., Capel, P.D., Furlong, E.T., Hult, M.F., and Thorn, K.A., 1991, Mechanisms controlling the transport of organic chemicals in subsurface environments, in Mallard, G.E., and Aronson, D.A., eds., U.S. Geological Survey Toxic Substances Hydrology Program—Proceedings of the technical meeting, Monterey, California. March 11-15, 1991: U.S. Geological Survey Water-Resources Investigations Report 91-4034, p. 633-637.

Almendinger, J.E., 1991, Relation of nitrate concentrations in ground water to agricultural land use and soil type in Dakota County, Minnesota: U.S. Geological Survey Open-File Report 91-235, 2 p.

Anderson, J.L., Dowdy, R.H., and Delin, G.N., 1991, Ground water impacts from irrigated ridge tillage, in Irrigation and Drainage - 1991 National Conference, Honolulu, Hawaii, July 22-26, 1991, Proceedings: American Sociaty of Civil Engineers, Irrigation and Drainage Division, p. 604-611.

Baehr, A.L., and Hult, M.F., 1991, Evaluation of unsaturated zone air permeability through pneumatic tests: Water Resources Research, v. 27, no. 10, p. 2605-2617.

Capel, P.D., 1991, Wet atmospheric deposition of herbicides in Minnesota, in Mallard, G.E., and Aronson, D.A., eds., U.S. Geological Survey Toxic Substances Hydrology Program-Proceedings of the technical meeting, Monterey, California, March 11-15, 1991: U.S. Geological Survey Water-Resources Investigations Report S14034, p. 334-337.

Capel, P.D., and Barbeau, D.S., 1991, Method for the systematic evaluation of organic chemical retention by solid phase extraction columns, in Mallard, G.E., and Aronson, D.A., eds., U.S. Geological Survey Toxic Substances Hydrology Program—Proceedings of the technical meeting, Monterey, California, March 11-15,1991: U.S. Geological Survey Water-Resources Investigations Report 91-4034, p. 330-333.

Carlson, G.H., 1991, Minnesota floods and drought, in Paulson, R.W., Chase, E.B., Williams, J.S., and Moody, D.w., compilers, National Water Summary 1988-89: U.S. Geological Survey Water-Supply Paper 2375, p. 345-352.

1991, Simulation of effects of ground-water development on water levels in glacial-drift aquifers in the Brooten-Belgrade area, west-central Minnesota: U.S. Geological Survey Water-Resources Investigations Rep rrt 88-4193, 66 p.

Delin, G.N., and Almendinger, J.E., 1991, Delineation of recharge areas for selected wells in the St. Peter-Prairie du Chien-Jordan aquifer, Rochester, Minnesota: U.S. Geological Survey Open-File Report 90-397, 60 p.

Delin, G.N., Anderson. J.L., and Dowdy, R.H., 1991, Integrated hydrologic research at the northern cornbelt sancplain management system evaluation area, Minnesota, in Mallard, G.E., and Aronson, D.A., eds., U.S. Geological Survey Toxic Substances Hydrology Program-Proceedings of the technical meeting, Monterey, California, March 11-15, 1991: U.S. Geological Survey Water-Resources Investigations Report 91-4034, p. 214 218.

Have, M.R., 1991, Selected water-quality characteristics in the Upper Mississippi River Basin, Royalton to Hastings, Minnesota: U.S. Geological Survey Water-Resources Investigations Report 88-4053, 152 p.

1991, Streamflow entering and leaving Lake Bemidji, Beltrami County, Minnesota, July 1989-September 1989: U.S. Geological Survey Open-File Report 91-499, 25 p.

Hotchkiss, R.H., 1991, Particle size distributions by Pipet and sedigraph, in Ian, S.S., and Kuo, Y.H., eds., Federe' Inter-Agency Sedimentation Conference, 5th, Las Vegas, Nevada, March 18-21, 1991, Proceedings: Federal Inter-Agency Sedimentation Project, v. 1, p. 6-47-6-54. 
Hult, M.F., 1991, Overview of research on contamination of the sub surface by crude oil at the Bemidji, Minnesota toxic substances research site, in Mallard, G.E., and Aronson, D.A., eds., U.S. Geological Survey Toxic Substances Hydrology Program-Proceedings of technical meeting, Monterey, California, March 11-15, 1991: U.S. Geological Survey Water-Resources Investigations Report 91-4034, p. 611-613.

Hult, M.F., Landon, M.K., and Pfannkuch, H.O., 1991, Field validation of conceptual models of mobilization and transport of volatile petroleum derivatives in the unsaturated zone near Bemidji, Minnesota, in Mallard, G.E., and Aronson, D.A., eds., U.S. Geological Survey Toxic Substances Hydrology Program-Proceedings of technical meeting, Monterey, California, March 11-15, 1991: U.S. Geological Survey Water-Resources Investigations Report 91-4034, p. 621-626.

Landon, M.K., and Hult, M.F., 1991, Evolution of physical properties and composition of a crude oil spill, in Mallard, G.E., and Aronson, D.A., eds., U.S. Geological Survey Toxic Substances Hydrology Program-Proceedings of the technical meeting, Monterey, California, March 11-15, 1991: U.S. Geological Survey Water-Resources Investigations Report 91-4034, p. 641-645.

Lorenz, D.L., 1991, Describing stream-drainage systems using a geographic information system [abs.]: Water Management of River Systems, New Orleans, Louisiana, September 8-13, 1991, Proceedings: American Water Resources Association, p. 285-286.

Lorenz, D.L., and Payne, G.A., 1991, Selected data for stream subbasins in the Le Sueur River Basin, south-central Minnesota: U.S. Geological Survey Open-File Report 91-62, 8 p.

1991, Selected data for stream subbasins in the Watonwan River Basin, south-central Minnesota: U.S. Geological Survey Open-File Report 91-61, 7 p.

Lorenz, D.L., and Trotta, L.C., 1991, Preparation and comparison of maps showing the depth to water table, Dakota County, Minnesota: U.S. Geological Survey Open-File Report 91-245, 2 p.

Mitton, G.B., 1991, Water quality data for Sauk Lake and tributaries near Sauk Center, Minnesota, 1988-89: U.S. Geological Survey Open-File Report 91-456, 57 p.

Myette, C.F., 1991, Hydrology, water quality, and simulation of ground-water flow at a taconite tailings basin near Keewatin, Minnesota: U.S. Geological Survey Water-Resources Investigations Report 88-4230, 61 p.

Payne, G.A., 1991, Sediment, nutrients, and oxygen demanding substances in the Minnesota River-Selected waterquality data, 1989-90: U.S. Geological Survey Open-File Report 91-498, 37 p.

1991, Water quality of lakes and streams in Voyageurs National Park, Minnesota, 1977-84: U.S. Geological Survey Water-Resources Investigations Report 88-4016, 95 p.

Schottler, S.P., Eisenreich, S.J., and Capel, P.D., 1991, Relations between water discharge and herbicide concentration in the Minnesota River, Minnesota, in Mallard, G.E., and Aronson, D.A., eds., U.S. Geological Survey Toxic Substances Hydrology Program-Proceedings of the technical meeting Monterey, California, March 11-15, 1991: U.S. Geological Survey Water-Resources Investigations Report 91-4034, p. 338-342.

Skinner, J.V., and Szalona, J.J., 1991, Gages for measuring fluvial-sediment concentration, in Ian, S.S., and Kuo, Y.H., eds., Federal Inter-Agency Sedimentation Conference, 5th, Las Vegas, Nevada, March 18-21, 1991: Proceedings: Federal Inter-Agency Sedimentation Project, p. 2.1-2.8.

Smith, S.E., 1991, Water-quality indicators in the Prairie du Chien-Jordan aquifer, southeastern Minnesota: U.S. Geological Survey Open-File Report 91-480, 2 p.

Stoner, J.D., 1991, National Water-Quality Assessment Program—Red River of the North: U.S. Geological Survey Open-File Report 91-151, 2 p. 
Trotta, L.C., 1991, Automation of the water-use data base for Minnesota, in Balthrop, B.H., and Terry, J.E., eds., U.S. Geological Survey National Computer Technology Meeting Proceedings, Phoenix, Arizona, November 14-18, 1988: U.S. Geological Survey Water-Resources Investigations Report 90-4162, p. 131-137.

1991, Water use in Minnesota, 1985: State of Minnesota Department of Natural Resources Water Use Map Series, 1 sheet.

\section{2}

Alexander, E.C., Jr., Guo, Lifeng, Regan, C.P., and Landon, M.K., 1992, Geochemistry of ground water in an outwash aquifer under agricultural fields at the Management Systems Evaluation Area (MSEA) near Princeton, Minnesota [abs.]: EOS, Transactions, American Geophysical Union, v. 73, no. 43, p. 158.

Cowdery. T.K., and Brigham, M.E., 1992, Baseflow dissolved-solids loads to streams of the Red River of the North Basin. South Dakota, North Dakota, and Minnesota [abs.]: Annual Midwest Ground-Water Conference, 37tt Souix Falls, South Dakota, October 14-16, 1992 [Proceedings], p. 38.

Delin, G.N., Anderson, J.L., and Dowdy, R.H., 1992, The Minnesota Management Systems Evaluation Area Projec Assessing the effects of agricultural practices on ground-water quality [abs.]: Minnesota Water Conference, St. Paul, Minnesota, February 13-14, 1992 [Proceedings].

1992. The Minnesota Management Systems Evaluation Area Project-Assessing the effects of agricultural practices on ground-water quality [abs.]: Minnesota Water '92 - Sustaining Water Resources in the '90's and Beyond, Minneapolis, Minnesota, Proceedings: University of Minnesota Water-Resources Research Center.

Delin, G.N., Landon, M.K., Anderson, J.L., and Dowdy, R.H., 1992, Hydrologic research at the Princeton, Minnesota Management Systems Evaluation Area: U.S. Geological Survey Open-File Report 92-107, 2 p.

1992, The Minnesota Management Systems Evaluation Area [abs.]: Agronomy Abstracts of 1992 Annual Meeting, Minneapolis, Minnesota, November 1-6, 1992, Proceedings: American Society of Agronomy, p. 322.

Delin, G.N., Landon, M.K., Healy, R.W., and Olsen, H.W., 1992, Preferential flow through the unsaturated zone beneath a corn field near Princeton, Minnesota [abs.]: Joint Spring Meeting of American Geophysical Unior. Canadian Geophysical Union, and Mineralogical Society of America, Montreal, Canada, May 12-15, 1992, Proceedings: American Geophysical Union, p. 132.

Komor, S.C., 1992, Bidirectional sulfate diffusion in saline-lake sediments - Evidence from Devil's Lake: Geology, v. 20 , no. 4 , p. $319-322$.

1992, Nitrate in Minnesota sand-plain aquifers [abs.]: Joint Spring Meeting of American Geophysical Union, Canadian Geophysical Union, and Mineralogical Society of America, Montreal, Canada, May 12-15, 1992, Proceedings: American Geophysical Union, p. 125.

Komor, S.C.., and Emerson, D.G., 1992, Atrazine and bromide movement through the unsaturated sand plains at sites in Minnesota and North Dakota [abs.]: 1992 North Dakota Water Quality Symposium, Bismarck, North Daknta, March 25-26, 1992, Proceedings: North Dakota State University Extension Service.

Lamb, J.A., Anderson, J.L., Dowdy, R.H., and Delin, G.N., 1992, Northern combelt sandplain MSEA [abs.]: Minnesota Water '92 - Sustaining Water Resources in the '90's and Beyond, Minneapolis, Minnesota, Proceedings: University of Minnesota Water-Resources Research Center.

Landon, M.K., Delin, G.N., Guo, Lifeng, Regan, C.P., Anderson, J.L., and Dowdy, R.H., 1992, Ground-water quality at the Management Systems Evaluation Area near Princeton, Minnesota, 1991 [abs.]: Annual Midwest Ground Water Conference, 37th, Souix Falls, South Dakota, October 14-16, 1992 [Proceedings], p. 30. 
Landon, M.K., and Hult, M.F., 1992, Source mass balance calculated from changes in physical properties and composition of spilled crude oil in the subsurface near Bemidji, Minnesota: EOS, Transactions, American Geophysical Union, v. 73, no. 14, p. 132-133.

Lorenz, D.L., 1992, Integrating and aggregating data from stream-drainage systems using a geographic information system, in Wiltshire, D.A., ed., Selected papers in applied computer sciences 1992: U.S. Geological Survey Bulletin 2016, p. D1-D7.

1992, Using a geographic information system to describe the environmental setting of the Red River of the North Basin [abs.], in Balthrop, B.H., and Baker, E.G., eds., U.S. Geological Survey National Computer Technology Meeting —Program and abstracts, Norfolk, Virginia, May 17-22, 1992: U.S. Geological Survey Open-File Report 92-64, p. 21.

Lorenz, D.L., and Payne, G.A., 1992, Physical characteristics of stream subbasins in the Blue Earth River Basin, south-central Minnesota and north-central Iowa: U.S. Geological Survey Open-File Report 91-512, 10 p.

Smith, S.E., 1992, Water-quality indicators in the Prairie du Chien-Jordan aquifer, southeastern Minnesota [abs.]: Annual Midwest Ground-Water Conference, 37th, Souix Falls, South Dakota, October 14-16, 1992 [Proceedings], p. 41.

Stark, J.R., 1992, Stream-aquifer relations along Straight River, Becker and Hubbard Counties, north-central Minnesota [abs.]: Annual Midwest Ground Water Conference, 37th, Souix Falls, South Dakota, October 14-16, 1992 [Proceedings], p. 36.

Stoner, J.D., and Lorenz, D.L., 1992, Water quality assessment strategy for the Red River of the North Basin, North Dakota, South Dakota, and Minnesota [abs.]: North Dakota Water Quality Symposium, Bismarck, North Dakota, March 25-26, 1992, Proceedings: North Dakota State University Extension Service, p. 291.

Swain, E.B., Engstrom, D.R., Brigham, M.E., Henning, T.A., and Brezonik, P.L., 1992, Increasing rates of atmospheric mercury deposition in midcontinental North America: Science, v. 257, p. 784-787.

Tornes, L.H., Lorenz, D.L., Brigham, M.E., and Stoner, J.D., 1992, Plans for a water-quality assessment of the Red River of the North Basin, Minnesota, North Dakota, and South Dakota [abs.]: Minnesota Water '92 - Sustaining Water Resources in the ' 90 s and Beyond, Minneapolis, Minnesota, Proceedings: University of Minnesota WaterResources Research Center.

Trotta, L.C., Roddy, W.R., Rowan, M.C., and Wilson, E.J., 1992, Source and authority for national water information system II support files [abs.], in Balthrop, B.H., and Baker, E.G., eds., U.S. Geological National Computer Technology Meeting-_Program and abstracts, Norfolk, Virginia, May 17-22, 1992: U.S. Geological Survey Open-File Report 92-64, p. 36.

\section{3}

Amos, G.L., and Winterstein, T.A., 1993, Water-resources activities of the U.S. Geological Survey in Minnesota, 1991: U.S. Geological Survey Open-File Report 93-65, 73 p.

Anderson, H.W., Jr., 1993, Effects of agricultural and residential land use on ground-water quality, Anoka Sand Plain aquifer, east-central Minnesota: U.S. Geological Survey Water-Resources Investigations Report 93-4074, 62 p.

Anderson, J.L., Dowdy, R.H., Lamb, J.A., Delin, G.N., Knighton, Ray, Clay, David, and Lowery, Birl, 1993, Northern cornbelt sand plains Management Systems Evaluation Area, in Agricultural Research to Protect Water Quality, Minneapolis, Minnesota, February 21-24, 1993, Proceedings: Soil and Water Conservation Society, p. 39-47. 
Baedecker, M.J., Cozzarelli, I.M., Bennett, P.C., Eganhouse, R.P., and Hult, M.F., 1993, Evolution of the contaminant plume in an aquifer contamınated with crude oil, Bemidji, Minnesota [abs.], in Morganwalp, D.W., and Aronson, D.A., compilers, U.S. Geological Survey Toxic Substances Hydrology Program-Abstracts of the technical meeting, Colorado Springs, Colorado, September 20-24, 1993: U.S. Geological Survey Open-File Report 93454, p. 103.

Bennett, P.C., Siegel, D.I., Baedecker, M.J., and Hult, M.F., 1993, Crude-oil in a shallow sand and gravel aquifer- - . Hydrology and inorganic chemistry: Applied Chemistry, v. 8, no. 6, p. 529-549.

Delin, G.N., 1993, The Minnesota Management Systems Evaluation Area (MSEA) project—An overview [abs.]: Annual Water Resources Conference, 26th, St. Paul, Minnesota, October 26-27, 1993, Proceedings: American Society of Civil Engineers.

Delin, G.N., and Almendinger, J.E., 1993, Delineation of recharge areas for selected wells in the St. Peter-Prairie du Chien-Jordan aquifer, Rochester, Minnesota: U.S. Geological Survey Water-Supply Paper 2397, 39 p.

Delin, G.N., and Landon, M.K., 1993, Effects of focused recharge on the transport of agricultural chemicals at the Princeton, Minnesota, Management Systems Evaluation Area, 1991-92 [abs.]: Agricultural Research to Protect Water Quality, Minneapolis, Minnesota, February 21-24, 1993, Proceedings: Soil and Water Conservation Society, p. 210-214.

1993, Effects of focused recharge on the transport of agricultural chemicals at the Princeton, Minnesota Management Systems Evaluation Area, 1991-92: U.S. Geological Survey Open-File Report 93-42, 8 p.

1993, Effects of focused recharge on transport of agricultural chemicals at the Princeton, Minnesota Management Systems Evaluation Area, 1991-1992: U.S. Geological Survey Open-File Report 93-79, 2 p.

1993, Effects of topography on the transport of agricultural chemicals near Princeton, Minnesota, 1992 [abs ], in Morganwalp, D.W., and Aronson, D.A., compilers, U.S. Geological Survey Toxic Substances Hydrology Program-Abstracts of the technical meeting, Colorado Springs, Colorado, September 20-24, 1993: U.S. Geological Survey Open-File Report 93-454, p. 91.

Delin, G.N., Landon, M.K., Healy, R.W., and Olsen, H.W., 1993, Spatial variability of unsaturated-zone properties in relation to topography in a sand-plain setting near Princeton, Minnesota [abs.], in Morganwalp, D.W., and Aronson, D.A., compilers, U.S. Geological Survey Toxic Substance Hydrology Program-Abstracts of the technical meeting, Colorado Springs, Colorado, September 20-24, 1993: U.S. Geological Survey Open-File Report 93-454, p. 92.

Hatfield, J.L., Anderson, J.L., Alberts, E.E., Prato, Tony, Watts, D.G., Ward, Andrew, Delin, G.N., and Swank, Robert, 1993, Management Systems Evaluation Areas-An overview: Agricultural Research to Protect Wat :r Quality, Minneapolis, Minnesota, February 21-24, 1993, Proceedings: Soil and Water Conservation Society, p. $1-10$.

Komor, S.C., 1993, Stable isotopes used to evaluate soil-water movements [abs.]: American Geophysical Union Spring Meeting, Baltimore, Maryland, May 24-28, 1993, Proceedings: American Geophysical Union, p. 14C.

Komor, S.C., and Anderson, H.W., Jr., 1993, Nitrogen isotopes as indicators of nitrate sources in Minnesota sand-plain aquifers: Ground Water, v. 31, no. 2, p. 260-270.

Landon, M.K., Delin, G.N., Guo, Lifeng, Regan, C.P., Lamb, J.A., Dowdy, R.H., and Anderson, J.L., 1993, Occurrence of agricultural chemicals in ground water at the Princeton, Minnesota Management Systems Evaluation Area, in Agricultural Research to Protect Water Quality, Minneapolis, Minnesota, February 21-24, 1993, Proceedings: Soil and Water Conservation Society, p. 434-438. 
Landon, M.K., Delin, G.N., Lamb, J.A., Dowdy, R.H., and Anderson, J.L., 1993, Effects of farming systems on ground water quality at the Princeton, Minnesota Management Systems Evaluation Area, 1991 [abs.], in Morganwalp, D.W., and Aronson. D.A., compilers, U.S. Geological Toxic Substances Hydrology Program-Abstracts of the technical meeting, Colorado Springs, Colorado: U.S. Geological Survey Open-File Report 93-454, p. 63.

Landon, M.K., Delin, G.N., Lamb, J.A., and Guo, Lifeng, 1993, Ground-water quality at the Management Systems Evaluation Area (MSEA) near Princeton, Minnesota, 1991: U.S. Geological Survey Open-File Report 93-43, 8 p.

-1993, Ground-water quality at the Management Systems Evaluation Area near Princeton, Minnesota, 1991: U.S. Geological Survey Open-File Report 93-80, 2 p.

Landon, M.K., and Hult, M.F., 1993, Source mass balance calculated from changes on composition of spilled crude oil in the subsurface near Bemidji, Minnesota [abs.], in Morganwalp, D.W., and Aronson, D.A., compilers, U.S. Geological Survey Toxic Substances Hydrology Program-Abstracts of the technical meeting. Colorado Springs, Colorado, September 20-24, 1993: U.S. Geological Survey Open-File Report 93-454, p. 105.

Miller, R.T., and Delin, G.N., 1993, Field observations, preliminary model analysis, and aquifer thermal efficiencyCyclic injection, storage and withdrawal of heated water in a sandstone aquifer at St. Paul, Minnesota: U.S. Geological Survey Professional Paper 1530-A, 55 p.

Piatt, J.J., Eisenreich, S.J., Barkhus, D.A., and Capel, P.D., 1993, Sorption of polycyclic aromatic hydrocarbons to aquifer materials containing low-organic carbon content from Bemidji, Minnesota [abs.], in Morganwalp, D.W., and Aronson, D.A., compilers, U.S. Geological Survey Toxic Substances Hydrology Program - Abstracts of the technical meeting, Colorado Springs, Colorado, September 20-24, 1993: U.S. Geological Survey Open-File Report 93-454, p. 129.

Revesz, Kinga, Copen, Tyler, Baedecker, M.J., and Hult, M.F., 1993, Use of carbon and hydrogen stable isotopes to investigate the production and fate of methane at a toxic waste site, Bemidji, Minnesota [abs.], in Morganwalp. D.W., and Aronson, D.A., compilers, U.S. Geological Survey Toxic Substances Hydrology Program-Abstracts of the technical meeting, Colorado Springs, Colorado, September 20-24, 1993: U.S. Geological Survey OpenFile Report 93-454, p. 128.

Schulze, P.A., Capel, P.D., Squillace, P.J., and Helsel, D.R., 1993, A laboratory and field evaluation of a portable immunoassay test for triazine herbicides in environmental water samples: International Journal of Environmental Analytical Chemistry, v. 53, p. 307-319.

Smith, S.E., and Hult, M.F., 1993, Crude-oil spill research project near Bemidji, Minnesota-A bibliography, 1984 1994: U.S. Geological Survey Open-File Report 93-373, 15 p.

1993, Hydrogeologic data collected from a crude oil spill site near Bemidji, Minnesota, 1983-91: U.S. Geological Survey Open-File Report 93-496, 158 p.

Stoner, J.D., Lorenz, D.L., Wiche, G.J., and Goldstein, R.M., 1993, Red River of the North Basin, Minnesota, North Dakota, and South Dakota: Water Resources Research Bulletin, v. 29, no. 4, p. 575-615.

Trotta, L.C., and Lorenz, D.L., 1993, Comparison of maps showing the depth to water table (Dakota County, Minnesota) prepared by traditional GIS methods [abs.]: Geographic Information Systems and Water Resources, Mobile, Alabama, March 14-17, 1993, Proceedings: American Water Resources Association, p. 52.

Wanty, R.B., Tuttle, M.L., Landon, M.K., Delin, G.N., and Bohlke, J.K., 1993, Geochemistry of nitrogen in a farmed watershed near Princeton, Minnesota [abs.], in Morganwalp, D.W., and Aronson, D.A., compilers, U.S. Geological Survey Toxic Substances Hydrology Program - Abstracts of the technical meeting, Colorado Springs, Colorado, September 20-24, 1993: U.S. Geological Survey Open-File Report 93-454, p. 93.

Winterstein, T.A., Payne, G.A., Miller, R.A., and Stark, J.R., 1993, Selected basin characteristics and water-quality data for the Minnesota River Basin: U.S. Geological Survey Open-File Report 93-164, 100 p. 
Almendinger, J.E., 1994, The travel-time ellipse—An approximate zone of transport: Journal of Hydrology (161), p. 365-373.

Almendinger, J.E., and Leete, Jeanette, 1994, Hydrology, geochemistry, and substrate of calcareous fens in the Minnesota River Basin [abs.]: Minnesota Water '94 Managing Minnesota's Rivers and Watersheds, Minneapolis, Minnesota, April 21-22, 1994 [Proceedings], p. 7.

Amos, G.L., 1994, Water-resources activities of the U.S. Geological Survey Minnesota District, 1993 water year: U.S. Geological Survey Open-File Report 94-338, 72 p.

Bohlke, J.K., Wanty, R.B., Tuttle, M.L., Delin, G.N., and Landon, M.K., 1994, Resolving the effects of varying lard use and aquifer reactions on nitrate contamination of ground water in central Minnesota [abs.]: EOS, Transactions, American Geophysical Union, v. 75, no. 19, p. 154.

Brigham, M.E., 1994, Pesticides detected in surface waters and fish of the Red River of the North drainage basin [abs ]: North Dakota Water-Quality Symposium, 4th biennial, Fargo, North Dakota, March 30-31, 1994, Proceedings: North Dakota State University Extension Service, p. 26.

Brigham, M.E., Tornes, L.H., and Lorenz, D.L., 1994, Load estimates for pesticides in the Red River of the North drainage basin [abs.]: American Geophysical Union 1994 Fall Meeting, San Francisco, California, December 59, 1994, Proceedings: American Geophysical Union, p. 230.

1994, Pesticides detected in surface waters and fish of the Red River of the North drainage basin: in North Dakota Water-Quality Symposium, 4th biennial, Fargo, North Dakota, March 30-31, 1994, Proceedings: North Dakota State University Extension Service, p. 256-269.

Carlson, G.H., 1994, Changes in 100-year flood discharge estimates with varying period of record on Minnesota streams [abs.]: Minnesota Water '94 Managing Minnesota's Rivers and Watersheds, Minneapolis, Minnesota, April 21-22, 1994 [Proceedings], p. 11.

Cowdery, T.K., 1994, Nutrient concentrations near the water table of the Sheyenne Delta aquifer beneath cropland areas-Preliminary results from a Red River of the North Basin land-use study [abs.], in Sorenson, S.K., ed, Proceedings Abstracts-American Water Resources Association's Symposium on the National Water-Quality Assessment (NAWQA) Program, Chicago, Illinois, November 7-9, 1994: U.S. Geological Survey Open-File Report 94-397, p. 7.

Cowdery, T.K., and Goff, Karin, 1994, Nitrogen concentrations near the water table of the Sheyenne Delta aquifer beneath cropland areas, near Ransom and Richland Counties, North Dakota [abs.]: North Dakota Water-Quality Symposium, 4th biennial, Fargo, North Dakota, March 30-31, 1994, Proceedings: North Dakota State University Extension Service, p. 14.

1994, Nitrogen concentrations near the water table of the Sheyenne Delta aquifer beneath cropland areas, Ransom and Richland Counties, North Dakota, in North Dakota Water-Quality Symposium, 4th biennial, Farg?, North Dakota, March 30-31, 1994, Proceedings: North Dakota State University Extension Service, p. 89-102..

1994, Nutrient concentrations near the water table of the Sheyenne Delta aquifer beneath cropland areas, Ransom and Richland Counties, North Dakota [abs.]: Minnesota Water '94_Managing Minnesota's Rivers and Watersheds, Minneapolis, Minnesota, April 21-22, 1994 [Proceedings], p. 8-9.

Delin, G.N., and Landon, M.K., 1994, Effects of focused recharge on the transport of agricultural chemicals near Princeton, Minnesota, 1992 [abs.]: Minnesota Water '94 -Managing Minnesota's Rivers and Watersheds, Minneapolis, Minnesota, April 21-22, 1994 [Proceedings], p. 9. 
Delin, G.N., Landon, M.K., Healy, R.W., and Olsen, H.W., 1994, Spatial distribution of unsaturated-zone properties in relation to topography near Princeton, Minnesota [abs.]: Mirnesota Water '94-Managing Minnesota's Rivers and Watersheds, Minneapolis, Minnesota, April 21-22, 1994 [Proceedings], p. 9.

Delin, G.N., Landon, M.K., Lamb, J.A., and Anderson, J.L., 1994, Characterization of the hydrogeology and water quality at the Management Systems Evaluation Area near Princeton, Minnesota, 1991-92: U.S. Geological Survey Water-Resources Investigations Report 94-4149, 54 p.

1994, Hydrogeologic and water-quality data used to characterize the Management Systems Evaluation Area near Princeton, Minnesota, 1991: U.S. Geological Survey Open-File Report 94-337, 42 p.

Goldstein, R.M., Simon, T.P., Bailey, P.A., Ell, Michael, Pearson, Eric, Schmidt, Konrad, and Enblom, J.W., 1994, Concepts for an index of biotic integrity for stream of the Red River of the North Basin [abs.]: North Dakota Water-Quality Symposium, 4th biennial, Fargo, North Dakota, March 30-31, 1994, Proceedings: North Dakota State University Extension Service, p. 19.

1994, Concepts for an index of biotic integrity for streams of the Red River of the North Basin, in North Dakota Water-Quality Symposium, 4th biennial, Fargo, North Dakota, March 30-31, 1994, Proceedings: North Dakota State University Extension Service, p. 169-180.

Guo, Lifeng, Alexander, E.C.,Jr., Landon, M.K., Delin, G.N., and Regan, C.P., 1994, Geochemical characteristics and transport of agricultural leachates in a surficial sand and gravel aquifer near Princeton, Minnesota, 1991-92

[abs.]: 1993 Fall Meeting, San Francisco, California, December 6-10, 1993, Proceedings: American Geophysical Union, p. 269.

Hoyer, M.C., Hallgren, J.P., Uebel., M.H., Delin, G.N., Eisenreich, S.J., and Sterling, R.L., 1994, University of Minnesota Aquifer Thermal-Energy Storage (ATES) project report on the third long-term cycle: University of Minnesota, $125 \mathrm{p}$.

Komor, S.C., 1994, Bottom-sediment chemistry in Devil's Lake, northeast North Dakota: Sedimentology and Geochemistry of Modern and Ancient Saline Lakes, no. 50, p. 21-32.

1994, Geochemistry and hydrology of a calcareous fen within the Savage Fen wetlands complex, Minnesota, USA: Geochimica et Cosmochimica Acta, v. 58, no. 16, p. 3353-3367.

1994, Geochemistry and hydrology of Savage Fen, a calcareous fen in the Minnesota River Valley [abs]: Minnesota Water '94-Managing Minnesota's Rivers and Watersheds, Minneapolis, Minnesota, April 21-22, 1994 [Proceedings], p. 9.

1994, Petrography and chemistry of calcite in the KTB borehole, Germany [abs.]: International Symposium on the Observation of the Continental Crust Through Drilling, 7th, Sante Fe, New Mexico, April 25-30, 1994 [Proceedings].

Komor. S.C., and Emerson, D.G., 1994, Movements of water, solutes, and stable isotopes in the unsaturated zones of two sandplains in the Upper Midwest: Water Resources Research, v. 30, no. 2, p. 253-267.

Landon, M.K., Delin, G.N., Komor, S.C., and Regan, C.P., 1994, Stable isotopes and major anions as tracers of recharge water to a sand and gravel aquifer, central Minnesota [abs.]: EOS, Transactions, American Geophysical Union, v. 73, no. 44 , p. 277.

Landon, M.K., Delin, G.N., Lamb, J.A., Anderson, J.L., and Dowdy, R.H., 1994, Impacts of farming systems on ground-water quality at the Princeton, Minnesota, Management Systems Evaluation Area (MSEA) 1991-1992 [abs.]: Minnesota Water '94 Managing Minnesota's Rivers and Watersheds, Minneapolis, Minnesota April 2122, 1994 [Proceedings], p. 6. 
Landon, M.K., Delin, G.N., Lamb, J.A., Dowdy, R.H., and Anderson, J.L., 1994, Effects of farming systems on concentrations of nitrate in ground water at the Princeton, Minnesota Management Systems Evaluation Are? (MSEA), 1991-1992 [abs.]: EOS, Transactions, American Geophysical Union, v. 75, no. 19, p. 157.

Lorenz, D.L., 1994, Use of remotely sensed data to characterize vegetation in the Red River of the North Basin, Minnesota, North Dakota, and South Dakota [abs.], in Balthrop, B.H., and Baker, E.G., compilers, U.S. Geological Survey National Computer Technology Meeting - Program and abstracts. New Orleans, Louisic na April 10-15, 1994: U.S. Geological Survey Open-File Report 94-52, p. 27.

Lorenz, D.L., and Payne, G.A., 1994, Physical characteristics of stream subbasins in the Pomme de Terre River Barin, west-central Minnesota: U.S. Geological Survey Open-File Report 93-47, 8 p.

Lorenz, D.L., Sanocki, C.A., and Winterstein, T.A., 1994, Physical characteristics of stream subbasins in the Lac qui Parle River Basin, southwestern Minnesota and eastern South Dakota: U.S. Geological Survey Open-File Report 93-46, $12 \mathrm{p}$.

Payne, G.A., 1994, Ground-water base flow to the Upper Mississippi River upstream of the Minneapolis-St. Paul a*ea, Minnesota during July 1988, in Water Available from the Mississippi River at Minneapolis and Other Upstream Minnesota Locations During Low-Flow Conditions: U.S. Army Corps of Engineers, p. C1-C36.

1994, Sources and transport of sediment, nutrients, and oxygen-demanding substances in the Minnesota River Basin, 1989-92: U.S. Geological Survey Water-Resources Investigations Report 93-4232, 71 p.

Ruhl, J.F., 1994, Nitrate-N concentration distribution and the presence of selected pesticides in the surficial sand aquifer of the Straight River Basin, north-central Minnesota, 1991-93 [abs.]: Midwest Ground-Water Conference, 39th, Bismarck, North Dakota, October 16-18, 1994 [Proceedings], p. 28.

Ruhl, J.F., 1994, Quality of ground water around Vadnais Lake and in Lambert Creek watershed, and interaction of ground water with Vadnais Lake, Ramsey County, Minnesota: U.S. Geological Survey Water-Resources Investigations Report 94-4062, $59 \mathrm{p}$.

Sanocki, C.A., and Krumrie, J.R., 1994, Physical characteristics of stream subbasins in the Chippewa River Basin, west-central Minnesota: U.S. Geological Survey Open-File Report 94-488, 16 p., 1 sheet, scale 1:100,000.

Schoenberg, M.E., 1994, Characterization of ground-water discharge from bedrock aquifers to the Mississippi and Minnesota Rivers at three areas, Minneapolis-St. Paul area, Minnesota: U.S. Geological Survey WaterResources Investigations Report 94-4163, 45 p.

Smith, S.E., 1994, Water-quality along selected flow paths in the Prairie du Chien-Jordan aquifer, southeastern Minnesota [abs.]: Geological Society of America Abstracts with Programs, v. 26, no. 5, p. 61-62.

Stark, J.R., 1994, National Water-Quality Assessment Program for the Upper Mississippi River Basin: U.S. Geological Survey Open-File Report 94-101, 2 p.

1994, Plans for a water quality assessment of the Upper Mississippi River Basin [abs.]: Annual Meeting of the Mississippi River Research Consortium, 26th, LaCrosse, Wisconsin, April 28-29, 1994 [Proceedings], p. $1 \varepsilon$.

1994, Plans for water-quality assessment of the Upper Mississippi River Basin [abs.]: Sustaining the Ecological Integrity of Large Floodplain Rivers-Application of Ecological Knowledge to River Management, LaCrosse, Wisconsin, July 12-15, 1994 [Proceedings], p. 157.

1994, Upper Mississippi River Basin water quality assessment [abs.]: Minnesota Water ' 94 Managing Minnesota's Rivers and Watersheds, Minneapolis, Minnesota, April 21-22, 1994 [Proceedings], p. 16. 
Stark, J.R., Armstrong, D.S., and Zwilling, D.R., 1994, Stream-aquifer interactions in the Straight River area, Becker and Hubbard Counties, Minnesota: U.S. Geological Survey Water-Resources Investigations Report 94-4009, 83 p.

Stoner, J.D., Brigham, M.E., and Cowdery, T.K., 1994, Water quality in surficial glacial-deposit aquifers in the Red River of the North drainage basin, Minnesota, North Dakota, and South Dakota [abs.]: Midwest Ground Water Conference, 39th, Bismarck, North Dakota, October 16-18, 1994 [Proceedings], p. 15.

Stoner, J.D., and Lorenz, D.L., 1994, Environmental setting of the Red River of the North Basin, Minnesota, North Dakota, and South Dakota—Framework for a regional water quality assessment [abs.]: Minnesota Water ' 94 Managing Minnesota's Rivers and Watersheds, Minneapolis, Minnesota, April 21-22, 1994 [Proceedings], p. 23.

Tornes, L.H., and Brigham, M.E., 1994, Agricultural chemicals in streams of the Red River of the North drainage basin [abs.]: Minnesota Water '94-Managing Minnesota's Rivers and Watersheds, Minneapolis, Minnesota, April 21-22, 1994 [Proceedings], p. 3.

1994, Nutrients, suspended sediment, and pesticides in waters of the Red River of the North Basin, Minnesota, North Dakota, and South Dakota, 1970-90: U.S. Geological Survey Water-Resources Investigations Report 93$4231,62 \mathrm{p}$.

Tornes, L.H., Puckett, L.J., Stoner, J.D., and Brigham, M.E., 1994 The effect of riparian wetlands in reducing nitrate nitrogen from a sand and gravel aquifer to a stream [abs.]: American Geophysical Union 1994 Fall Meeting, San Francisco, California, December 5-9, 1994, Proceedings: American Geophysical Union, p. 261.

Winterstein, T.A., and Miller, R.A., 1994, A collaborative approach to electronic report production [abs.], in Balthrop, B.H., and Baker, E.G., compilers, U.S. Geological Survey National Computer Technology Meeting-Program and abstracts, New Orleans, Louisiana, April 10-15, 1994: U.S. Geological Survey Open-File Report 94-52, p. 59. 


\section{Alphabetical Listing by Author}

Adolphson, D.G., 1983, Availability and chemical quality of water from surficial aquifers in southwest Minnesot»: U.S. Geological Survey Water-Resources Investigations Report 83-4030, 37 p.

Adolphson, D.G., and Jannis, J.A., 1978, Status of projects in Minnesota fiscal year 1978: U.S. Geological Survey, $101 \mathrm{p}$.

Adolphson, D.G., Ruhl, J.R., and Wolf, R.J., 1981, Designation of principal water-supply aquifers in Minnesota: U.S. Geological Survey Water-Resources Investigations Report 81-51, 19 p.

Aiken, G.R., Capel, P.D., Furlong, E.T., Hult, M.F., and Thorn, K.A., 1991, Mechanisms controlling the transp rrt of organic chemicals in subsurface environments, in Mallard, G.E., and Aronson, D.A., eds., U.S. Geological Survey Toxic Substances Hydrology Program-Proceedings of the technical meeting, Monterey, California, March 11-15, 1991: U.S. Geological Survey Water-Resources Investigations Report 91-4034, p. 633-637.

Akin, P.D., 1951, Preliminary report on ground-water conditions in the Cloquet area, Carlton County, Minnesota: U.S. Geological Survey, 11 p.

Akin, P.D., and Jones, J.R., 1952, Geology and ground-water resources of the Cloquet area, Carlton County, Minnesota: Minnesota Department of Conservation, Division of Waters Bulletin 6, 63 p.

Albin, D.R., 1987, Minnesota ground-water quality: U.S. Geological Survey Open-File Report 87-733, 10 p. 1988, U.S. Geological Survey ground-water studies in Minnesota: U.S. Geological Survey Open-File Repcrt $88-127,2 \mathrm{p}$.

Albin, D.R., and Breummen, L.B., 1987, Minnesota ground-water quality, in Moody, D.W., Carr, Jerry, Chase, E.B., and Paulson, R.W., compilers, National Water Summary 1986: U.S. Geological Survey Water-Supply Paper 2325, p. 313-320.

Alexander, E.C., Jr., Guo, Lifeng, Regan, C.P., and Landon, M.K., 1992, Geochemistry of ground water in an outwash aquifer under agricultural fields at the Management Systems Evaluation Area (MSEA) near Princeton, Minnesota [abs.]: EOS, Transactions, American Geophysical Union, v. 73, no. 43, p. 158.

Almendinger, J.E., 1991, Relation of nitrate concentrations in ground water to agricultural land use and soil type in Dakota County, Minnesota: U.S. Geological Survey Open-File Report 91-235, 2 p.

1994, The travel-time ellipse—An approximate zone of transport: Journal of Hydrology (161), p. 365-373.

Almendinger, J.E., and Leete, Jeanette, 1994, Hydrology, geochemistry, and substrate of calcareous fens in the Minnesota River Basin [abs.]: Minnesota Water '94 Managing Minnesota's Rivers and Watersheds, Minneapolis, Minnesota, April 21-22, 1994 [Proceedings], p. 7.

Amos, G.L., 1994, Water-resources activities of the U.S. Geological Survey Minnesota District, 1993 water year: U.S. Geological Survey Open-File Report 94-338, 72 p.

Amos, G.L., and Winterstein, T.A., 1993, Water-resources activities of the U.S. Geological Survey in Minnesot . 1991: U.S. Geological Survey Open-File Report 93-65, 73 p.

Anderson, D.B., 1973, Drainage ditch inventory, State of Minnesota: Unpublished report on file with U.S. Geologisal Survey in Mounds View, Minnesota. $230 \mathrm{p}$.

Anderson, D.B., and Schwob, H.H., 1970, Floods of April-May 1969 in upper midwestern United States: U.S. Geological Survey Open-File Report, 555 p.

Anderson, H.W., Jr., 1980, Minnesota standards for coding ground-water site inventory data: Unpublished report on file with U.S. Geological Survey in Mounds View, Minnesota, $57 \mathrm{p}$. 
1985, Impact of agriculture on quality of water in surficial sand-plain aquifers in central Minnesota [abs.]: Annual Midwest Ground Water Conference, 30th, St. Paul, Minnesota, October 23-25, 1985 [Proceedings], p. 9.

1986, Hydrogeologic and water-quality characteristics of crystalline-rock aquifers of Archean and Proterozoic age, Minnesota: U.S. Geological Survey Water-Resources Investigations Report 86-4033, 3 sheets.

- 1989, Effects of agriculture on quality of water in surficial sand-plain aquifers in Douglas, Kandiyohi, Pope, and Stearns Counties, Minnesota: U.S. Geological Survey Water-Resources Investigations Report 87-4040, 52 p.

1993, Effects of agricultural and residential land use on ground-water quality, Anoka Sand Plain aquifer, eastcentral Minnesota: U.S. Geological Survey Water-Resources Investigations Report 93-4074, 62 p.

Anderson, H.W., Jr., Broussard, W.L., Farrell, D.F., and Felsheim, P.E., 1976, Water resources of the Rock River watershed, southwestern Minnesota: U.S. Geological Survey Hydrologic lnvestigations Atlas HA-555, 3 sheets, scale $1: 250,000$.

Anderson, H.W., Jr., Broussard, W.L., Farrell, D.F., and Hult, M.F., 1976, Water resources of the Des Moines River watershed, southwestern Minnesota: U.S. Geological Survey Hydrologic Investigations Atlas HA-553, 3 sheets, scales $1: 250,000$ and $1: 500,000$.

Anderson, H.W., Jr., Farrell, D.F., and Broussard, W.L., 1974, Water resources of the Blue Earth River watershed, south-central Minnesota: U.S. Geological Survey Hydrologic Investigations Atlas HA-525, 3 sheets, scale $1: 500,000$.

1974, Water resources of the lower Minnesota River watershed, south-central Minnesota: U.S. Geological Survey Hydrologic Investigations Atlas HA-526, 3 sheets, scale 1:500,000.

Anderson, H.W., Jr., Farrell, D.F., Broussard, W.L., and Felsheim, P.E., 1974, Water resources of the Cannon River watershed, southeastern Minnesota: U.S. Geological Survey Hydrologic Investigations Atlas HA-522, 3 sheets, scales 1:250,000 and 1:500,000.

Anderson, H.W., Jr., Farrell, D.F., Broussard, W.L., and Hult, M.F., 1975, Water resources of the Zumbro River watershed, southeastern Minnesota: U.S. Geological Survey Hydrologic Investigations Atlas HA-543, 3 sheets, scale 1:250,000.

Anderson, H.W., Jr., and Ruhl, J.F., 1984, Geohydrology and hydrochemistry of aquifers in Cretaceous rocks, Minnesota, in Geohydrology of the Dakota aquifer, C.V. Theis Conferences on Geohydrology, 1st, Lincoln, Nebraska, October 5-6, 1982, Proceedings: National Water Well Association, p. 27-37.

Anderson, H.W., Jr., and Stoner, J.D., 1989, Effects of controlled agricultural practices on water quality in a Minnesota sand-plain aquifer: U.S. Geological Survey Open-File Report 89-267, 2 p.

Anderson, J.L., Dowdy, R.H., and Delin, G.N., 1991, Ground water impacts from irrigated ridge tillage, in Irrigation and Drainage - 1991 National Conference, Honolulu, Hawaii, July 22-26, 1991, Proceedings: American Society of Civil Engineers, Irrigation \& Drainage Division p. 604-611.

Anderson, J.L., Dowdy, R.H., Lamb, J.A., Delin, G.N., Knighton, Ray, Clay, David, and Lowery, Birl, 1993, Northern cornbelt sand plains Management Systems Evaluation Area, in Agricultural Research to Protect Water Quality, Minneapolis, Minnesota, February 21-24, 1993, Proceedings: Soil and Water Conservation Society, p. 39-47.

Arntson, A.D., and Lorenz, D.L., 1987, Low-flow frequency characteristics for continuous-record streamflow stations in Minnesota: U.S. Geological Survey Water-Resources Investigations Report 86-4353, 15 p. 
Arntson, A.D., and Tornes, L.H., 1985, Rainfall-runoff relationship and water-quality assessment of Coon Creek watershed, Anoka County, Minnesota: U.S. Geological Survey Water-Resources Investigations Report 84-4013, 97 p.

Ayers, M.A., Brown, R.G., and Oberts, G.L., 1985, Runoff and chemical loading in small watersheds in the Twin Cities metropolitan area, Minnesota: U.S. Geological Survey Water-Resources Investigations Report 85-4122, 35 p.

Ayers, M.A., Payne, G.A., and Have, M.R., 1980, Effects of urbanization on the water quality of lakes in Eagan, Minnesota: U.S. Geological Survey Water-Resources Investigations Report 80-71, 42 p.

Ayers, M.A, Payne, G.A., and Oberts, G.L., 1980, Quality of runoff from small watersheds in the Twin Cities metropolitan area, Minnesota - A project plan: U.S. Geological Survey Open-File Report 80-592, 31 p.

Baedecker, M.J, Cozzarelli, I.M. Bennett, P.C., Eganhouse, R.P., and HuIt, M.F., 1993, Evolution of the contaminant plume in an aquifer contaminated with crude oil, Bemidji, Minnesota [abs.], in Morganwalp, D.W'., and Aronson, D.A., compilers, U.S. Geological Survey Toxic Substances Hydrology Program-Abstracts of the technical meeting, Colorado Springs, Colorado, September 20-24, 1993: U.S. Geological Survey Open-File Report 93-454, p. 103.

Baedecker, M.J, Eganhouse, R.P., Miller, R.T., and Hult, M.F., 1986, The composition and fate of hydrocarbons in a glacial aquifer [abs:]: Symposium on Scientific Advances in Geology and Hydrology from Studies of Contaminant Plumes, San Antonio, Texas, November 1986, Proceedings: Geological Society of America, v.18, no. 6, p. 531 .

Baehr, A.L., and Hult, M.F., 1987, Mathematical modeling of hydrocarbon and oxygen transport coupled with microbial degradation in the unsaturated zone [abs.], in Franks, B.J., ed., U.S. Geological Survey program on toxic waste-ground-water contamination-Proceedings of the third technical meeting, Pensacola, Florida, March 23-27, 1987: U.S. Geological Survey Open-File Report 87-109, p. C-27-28.

1989, Determination of the air-phase permeability tensor of an unsaturated zone at the Bemidji, Minnesota research site, in Mallard, G.E., and Ragone, S.E., eds., U.S. Geological Survey Toxic Substances Hydrology Program-Proceedings of the technical meeting, Phoenix, Arizona, September 26-30, 1988: U.S. Geological Survey Water-Resources Investigations Report 88-4220, p. 55-62.

1991, Evaluation of unsaturated zone air permeability through pneumatic tests: Water Resources Research, v. 27, no. 10, p. 2605-2617.

Bath, G.D., Schwartz, G.M., and Gilbert, F.P., 1964, Aeromagnetic and geologic map of northwestern Minnesota: U.S. Geological Survey Geophysical Investigations Map GP-471, 1 sheet, scale 1:250,000.

Bennett, P.C. Siegel, D.I., Baedecker, M.J., and Hult, M.F., 1993, Crude-oil in a shallow sand and gravel aquifer-1. Hydrology and inorganic chemistry: Applied Chemistry, v. 8, no. 6, p. 529-549.

Beverage, J.P., and Futrell, J.C., 1986, Comparison of flume and towing methods for verifying the calibration of a suspended-sediment sampler. U.S. Geological Survey Water-Resources Investigations Report 86-4193, 11 p.

Beverage, J.P, and Skinner, J.V., 1973, Automatic tracking attachment for the visual-accumulation-tube size analyzer. Federal Inter-Agency Sedimentation Project, 15 p.

Bidwell, L.E. Winter, T.C., and Maclay, R.W., 1970, Water resources of the Red Lake River watershed, northwestern Minnesota: U.S. Geological Survey Hydrologic Investigations Atlas HA-346, 4 sheets, scales $1: 500,000$ and $1: 250,000$.

Bingham, J.W., 1960, Basic geology and ground-water data for Clay County, Minnesota: Minnesota Department of Conservation, Division of Waters Bulletin 8, $138 \mathrm{p}$. 
Bohlke, J.K., Wanty, R.B., Tuttle, M.L, Delin, G.N., and Landon, M.K., 1994, Resolving the effects of varying land use and aquifer reactions on nitrate contamination of ground water in central Minnesota [abs.]: EOS, Transactions, American Geophysical Union, v. 75, no. 19, p. 154.

Books, K.G., Schwartz, G.M., Meuschke, J.L., and Dempsey, W.J., 1958, Aeromagnetic maps of eastern Roseau County, Minnesota: U.S. Geological Survey Geophysical Investigations Map GP-140, 2 sheets, scale 1:63,360.

- 1958, Aeromagnetic map of Kittson County, Minnesota: U.S. Geological Survey Geophysical Investigations Map GP-142, 2 sheets, scale 1:63,630.

1958, Aeromagnetic maps of western Roseau County, Minnesota: U.S. Geological Survey Geophysical Investigations Map GP-141, 2 sheets, scale 1:63,360.

Brigham, M.E., 1994, Pesticides detected in surface waters and fish of the Red River of the North drainage basin [abs.]: North Dakota Water-Quality Symposium, 4th biennial, Fargo, North Dakota, March 30-31, 1994, Proceedings: North Dakota State University Extension Service, p. 26.

1994, Pesticides detected in surface waters and fish of the Red River of the North drainage basin, in North Dakota Water-Quality Symposium, 4th biennial, Fargo, North Dakota, March 30-31, 1994, Proceedings: North Dakota State University Extension Service, p. 256-269.

Brigham, M.E., Tornes, L.H., and Lorenz, D.L., 1994, Load estimates for pesticides in the Red River of the North drainage basin [abs.]: American Geophysical Union 1994 Fall Meeting, San Francisco, California, December 59, 1994, Proceedings: American Geophysical Union, p. 230.

Broussard, W.L., Anderson, H.W., Jr., and Farrell, D.F., 1973, Water resources of the Cottonwood River watershed, southeastern Minnesota: U.S. Geological Survey Hydrologic Investigations Atlas HA-466, 3 sheets, scales $1: 253,440$ and $1: 250,000$.

Broussard, W.L., Farrell, D.F., Anderson, H.W., Jr., and Felsheim, P.E., 1975, Water resources of the Root River watershed, southeastern Minnesota: U.S. Geological Survey Hydrologic Investigations Atlas HA-548, 3 sheets, scale 1:250,000.

Brown, R.G., 1983, Atmospheric deposition of selected chemicals and their effect on nonpoint-source pollution in the Twin Cities metropolitan area, Minnesota: U.S. Geological Survey Water-Resources Investigations Report 83$4195,24 \mathrm{p}$.

1984, Effects of an urban wetland on sediment and nutrient loads in runoff: Wetlands, v. 4, p. 147-158.

1984, Hydrologic effects of impoundments in Sherburne National Wildlife Refuge, Minnesota: U.S. Geological Survey Water-Resources Investigations Report 84-4175, 20 p.

1984, Precipitation and streamflow data - Collections techniques, in Understanding Watershed and Lake Management Conference, Bloomington, Minnesota, March 23, 1984 [Proceedings], p. 18-29.

-1984, Relationship between quantity and quality of storm runoff and various watershed, characteristics in Minnesota, USA, in International Conference on Urban Storm Drainage, 3rd, Goteborg, Sweden, June 4-8, 1984 [Proceedings], p. 791-799.

-1985, Effects of wetlands on quality of runoff entering lakes in the Twin Cities metropolitan area, Minnesota: U.S. Geological Survey Water-Resources Investigations Report 85-4170, 32 p.

1985, Errors associated with estimating ground-water flow and phosphorus flux components in hydrologic and phosphorous budgets of lakes [abs.]: Annual Midwest Ground Water Conference, 30th, St. Paul, Minnesota, October 23-25, 1985 [Proceedings], p. 3. 
1985, Hydrologic factors affecting lake-level fluctuations in Big Marine Lake, Washington County, Minnes ota: U.S. Geological Survey Water-Resources Investigations Report 85-4176, 23 p.

1986, Errors in estimating ground-water components of hydrologic and phosphorus budgets of lakes, in Subitzky, Seymour, ed., Selected papers in hydrologic sciences 1986: U.S. Geological Survey Water-Suppl:' Paper 2310, p. 53-64.

1987. Effects of wetland channelization of storm runoff in Lambert Creek, Ramsey County, Minnesota: National Wetlands Symposium of Wetland Hydrology, Chicago, Illinois, September 16-18, 1987 [Proceedin?s], p. 130-136.

Brown, R.F., and Cotter, R.D., 1963, Water and the Minnesota Iron Range: U.S. Geological Survey, 16 p.

Brown, R.G., Patterson, G.L., and Stark, J.R., 1986, Ground-water and surface-water interaction in wetlands Comparisons and contrasts [abs.]: Wisconsin Section Annual Meeting, Wisconsin Dells, Wisconsin, April 3-4, 1986, Proceedings: American Water Resources Association, p. 1.

Brown, R.G., and Stark, J.R., 1989, Hydrologic and water quality characteristics of a wetland receiving wastew ter effluent in St. Joseph, Minnesota: Wetlands, v. 9, no. 2, p. 191-206.

Brown, R.G., and Stark, J.R., and Patterson, G.L., 1985, Ground-water and surface-water interactions in Minnesota and Wisconsin wetlands, in Hook, D.D., McKee, W.H., Jr., Smith, H.K., Gregory, J., Burrell, V.G., Jr., DeVee M.,R., Sojka, R.E., Gilberts, S., Banks, R., Stolzy, L.H., Brooks, C., Matthews, T.D., and Shear, T.H., The ecology and management of wetlands: Portland, Oregon, Timber Press, p. 176-180.

Byers, A.C., Wenzel, L.K., Laird, W.M., and Dennis, P.E., 1946, Ground water in the Fargo-Moorhead area, North Dakota and Minnesota: U.S. Geological Survey, 72 p.

Capel, P.D., 1990, Atmospheric deposition of herbicides in Minnesota [abs.]: Minnesota Water 1990_Facing Environmental Challenges of the 1990's, St. Paul, Minnesota, April 1990, Proceedings: Minnesota Water Resources Research, p. 27.

1990, Atmospheric deposition of herbicides in the midcontinental United States [abs.]: EOS, Transactions, American Geophysical Union, v. 71, no. 43, p. 1329.

-1990, A bibliography of atrazine and its simple degradation products in the environment: U.S. Geological Survey Open-File Report 89-613, 5 p.

-1991, Wet atmospheric deposition of herbicides in Minnesota, in Mallard, G.E., and Aronson, D.A., eds., U.S. Geological Survey Toxic Substances Hydrology Program_-Proceedings of the technical meeting, Monterey, California, March 11-15, 1991: U.S. Geological Survey Water-Resources Investigations Report 91-4034, p. 334337.

Capel, P.D., and Barbeau, D.S., 1991, Method for the systematic evaluation of organic chemical retention by s slid phase extraction columns, in Mallard, G.E., and Aronson, D.A., eds., U.S. Geological Survey Toxic Substances Hydrology Program-Proceedings of the technical meeting, Monterey, California, March 11-15, 1991: U.S Geological Survey Water-Resources Investigations Report 91-4034, p. 330-333.

CarIson, G.H., 1971, Flooded area of Lake St. Croix Beach, Minnesota: U.S. Geological Survey Open-File Reprrt, 4 p.

—1971, Flooded area of Lakeland Shores, Minnesota: U.S. Geological Survey Open-File Report, 5 p.

-1971, Flooded area of Montevideo, Minnesota: U.S. Geological Survey Open-File Report, 6 p.

-1991, Minnesota floods and drought, in Paulson, R.W., Chase, E.B., Williams, J.S., and Moody, D.W., compilers, National Water Summary 1988-89: U.S. Geological Survey Water-Supply Paper 2375, p. $345-352$. 
1994, Changes in 100-year flood discharge estimates with varying period of record on Minnesota streams [abs.]: Minnesota Water '94 Managing Minnesota's Rivers and Watersheds, Minneapolis, Minnesota, April 21-22, 1994 [Proceedings], p. 11.

Carlson, G.H., and Guetzkow, L.C., 1980, Flood-plain areas of the Mississippi River mile 866.8 to mile 888.0: U.S. Geological Survey Water-Resources Investigations Report 80-972, 8 sheets.

Carlson, G.H., and Gunard, K.T., 1979, Small stream flood investigations in Minnesota, October 1958 to September 1977: U.S. Geological Survey Open-File Report 79-1061, 194 p.

Carlson, G.H., Zandlo, J.A., Nindles, D.B., and Sium, Ogbazghi, 1990, Minnesota floods and drought, in Paulson, R.W., Chase, E.B., Roberts, R.S., and Moody, D.W., compilers, National Water Summary 1988-89: U.S. Geological Survey Water-Supply Paper 2375, p. 345-352.

Chang, Fu-Hsian, Hult, M.F., and Noben, N.N., 1987, Quantitative studies of biodegradation of petroleum and some model hydrocarbons in ground water and sediment environments, in Fairchild, D.M., ed., Ground-water quality and agricultural practices: Chelsea, Michigan, Lewis Publishers, p. 295-318.

Chang, Fu-Hsian, Noben, N.N., Brend, Daniel, and Hult, M.F., 1988, Microbial degradation of crude oil and some model hydrocarbons, in Ragone, S.E., ed., U.S. Geological Survey Program on toxic waste-ground-water contamination-Proceedings of the second technical meeting, Cape Cod, Massachusetts, October 21-25, 1985: U.S. Geological Survey Open-File Report 86-481, p. C33-C42.

Colby, V.C., 1964, Instructions for use of BM-54 and BM-60 bed-material samplers for the collection of samples to be analyzed for organic substances: Federal Inter-Agency Sedimentation Project, 3 p.

1965, Operating instructions for US DH-48 suspended-sediment hand sampler: Federal Inter-Agency Sedimentation Project Report J, 5 p.

Colby, V.C., and Witzgman, F.W., 1958, Operator's manual on the visual-accumulation tube method for sedimentation analysis of sands: Federal Inter-Agency Sedimentation Project Report K, 28 p.

-1962, Instructions for US P-61-A1 suspended-sediment sampler: Federal Inter-Agency Sedimentation Project, $9 \mathrm{p}$.

Collier, C.R., 1974, An approximation of sediment yields from watersheds in Minnesota, in Winter Meeting, Chicago, Illinois, December 10-13, 1974, Proceedings: American Society of Agricultural Engineers, 9 p.

Cotter, R.D., and Bidwell, L.E., 1966, Water resources of the Pomme de Terre River watershed, west-central Minnesota: U.S. Geological Survey Hydrologic Investigations Atlas HA-220, 4 sheets, scale 1:250,000.

1968, Water resources of the Lac qui Parle River watershed, southwestern Minnesota: U.S. Geological Survey Hydrologic Investigations Atlas HA-269, 4 sheets, scale 1:250,000.

Cotter, R.D., Bidwell, L.E., Oakes, E.L., and Hollenstein, G.H., 1966, Water resources of the Big Stone Lake watershed, west-central Minnesota: U.S. Geological Survey Hydrologic Investigations Atlas HA-213, 4 sheets, scale $1: 250,000$.

Cotter, R.D., BidwelI, L.E., VanVoast, W.A., and Novitzki, R.P., 1968, Water resources of the Chippewa River watershed, west-central Minnesota: U.S. Geological Survey Hydrologic Investigations Atlas HA-286, 4 sheets, scale $1: 250,000$.

Cotter, R.D., and Rogers, J.E., 1961, Exploratory drilling for ground water in the Mountain Iron-Virginia area, St. Louis County, Minnesota: U.S. Geological Survey Water-Supply Paper 1539-A, 13 p.

1964, Glacial geology of the Mountain Iron-Virginia-Eveleth area Mesabi Iron Range, Minnesota: U.S. Geological Survey Professional Paper 501-C, p. C144-C146. 
Cotter, R.D, and Yonng L.H., 1960, Municipal water supplies on the Mesabi and Vermillion Iron Ranges, northeastern Minnesota: U.S. Geological Survey, Ground Water Series Basic Data Release 1, 61 p.

Cotter, R.D, Yonng, H.I. Petri, L.R., and Prior, C.H., 1965, Ground and surface water in the Mesabi and Vermillion Iron Range area, northeastern Minnesota: U.S. Geological Survey Water-Supply Paper 1759-A, p. Al-A36.

1965, Water resources in the vicinity of municipalities on the central Mesabi Iron Range, northeastern Minnesota: U.S. Geological Survey Water-Supply Paper 1759-D, 20 p.

- 1965, Water resources in the vicinity of municipalities on the east-central Mesabi Iron Range, northeastern Minnesota: U.S. Geological Survey Water-Supply Paper 1759-E, 23 p.

1965, Water resources in the vicinity of municipalities on the eastern Mesabi Iron Range, northeastern Minnesota: U.S. Geological Survey Water-Supply Paper 1759-F, 27 p.

1965, Water resources in the vicinity of municipalities on the west-central Mesabi Iron Range, northeaste $n$ Minnesota: U.S. Geological Survey Water-Supply Paper 1759-C, 21 p.

1965. Water resources in the vicinity of municipalities on the western Mesabi Iron Range, northeastern Minnesota: U.S. Geological Survey Water-Supply Paper 1759-B, 24 p.

Cotter, R.D., Yoang, H.I. and Winter, T.C., 1964, Preliminary surficial geologic map of the Mesabi-Vermill:on Iron Range area northeastern Minnesota: U.S. Geological Survey Miscellaneous Geologic Investigations Map I403, 1 sheet, scale 1:125,000.

Cowdery, T.K. 1994, Nutrient concentrations near the water table of the Sheyenne Delta aquifer beneath croplend areas-Preliminary results from a Red River of the North Basin land-use study [abs.], in Sorenson, S.K., ed., Proceedings Abstracts - American Water Resources Association's Symposium on the National Water-Quality Assessment (NAWQA) Program, Chicago, Illinois, November 7-9, 1994: U.S. Geological Survey Open-Fi' ? Report 94-397, p. 7.

Cowdery, T.K., and Brigham, M.E., 1992, Baseflow dissolved-solids loads to streams of the Red River of the North Basin, South Dakota, North Dakota, and Minnesota [abs.]: Annual Midwest Ground-Water Conference, 37 $\mathrm{h}$, Souix Falls, South Dakota, October 14-16, 1992 [Proceedings], p. 38.

Cowdery, T.K, and Gofi, Karin, 1994, Nitrogen concentrations near the water table of the Sheyenne Delta aquifer beneath cropland areas, near Ransom and Richland Counties, North Dakota [abs.]: North Dakota Water-Quality Symposium, 4th biennial, Fargo, North Dakota, March 30-31, 1994, Proceedings: North Dakota State University Extension Service, p. 14.

1994, Nitrogen concentrations near the water table of the Sheyenne Delta aquifer beneath cropland areas, Ransom and Richland Counties, North Dakota, in North Dakota Water-Quality Symposium, 4th biennial, Fargo, North Dakota, March 30-31, 1994, Proceedings: North Dakota State University Extension Service, p. 89-102.

1994, Nutrient concentrations near the water table of the Sheyenne Delta aquifer beneath cropland areas, Ransom and Richland Counties, North Dakota [abs.]: Minnesota Water '94 Managing Minnesota's Rivers and Watersheds, Minneapolis, Minnesota, April 21-22, 1994 [Proceedings], p. 8-9.

Czarnecki, J.B., 1983, Fortran computer programs to plot and process aquifer pressure and temperature data: U.S. Geological Survey Water-Resources Investigations Report 83-4051, 50 p.

Delin, G.N., 1985, Confined-drift aquifers studied near the Pomme de Terre and Chippewa Rivers, west-central Minnesota: U.S. Geological Survey Open-File Report, 2 p.

1986, Confined-drift aquifers in Minnesota: U.S. Geological Survey Open-File Report 86-240, 2 p. 
1986. Hydrogeology of confined-drift aquifers in part of west-central Minnesota [abs.]: Annual Meeting NorthCentral Section of Geological Society of America, 20th, Kent, Ohio, April 24-25, 1986, Proceedings: Geological Society of America, p. 286.

1986, Hydrogeology of confined-drift aquifers near the Pomme de Terre and Chippewa Rivers, western Minnesota: U.S. Geological Survey Open-File Report 86-4098, 90 p.

- 1987, Evaluation of availability of water from drift aquifers near the Pomme de Terre and Chippewa Rivers, western Minnesota: U.S. Geological Survey Water-Resources Investigations Report 86-432 I, 53 p.

1987, Ground-water quality in a complex system of glacial-drift aquifers in west-central Minnesota [abs.], in Zaporozec, A., ed., Annual Midwest Ground Water Conference, 32nd, Madison, Wisconsin, October 28-30, 1987 [Proceedings].

1990, Effects of differing agricultural practices on concentrations of nitrate and atrazine in a sand-plain aquifer, western Minnesota [abs.]: EOS, Transactions, American Geophysical Union, v. 71, no. 43, p. 1329.

1990, Geohydrology and water quality of confined-drift aquifers in the Brooten-Belgrade area, west-central Minnesota: U.S. Geological Survey Water-Resources Investigations Report 88-4I24, 138 p.

1990, Hydrogeology and simulation of ground-water flow in the Rochester area, southeast Minnesota, 197888: U.S. Geological Survey Water-Resources Investigations Report 90-4081, 102 p.

1990, Hydrologic considerations for delineating ground water recharge areas for wells, Rochester, Minnesota [abs.]: Minnesota Water 1990 - Facing Environmental Challenges of the 1990's, St. Paul, Minnesota, April 1990, Proceedings: Minnesota Water Resources Research, p. 42-43.

1991, Simulation of effects of ground-water development on water levels in glacial-drift aquifers in the Brooten-Belgrade area, west-central Minnesota: U.S. Geological Survey Water-Resources Investigations Report $88-4193,66 \mathrm{p}$.

1993, The Minnesota Management Systems Evaluation Area (MSEA) project—An overview [abs.]: Annual Water Resources Conference, 26th, St. Paul, Minnesota, October 26-27, 1993, Proceedings: American Society of Civil Engineers.

Delin, G.N., and Almendinger, J.E., 1991, Delineation of recharge areas for selected wells in the St. Peter-Prairie du Chien-Jordan aquifer, Rochester, Minnesota: U.S. Geological Survey Open-File Report 90-397, 60 p.

- 1993, Delineation of recharge areas for selected wells in the St. Peter-Prairie du Chien-Jordan aquifer, Rochester, Minnesota: U.S. Geological Survey Water-Supply Paper 2397, 39 p.

Delin, G.N., Anderson, J.L., and Dowdy, R.H., 1991, Integrated hydrologic research at the northern cornbelt sandplain management system evaluation area, Minnesota, in Mallard, G.E., and Aronson, D.A., eds., U.S. Geological Survey Toxic Substances Hydrology Program-Proceedings of the technical meeting, Monterey, California, March 11-15, 1991: U.S. Geological Survey Water-Resources Investigations Report 91-4034, p. $214-$ 218.

1992. The Minnesota Management Systems Evaluation Area Project-Assessing the effects of agricultural practices on ground-water quality [abs.]: Minnesota Water Conference, St. Paul, Minnesota, February 13-14, 1992 [Proceedings].

1992. The Minnesota Management Systems Evaluation Area Project--Assessing the effects of agricultural practices on ground-water quality [abs.]: Minnesota Water '92 - Sustaining Water Resources in the ' 90 's and Beyond, Minneapolis, Minnesota, Proceedings: University of Minnesota Water-Resources Research Center. 
Delin, G.N., and Landon, M.K., 1993, Effects of focused recharge on the transport of agricultural chemicals at the Princeton, Minnesota, Management Systems Evaluation Area, 1991-92 [abs.]: Agricultural Research to Protect Water Quality, Minneapolis, Minnesota, February 21-24, 1993, Proceedings: Soil and Water Conservation Society, p. 210-214.

1993, Effects of focused recharge on the transport of agricultural chemicals at the Princeton, Minnesota Management Systems Evaluation Area, 1991-92: U.S. Geological Survey Open-File Report 93-42, 8 p.

1993, Effects of focused recharge on transport of agricultural chemicals at the Princeton, Minnesota Management Systems Evaluation Area, 1991-1992: U.S. Geological Survey Open-File Report 93-79, 2 p.

1993, Effects of topography on the transport of agricultural chemicals near Princeton, Minnesota, 1992 [ak $:$ ], in Morganwalp, D.W., and Aronson, D.A., compilers, U.S. Geological Survey Toxic Substances Hydrology Program-Abstracts of the technical meeting, Colorado Springs, Colorado, September 20-24, 1993: U.S. Geological Survey Open-File Report 93-454, p. 91.

1994, Effects of focused recharge on the transport of agricultural chemicals near Princeton, Minnesota, 1092 [abs.]: Minnesota Water '94-Managing Minnesota's Rivers and Watersheds, Minneapolis, Minnesota, April 21-22, 1994 [Proceedings], p. 9.

Delin, G.N., Landon, M.K., Anderson, J.L., and Dowdy, R.H., 1992, Hydrologic research at the Princeton, Minnesota Management Systems Evaluation Area: U.S. Geological Survey Open-File Report 92-107, 2 p.

1992, The Minnesota Management Systems Evaluation Area [abs.]: Agronomy Abstracts of 1992 Annual Meeting, Minneapolis, Minnesota, November 1-6, 1992, Proceedings: American Society of Agronomy, p. 322.

Delin, G.N., Landon, M.K., Healy, R.W., and Olsen, H.W, 1992, Preferential flow through the unsaturated zone beneath a corn field near Princeton, Minnesota [abs.]: Joint Spring Meeting of American Geophysical Union, Canadian Geophysical Union, and Mineralogical Society of America, Montreal, Canada, May 12-15, 1992, Proceedings: American Geophysical Union, p. 132.

1993, Spatial variability of unsaturated-zone properties in relation to topography in a sand-plain setting near Princeton, Minnesota [abs.], in Morganwalp, D.W., and Aronson, D.A., compilers, U.S. Geological Survey Toxic Substance Hydrology Program-Abstracts of the technical meeting, Colorado Springs, Colorado, September 20-24, 1993: U.S. Geological Survey Open-File Report 93-454, p. 92.

1994, Spatial distribution of unsaturated-zone properties in relation to topography near Princeton. Minnesota [abs.]: Minnesota Water '94-Managing Minnesota's Rivers and Watersheds, Minneapolis, Minnesota, April 21-22, 1994 [Proceedings], p. 9.

Delin, G.N., Landon, M.K., Lamb, J.A., and Anderson, J.L., 1994, Characterization of the hydrogeology and water quality at the Management Systems Evaluation Area near Princeton, Minnesota, 1991-92: U.S. Geological Survey Water-Resources Investigations Report 94-4149, 54 p.

1994, Hydrogeologic and water-quality data used to characterize the Management Systems Evaluation Area near Princeton, Minnesota, 1991: U.S. Geological Survey Open-File Report 94-337, 42 p.

Delin, G.N., and Woodward, D.G., 1984, Hydrogeologic setting and potentiometric surfaces of regional aquifers in the Hollandale Embayment, southeastern Minnesota, 1970-80: U.S. Geological Survey Water-Supply Pape* 2219 , p. 56.

Diedrich, M.M., and Jannis, J.A., 1980, Status of projects in Minnesota, fiscal year 1980: U.S. Geological Sur'ey, $99 \mathrm{p}$.

1981, Status of projects in Minnesota, fiscal year 1981: U.S. Geological Survey, 58 p. 
Druffel, Leroy, Emmett, W.W., Schneider, V.R., and Skinner, J.V., 1976, Laboratory hydraulic calibration of the Helley-Smith bed-load-sediment sampler: U.S. Geological Survey Open-File Report 76-752, 63 p.

Ehrlich, G.G., Georlitz, D.F., Godsy, E.M., and Hult, M.F., 1982, Degradation of phenolic contaminants in ground water by anaerobic bacteria St. Louis Park, Minnesota: Ground Water, v. 20, no. 6, p. 703-710.

Ericson, D.W., Holmen, O.O., and Latkovich, V.J., 1980, Flood of April-May 1979 in Red River of the North Basin, North Dakota and Minnesota: U.S. Geological Survey Water-Resources Investigations Report 80-1176, 2 sheets.

Ericson, D.W., Lindholm, G.F., and Helgesen, J.O., 1974, Water resources of the Rum River watershed, eastcentral Minnesota: U.S. Geological Survey Hydrologic Investigations Atlas HA-509, 3 sheets, scales 1:250,000 and $1: 500,000$.

- 1976, Water resources of the Rainey Lake watershed, northeastern Minnesota: U.S. Geological Survey Hydrologic Investigations Atlas HA-556, 2 sheets, scale 1:1,000,000.

Farrell, D.F., Broussard, W.L., Anderson, H.W., Jr., and Hult, M.F., 1975, Water resources of the Cedar River watershed, southeastern Minnesota: U.S. Geological Survey Hydrologic Investigations Atlas HA-552, 3 sheets, scale $1: 250,000$.

Feth, J.H., 1965, Preliminary map of the conterminous United States showing depth to and quality of shallowest ground water containing more than 1,000 parts per million dissolved solids: U.S. Geological Survey Hydrologic Investigations Atlas HA-199, 31 p., 2 sheets, scale 1:3,168,000.

Ficke, J.F., and Hawkinson, R.O., 1975, The National Stream Quality Accounting Network (NASQAN)-Some questions and answers: U.S. Geological Survey Circular 719, 23 p.

Giacomini, E.G., Wolf, R.J., Payne, G.A., and Adolphson, D.G., 1980, Hydrologic characteristics of Elim, Skunk, and Deer Creeks, Upper Nemadji River Basin, Minnesota: U.S. Geological Survey Open-File Report 80-47, 65 p.

Glysson, G.D., and Skinner, J.V., 1990, Relation between the national handbook of recommended methods for water data acquisition and ASTM standards, in Hall, J.R., and Douglas, G.D., eds., Monitoring Water in the 1990'sMeeting New Challenges: Philadelphia, Pennsylvania, American Society for Testing and Materials, p. 291-300.

Goldstein, R.M., Simon, T.P., Bailey, P.A., Ell, Michael, Pearson, Eric, Schmidt, Konrad, and Enblom, J.W., 1994, Concepts for an index of biotic integrity for streams of the Red River of the North Basin [abs.]: North Dakota Water-Quality Symposium, 4th biennial, Fargo, North Dakota, March 30-31, 1994, Proceedings: North Dakota State University Extension Service, p. 19.

- 1994. Concepts for an index of biotic integrity for streams of the Red River of the North Basin, in North Dakota Water-Quality Symposium, 4th biennial, Fargo, North Dakota, March 30-31, 1994, Proceedings: North Dakota State University Extension Service, p. 169-180.

Greeson, P.E., ed., 1979, A supplement to methods for collection and analysis of aquatic biological and microbiological samples: U.S. Geological Survey Techniques of Water-Resources Investigations, book 5, chap. A4, 92 p.

Groschen, G.E., and Alexander, E.C., Jr., 1981, Geochemistry of Williams Lake, Hubbard County, Minnesota [abs.]: EOS, Transactions, American Geophysical Union, v. 63, no. 33, p. 613.

1982, Geochemistry of Williams Lake, Hubbard County, Minnesota [abs.]: EOS, Transactions, American Geophysical Union, v. 63, no. 33, p. 613.

Guetzkow, L.C., 1973, Small stream flood investigations in Minnesota, October 1958 to September 1971: U.S. Geological Survey Open-File Report, 159 p. 
1977, Techniques for estimating magnitude and frequency of floods in Minnesota: U.S. Geological Survey Water-Resources Investigations Report 77-31, 33 p.

Guetzkow, L.C., and Carlson, G.H., 1969, Small stream flood investigations in Minnesota, October 1958 to September 1967: U.S. Geological Survey Open-File Report, 174 p.

1973, Flood-plain areas of the lower Minnesota River: U.S. Geological Survey Open-File Report 74-15, 12 sheets.

Guetzkow, L.C., and Gunard, K.T., 1967, Small stream flood investigations in Minnesota, October 1958 to September 1965: U.S. Geological Survey Open-File Report, 162 p.

-1975, Small stream flood investigations in Minnesota, October 1958 to September 1973: U.S. Geological Survey Open-File Report, 161 p.

1977, Small stream flood investigations in Minnesota October 1958 to September 1975: U.S. Geological Survey Open-File Report 77-39, 161 p.

Gunard, K.T., 1971, Flooded area of St. Mary's Point, Minnesota: U.S. Geological Survey Open-File Report, $\epsilon$ p. 1985, Minnesota surface-water resources, in Woody, D.W., Chase, E.B., and Aronson, D.A., compilers, National Water Summary 1985: U.S. Geological Survey Water-Supply Paper 2300, p. 285-294.

Gunard, K.T., and Guetzkow, L.C., 1971, Small stream flood investigations in Minnesota, October 1958 to September 1969: U.S. Geological Survey Open-File Report, 174 p.

Gunard, K.T., and Smith, C.J., 1982, Small stream flood investigations in Minnesota October 1958 to September 1980: U.S. Geological Survey Open-File Report 82-433, 221 p.

Guo, Lifeng, Alexander, E.C. Jr., Landon, M.K., Delin, G.N., and Regan, C.P., 1994, Geochemical characteri tics and transport of agricultural leachates in a surficial sand and gravel aquifer near Princeton, Minnesota, 1991-92 [abs.]: 1993 Fall Meeting, San Francisco, California, December 6-10, 1993, Proceedings: American Geophysical Union, p. 269.

Guswa, J.H., Siegel, D.I., and Gillies, D.C., 1982, Preliminary evaluation of the ground-water-flow system in the Twin Cities metropolitan area, Minnesota: U.S. Geological Survey Water-Resources Investigations Report 82$44,65 \mathrm{p}$.

Guy, H.P., 1970, Sediment problems in urban areas: U.S. Geological Survey Circular 601-E, 8 p.

Hatch, J.R., and Morey, G.B., 1984, Hydrocarbon source rock evaluation--Solo Church Formation (middle Proterozoic, Keeweenawan Supergroup), southeastern Minnesota: U.S. Geological Survey Open-File Report 84$554,17 \mathrm{p}$.

Hatfield, J.L., Anderson, J.L., Alberts, E.E., Prato, Tony, Watts, D.G., Ward, Andrew, Delin, G.N., and Sw?nk, Robert, 1993, Management Systems Evaluation Areas-An overview: Agricultural Research to Protect Water Quality, Minneapolis, Minnesota, February 21-24, 1993, Proceedings: Soil and Water Conservation Societ"', p. $1-10$.

Have, M.R., 1975, A water-quality assessment of the Burham Creek watershed, Polk County, Minnesota: U.S. Geological Survey Open-File Report 75-647, 15 p.

- 1975, Some limnological aspects of 20 selected lakes in Eagan and Apple Valley, Minnesota: U.S. Geolopical Survey Open-File Report 75-528, 44 p.

1980, Water quality of Rogers Lake, Dakota County, Minnesota: U.S. Geological Survey Water-Resources lnvestigations Report 80-5, 35 p. 
1991, Selected water-quality characteristics in the Upper Mississippi River Basin, Royalton to Hastings, Minnesota: U.S. Geological Survey Water-Resources Investigations Report 88-4053, 152 p.

1991, Streamflow entering and leaving Lake Bemidji, Beltrami County, Minnesota, July 1989-September 1989: U.S. Geological Survey Open-File Report 91-499, 25 p.

Have, M.R., Payne, G.A., and Ayers, M.A., 1981, Water quality of Alimagnet, Farquar, and Long Lakes in Apple Valley, Minnesota: U.S. Geological Survey Water-Resources Investigations Report 81-40, 38 p.

Have, M.R., and Tornes, L.H., 1987, Water quality data for Orwell Reservoir and Otter Tail River near Fergus Falls, Minnesota: U.S. Geological Survey Open-File Report 87-537, 48 p.

Hein, M.D., 1982, Status of water-resources projects in Minnesota, fiscal year 1982: U.S. Geological Survey, 61 p.

Helgesen, J.O., 1971, Appraisal of ground water for irrigation in the Little Falls area, Morrison County, Minnesota: U.S. Geological Survey Open-File Report, 54 p.

1973, Appraisal of ground water for irrigation in the Little Falls area, Morrison County, Minnesota: U.S. Geological Survey Water-Supply Paper 2009-D, $40 \mathrm{p}$.

1977, Ground-water appraisal of the Pineland Sands area, central Minnesota: U.S. Geological Survey WaterResources Investigations Report 77-102, 49 p.

Helgesen, J.O., Ericson, D.W., and Lindholm, G.F., 1975, Water resources of the Mississippi and Sauk Rivers watershed, central Minnesota: U.S. Geological Survey Hydrologic Investigations Atlas HA-534, 3 sheets.

Helgesen, J.O., and Lindholm, G.F., 1973, Geology and water-supply potential of the Anoka Sand Plain aquifer, Minnesota: U.S. Geological Survey Open-File Report, 19 p.

-1977, Geology and water-supply potential of the Anoka Sand Plain aquifer, Minnesota: Minnesota Department of Natural Resources Technical Paper 6, $17 \mathrm{p}$.

Helgesen, J.O., Lindholm, G.F., Broussard, W.L., and Ericson, D.W., 1973, Water resources of the Kettle River watershed, east-central Minnesota: U.S. Geological Survey Hydrologic Investigations Atlas HA-437, 4 sheets, scale $1: 250,000$.

Helgesen J.O., Lindholm, G.F., and Ericson, D.W., 1975, Water resources of the Lake of the Woods watershed, north-central Minnesota: U.S. Geological Survey Hydrologic Investigations Atlas HA-544, 2 sheets, scale $1: 500,000$.

-1976, Water resources of the Little Rock River watershed, northeastern Minnesota: U.S. Geological Survey Hydrologic Investigations Atlas HA-551, 2 sheets, scale 1:500,000.

Herb, W.J., 1989, Minnesota District Water Resources Division—-Information and technical assistance, in Agrichemicals and Ground Water Protection—-Resources and Strategies for State and Local Management, St. Paul, Minnesota, October 24-25, 1988 [Proceedings], p. 93-97.

Hicks, J.K., 1974, Coon Rapids pool hydrographic study: U.S. Geological Survey Open-File Report, 6 p.

Horn, M.A., 1981, Data for water resources management in Minnesota, in Allee, D.J., Dworsky, L.B., and North, R.M., eds., Unified River Basin Management-Stage II, American Water Resources Association Symposium, Atlanta, Georgia, October 4-8, 1981, Proceedings: American Water Resources Association, p. 429-441.

1983, Ground-water-use trends in the Twin Cities metropolitan area, Minnesota 1880-1980: U.S. Geological Survey Water-Resources Investigations Report 83-4033, 37 p.

- 1984, Annual ground-water use in the Twin Cities metropolitan area, Minnesota 1970-79: U.S. Geological Survey Open-File Report 84-577, 130 p. 
1986, Development of a water-use data system in Minnesota: U.S. Geological Survey Water-Resources Investigations Report 85-4306, 59 p.

Hotchkiss, R.H.. 1991, Particle size distributions by Pipet and sedigraph, in Ian, S.S., and Kuo, Y.H., eds., Federal Inter-Agency Sedimentation Conference, 5th. Las Vegas, Nevada, March 18-21, 1991, Proceedings: Federal Inter-Agency Sedimentation Project, v. 1, p. 6-47-6-54.

Hoyer, M.C., Hallgren, J.P., Uebel., M.H., Delin, G.N., Eisenreich, S.J., and Sterling, R.L., 1994, University' of Minnesota Aquifer Thermal-Energy Storage (ATES) project report on the third long-term cycle: University of Minnesota, $125 \mathrm{p}$.

Hubbell, D.W., Stevens, H.H., Jr., Skinner, J.V., and Beverage, J.P., 1981, Recent refinements in calibrating liadload samplers, in Water Forum '81, San Francisco, California, August 10-14, 1981, Proceedings: American Society of Civil Engineers, v. 1, p. 128-140.

1983, New approach to calibrating bed-load samplers: Journal of Hydraulic Engineering, v. III, no. 4, p. 677 694.

- 1987, Laboratory data on coarse-sediment transport for bed-load-sampler calibrations: U.S. Geological Survey Water-Supply Paper 2299, 30 p.

Hult, M.F., 1979, Design of a network for monitoring ground-water quality in Minnesota: U.S. Geological Survey Open-File Report 79-1164, 44 p.

1984, Assessment of ground-water contamination by coal-tar derivatives, St. Louis Park area Minnesota: U.S. Geological Survey Open-File Report 84-867, 57 p.

1984, Ground-water contamination by crude oil at the Bemidji, Minnesota research site-An introductior. in Hult, M.F.. ed., Ground-water contamination by crude oil at the Bemidji, Minnesota research site-U.S. Geological Survey toxic waste ground-water contamination study: U.S. Geological Survey Water-Resource. Investigations Report 84-4188, p. 1-15.

1986, Transport and oxidation of hydrocarbon vapors in a shallow aquifer [abs.]: EOS, Transactions, Ameriman Geophysical Union, v. 67, no. 16, p. 279.

1987, Measurement of hydrocarbon vapors and degradation products in the unsaturated zone [abs.]: EOS, Transactions, American Geophysical Union, v. 68, no. 16, p. 327.

1987, Microbial oxidation of petroleum vapors in the unsaturated zone [abs.], in Franks, B.J., ed., U.S. Geological Survey program on toxic waste - ground-water contamination-Proceedings of the third technical meeting, Pensacola, Florida, March 23-27, 1987: U.S. Geological Survey Open-File Report 87-109 p. C25-C26.

1987, Movement and fate of crude-oil in contaminants in the subsurface environment at Bemidji, Minnesota, Chapter C, in Franks, B.J., ed., U.S. Geological Survey program on toxic waste ground-water contaminaticnProceedings of the third technical meeting, Pensacola, Florida, March 23-27, 1987: U.S. Geological Survey Open-File Report 87-109, p. C3-C4.

1989, Mobilization, transport, and fate of hydrocarbon vapors in the unsaturated zone [abs.], in Mallard, G.E., and Ragone, S.E., eds., U.S. Geological Survey Toxic Substances Hydrology Program Proceedings of the technical meeting, Phoenix, Arizona, September 26-30, 1988: U.S. Geological Survey Water-Resources Investigations Report 88-4220, p. 53.

1989, Subsurface contamination at the Bemidji, Minnesota research site [abs.], in Mallard, G.E., and Ragone, S.E., eds., U.S. Geological Survey Toxic Substances Hydrology Program-Proceedings of the technical meeting, Phoenix, Arizona, September 26-30, 1988: U.S. Geological Survey Water-Resources Investigations Report 88-4220, p. 3. 
1991, Overview of research on contamination of the subsurface by crude oil at the Bemidji, Minnesota toxic substances research site, in Mallard, G.E., and Aronson, D.A., eds., U.S. Geological Survey Toxic Substances Hydrology Program-Proceedings of technical meeting, Monterey, California, March 11-15, 1991: U.S. Geological Survey Water-Resources Investigations Report 91-4034, p. 611-613.

Hult, M.F., ed., 1984, Ground-water contamination by crude oil at the Bemidji, Minnesota research site-U.S. Geological Survey toxic waste-ground-water contamination study: U.S. Geological Survey Water-Resources Investigations Report 84-4188, $107 \mathrm{p}$.

Hult, M.F., Chang, F.H., and Pfannnkuch, H.O., 1986, Microbial oxidation of petroleum vapors in the unsaturated zone, in Chapman Conference on Microbial Processes in the Transport, Fate and In-situ Treatment of Subsurface Contaminants, Snowbird, Utah, October 1-3, 1986: American Geophysical Union Chapman Meeting Abstracts, p. 23-24.

Hult, M.F., and Grabbe, R.R., 1988, Distribution of gases and hydrocarbon vapors in the unsaturated zone, in Ragone, S.E., ed., U.S. Geological Survey program on toxic waste-ground-water contamination-Proceedings of the second technical meeting, Cape Cod, Massachusetts, October 21-25, 1985: U.S. Geological Survey OpenFile Report 86-481, p. C21-C25.

Hult, M.F., Landon, M.K., and Pfannkuch, H.O., 1991, Field validation of conceptual models of mobilization and transport of volatile petroleum derivatives in the unsaturated zone near Bemidji, Minnesota, in Mallard, G.E., and Aronson, D.A., eds., U.S. Geological Survey Toxic Substances Hydrology Program-Proceedings of technical meeting, Monterey, California, March 11-15, 1991: U.S. Geological Survey Water-Resources Investigations Report 91-4034, p. 621-626.

Hult, M.F., and Schoenberg, M.E., 1981, Preliminary evaluation of ground-water contamination by coal-tar derivatives, St. Louis Park area, Minnesota: U.S. Geological Survey Water-Resources Investigations Report 81$72,53 \mathrm{p}$.

1984, Preliminary evaluation of ground-water contamination by coal-tar derivatives, St. Louis Park area, Minnesota: U.S. Geological Survey Water-Supply Paper 2211, 53 p.

Jannis, J.A., 1983, Status of water-resources projects in Minnesota, fiscal year 1983: U.S. Geological Survey, 74 p.

1984, Status of projects in Minnesota fiscal year 1984: U.S. Geological Survey Open-File Report, 84 p.

1986, Water-resources activities of the U.S. Geological Survey in Minnesota, fiscal year 1985: U.S. Geological Survey Open-File Report 86-133, 83 p.

Jannis, J.A., and Diedrich, M.M., 1979, Status of projects in Minnesota, fiscal year 1979: U.S. Geological Survey, $79 \mathrm{p}$.

Jaques, J.E., and Lorenz, D.L., 1988, Techniques for estimating the magnitude an frequency of floods in Minnesota: U.S. Geological Survey Water-Resources Investigations Report 87-4170, 48 p.

Jones, J.R., Akin, P.D., and Schneider, Robert, 1963, Geology and ground-water conditions in the southern part of the Camp Ripley Military Reservation, Morrison County, Minnesota: U.S. Geological Survey Water-Supply Paper 1669-A, $32 \mathrm{p}$.

Komor, S.C., 1992, Bidirectional sulfate diffusion in saline-lake sediments--Evidence from Devil's Lake: Geology, v. 20 , no. 4 , p. $319-322$.

1992, Nitrate in Minnesota sand-plain aquifers [abs.]: Joint Spring Meeting of American Geophysical Union, Canadian Geophysical Union, and Mineralogical Society of America, Montreal, Canada, May 12-15, 1992,

Proceedings: American Geophysical Union, p. 125. 
1993, Stable isotopes used to evaluate soil-water movements [abs.]: American Geophysical Union Spring Meeting, Baltimore, Maryland, May 24-28, 1993, Proceedings: American Geophysical Union, p. 140.

1994, Bottom-sediment chemistry in Devil's Lake, northeast North Dakota: Sedimentology and Geochemistry of Modern and Ancient Saline Lakes, no. 50, p. 21-32.

-1994, Geochemistry and hydrology of a calcareous fen within the Savage Fen wetlands complex, Minnesota, USA: Geochimica et Cosmochimica Acta, v. 58, no. 16, p. 3353-3367.

- 1994, Geochemistry and hydrology of Savage Fen, a calcareous fen in the Minnesota River Valley [abs.]: Minnesota Water '94 Managing Minnesota's Rivers and Watersheds, Minneapolis, Minnesota, April 21-22, 1994 [Proceedings], p. 9.

1994, Petrography and chemistry of calcite in the KTB borehole, Germany [abs.]: International Symposiur on the Observation of the Continental Crust Through Drilling, 7th, Sante Fe, New Mexico, April 25-30, 1994 [Proceedings].

Komor, S.C., and Anderson, H.W., Jr., 1993, Nitrogen isotopes as indicators of nitrate sources in Minnesota srndplain aquifers: Ground Water, v. 31, no. 2, p. 260-270.

Komor, S.C., and Emerson, D.G., 1992, Atrazine and bromide movement through the unsaturated sand plains at sites in Minnesota and North Dakota [abs.]: 1992 North Dakota Water Quality Symposium, Bismarck, North Dakota, March 25-26, 1992, Proceedings: North Dakota State University Extension Service.

1994, Movements of water, solutes, and stable isotopes in the unsaturated zones of two sand plains in the Ufper Midwest: Water Resources Research, v. 30, no. 2, p. 253-267.

LaBaugh, J.W., Groschen, G.E., and Winter, T.C., 1981, Limnological and geochemical survey of Williams Lake, Hubbard County, Minnesota: U.S. Geological Survey Water-Resources Investigations Report 81-41, 38 p.

Lamb, J.A., Anderson, J.L., Dowdy, R.H., and Delin, G.N., 1992, Northern cornbelt sandplain MSEA [abs.]: Minnesota Water ' 92 - Sustaining Water Resources in the '90's and Beyond, Minneapolis, Minnesota, Proceedings: University of Minnesota Water-Resources Research Center.

Landon, M.K., Delin, G.N., Guo, Lifeng, Regan, C.P., Anderson, J.L., and Dowdy, R.H., 1992, Ground-wat?r quality at the Management Systems Evaluation Area near Princeton, Minnesota, 1991 [abs.]: Annual Midwest Ground Water Conference, 37th, Souix Falls, South Dakota, October 14-16, 1992 [Proceedings], p. 30.

Landon, M.K., Delin, G.N., Guo, Lifeng, Regan, C.P., Lamb, J.A., Dowdy, R.H., and Anderson, J.L., 1993, Occurrence of agricultural chemicals in ground water at the Princeton, Minnesota Management Systems Evaluation Area: Agricultural Research to Protect Water Quality, Minneapolis, Minnesota, February 21-24, 1993, Proceedings: Soil and Water Conservation Society, p. 434-438.

Landon, M.K., Delin, G.N., Komor, S.C., and Regan, C.P., 1994, Stable isotopes and major anions as tracers of recharge water to a sand and gravel aquifer, central Minnesota [abs.]: EOS, Transactions, American Geophysical Union, v. 73, no. 44, p. 277.

Landon, M.K., Delin, G.N., Lamb, J.A., Anderson, J.L., and Dowdy, R.H., 1994, Impacts of farming systems on ground-water quality at the Princeton, Minnesota, Management Systems Evaluation Area (MSEA)1991-19?2 [abs.]: Minnesota Water '94 Managing Minnesota's Rivers and Watersheds, Minneapolis, Minnesota April 2122, 1994 [Proceedings], p. 6. 
Landon, M.K., Delin, G.N., Lamb, J.A., Dowdy, R.H., and Anderson, J.L.. 1993, Effects of farming systems on ground water quality at the Princeton, Minnesota Management Systems Evaluation Area, 1991 [abs.], in Morganwalp, D.W., and Aronson, D.A., compilers, U.S. Geological Toxic Substances Hydrology ProgramAbstracts of the technical meeting, Colorado Springs, Colorado: U.S. Geological Survey Open-File Report 93454, p. 63.

1994, Effects of farming systems on concentrations of nitrate in ground water at the Princeton, Minnesota Management Systems Evaluation Area (MSEA), 1991-1992 [abs.]: EOS, Transactions, American Geophysical Union, v. 75, no. 19, p. 157.

Landon, M.K., Delin, G.N., Lamb, J.A., and Guo, Lifeng, 1993, Ground-water quality at the Management Systems Evaluation Area (MSEA) near Princeton, Minnesota, 1991: U.S. Geological Survey Open-File Report 93-43, 8 p.

-1993. Ground-water quality at the Management Systems Evaluation Area near Princeton, Minnesota, 1991:

U.S. Geological Survey Open-File Report 93-80, 2 p.

Landon, M.K., and Hult, M.F., 1991, Evolution of physical properties and composition of a crude oil spill, in Mallard, G.E., and Aronson, D.A., eds., U.S. Geological Survey Toxic Substances Hydrology ProgramProceedings of the technical meeting, Monterey, California, March 11-15, 1991: U.S. Geological Survey WaterResources Investigations Report 91-4034, p. 641-645.

-1992, Source mass balance calculated from changes in physical properties and composition of spilled crude oil in the subsurface near Bemidji, Minnesota: EOS, Transactions, American Geophysical Union. v. 73, no. 14, p. 132-133.

1993, Source mass balance calculated from changes on composition of spilled crude oil in the subsurface near Bemidji, Minnesota [abs.], in Morganwalp, D.W., and Aronson, D.A., compilers, U.S. Gcological Survey Toxic Substances Hydrology Program-Abstracts of the technical meeting, Colorado Springs, Colorado, September 20-24, 1993: U.S. Geological Survey Open-File Report 93-454, p. 105.

Langford, R.H., 1964, Chemical quality of the water resources Kittson, Marshall, and Roseau Counties, Minnesota: Unpublished report on file with U.S. Geological Survey in Mounds View, Minnesota, 168 p.

Larson, S.P., 1976, An appraisal of ground water for irrigation in the Appleton area, west-central Minnesota: U.S. Geological Survey Water-Supply Paper 2039-B, 34 p.

Larson, S.P., Mann, W.B., IV, Steele, T.D., and Susag, R.H., 1974, Time-trend and river-reach assessments in water quality of the Mississippi River, Minneapolis-St. Paul, metropolitan area, Minnesota [abs.]: EOS, Transactions, American Geophysical Union, v. 55, no. 12, p. 1114.

1976, Graphic and analytical methods for assessments of stream-water quality-Mississippi River in the Minneapolis-St. Paul metropolitan area, Minnesota: U.S. Geological Survey Water-Resources Investigations Report 76-94, $55 \mathrm{p}$.

Larson, S.P., McBride, M.S., and Wolf, R.J., 1975, Digital models of a glacial outwash aquifer in the Pearl-Sallie Lakes area, west-central Minnesota: U.S. Geological Survey Water-Resources Investigations Report 75-40,39 p.

Larson-Higdem, D.C., 1976, Map showing altitude of the bedrock surface in Minnesota: U.S. Geological Survey Open-File Report 76-788, 1 sheet.

Larson-Higdem, D.C., Larson, S.P., and Norvitch, R.F., 1975, Configuration of the water table and distribution of downward leakage to the Prairie du Chien-Jordan aquifer in the Minneapolis-St. Paul metropolitan area, Minnesota: U.S. Geological Survey Open-File Report 75-342, 33 p.

Latkovitch, V.J., 1979, Flood of July 5-7, 1978 on the South Fork Zumbro River at Rochester, Minnesota: U.S. Geological Survey Water-Resources Investigations Report 79-1583, 1 sheet. 
1979, Hydrologic data for floods of July 1978 in southeast Minnesota and southwest Wisconsin: U.S. Geological Survey Open-File Report 79-I 166, 29 p.

Liesch, B.A.,1961, Geohydrology of the Jordan aquifer in the Minneapolis-St. Paul area, Minnesota: Minnesota Department of Conservation, Division of Waters Technical Paper 2, $24 \mathrm{p}$.

Liesch, B.A., and Norvitch, R.F., 1963, Geology and ground-water conditions in the Chisholm-Dewey Lake area, St. Louis County, Minnesota: Unpublished report on file with U.S. Geological Survey in Mounds View, Minnesota, $68 \mathrm{p}$.

Lindgren, R.J., 1990, Simulation of ground-water flow in the Prairie du Chien-Jordan and overlying aquifers near the Mississippi River, Fridley, Minnesota: U.S. Geological Survey Water-Resources Investigations Report 90-4165, $152 \mathrm{p}$.

Lindholm, G.F., 1968, Geology and water resources of the Hibbing area, northeastern Minnesota: U.S. Geological Survey Hydrologic Investigations Atlas HA-280, 3 sheets, scale 1:24,000.

1970, An appraisal of ground water for irrigation in the Wadena area, central Minnesota: U.S. Geological Survey Water-Supply Paper 1983, 56 p.

1980, Ground-water appraisal of sand plains in Benton, Sherburne, Stearns, and Wright Counties, central Minnesota: U.S. Geological Survey Water-Resources Investigations Report 80-1285, 103 p.

Lindholm, G.F., Ericson, D.W., Broussard, W.L., and Hult, M.F., 1979, Water resources of the St. Louis Rivir watershed, northeastern Minnesota: U.S. Geological Survey Hydrologic Investigations Atlas HA-586, 3 she

Lindholm, G.F., Farrell, D.F., and Helgesen, J.O., 1974, Water resources of the Crow River watershed, southcentral Minnesota: U.S. Geological Survey Hydrologic Investigations Atlas HA-528, 3 sheets, scale 1:500,C 0.

Lindholm, G.F., Helgesen, J.O., Broussard, W.L., and Farrell, D.F., 1974, Water resources of the lower St. Croix River watershed, east-central Minnesota: U.S. Geological Survey Hydrologic Investigations Atlas HA-490, 3 sheets, scales $1: 250,000$ and $1: 500,000$.

1974, Water resources of the Snake River watershed, east-central Minnesota: U.S. Geological Survey Hydrologic Investigations Atlas HA-488, 3 sheets, scales 1:250,000 and 1:500,000.

Lindholm, G.F., Helgesen, J.O., and Ericson, D.W., 1976, Water resources of the Fork River watershed, north central Minnesota: U.S. Geological Survey Hydrologic Investigations Atlas HA-549, 2 sheets, scale 1:500,000.

Lindholm, G.F., and Norvitch, R.F., 1976, Ground water in Minnesota: U.S. Geological Survey Open-File Refort 76-354, $100 \mathrm{p}$.

1976, Remote sensing as an aid in water-resources studies in Minnesota: U.S. Geological Survey Open-File Report 76-213, $63 \mathrm{p}$.

Lindholm, G.F., Oakes, E.L., Ericson, D.W., and Helgesen, J.O., 1972, Water resources of the Crow Wing River watershed, central Minnesota: U.S. Geological Survey Hydrologic Investigations Atlas HA-380, 4 sheets, scale 1:250,000.

Linskov, K.L., 1975, Data summary of June-July 1975 floods in eastern North Dakota and northwestern Minnes ?ta: U.S. Geological Survey Open-File Report 75-565, 15 p.

1977, Low-flow characteristics of Minnesota streams: U.S. Geological Survey Water-Resources Investigations Report 77-48, 197 p. 
Lorenz, D.L., 1990, A method for describing stream-drainage system topology in a geographic information system [abs.], in Balthrop, B.H., and Baker, E.G., compilers, U.S. Geological Survey National Computer Technology Meeting-Program and abstracts, San Antonio, Texas, May 7-11, 1990: U.S. Geological Survey Open-File Report 90-161, p. 22.

1991, Describing stream-drainage systems using a geographic information system [abs.]: Water Management of River Systems, New Orleans, Louisiana, September 8-13, 1991, Proceedings: American Water Resources Association, p. 285-286.

1992, Integrating and aggregating data from stream-drainage systems using a geographic information system, in Wiltshire, D.A., ed., Selected papers in applied computer sciences 1992: U.S. Geological Survey Bulletin 2016, p. D1-D7.

1992, Using a geographic information system to describe the environmental setting of the Red River of the North Basin [abs.], in Balthrop, B.H., and Baker, E.G., eds., U.S. Geological Survey National Computer Technology Meeting_-Program and abstracts, Norfolk, Virginia, May 17-22, 1992: U.S. Geological Survey Open-File Report 92-64, p. 21.

1994, Use of remotely sensed data to characterize vegetation in the Red River of the North Basin, Minnesota, North Dakota, and South Dakota [abs.], in Balthrop, B.H., and Baker, E.G., compilers, U.S. Geological Survey National Computer Technology Meeting-Program and abstracts, New Orleans, Louisiana April 10-15, 1994: U.S. Geological Survey Open-File Report 94-52, p. 27.

Lorenz, D.L., and Payne, G.A., 1989, Selected data describing stream subbasins in the Redwood River Basin, southwestern Minnesota: U.S. Geological Survey Open-File Report 89-405, 5 p.

1991, Selected data for stream subbasins in the Le Sueur River Basin, south-central Minnesota: U.S. Geological Survey Open-File Report 91-62, 8 p.

1991, Selected data for stream subbasins in the Watonwan River Basin, south-central Minnesota: U.S. Geological Survey Open-File Report 91-61, 7 p.

- 1992, Physical characteristics of stream subbasins in the Blue Earth River Basin, south-central Minnesota and north-central Iowa: U.S. Geological Survey Open-File Report 91-512, 10 p.

1994, Physical characteristics of stream subbasins in the Pomme de Terre River Basin, west-central Minnesota: U.S. Geological Survey Open-File Report 93-47, 8 p.

Lorenz, D.L., and Stark, J.R., 1987, Evaluation of gradient-control options for contaminated ground water in the St. Peter aquifer, St. Louis Park, Minnesota [abs.], in Zaporozec, A., ed., Annual Midwest Ground Water Conference, 32nd, Madison, Wisconsin, October 28-30, 1987 [Proceedings].

1990, Simulation of ground-water flow in the St. Peter aquifer in an area contaminated by coal-tar derivatives, St. Louis Park, Minnesota: U.S. Geological Survey Water-Resources Investigations Report 90-4150, 37 p.

Lorenz, D.L., Sanocki, C.A., and Winterstein, T.A., 1994, Physical characteristics of stream subbasins in the Lac qui Parle River Basin, southwestern Minnesota and eastern South Dakota: U.S. Geological Survey Open-File Report 93-46, 12 p.

Lorenz, D.L., and Trotta, L.C., 1991, Preparation and comparison of maps showing the depth to water table, Dakota County, Minnesota: U.S. Geological Survey Open-File Report 91-245, 2 p.

Maclay, R.W., 1963, Evaluation of ground water near Stephen, Minnesota: Unpublished report on file with U.S. Geological Survey in Mounds View, Minnesota, $24 \mathrm{p}$. 
-1966, Reconnaissance of the geology and ground-water resources in the Aurora area, St. Louis County, Minnesota: U.S. Geological Survey Water-Supply Paper 1809-U, 20 p.

Maclay, R.W., Bidwell, L.E., and Winter, T.C., 1969, Water resounces of the Buffalo River watershed, west-certral Minnesota: U.S. Geological Survey Hydrologic Investigations Atlas HA-307, 3 sheets, scale 1:250,000.

Maclay, R.W., and Schiner, G.R., 1962, Aquifers in buried shore and glaciofluvial deposits along the Gladston? Beach of glacial Lake Agassiz near Stephen, Minnesota: U.S. Geological Survey Professional Paper 450-D, p. D170-D172.

Maclay, R.W., and Winter, T.C., 1967, Geochemistry and ground-water movement in northwestern Minnesota: Ground Water, v. 5, no. 1, p. 11-19.

Maclay, R.W., Winter, T.C., and Bidwell, L.E., 1968, Water resources of the Mustinka and Bois de Sioux Rivars watershed, west-central Minnesota: U.S. Geological Survey Hydrologic Investigations Atlas HA-272, 4 sheets, scale $1: 250,000$.

- 1972, Water resources of the Red River of the North drainage basin in Minnesota: U.S. Geological Survey Water-Resources Investigations Report 1-72, $129 \mathrm{p}$.

Maclay, R.W., Winter, T.C., and Pike, G.M., 1965, Water resources of the Middle River watershed, northwestern Minnesota: U.S. Geological Survey Hydrologic Investigations Atlas HA-201, 3 sheets, scale 1:250,000.

- 1967, Water resources of the Two Rivers watershed, northwestem Minnesota: U.S. Geological Survey Hydrologic Investigations Atlas HA-237, 4 sheets, scale 1:250,000.

Maderak, M.L., 1963, Quality of waters, Minnesota-A compilation, 1955-62: Minnesota Department of Conservation, Division of Waters Bulletin 21, $104 \mathrm{p}$.

1964, Relation of chemical quality of water to recharge to the Jordan Sandstone in the Minneapolis-St. Paul area, Minnesota: U.S. Geological Survey Professional Paper 501-C, p. C176-C179.

-1965, Chemical quality of ground water in the Minneapolis-St. Paul area, Minnesota: Minnesota Department of Conservation, Division of Waters Bulletin 23, $44 \mathrm{p}$.

Mann, W.B., IV, 1971, Flow characteristics of Minnesota streams: Minnesota Department of Natural Resources Technical Paper 4, $265 \mathrm{p}$.

Mann, W.B., IV, and Collier, C.R., 1970, A proposed streamflow data program for Minnesota: U.S. Geological Survey Open-File Report, 75 p.

Mann, W.B., IV, and McBride, M.S., 1972, The hydrologic balance of Lake Sallie, Becker County, Minnesota: IJ.S. Geological Survey Professional Paper 800-D, p. 189-191.

McBride, M.S., 1975, Ground water for irrigation in the Viking Basin, west-central Minnesota: U.S. Geological Survey Water-Resources Investigations Report 75-23, 48 p.

-1976, Hydrology of lakes in the Minneapolis-St. Paul metropolitan area A summary of available data: U.S. Geological Survey Water-Resources Investigations Report 76-85, 317 p.

McBride, M.S., and Pfannkuch, H.O., 1975, The distribution of seepage within lakebeds: U.S. Geological Survey Journal of Research, v. 3, no. 5, p. 505-512.

McGuinness, C.L., 1964, Generalized map showing annual runoff and productive aquifers in the conterminous United States: U.S. Geological Survey Hydrologic Investigations Atlas HA-194, 1 sheet, scale 1:5,000,000.

McIntosh, W.L., and Eister, M.F., 1972, Geologic map index of Minnesota Part B, 1953-1970: U.S. Geological Survey Minnesota Geologic Map Index, 1 sheet. 
Miller, R.T., 1981, Hydrologic data for the Pelican River Sand-Plain aquifer, western Minnesota: U.S. Geological Survey Open-File Report 80-695, 86 p.

1982, Appraisal of the Pelican River Sand-Plain aquifer, western Minnesota: U.S. Geological Survey OpenFile Report 82-347, 44 p.

1984, Determination of hydraulic conductivity in three dimensions and its relation to dispersivity in groundwater contamination by crude oil at the Bemidji, Minnesota research site, in Hult, M.F., ed., Ground-water contamination by crude oil at the Bemidji, Minnesota research site U.S. Geological Survey toxic waste ground-water contamination study: U.S. Geological Survey Water-Resources Investigations Report 84-4188, p. 49-64.

1984, Preliminary modeling of an aquifer thermal-energy storage system: U.S. Geological Survey Open-File Report 84-811, $47 \mathrm{p}$.

1985, Preliminary modeling of an aquifer thermal-energy storage system, in Subitzky, Seymour, ed., Selected papers in hydrologic sciences: U.S. Geological Survey Water-Supply Paper 2270, p. 1-19.

1986, Thermal-energy storage in a confined sandstone aquifer at St. Paul, Minnesota, in Carter, L.M.H., ed., U.S. Geological Survey Research on Energy Resources-1986: U.S. Geological Survey Circular 974, p. 41-42.

1987, Effects of local hydraulic discontinuities on the transport of crude oil residuals in ground water, Bemidji, Minnesota, in Franks, B.J., ed., U.S. Geological Survey program on toxic waste-ground-water contaminationProceedings of the third technical meeting, Pensacola, Florida, March 23-27, 1987: U.S. Geological Survey Open-File Report 87-109, p. C9.

1988, Hydrogeology and preliminary regional flow modeling at the Bemidji, Minnesota research site, in Ragone, S.E., ed., U.S. Geological Survey program on toxic waste-ground-water contamination--Proceedings of the second technical meeting Cape Cod, Massachusetts, October 21-25, 1985: U.S. Geological Survey OpenFile Report 86-481, p. C11-C16.

1989, Cyclic injection, storage, and withdrawal of heated water in a sandstone aquifer at St. Paul, MinnesotaField observations, preliminary model analysis and aquifer thermal energy efficiency: U.S. Geological Survey Open-File Report 89-261, 97 p.

Miller, R.T., and Delin, G.N., 1993, Field observations, preliminary model analysis, and aquifer thermal efficiencyCyclic injection, storage and withdrawal of heated water in a sandstone aquifer at St. Paul, Minnesota: U.S. Geological Survey Professional Paper 1530-A, 55 p.

Miller, R.T., and Voss, C.I., 1986, Finite difference grid for a doublet well in an anisotropic aquifer: Ground Water, v. 24 , no. 4 , p. $490-496$.

Miller, W.A., and Straka, G.C., 1969, Graphs of ground-water levels in Minnesota, 1962-1966: U.S. Geological Survey Open-File Report, $54 \mathrm{p}$.

Minnesota Department of Conservation, 1961, Water resources of the Minneapolis-St.Paul metropolitan area: Minnesota Department of Conservation, Division of Waters Bulletin 11, $52 \mathrm{p}$.

Mitton, G.B., 1991, Water quality data for Sauk Lake and tributaries near Sauk Center, Minnesota, 1988-89: U.S. Geological Survey Open-File Report 91-456, 57 p.

Moyle, J.B., 1956, Relationships between the chemistry of Minnesota surface waters and wildlife management: Journal of Wildlife Management, v. 20, no. 3, p. 303-320.

Myette, C.F., 1980, Hydrologic budget for Eagle Lake near Willmar, Minnesota: U.S. Geological Survey Open-File Report 80-163, 13 p. 
1982, Baseline water-quality data for sand-plain aquifers in Hubbard, Morrison, Otter Tail, and Wadena Counties, Minnesota: U.S. Geological Survey Open-File Report 82-909, 112 p.

1984, Appraisal of water from surficial-outwash aquifers in Todd County and parts of Cass and Morrison Counties, central Minnesota: U.S. Geological Survey Water-Resources Investigations Report 83-4156, 43 p.

1984, Ground-water-quality appraisal of sand-plain aquifers in Hubbard, Morrison, Otter Tail, and Wadena Counties, Minnesota: U.S. Geological Survey Water-Resources Investigations Report 84-4080, 49 p.

1985, Hydrogeology of sand-plain aquifers in Carlton, Kanabec, and Pine Counties, east-central Minnesota: U.S. Geological Survey Water-Resources Investigations Report 85-4334, 66 p.

1991, Hydrology, water quality, and simulation of ground-water flow at a taconite-tailings basin near Keewatin. Minnesota: U.S. Geological Survey Water-Resources Investigations Report 88-4230, 61 p.

Nelson, L., and Brown, R.G., 1983, Streamflow and water-quality data for wetland inflows and outflows in the "win Cities metropolitan area, Minnesota 1981-82: U.S. Geological Survey Open-File Report 83-543, 182 p.

Nordin, C.F., and Skinner, J.V., 1977, Sediment sampling for deep fast currents, in International Association for Hydraulic Research, 17th, Badan Baden, Germany, August 14-19, 1977 [Proceedings], p. 606-609.

Norvitch, R.F., 1960, Ground water in alluvial channel deposits, Nobles County. Minnesota: Minnesota Departnent of Conservation, Division of Waters Bulletin 14, 23 p.

1962, Geology of the Vermillion end moraine, Nett Lake Indian Reservation, Minnesota: U.S. Geological Survey Professional Paper 450-D, p. D130-D132.

- 1963, Reconnaissance geology and hydrology on the Nett Lake Indian Reservation, Minnesota: Unpublished report on file with U.S. Geological Survey in Mounds View, Minnesota, 35 p.

- 1964, Geology and ground-water resources of Nobles County and part of Jackson County, Minnesota: U.S. Geological Survey Water-Supply Paper 1749, 70 p.

Norvitch, R.F, Ross, T.G., and Brietkrietz, Alex, 1973, Water resources outlook for the Minneapolis-St. Pau' metropolitan area, Minnesota: U.S. Geological Survey Open-File Report 73-203, 219 p.

Norvitch, R.F., Schneider, Robert, and Godfrey, R.G., 1963, Geology and hydrology of the Elk River, Minne`nta, nuclear reactor site: U.S. Geological Survey Bulletin 1133-C, 25 p.

Norvitch, R.F., and Walton, M.S., eds.,1979, Geologic and hydrologic aspects of tunneling in the Twin Cities area, Minnesota: U.S. Geological Survey Miscellaneous Geologic Investigations Map I-1 157, 7 sheets, scale 1:24.000 and $1: 48,000$.

Novitzki, R.P., VanVoast, W.A., and Jerabek, L.A., 1969, Water resources of the Yellow Medicine River watershed, southwestern Minnesota: U.S. Geological Survey Hydrologic Investigations Atlas HA-320, 3 steets, scale $1: 250,000$.

Oakes, E.L., 1964, Bedrock topography of the eastern and central Mesabi Range, northeastern Minnesota: U.S. Geological Survey Miscellaneous Geologic Investigations Map I-389, 4 sheets.

1970, Geology and ground-water resources of the Grand Rapids area, north-central Minnesota: U.S. Geological Survey Hydrologic Investigations Atlas HA-322, 2 sheets, scale 1:48,000.

Oakes, E.L., and Bidwell, L.E., 1968, Water resources of the Mississippi headwaters watershed, north-central Minnesota: U.S. Geological Survey Hydrologic Investigations Atlas HA-278, 4 sheets, scale 1:250,000. 
Olcott, P.G., Ericson, D.W., Felsheim, P.E., and Broussard, W.L., 1978, Water resources of the Lake Superior watershed, northeastern Minnesota: U.S. Geological Survey Hydrologic Investigations Atlas HA-582, 2 sheets, scales $1: 500,000$ and $1: 1,000,000$.

Olcott, P.G., and Siegel, D.I., 1978, Physiography and surficial geology of the copper-nickel study region northeastern Minnesota: U.S. Geological Survey Open-File Report 78-51, 22 p.

Payne, G.A., 1977, Baseline water quality of Long Meadow Lake, Ponds AP-9 and AP-10 and Black Dog Creek, Hennepin and Dakota Counties, Minnesota: U.S. Geological Survey Open-File Report 77-424, 56 p.

-1979, Water-quality reconnaissance of lakes in Voyageurs National Park, Minnesota: U.S. Geological Survey Open-File Report 79-556, $40 \mathrm{p}$.

1980, Baseline water quality of Schmidt, Hornbeam, and Horseshoe Lakes, Dakota County, Minnesota: U.S. Geological Survey Water-Resources Investigations Report 80-3, 38 p.

1983, Streamflow and suspended-sediment transport in Garvin Brook, Winona County, southeastern Minnesota-Hydrologic data for 1982: U.S. Geological Survey Open-File Report 83-212, 22 p.

1989, Flow characteristics of the Clearwater River and tributaries from Clearbrook to Plummer, northwestern Minnesota: U.S. Geological Survey Water-Resources Investigations Report 89-4045, 25 p.

-1991, Sediment, nutrients, and oxygen demanding substances in the Minnesota River-Selected water-quality data, 1989-90: U.S. Geological Survey Open-File Report 91-498, 37 p.

1991, Water quality of lakes and streams in Voyageurs National Park, Minnesota, 1977-84: U.S. Geological Survey Water-Resources Investigations Report 88-4016, 95 p.

1994, Ground-water base flow to the Upper Mississippi River upstream of the Minneapolis-St. Paul area, Minnesota during July 1988, in Water Available from the Mississippi River at Minneapolis and Other Upstream Minnesota Locations During Low-Flow Conditions: U.S. Army Corps of Engineers, p. C1-C36.

1994, Sources and transport of sediment, nutrients, and oxygen-demanding substances in the Minnesota River Basin, 1989-92: U.S. Geological Survey Water-Resources Investigations Report 93-4232, 71 p.

Payne, G.A., Ayers, M.A., and Brown, R.J., 1982, Quality of runoff from small watersheds in the Twin Cities metropolitan area, Minnesota-Hydrologic data for 1980: U.S. Geological Survey Open-File Report 82-504, $289 \mathrm{p}$.

Pereira, W.E., Rostad, C.E., Garbarino, J.R., and Hult, M.F., 1983, ground-water contamination by organic bases derived from coal-tar wastes: Environmental Toxicology and Chemistry, v. 2, p. 283-294.

Pfannkuch, H.O., Nourse, S.M., and Hult, M.F., 1988, Mass transfer at the alkane water interface in laboratory columns of porous media, in Ragone, S.E., ed., U.S. Geological Survey program on toxic waste-ground-water contamination-Proceedings of the second technical meeting, Cape Cod, Massachusetts, October 21-25, 1985: U.S. Geological Survey Open-File Report 86-481, p. C29-C32.

Piatt, J.J., Eisenreich, S.J., Barkhus, D.A., and Capel, P.D., 1993, Sorption of polycyclic aromatic hydrocarbons to aquifer materials containing low-organic carbon content from Bemidji, Minnesota [abs.], in Morganwalp, D.W., and Aronson, D.A., compilers, U.S. Geological Survey Toxic Substances Hydrology Program—Abstracts of the technical meeting, Colorado Springs, Colorado, September 20-24, 1993: U.S. Geological Survey OpenFile Report 93-454, p. 129.

Prior, C.H., 1949, Magnitude and frequency of floods in Minnesota: Minnesota Department of Conservation, Division of Waters Bulletin 1, $128 \mathrm{p}$. 
Prior, C.H., and Hess, J.H., 1961, Floods in Minnesota magnitude and frequency: Minnesota Department of Conservation, Division of Waters Bulletin 12, $142 \mathrm{p}$.

Prior, C.H., Schneider, Robert, and Durum, W.H., 1953, Water resources of the Minneapolis-St. Paul area, Minnesota: U.S. Geological Survey Circular 274, 49 p.

Rainwater, F.H., 1962, Stream composition of the conterminous United States: U.S. Geological Survey Hydrologic Investigations Atlas HA-61, 3 sheets.

Reeder, H.O., 1969, Ground water for irrigation in the Perham area, Otter Tail County, west-central Minnesota: U.S. Geological Survey Open-File Report, 56 p.

1972, Availability of ground water for irrigation from glacial outwash in the Perham area, Otter Tail County, Minnesota: U.S. Geological Survey Water-Supply Paper 2003, 45 p.

1975, Ground water in the Souris-Red-Rainey region: Unpublished report on file with U.S. Geological Survey in Mounds View, Minnesota, $44 \mathrm{p}$.

-1975, Injection-pipe system for artificial recharge: U.S. Geological Survey Journal of Research, v. 3, no. 4, p. 50I-503.

1978, Summary appraisals of the Nation's ground water resources—Souris-Red-Rainey Region: U.S. Geological Survey Professional Paper 813-K, 25 p.

Reeder, H.O., and Norvitch, R.F., 1974, Hydrogeologic reconnaissance of ground-water pollution in the Pine Eend area, Dakota County, Minnesota: U.S. Geological Survey Open-File Report, 27 p.

Reeder, H.O., Wood, W.W., Ehrlich, G.G., and Sun, R.J., 1976, Artificial recharge through a well in a fissured carbonate rock. West St. Paul, Minnesota: U.S. Geological Survey Water-Supply Paper 2004, 80 p.

Revesz, Kinga, Copen, Tyler, Baedecker, M.J., and Hult, M.F, 1993, Use of carbon and hydrogen stable isotopes to investigate the production and fate of methane at a toxic waste site, Bemidji, Minnesota [abs.], in Morganwalp, D.W.. and Aronson, D.A., compilers, U.S. Geological Survey Toxic Substances Hydrology Program-Abstracts of the technical meeting, Colorado Springs, Colorado, September 20-24, 1993: U.S. Geological Survey Op?nFile Report 93-454, p. 128.

Richert, D.A., and Spieker, A.M., 1972, Real-estate lakes: U.S. Geological Survey Circular 601-G, 19 p.

Rodis, H.G., 1961, Availability of ground water in Lyon County, Minnesota: U.S. Geological Survey Circular 444, 7 p.

I961, Geology and occurrence of ground water in Lyon County, Minnesota: U.S. Geological Survey Open-File Report, 43 p.

1961, Interpretation of geologic and ground-water conditions from field data in Lyon County, Minnesota: Unpublished report on file with U.S. Geological Survey in Mounds View, Minnesota, 22 p.

1961, Use of water-well data in interpreting occurrence of aquifers in northeastern Lyon County, Minnesota: Geological Society of America Bulletin, v. 72, p. 1275-1278.

- 1963, Geology and occurrence of ground water in Lyon County, Minnesota: U.S. Geological Survey WaterSupply Paper 1619-N, 41 p.

Rodis, H.G., and Schneider, Robert, 1960, Occurrence of ground waters of low hardness and of high chloride content in Lyon County, Minnesota: U.S. Geological Survey Circular 423, 3 p.

Rogers, J.E., 1962, Reconnaissance of ground-water conditions in the Duluth municipal airport area, Minnesota: U.S. Geological Survey Open-File Report, 18 p. 
Ropes, L.H., 1969, Ground-water resources of the St. James area, south-central Minnesota: U.S. Geological Survey Hydrologic Investigations Atlas HA-334, 1 sheet, scale 1:62,5100.

Ropes, L.H., Brown, R.F., and Wheat, D.E., 1969, Reconnaissance of the Red Lake River, Minnesota: U.S. Geological Survey Hydrologic Investigations Atlas HA-299, I sheet, scale 1:250,000.

Rosenberry, D.O., Sturrock, A.M., Scarborough, J.L., and Winter, T.C., 1988, Climatic data for Williams Lake, Hubbard County, Minnesota: U.S. Geological Survey Open-File Report 88-89, 42 p.

-1988, Climatic data for Williams Lake, Hubbard County, Minnesota, 1988: U.S. Geological Survey Open-File Report 88-304, 38 p.

Rostad, C.E., Pereira, W.E., and Hult, M.F., 1985, Partitioning studies of coal-tar constituents in a two-phase contaminated ground-water system: Chemosphere, v. 14, no. 8, p. 1023-1036.

Ruhl, J.F., 1987, Hydrogeologic and water-quality characteristics of glacial-drift aquifers in Minnesota: U.S. Geological Survey Water-Resources Investigations Report 87-4224, 3 sheets.

-1987, Water-quality characteristics in glacial-drift aquifers in Minnesota [abs.]: Annual Meeting of Geological Society of America, North Central Section, 21st, St. Paul, Minnesota, April 30-May 1, 1987, Proceedings: Geological Society of America, p. 241.

1989, Flow of ground water through fractured carbonate rocks in the Prairie du Chien-Jordan aquifer, southeastern Minnesota: U.S. Geological Survey Open-File Report 89-253, 2 p.

- 1989, Water resources of the Fond du Lac Indian Reservation, east-central Minnesota: U.S. Geological Survey Water-Resources Investigations Report 88-4114, $42 \mathrm{p}$.

- 1989, Water resources of the White Earth Indian Reservation, northwestern Minnesota: U.S. Geological Survey Water-Resources Investigations Report 89-4074, 73 p.

1990, Water resources of the Red Lake Indian Reservation, northwestern Minnesota: U.S. Geological Survey Water-Resources Investigations Report 90-4163, 49 p.

- 1994, Nitrate-N concentration distribution and the presence of selected pesticides in the surficial sand aquifer of the Straight River Basin, north-central Minnesota, 1991-93 [abs.]: Midwest Ground-Water Conference, 39th, Bismarck, North Dakota, October 16-18, 1994 [Proceedings], p. 28.

1994, Quality of ground water around Vadnais Lake and in Lambert Creek watershed, and interaction of ground water with Vadnais Lake, Ramsey County, Minnesota: U.S. Geological Survey Water-Resources Investigations Report 94-4062, $59 \mathrm{p}$.

Ruhl, J.F., and Adolphson, D.G., 1986, Hydrogeologic and water-quality characteristics of the Red River, Winnipeg aquifer, northwestern Minnesota: U.S. Geological Survey Water-Resources Investigations Report 84-4111, 2 sheets.

Ruhl, J.F., and Wolf, R.J., 1983, Hydrogeologic and water-quality characteristics of the St. Peter aquifer, southeast Minnesota: U.S. Geological Survey Water-Resources Investigations Report 83-4200, 2 sheets.

1984, Hydrogeologic and water quality characteristics of the Upper Carbonate aquifer, southeastern Minnesota: U.S. Geological Survey Water-Resources Investigations Report 84-4150, 2 sheets.

Ruhl, J.F., Wolf, R.J., and Adolphson, D.G., 1982, Hydrogeologic and water-quality characteristics of the IrontonGalesville aquifer, southeast Minnesota: U.S. Geological Survey Water-Resources Investigations Report 824080,2 sheets. 
1983, Hydrogeologic and water-quality characteristics of the Prairie du Chien-Jordan aquifer, southeast Minnesota: U.S. Geological Survey Water-Resources Investigations Report 83-4045, 2 sheets.

Saboe, C.W., 1973, Flooded area of Stillwater, Minnesota: U.S. Geological Survey Open-File Report, 6 p.

Sanocki, C.A., and Krumrie, J.R., 1994, Physical characteristics of stream subbasins in the Chippewa River Basin, west-central Minnesota: U.S. Geological Survey Open-File Report 94-488, 16 p., 1 sheet, scale 1:100,000.

Schiner, G.R., 1960, Ground-water exploration and test pumping in the Halma-Lake Bronson area, Kittson County, Minnesota: U.S. Geological Survey Open-File Report, 53 p.

1963, Ground-water exploration and test pumping in the Halma-Lake Bronson area, Kittson County, Minnesota: U.S. Geological Survey Water-Supply Paper 1619-BB, 38 p.

Schiner, G.R., and Schneider, Robert, 1964, Geology and ground-water conditions of the Redwood Falls area Redwood County, Minnesota: U.S. Geological Survey Water-Supply Paper 1669-R, 46 p.

Schneider, Robert, 1958, Correlation of ground-water levels and air temperatures in the winter and spring in Minnesota: Minnesota Department of Conservation, Division of Waters Technical Paper 1, $17 \mathrm{p}$.

1962, An application of thermometry to the study of ground water: U.S. Geological Survey Water-Supply Paper 1544-B, 16 p.

Schneider, Robert, and Rodis, H.G., 1959, Aquifers in meltwater channels along the southwest flank of the DeMoines lobe, Lyon County, southwestern Minnesota [abs.]: Geological Society of America, v. 70, no. 12, p. 1671 .

1961, Aquifers in melt-water channels along the southwest flank of the Des Moines lobe, Lyon County, Minnesota: U.S. Geological Survey Water-Supply Paper 1539-F, 10 p.

Schneider, W.J., 1970, Hydrologic implications of solid-waste disposal: U.S. Geological Survey Circular 601-F, 10 p.

Schneider, W.J., Rickert, D.A., and Spieker, A.M., 1972, Role of water in urban planning and management: U.S. Geological Survey Circular 601-H, 10 p.

Schneider, W.J., and Spieker, A.M., 1969, Water for the cities-the outlook: U.S. Geological Survey Circular 601A, 6 p.

Schoenberg, M.E., 1981, Evaluation of geohydrologic data using a ground-water-flow model of the Twin Cities metropolitan area, Minnesota [abs.]: Annual Meeting, 94th, Cincinnati, Ohio, November 2-5, 1981, Proceedings: Geological Society of America, p. 548.

1981, Seasonal versus long-term potentiometric-level variations in the Mount Simon-Hinckley and Prairie du Chien-Jordan aquifers, Twin Cities metropolitan area [abs.]: Midwest Meeting of the American Geophysic 1 Union, Minneapolis, Minnesota, September 17-18, 1981, Proceedings: American Geophysical Union, p. 613.

1982, Seasonal versus long-term variations in potentiometric levels in the Mount Simon-Hinckley and Prairie du Chien-Jordan aquifers, Twin Cities metropolitan area, Minnesota [abs.]: EOS, Transactions, American Geophysical Union, v. 63, no. 33, p. 613.

1984, Water levels and water-level changes in the Prairie du Chien-Jordan and Mount Simon-Hinckley aquifers, Twin Cities metropolitan area, Minnesota, 1971-80: U.S. Geological Survey Water-Resources Investigations Report 83-4237, 23 p. 
1987, Effects of future ground-water withdrawals on water levels in the Twin Cities aquifer system, Minnesota [abs.]: Annual Meeting of the Geological Society of America, North Central Section, 21 st, St. Paul, Minnesota, April 30-May 1, 1987, Proceedings: Geological Society of America, p. 242-243.

-1987, Relation between predevelopment hydraulic heads and present-day water quality in the Twin Cities aquifer system, Minnesota [abs.], in Zaporozec, A, ed., Annual Midwest Ground Water Conference, 32nd, Madison, Wisconsin, October 28-30, 1987 [Proceedings].

1989, Factors affecting water-supply potential of the Twin Cities metropolitan area aquifer system: Journal of the Minnesota Academy of Science, v. 55, no. 1, p. 38-47.

1989, Relation of ground-water flow in bedrock aquifers and the Mississippi and Minnesota Rivers, Minneapolis and St. Paul area, Minnesota: U.S. Geological Survey Open-File Report 89-268, 2 p.

1990, Effects of present and projected ground-water withdrawals on the Twin Cities aquifer system, Minnesota: U.S. Geological Survey Water-Resources Investigations Report 90-4001, 165 p.

1994, Characterization of ground-water discharge from bedrock aquifers to the Mississippi and Minnesota Rivers at three areas, Minneapolis-St. Paul area, Minnesota: U.S. Geological Survey Water-Resources Investigations Report 94-4163, 45 p.

Schoenberg, M.E., and Guswa, J.H., 1981, Evaluating ground-water data by a flow model of the Twin Cities metropolitan area, Minnesota [abs.]: Midwest Meeting of the American Geophysical Union, Minneapolis, Minnesota, September 17-18, 1981, Proceedings: American Geophysical Union, p. 8.

1982, Evaluating ground-water data by a flow model of the Twin Cities metropolitan area, Minnesota [abs.]: EOS, Transactions, American Geophysical Union, v. 63, no. 33, p. 612.

Schoenberg, M.E., and Mitton, G.B., 1990, Monthly mean discharge at and between selected streamflow-gaging stations along the Mississippi, Minnesota and St. Croix Rivers, 1932-1987: U.S. Geological Survey Open-File Report 90-186, 36 p.

Schottler, S.P., Eisenreich, S.J., and Capel, P.D., 1990, Hydrologic and chemical controls on atrazine and alachlor in the Minnesota River [abs.]: EOS, Transactions, American Geophysical Union, v. 71, no. 43, p. 1330.

1991, Relations between water discharge and herbicide concentration in the Minnesota River, Minnesota, in Mallard, G.E., and Aronson, D.A., eds., U.S. Geological Survey Toxic Substances Hydrology ProgramProceedings of the technical meeting Monterey, California, March 11-15, 1991: U.S. Geological Survey WaterResources Investigations Report 91-4034, p. 338-342.

Schulze, P.A., and Capel, P.D., 1989, Utility and limitations of immunoassay tests as a field screening method for triazine herbicides [abs.], in Pederson, G.L., and Smith, M.M., compilers, U.S. Geological Survey Second National Symposium on Water Quality-Abstracts of the technical sessions, Orlando, Florida, November, 1217, 1989: U.S. Geological Survey Open-File Report 89-409, p. 86.

Schulze, P.A., Capel, P.D., Squillace, P.J., and Helsel, D.R., 1993, A laboratory and field evaluation of a portable immunoassay test for triazine herbicides in environmental water samples: International Journal of Environmental Analytical Chemistry, v. 53, p. 307-319.

Scott, C.H., and Skinner, J.V., 1962, Valve position indicator for P-46 sampler: Water Resources Bulletin, February, p. 9-10.

Siegel, D.I., 1979, Potential hydrologic effects of peat mining in the Red Lake peatlands, north-central MinnesotaA project plan: U.S. Geological Survey Open-File Report 79-1591, 9 p. 
1980, Dissolution kinetics of selected silicate minerals under acid conditions [abs.]: EOS, Transactions, American Geophysical Union, v. 61, p. 1152.

1981, Effect of snowmelt on the water quality of Filson Creek and Omaday Lake, northeastern Minnesota: U.S. Geological Survey Water-Resources Investigations Report 81-66, 81 p.

1981, The effect of snow melt on water quality of Filson Creek and Omaday Lake, northeastern Minnesota: Water Resources Research, v. 17, no. 1, p. 238-242.

1981, Hydrogeologic setting of the glacial Lake Agassiz peatlands, northern Minnesota: U.S. Geological Survey Water-Resources Investigations Report 81-24, $30 \mathrm{p}$.

1987, Geochemical facies and mineral dissolution, Bemidji, Minnesota research site, in Franks, B.J., ed., U.S. Geological Survey program on toxic waste ground-water contamination-Proceedings of the third technical meeting, Pensacola, Florida, March 23-27, 1987: U.S. Geological Survey Open-File Report 87-109, p. C13-C15.

1989, Geochemistry of the Cambrian-Ordovician aquifer system in the northern midwest United States: U.S. Geological Survey Professional Paper 1405-D, 76 p.

Siegel, D.I., and Erieson, D.W., 1980, Hydrology and water quality of the copper-nickel study region, northeastern Minnesota: U.S. Geological Survey Water-Resources Investigations Report 80-739, 87 p.

Siegel, D.I., Kontis, A.L., and Mandle, R.J., 1981, The chemical evolution of water quality in the CambrianOrdovician aquifer, north-central United States 1981 [abs.]: Midwest Meeting of the American Geophysical Union, Minneapolis, Minnesota, September 17-18, 1981, Proceedings: American Geophysical Union, p. 8.

-1982. The chemical evolution of water quality in the Cambrian-Ordovician aquifer, north-central United States [abs.]: EOS, Transactions, American Geophysical Union, v. 63, no. 33, p 612.

Siegel, D.I., and Mandle, R.J., 1982, Geochemical evidence for Pleistocene glacial meltwater recharge to the Cambrian-Ordovician aquifer in the north-central United States [abs.]: Geological Society of America Abstracts with Programs 1982, v. 14, no. 5, p. 288.

Siegel, D.I., and Winter, T.C., 1980, Hydrologic setting of Williams Lake, Hubbard County, Minnesota: U.S. Geological Survey Open-File Report 80-403, 56 p.

Skinner, J.V., 1960, An automatic-tracking device for visual-accumulation-tube analysis: Water Resources Bulletin, November, p. 135-137.

1968, Field test of an x-ray sediment-concentration gage: American Society of Civil Engineers, Hy. 2, no. 5\{ 68 , $3 \mathrm{p}$.

-1968, Field test results of the Model B panametrics radioisotope gage for monitoring suspended-sediment concentration in rivers and streams: Federal Inter-Agency Sedimentation Project, $37 \mathrm{p}$.

1976, Instructions for sampling with depth-integrating, suspended-sediment samplers D-74, D-74AL, D74TM, and D-74AL-TM: Federal Inter-Agency Sedimentation Project, 12 p.

1978, Instructions for the battery pack BP-76 HD: Federal Inter-Agency Sedimentation Project, 3 p.

1979, Instructions for the peristaltic pump, RP-77: Federal Inter-Agency Sedimentation Project, 5 p.

1979, Operating instructions D-77 suspended-sediment sampler: Federal Inter-Agency Sedimentation Project, $5 \mathrm{p}$.

1982, A fluid density gage for measuring suspended-sediment concentration, Part A. Gage response to steadystate and transient conditions: Federal Inter-Agency Sedimentation Project Report X, 125 p. 
-1984, Measuring the surfice area of sediment particles in measurement and analysis of sediment loads in streams: Federal Inter-Agency Sedimentation Project Report FF, 28 p.

1986, Measurement of scour depth near bridge piers: U.S. Geological Survey Water-Resources Investigations Report 85-4106, $33 \mathrm{p}$.

1986, Sampling suspended sediment in ice-covered rivers: International Northern Research Basins Symposium, 6th, Michigan Technology University, January 26-30, 1986 [Proceedings], p. 105-108.

1987, Progress report on temperature effects in vibrational type sediment-concentration gages: Federal InterAgency Sedimentation Project Report II, 48 p.

-1989, History of the Federal Inter-Agency Sedimentation Project, in Sediment Transport Modeling International Symposium, New Orleans, Louisiana, August 14-18, 1989, Proceedings: American Society of Civil Engineers, p. 266-271.

1989. Model B sediment concentration gage-Factors influencing its readings and a formula for correcting its errors in measurement and analysis of sediment load in streams: Federal Inter-Agency Sedimentation Project Report JJ, 34 p.

Skinner, J.V., and Benson, D.A., 1982, Services provided by the Federal Inter-Agency Sedimentation Project: Federal Inter-Agency Sedimentation Project, 2 p.

Skinner, J.V., and Beverage, J.P., 1970, Operators manual for proportional frequency controller: Federal InterAgency Sedimentation Project, 42 p.

1976, Instrumentation automatic collection of sediment data, in Federal Inter-Agency Sedimentation Conference, 3rd, Denver, Colorado, March 22-25, 1976, Proceedings: Federal Inter-Agency Sedimentation Project, p. 7-1-7-16.

-1981, Test and design of automatic fluvial suspended-sediment samplers: Federal Inter-Agency Sedimentation Project, 53 p.

1986, Continuous measurement of suspended-sediment concentration: Federal Inter-Agency Sedimentation Conference, 4th, Las Vegas, Nevada, March 24-27, 1986, Proceedings: Federal Inter-Agency Sedimentation Project, p. 1.29 to 1.39 .

Skinner, J.V., and Colby, V.C., 1964, Operation and maintenance of US BM-54 bed material sampler: Federal InterAgency Sedimentation Project Report M, 14 p.

Skinner, J.V., and Szalona, J.J., 1991, Gages for measuring fluvial-sediment concentration, in Ian, S.S., and Kuo, Y.H., eds., Federal Inter-Agency Sedimentation Conference, 5th, Las Vegas, Nevada, March 18-21, 1991: Proceedings: Federal Inter-Agency Sedimentation Project, p. 2. I-2.8.

Smith, C.J., Payne, G.A., and Tornes, L.H., 1990, Effects of impoundments on water quality of streams in the Coteau des Prairie_-Upper Minnesota River Basin: U.S. Geological Survey Water-Resources Investigations Report 90-4033, 67 p.

1990, Hydrologic and water-quality data for streams and impoundments in the Coteau des Prairie-Upper Minnesota River Basin: U.S. Geological Survey Open-File Report 88-84, 43 p.

Smith, S.E., 1991, Water-quality indicators in the Prairie du Chien-Jordan aquifer, southeastern Minnesota: U.S. Geological Survey Open-File Report 91-480, 2 p.

-1992. Water-quality indicators in the Prairie du Chien-Jordan aquifer, southeastern Minnesota [abs.]: Annual Midwest Ground-Water Conference, 37th, Souix Falls, South Dakota, October 14-16, 1992 [Proceedings], p. 41. 
1994. Water-quality along selected flow paths in the Prairie du Chien-Jordan aquifer, southeastern Minnesc ${ }^{\dagger}$ [abs.]: Geological Society of America Abstracts with Programs, v. 26, no. 5, p. 61-62.

Smith, S.E., and Hult, M.F., 1993, Crude-oil spill research project near Bemidji, Minnesota-A bibliography, 19841994: U.S. Geological Survey Open-File Report 93-373, 15 p.

-1993, Hydrogeologic data collected from a crude oil spill site near Bemidji, Minnesota, 1983-91: U.S. Geological Survey Open-File Report 93-496, 158 p.

Soukup, W.G.. 1980, Ground-water appraisal in northwestern Big Stone County, west-central Minnesota: U.S. Geological Survey Open-File Report 80-568, 41 p.

Soukop, W.G., Gillies, D.C., and Myette, C.F., 1984, Appraisal of the surficial aquifers in the Pomme de Terre and Chippewa River Valleys, western Minnesota: U.S. Geological Survey Water-Resources Investigations Report 84-4086, $63 \mathrm{p}$.

Stark, J.R. 1992, Stream-aquifer relations in along the Straight River, Becker and Hubbard Counties, Minnesota [abs.]: Annual Midwest Ground Water Conference, 37th, Souix Falls, South Dakota, October 14-16, 1992 [Proceedings]. p. 36.

1994. National Water-Quality Assessment Program for the Upper Mississippi River Basin: U.S. Geologica ${ }^{1}$ Survey Open-File Report 94-101, 2 p.

- 1994, Plans for a water quality assessment of the Upper Mississippi River Basin [abs.]: Annual Meeting of the Mississippi River Research Consortium, 26th, LaCrosse, Wisconsin, April 28-29, 1994 [Proceedings], p. 18.

1994, Plans for water-quality assessment of the Upper Mississippi River Basin [abs.]: Sustaining the Ecological Integrity of Large Floodplain Rivers-Application of Ecological Knowledge to River Management, LaCrosse, Wisconsin, July 12-15, 1994 [Proceedings], p. 157.

-1994, Upper Mississippi River Basin water quality assessment [abs.]: Minnesota Water '94 Managing Minnesota's Rivers and Watersheds, Minneapolis, Minnesota, April 21-22, 1994 [Proceedings], p. 16.

Stark, J.R., Armstrong, D.S., and Zwilling, D.R., 1994, Stream-aquifer interactions in the Straight River area, Becker and Hubbard Counties, Minnesota: U.S. Geological Survey Water-Resources Investigations Report S.1$4009,83 \mathrm{p}$.

Stark, J.R., and Brown, R.G., 1987, Hydrologic interactions in a wetland in Minnesota and Wisconsin [abs.]: Annual Meeting of the Geological Society of America, North Central Section, 21st, St. Paul, Minnesota, April 30-M^y 1, 1987, Proceedings: Geological Society of America, p. 247-248.

1987, Hydrology and water quality of a wetland used to receive wastewater effluent, St. Joseph, Minnesota, in National Wetland Symposium, Chicago, Illinois, September 16-18, 1987, Proceedings: Association of State Wetland Managers, Inc., p. 197-204.

Stark, J.R., Busch, J.P., and Deters, M.H., 1990, Hydrogeology and water quality of glacial-drift aquifers in the Bemidji-Bagley area, Beltrami, Clearwater, Cass, and Hubbard Counties, Minnesota: U.S. Geological Survev Water-Resources Investigations Report 89-4136, 135 p.

Stark, J.R., and Hult, M.F., 1985, Ground-water flow in the Prairie du Chien-Jordan aquifer related to contaminatinn by coal-tar derivatives, St. Louis Park, Minnesota: U.S. Geological Survey Water-Resources Investigations Report 85-4087, 57 p.

1985, Simulation of ground-water flow in the Prairie du Chien-Jordan aquifer and relation to ground-water contamination by coal-tar derivatives, St. Louis Park, Minnesota [abs.]: Annual Midwest Ground Water Conference, 30th, St. Paul, Minnesota, October 23-25, 1985 [Proceedings], p. 14. 
-1985, Simulation of ground-water flow in the Prairie du Chien-Jordan aquifer and relation to ground-water contamination by coal-tar derivatives, St. Louis Park, Minnesota: National Water Well Association Conference Exposition, Worthington, Ohio, August 19-20, 1985, Proceedings: National Water Well Association, p. 290-310.

Stark, J.R., and Payne, G.A., 1988, A comparison of hydrologic budgets of two wetlands in Minnesota and Wisconsin [abs.]: Annual Conference-Water for the Years Ahead, Quality and Quantity_ 1990 and Beyond, 24th, Milwaukee, Wisconsin, November 6-8, 1988, Proceedings: American Water Resources Association, p. 32.

Stark, J.R., Strudell, J.D., Bloomgren, P.A., and Eger, P., 1987, Ground-water and soil contamination near two pesticide-burial sites in Minnesota: U.S. Geological Survey Water-Resources Investigations Report 87-4115, $48 \mathrm{p}$.

Stark, J.R., and Zwilling, D.R., 1989, Effects of ground-water withdrawal for irrigation and quality of Straight River, north-central Minnesota [abs.]: Annual Midwest Ground Water Conference, 34th, Kalamazoo, Michigan, October 18-20, 1987, Proceedings: Western Michigan University, p. 11.

1989. Effects of ground-water withdrawals for irrigation on the quality of the Straight River, north-central Minnesota: U.S. Geological Survey Open-File Report 89-252, 2 p.

1990, Effects of ground-water withdrawal for irrigation and quality of Straight River, north-central Minnesota [abs.]: Transferring Models to Users, Denver, Colorado, November 4-9, 1990, Proceedings: American Water Resources Association, p. 1.

Stoner, J.D., 1985, Simulation of ground-water flow near a former wood-treating waste site in Fridley, MinnesotaPart II. A practical application of an analytic-element model [abs.]: Annual Midwest Ground Water Conference, 30th, St. Paul, Minnesota, October 23-25, 1985, [Proceedings], p. 18.

1991, National Water-Quality Assessment Program_-Red River of the North: U.S. Geological Survey OpenFile Report 91-151, 2 p.

Stoner, J.D., Brigham, M.E., and Cowdery, T.K., 1994, Water quality in surficial glacial-deposit aquifers in the Red River of the North drainage basin, Minnesota, North Dakota, and South Dakota [abs.]: Midwest Ground Water Conference, 39th, Bismarck, North Dakota, October 16-18, 1994 [Proceedings], p. 15.

Stoner, J.D., and Lorenz, D.L., 1992, Water quality assessment strategy for the Red River of the North Basin, North Dakota, South Dakota, and Minnesota [abs.]: North Dakota Water Quality Symposium, Bismarck, North Dakota, March 25-26, 1992, Proceedings: North Dakota State University Extension Service, p. 291.

-1994, Environmental setting of the Red River of the North Basin, Minnesota, North Dakota, and South Dakota - Framework for a regional water quality assessment [abs.], in Minnesota Water '94 Managing Minnesota's Rivers and Watersheds, Minneapolis, Minnesota, April 21-22, 1994 [Proceedings], p. 2-3.

Stoner, J.D. Lorenz, D.L., Wiche, G.J., and Goldstein, R.M., 1993, Red River of the North Basin, Minnesota, North Dakota, and South Dakota: Water Resources Research Bulletin, v. 29, no. 4, p. 575-615.

Stoner, J.D., and Schoenberg, M.E., 1989, Preliminary evaluation of effects of ground-water withdrawals on Mississippi River flow near the Twin Cities metropolitan area, Minnesota [abs.]: Water supply issues in the Metropolitan Twin Cities area-Planning for the Future Droughts and Population Growth, St. Paul, Minnesota, October 25, 1988, Proceedings: Minnesota Water Resources Research, p. 5-6.

Stoner, J.D., and Streitz, A.R., 1987, Locating confined aquifers in glacial drift with seismic reflection methods, western Minnesota [abs.]: Annual Meeting of the Geological Society of America, North Central Section, 21 st, St. Paul, Minnesota, April 30-May 1, 1987, Proceedings: Geological Society of America, p. 248.

Straka, G.C., and Miller, W.A., 1963, Graphs of ground-water levels in Minnesota, 1957-1961: Minnesota Department of Conservation, Division of Waters Bulletin 18, $58 \mathrm{p}$. 
Straka, G.C., and Schneider, Robert, 1957, Graphs of ground water levels in Minnesota through 1956: Minnesota Department Conservation, Division of Waters Bulletin 9, $42 \mathrm{p}$.

Sturrock, A.M., Rosenberry, D.O., Engelbrecht, L.G., Gothard, W.A., and Winter, T.C., 1984, Climatic date from Williams Lake, Hubbard County, Minnesota, 1983: U.S. Geological Survey Open-File Report 84-247, 41 p.

Sturrock, A.M., Rosenberry, D.O., Scarborough, J.L., and Winter, T.C., 1986, Climatic data for Williams Lal 'e, Hubbard County, Minnesota, 1984: U.S. Geological Survey Open-File Report 86-64, 62 p.

Sturrock, A.M., Rosenberry, D.O., and Winter, T.C., 1987, Climatic data for Williams Lake, Hubbard County, Minnesota, 1985: U.S. Geological Survey Open-File Report 86-607, 40 p.

Swain, E.B, Engstrom, D.R., Brigham, M.E., Henning, T.A., and Brezonik, P.L., 1992, Increasing rates of atmospheric mercury deposition in midcontinental North America: Science, v. 257, p. 784-787.

Taylor, W.W., LaBaugh, J.W., Freeberg, M.H., and Dowling, D.C., 1985, Fishery survey and related limnological conditions of Williams Lake, Hubbard County, Minnesota: U.S. Geological Survey Water-Resources Investigations Report 84-4145, 25 p.

Thomas, H.E., and Schneider, W.J., 1970, Water as an urban resource and nuisance: U.S. Geological Survey Circular 601-D, 9 p.

Thompson, G.L., 1949, Depositional patterns in sinuous melt-water channel deposits near Marshall, Lyon County, Minnesota and their hydrologic significance: Unpublished report on file with U.S. Geological Survey in Mourds View, Minnesota, $24 \mathrm{p}$.

1965. Hydrology of melt-water channels in southwestern Minnesota: U.S. Geological Survey Water-Suppl:' Paper 1809-K, 11 p.

Tornes, L.H., 1980, Preimpoundment water quality of the Wild Rice River, Norman County, Minnesota: U.S. Geological Survey Water-Resources Investigations Report 80-79, 36 p.

- 1981, Quality of surface water before implementation of a flood-control project in Chaska, Minnesota: U.S. Geological Survey Water-Resources Investigations Report 81-83, $53 \mathrm{p}$.

1985, Suspended sediment in Minnesota streams: U.S. Geological Survey Water-Resources Investigations Report 85-4312, 33 p.

1989, Effect of urban runoff on the water quality of lakes in Eagan, Minnesota: U.S. Geological Survey WaterResources Investigations Report 86-4331, 64 p.

Tornes, L.H., and Brigham, M.E., 1994, Agricultural chemicals in streams of the Red River of the North drainage basin [abs.]: Minnesota Water '94 managing Minnesota's rivers and watersheds, Minneapolis, Minnesota, April 21-22, 1994 [Proceedings], p. 3.

1994, Nutrients, suspended sediment, and pesticides in waters of the Red River of the North Basin, Minneso'a, North Dakota, and South Dakota, 1970-90: U.S. Geological Survey Water-Resources Investigations Report 93$4231,62 \mathrm{p}$.

Tornes, L.H., and Have, M.R., 1980, Water quality of four lakes in Lakeville, Minnesota: U.S. Geological Survey Water-Resources Investigations Report 80-66, 51 p.

Tornes, L.H., Puckett, L.J., Stoner, J.D., and Brigham, M.E., 1994 The effect of riparian wetlands in reducing nitrate nitrogen from a sand and gravel aquifer to a stream [abs.]: American Geophysical Union 1994 Fall Meeting, San Francisco, California, December 5-9, 1994, Proceedings: American Geophysical Union. p. 261. 
Tornes, L.H., Lorenz, D.L., Brigham, M.E., and Stoner, J.D., 1992, Plans for a water-quality assessment of the Red River of the North Basin, Minnesota, North Dakota, and South Dakota [abs.]: Minnesota Water '92Sustaining Water Resources in the '90s and Beyond, Minneapolis, Minnesota, Proceedings: University of Minnesota Water-Resources Research Center.

Trescott, P.C., Pinder, G.F., and Larson, S.P., 1976, Finite-difference model for aquifer simulation in two dimensions with results of numerical experiments: U.S. Geological Survey Techniques of Water-Resources Investigations, book 7 , chap. $\mathrm{C} 1,116 \mathrm{p}$.

Trotta, L.C., 1985, The potential for contamination of ground water based on hydrogeology-A geographic information system application [abs.]: Annual Midwest Ground Water Conference, 30th, St. Paul, Minnesota, October 23-25, 1985 [Proceedings]. p. 19.

1987, Ground-water withdrawals in Minnesota [abs.], in Zaporozec, A., ed., Annual Midwest Ground Water Conference, 32nd, Madison, Wisconsin, October 28-30, 1987 [Proceedings].

1988, Aggregation of Minnesota water-use data and transfer of data to the National water-use data system Procedures and programs: U.S. Geological Survey Open-File Report 87-40, 71 p.

1988, Inventory of interbasin water transfer in Minnesota, in Symposium on Water Use Data for Water Resources Management, Bethesda, Maryland, August 1988, Proceedings: American Water Resources Association, p. 93-105.

-1988, Inventory of interbasin water transfers in Minnesota: U.S. Geological Survey Open-File Report 88-466, $14 \mathrm{p}$.

- 1988, Sources of water-use data in Minnesota: U.S. Geological Survey Open-File Report 87-544, 2 p.

1988, Water use for aquaculture in Minnesota, 1984: U.S. Geological Survey Water-Resources Investigations Report 88-4159, $6 \mathrm{p}$.

-1990, Automation of data systems - Minnesota's approach for water-use data, in Wiltshire, D.A., ed., Selected papers in applied computer sciences 1990: U.S. Geological Survey Bulletin 1908, p. F1-F4.

1990, Minnesota water supply and use, in Carr, J.E., Chase, E.B., Paulson, R.W., and Moody, D.W., compilers, National Water Summary 1987: U.S. Geological Survey Water-Supply Paper 2350, p. 313-320.

1991, Automation of the water-use data base for Minnesota, in Balthrop, B.H., and Terry, J.E., eds., U.S. Geological Survey National Computer Technology Meeting - Proceedings, Phoenix, Arizona, November 14-18, 1988: U.S. Geological Survey Water-Resources Investigations Report 90-4162, p. 131-137.

-1991, Water use in Minnesota, 1985: State of Minnesota Department of Natural Resources Water Use Map Series, 1 sheet.

Trotta, L.C., and Horn, M.S., 1990, Importance of return flow as a component of water use: U.S. Geological Survey Open-File Report 90-I79, 2 p.

Trotta, L.C., and Lorenz, D.L.. 1993, Comparison of maps showing the depth to water table (Dakota County, Minnesota) prepared by traditional GIS methods [abs.]: Geographic Information Systems and Water Resources, Mobile, Alabama, March 14-17, 1993, Proceedings: American Water Resources Association, p. 52.

Trotta, L.C., Roddy, W.R., Rowan, M.C., and Wilson, E.J., 1992, Source and authority for national water information system II support files [abs.], in Balthrop, B.H., and Baker, E.G., eds., U.S. Geological National Computer Technology Meeting-Program and abstracts, Norfolk, Virginia, May 17-22, 1992: U.S. Geological Survey Open-File Report 92-64, p. 36. 
U.S. Geological Survey, 1951, Surface-water supplies of the Mesabi Iron Range: Minnesota Department of Conservation, Division of Waters Bulletin 5, $117 \mathrm{p}$.

1957. Supplemental chemical analysis of surface waters in the Red River of the North Basin, North Dakota and Minnesota: Unpublished report on file with U.S. Geological Survey in Mounds View, Minnesota, 40 p.

1959. Chemical analysis of surface waters, Minnesota, October 1956 to September 1958: Unpublished report on file with U.S. Geological Survey in Mounds View. Minnesota, $16 \mathrm{p}$.

- 1974, Status of projects in Minnesota, 1974-75 fiscal years: U.S. Geological Survey, 49 p.

-1975, Status of projects in Minnesota, fiscal years 1975-76: U.S. Geological Survey, 55 p.

1976, Hydrologic unit map-1974, State of Minnesota: U.S. Geological Survey, 1 sheet, scale 1:500,000.

1976, Status of projects in Minnesota, fiscal years 1976 and 1977: U.S. Geological Survey, 36 p.

1977, Status of projects in Minnesota, fiscal years 1977 and 1978: U.S. Geological Survey, 59 p.

1983, Quality assurance plan for the ground-water program of the Minnesota District: Unpublished report on file with U.S. Geological Survey in Mounds View, Minnesota, 40 p.

- 1984. Ground-water contamination by crude petroleum at the Bemidji, Minnesota research site-Compilation of resource documents and project plan March 1984, variously paged.

VanVoast, W.A., 1969, Ground water for irrigation near Lake Emily. Pope County, west-central Minnesota: U.S. Geological Survey Open-File Report, 29 p.

-1969, Profiles of regional ground-water flow in glacial deposits in Minnesota based on existing well data, in Annual Engineering Geology and Soils Engineering Symposium, 7th, Moscow, Idaho [Proceedings], p. 84-100.

1971, Ground water for irrigation in the Brooten-Belgrade area, west-central Minnesota: U.S. Geological Survey Water-Supply Paper 1899-E. 24 p.

1971, Ground water for irrigation near Lake Emily, Pope County, west-central Minnesota: U.S. Geological Survey Water-Supply Paper 1899-J, 28 p.

VanVoast, W.A., Broussard, W.L., and Wheat, D.E., 1972, Water resources of the Minnesota River-Hawk Cre $: k$ watershed, southwestern Minnesota: U.S. Geological Survey Hydrologic Investigations Atlas HA-391, 3 sheets, scale 1:250,000.

VanVoast, W.A., Jerabek, L.A., and Novitzki, R.P., 1970, Water resources of the Redwood River watershed, southwestern Minnesota: U.S. Geological Survey Hydrologic Investigations Atlas HA-345, 3 sheets.

VanVoast, W.A., and Novitzki, R.P., 1968, Ground-water flow related to streamflow and water quality: Water Resources Research, v. 4, no. 4, p. 769-775.

Wanty, R.B., Tuttle, M.L., Landon, M.K., Delin, G.N., and Bohlke, J.K., 1993, Geochemistry of nitrogen in a farmed watershed near Princeton, Minnesota [abs.], in Morganwalp, D.W., and Aronson, D.A., compilers, U.S. Geological Survey Toxic Substances Hydrology Program-Abstracts of the technical meeting, Colorado Springs, Colorado, September 20-24, 1993: U.S. Geological Survey Open-File Report 93-454, p. 93.

Warne, S.A. 1978, Map showing low-flow frequency of Minnesota streams: U.S. Geological Survey Open-File Report 78-132, 1 sheet.

Wershaw, R.L., and Fishman, M.J., 1983, Methods for the determination of organic substances in water and fluvial sediments: U.S. Geological Survey Techniques of Water-Resources Investigations, book 5, chap. A3, 173 p. 
Winter, T.C., 1971, Sequence of glaciation in the Mesabi-Vermillion Iron Range area, northeastern Minnesota: U.S. Geological Survey Professional Paper 750-C, p. C82-C88.

1972, An approach to the design of statewide or regional ground water information systems: Water Resources Research, v. 8, no. 1, p. 222-230.

-1973, Hydrogeology of glacial drift, Mesabi Iron Range, northeastern Minnesota: U.S. Geological Survey Water-Supply Paper 2029-A, 23 p.

1974, The natural quality of ground water in Minnesota: Minnesota Department of Natural Resources Bulletin $26,25 \mathrm{p}$.

1984, Reply to comment by M.P. Anderson, and J.A. Munter on, "the interaction of lakes with variably saturated porous media,": Water Resources Research, v. 20, no. 8, p. 1166.

Winter, T.C., Bidwell, L.E., and Maclay R.W., 1969, Water resources of the Otter Tail River watershed, westcentral Minnesota: U.S. Geological Survey Hydrologic Investigations Atlas HA-296, 4 sheets.

- 1970, Water resources of the Wild Rice River watershed, northwestern Minnesota: U.S. Geological Survey Hydrologic Investigations Atlas HA-339, 4 sheets, scale 1:250,000.

Winter, T.C., Cotter, R.D., and Young, H.L., 1973, Petrography and stratigraphy of glacial drift, Mesabi-Vermillion Iron Range area, northeastern Minnesota: U.S. Geological Survey Bulletin 1331-C, 41 p.

Winter, T.C., Maclay, R.W., and Pike, G.M., 1967, Water resources of the Roseau River watershed, northwestern Minnesota: U.S. Geological Survey Hydrologic Investigations Atlas HA-241, 3 sheets, scale 1:250,000.

Winter, T.C., and Norvitch, R.F., 1972, Field trip guidebook for hydrogeology of the Twin Cities Artesian Basin: Minnesota Geological Survey Guidebook 8, 35 p.

Winter, T.C., and Pfannkuch, H.O., 1976, Hydrogeology of a drift-filled bedrock valley near Lino Lakes, Anoka County, Minnesota: U.S. Geological Survey Journal of Research, v. 4, no. 3, p. 267-276.

Winter, T.C., and Wright, H.E., Jr., 1977, Paleohydrologic phenomena recorded by lake sediments: EOS, Transactions, American Geophysical Union, v. 58, no. 4, p. 188-195.

Winterstein, T.A., 1982, Annotated report and data inventory for the Mississippi and Minnesota Rivers, MinneapolisSt. Paul metropolitan area: U.S. Geological Survey Open-File Report 82-869, 99 p.

1986, Water-resources activities of the U.S. Geological Survey in the Red River Valley, Minnesota fiscal year 1986: U.S. Geological Survey, $32 \mathrm{p}$.

Winterstein, T.A., and Arntson, A.D., 1989, Cost-effectiveness of the streamflow gaging program in Minnesota: U.S. Geological Survey Water-Resources Investigations Report 88-4129, 94 p.

Winterstein, T.A., and Miller, R.A., 1994, A collaborative approach to electronic report production [abs.], in Balthrop. B.H., and Baker, E.G., compilers, U.S. Geological Survey National Computer Technology MeetingProgram and abstracts, New Orleans, Louisiana, April 10-15, 1994: U.S. Geological Survey Open-File Report 94-52, p. 59.

Winterstein, T.A., Payne, G.A., Miller, R.A., and Stark, J.R., 1993, Selected basin characteristics and waterquality data for the Minnesota River Basin: U.S. Geological Survey Open-File Report 93-164, 100 p.

Winterstein, T.A., and Stefan, H.G., 1986, Effects of nozzle orientation on sediment sampling: Federal Inter-Agency Sedimentation Conference, 4th, Las Vegas, Nevada, March 24-27, 1986, Proceedings: Federal Inter-Agency Sedimentation Project, p. 1.20-1.28. 
Wolf, R.J., 1976, Buried aquifers in the Brooten-Belgrade and Lake Emily areas, west-central Minnesota—Factors related to developing water for irrigation: U.S. Geological Survey Water-Resources Investigations Report 76$100,72 \mathrm{p}$.

1981, Hydrogeology of the Buffalo aquifer, Clay and Wilkin Counties, west-central Minnesota: U.S. Geological Survey Water-Resources Investigations Report 81-4, 83 p.

Wolf, R.J., Ruhl, J.F., and Adolphson, D.G., 1983, Hydrogeologic and water-quality characteristics of the Mo'nt Simon-Hinckley aquifer, southeast Minnesota: U.S. Geological Survey Water-Resources Investigations Re nort 83-4031, 2 sheets.

Woodward, D.G., 1982, Effects of the Mississippi River system on ground-water flow in southeastern Minneso'a [abs.]: Annual Meeting of Mississippi River Research Consortium, 15th, LaCrosse, Wisconsin, April 14-16, 1982, Proceedings: Mississippi River Research Consortium, p. 38.

1984, Areal lithologic changes in bedrock aquifers in southeastern Minnesota as determined from naturalgamma borehole logs methods, in Nielsen, D.M., and Curl, Mary, eds., Conference on Surface and Boreho'e. Geophysical Investigations, San Antonio, Texas, February 7-9, 1984, Proceedings: National Water Well Association/Environmental Protection Agency, p. 788-800.

1984, Minnesota ground-water resources, in U.S. Geological Survey National Water Summary 1984: U.S. Geological Survey Water-Supply Paper 2275, p. 261-268.

1984, The study of buried drift aquifers in Minnesota by seismic geophysical methods: U.S. Geological Survey Open-File Report, 2 p.

1985, Seismic-refraction study of suspected drift-filled bedrock valleys in Ramsey County, Minnesota: U.S. Geological Survey Water-Resources Investigations Report 85-4107, $20 \mathrm{p}$.

1985. Trends in municipal-well installations and aquifer utilization in southeastern Minnesota, 1880-1980: U.S. Geological Survey Water-Resources Investigations Report 83-4222, 99 p.

1986, Hydrogeologic framework and properties of regional aquifers in the Hollandale Embayment, southeastern Minnesota: U.S. Geological Survey Hydrologic Investigations Atlas HA-677, 2 sheets, scales $1: 1,000,000$ and $1: 2,000,000$.

Woodward, D.G., and Anderson, H.W., Jr., 1984, Hydrogeologic and water-quality characteristics of the Cretaceous aquifer, southwestern Minnesota: U.S. Geological Survey Water-Resources Investigations Report 84-4153, 2 sheets.

Woodward, D.G., and Delin, G.N., 1982, Potentiomentric surface of regional aquifers in the Hollandale Embayment, southeastern Minnesota [abs.]: EOS, Transactions, American Geophysical Union, v. 63, no. 33, p. 612 


\section{Ground Water}

Adolphson, D.G., 1983, Availability and chemical quality of water from surficial aquifers in southwest Minnesota: U.S. Geological Survey Water-Resources Investigations Report 83-4030, $37 \mathrm{p}$.

Adolphson, D.G., and Jannis, J.A., 1978, Status of projects in Minnesota, fiscal year 1978: U.S. Geological Survey, $101 \mathrm{p}$.

Adolphson, D.G., Ruhl, J.R., and Wolf, R.J., 1981, Designation of principal water-supply aquifers in Minnesota: U.S. Geological Survey Water-Resources Investigations Report 81-51, 19 p.

Aiken, G.R., Capel, P.D., Furlong, E.T., Hult, M.F., and Thorn, K.A., 1991, Mechanisms controlling the transport of organic chemicals in subsurface environments, in Mallard, G.E., and Aronson, D.A., eds., U.S. Geological Survey Toxic Substances Hydrology Program-Proceedings of the technical meeting, Monterey, California. March 11-15, 1991: U.S. Geological Survey Water-Resources Investigations Report 91-4034, p. 633-637.

Akin, P.D., 1951, Preliminary report on ground-water conditions in the Cloquet area, Carlton County, Minnesota: U.S. Geological Survey, $11 \mathrm{p}$.

Akin, P.D., and Jones, J.R., 1952, Geology and ground-water resources of the Cloquet area, Carlton County, Minnesota: Minnesota Department of Conservation, Division of Waters Bulletin 6, $63 \mathrm{p}$.

Albin, D.R., 1987, Minnesota ground-water quality: U.S. Geological Survey Open-File Report 87-733, 10 p.

1988, U.S. Geological Survey ground-water studies in Minnesota: U.S. Geological Survey Open-File Report $88-127,2 \mathrm{p}$.

Albin, D.R., and Breummen, L.B., 1987, Minnesota ground-water quality, in Moody, D.W., Carr, Jerry, Chase, E.B., and Paulson, R.W., compilers, National Water Summary 1986: U.S. Geological Survey Water-Supply Paper 2325, p. 313-320.

Alexander, E.C., Jr., Guo, Lifeng, Regan, C.P., and Landon, M.K., 1992, Geochemistry of ground water in an outwash aquifer under agricultural fields at the Management Systems Evaluation Area (MSEA) near Princeton, Minnesota [abs.]: EOS, Transactions, American Geophysical Union, v. 73, no. 43, p. 158.

Almendinger, J.E., 1991, Relation of nitrate concentrations in ground water to agricultural land use and soil type in Dakota County, Minnesota: U.S. Geological Survey Open-File Report 91-235, 2 p.

-1994, The travel-time ellipse-An approximate zone of transport: Journal of Hydrology (161), p. 365-373.

Almendinger, J.E., and Leete, Jeanette, 1994, Hydrology, geochemistry, and substrate of calcareous fens in the Minnesota River Basin [abs.]: Minnesota Water '94-Managing Minnesota's Rivers and Watersheds, Minneapolis, Minnesota, April 21-22, 1994 [Proceedings], p. 7.

Amos, G.L., 1994, Water-resources activities of the U.S. Geological Survey Minnesota District, 1993 water year: U.S. Geological Survey Open-File Report 94-338, 72 p.

Amos, G.L., and Winterstein, T.A., 1993, Water-resources activities of the U.S. Geological Survey in Minnesota, 1991: U.S. Geological Survey Open-File Report 93-65, 73 p.

Anderson, H.W., Jr., 1980, Minnesota standards for coding ground-water site inventory data: Unpublished report on file with U.S. Geological Survey in Mounds View, Minnesota, 57 p.

- 1985, Impact of agriculture on quality of water in surficial sand-plain aquifers in central Minnesota [abs.]: Annual Midwest Ground Water Conference, 30th, St. Paul, Minnesota, October 23-25, 1985 [Proceedings], p. 9.

1986, Hydrogeologic and water-quality characteristics of crystalline-rock aquifers of Archean and Proterozoic age, Minnesota: U.S. Geological Survey Water-Resources Investigations Report 86-4033, 3 sheets. 
- 1989. Effects of agriculture on quality of water in surficial sand-plain aquifers in Douglas, Kandiyohi, Pope, and Stearns Counties, Minnesota: U.S. Geological Survey Water-Resources Investigations Report 87-4040, 52 p.

1993, Effects of agricultural and residential land use on ground-water quality, Anoka Sand Plain aquifer, eastcentral Minnesota: U.S. Geological Survey Water-Resources Investigations Report 93-4074, 62 p.

Anderson, H.W., Jr., Broussard, W.L., Farrell, D.F., and Felsheim, P.E., 1976, Water resources of the Rock River watershed, southwestern Minnesota: U.S. Geological Survey Hydrologic Investigations Atlas HA-555, 3 she?ts, scale 1:250,000.

Anderson, H.W., Jr., Broussard, W.L., Farrell, D.F., and Hult, M.F., 1976, Water resources of the Des Moin 9 s River watershed, southwestern Minnesota: U.S. Geological Survey Hydrologic Investigations Atlas HA-553, 3 sheets, scales $1: 250,000$ and $1: 500,000$.

Anderson, J.L., Dowdy, R.H., and Delin, G.N., 1991, Ground water impacts from irrigated ridge tillage, in Irrigation and Drainage-1991 National Conference, Honolulu, Hawaii, July 22-26, 1991, Proceedings: American Society of Civil Engineers, Irrigation \& Drainage Division, p. 604-611.

Anderson, J.L., Dowdy, R.H., Lamb, J.A., Delin, G.N., Knighton, Ray, Clay, David, and Lowery, Birl, 1993, Northern cornbelt sand plains Management Systems Evaluation Area, in Agricultural Research to Protect Water Quality, Minneapolis, Minnesota, February 21-24, 1993, Proceedings: Soil and Water Conservation Society, p. 39-47.

Anderson, H.W., Jr., FarrelI, D.F., and Broussard, W.L., 1974, Water resources of the Blue Earth River watersl ad, south-central Minnesota: U.S. Geological Survey Hydrologic Investigations Atlas HA-525, 3 sheets, scale 1:500,000.

1974, Water resources of the lower Minnesota River watershed, south-central Minnesota: U.S. Geological Survey Hydrologic Investigations Atlas HA-526, 3 sheets, scale 1:500,000.

Anderson, H.W., Jr., Farrell, D.F., Broussard, W.L., and Felsheim, P.E., 1974, Water resources of the Cannon River watershed, southeastern Minnesota: U.S. Geological Survey Hydrologic Investigations Atlas HA-52i., 3 sheets, scales $1: 250,000$ and $1: 500,000$.

Anderson, H.W., Jr., Farrell, D.F., Broussard, W.L., and Hult, M.F., 1975, Water resources of the Zumbro River watershed, southeastern Minnesota: U.S. Geological Survey Hydrologic Investigations Atlas HA-543, 3 sheets, scale $1: 250,000$.

Anderson, H.W., Jr., and Ruhl, J.F., 1984, Geohydrology and hydrochemistry of aquifers in Cretaceous rocks Minnesota, in Geohydrology of the Dakota aquifer, C.V. Theis Conferences on Geohydrology, 1st, Lincolr. Nebraska, October 5-6, 1982, Proceedings: National Water Well Association, p. 27-37.

Anderson, H.W., Jr., and Stoner, J.D., 1989, Effects of controlled agricultural practices on water quality in a Minnesota sand-plain aquifer: U.S. Geological Survey Open-File Report 89-267, 2 p.

Baedecker, M.J., Cozzarelli, I.M., Bennett, P.C., Eganhouse, R.P., and Hult, M.F., 1993, Evolution of the contaminant plume in an aquifer contaminated with crude oil, Bemidji, Minnesota [abs.], in Morganwalp, D.W., and Aronson, D.A., compilers, U.S. Geological Survey Toxic Substances Hydrology Program-Abstracts of the technical meeting, Colorado Springs, Colorado, September 20-24, 1993: U.S. Geological Survey Open-File. Report 93-454, p. 103.

Baedecker, M.J., Eganhouse, R.P., Miller, R.T., and Hult, M.F., 1986, The composition and fate of hydrocart ons in a glacial aquifer [abs:]: Symposium on Scientific Advances in Geology and Hydrology from Studies of Contaminant Plumes, San Antonio, Texas, November 1986, Proceedings: Geological Society of America, v.18, no. 6, p. 531 . 
Baehr, A.L., and Hult, M.F., 1987, Mathematical modeling of hydrocarbon and oxygen transport coupled with microbial degradation in the unsaturated zone [abs.], in Franks, B.J., ed., U.S. Geological Survey program on toxic waste ground-water contamination - Proceedings of the third technical meeting, Pensacola, Florida, March 23-27, 1987: U.S. Geological Survey Open-File Report 87-109, p. C-27-C28.

1989, Determination of the air-phase permeability tensor of an unsaturated zone at the Bemidji, Minnesota research site, in Mallard, G.E., and Ragone, S.E., eds., U.S. Geological Survey Toxic Substances Hydrology Program-Proceedings of the technical meeting, Phoenix, Arizona, September 26-30, 1988: U.S. Geological Survey Water-Resources Investigations Report 88-4220, p. 55-62.

1991, Evaluation of unsaturated zone air permeability through pneumatic tests: Water Resources Research, v. 27 , no. 10 , p. 2605-2617.

Bennett, P.C. Siegel, D.I., Baedecker, M.J., and Hult, M.F., 1993, Crude-oil in a shallow sand and gravel aquifer-1. Hydrology and inorganic chemistry: Applied Chemistry, v. 8, no. 6, p. 529-549.

Bidwell, L.E., Winter, T.C., and Maclay, R.W., 1970, Water resources of the Red Lake River watershed, northwestern Minnesota: U.S. Geological Survey Hydrologic Investigations Atlas HA-346, 4 sheets, scales $1: 500,000$ and $1: 250,000$.

Bingham, J.W., 1960, Basic geology and ground-water data for Clay County, Minnesota: Minnesota Department of Conservation, Division of Waters Bulletin 8, $138 \mathrm{p}$.

Bohlke, J.K., Wanty, R.B., Tuttle, M.L., Delin, G.N., and Landon, M.K., 1994, Resolving the effects of varying land use and aquifer reactions on nitrate contamination of ground water in central Minnesota [abs.]: EOS, Transactions, American Geophysical Union, v. 75, no. 19, p. 154.

Broussard, W.L., Anderson, H.W., Jr., and Farrell, D.F., 1973, Water resources of the Cottonwood River watershed, southeastern Minnesota: U.S. Geological Survey Hydrologic Investigations Atlas HA-466, 3 sheets, scales, 1:253,400, 1:500,000, and 1:250,000.

Broussard, W.L., Farrell, D.F., Anderson, H.W., Jr., and Felsheim, P.E., 1975, Water resources of the Root River watershed, southeastern Minnesota: U.S. Geological Survey Hydrologic Investigations Atlas HA-548, 3 sheets, scale $1: 250,000$.

Brown, R.G., 1984, Hydrologic effects of impoundments in Sherburne National Wildlife Refuge, Minnesota: U.S. Geological Survey Water-Resources Investigations Report 84-4175, 20 p.

1986, Errors in estimating ground-water components of hydrologic and phosphorus budgets of lakes, in Subitzky, Seymour, ed., Selected papers in hydrologic sciences 1986: U.S. Geological Survey Water-Supply Paper 2310, p. 53-64.

Brown, R.F., and Cotter, R.D., 1963, Water and the Minnesota Iron Range: U.S. Geological Survey, 16 p.

Brown, R.G., Patterson, G.L., and Stark, J.R., 1986, Ground-water and surface-water interaction in wetlands-Comparisons and contrasts [abs.]: Wisconsin Section Annual Meeting, Wisconsin Dells, Wisconsin, April 3-4, 1986, Proceedings: American Water Resources Association, p. 1.

Brown, R.G., and Stark, J.R., and Patterson, G.L., 1985, Ground-water and surface-water interactions in Minnesota and Wisconsin wetlands, in Hook, D.D., McKee, W.H., Jr., Smith, H.K., Gregory, J., Burrell, V.G., Jr., DeVee M.,R., Sojka, R.E., Gilberts, S., Banks, R., Stolzy, L.H., Brooks, C., Matthews, T.D., and Shear, T.H., The ecology and management of wetlands: Portland, Oregon, Timber Press, p. 176-180.

Byers, A.C., Wenzel, L.K., Laird, W.M., and Dennis, P.E., 1946, Ground water in the Fargo-Moorhead area, North Dakota and Minnesota: U.S. Geological Survey, 72 p. 
Chang, Fu-Hsian, Hult, M.F., and Noben, N.N., 1987, Quantitative studies of biodegradation of petroleum and some model hydrocarbons in ground water and sediment environments, in Fairchild, D.M., ed., Ground-water quality and agricultural practices: Chelsea, Michigan, Lewis Publishers, p. 295-318.

Chang, Fu-Hsian, Noben, N.N., Brend, Daniel, and Hult, M.F., I988, Microbial degradation of crude oil and some model hydrocarbons, in Ragone, S.E., ed., U.S. Geological Survey program on toxic waste - ground-water contamination-Proceedings of the second technical meeting, Cape Cod, Massachusetts, October 21-25, 1985: U.S. Geological Survey Open-File Report 86-481, p. C33-C42.

Cotter, R.D., and Bidwell, L.E., 1966, Water resources of the Pomme de Terre River watershed, west-central Minnesota: U.S. Geological Survey Hydrologic Investigations Atlas HA-220, 4 sheets, scale I: 250, 000

1968, Water resources of the Lac qui Parle River watershed, southwestern Minnesota: U.S. Geological Survey Hydrologic Investigations Atlas HA-269, 4 sheets, scale 1:250,000.

Cotter, R.D., Bidwell, L.E., Oakes, E.L., and Hollenstein, G.H., 1966, Water resources of the Big Stone Lake watershed, west-central Minnesota: U.S. Geological Survey Hydrologic Investigations Atlas HA-2 I3, 4 sheets, scale $1: 250,000$.

Cotter, R.D., Bidwell, L.E., VanVoast, W.A., and Novitzki, R.P., 1968, Water resources of the Chippewa River watershed, west-central Minnesota: U.S. Geological Survey Hydrologic Investigations Atlas HA-286, 4 sheets, scale I $: 250,000$.

Cotter, R.D., and Rogers, J.E., 1961, Exploratory drilling for ground water in the Mountain Iron-Virginia area, St. Louis County, Minnesota: U.S. Geological Survey Water-Supply Paper 1539-A, I3 p.

Cotter, R.D., and Young, H.L., 1960, Municipal water supplies on the Mesabi and Vermillion Iron Ranges, northeastern Minnesota: U.S. Geological Survey, Ground Water Series Basic Data Release 1, 61 p.

Cotter, R.D., Young, H.L., Petri, R.L., and Prior, C.H., 1965, Ground and surface water in the Mesabi and Vermillion Iron Range area, northeastern Minnesota: U.S. Geological Survey Water-Supply Paper 1759-A, F. A1-A36.

1965, Water resources in the vicinity of municipalities on the central Mesabi Iron Range, northeastern Minnesota: U.S. Geological Survey Water-Supply Paper 1759-D, 20 p.

- 1965, Water resources in the vicinity of municipalities on the east-central Mesabi Iron Range, northeastern Minnesota: U.S. Geological Survey Water-Supply Paper 1759-E, 23 p.

1965, Water resources in the vicinity of municipalities on the eastern Mesabi Iron Range, northeastern Minnesota: U.S. Geological Survey Water-Supply Paper 1759-F, 27 p.

-1965, Water resources in the vicinity of municipalities on the west-central Mesabi Iron Range, northeasterr Minnesota: U.S. Geological Survey Water-Supply Paper 1759-C, 21 p.

-1965, Water resources in the vicinity of municipalities on the western Mesabi Iron Range, northeastern Minnesota: U.S. Geological Survey Water-Supply Paper 1759-B, 24 p.

Cowdery, T.K., 1994, Nutrient concentrations near the water table of the Sheyenne Delta aquifer beneath croplant areas-Preliminary results from a Red River of the North Basin land-use study [abs.], in Sorenson, S.K., ed, Proceedings Abstracts-American Water Resources Association's Symposium on the National Water-Quality Assessment (NAWQA) Program, Chicago, lllinois, November 7-9, 1994: U.S. Geological Survey Open-File Report 94-397, p. 7. 
Cowdery, T.K., and Brigham, M.E., 1992, Baseflow dissolved-solids loads to streams of the Red River of the North Basin, South Dakota, North Dakota, and Minnesota [abs.]: Annual Midwest Ground-Water Conference, 37th, Souix Falls, South Dakota, October 14-16, 1992 [Proceedings], p. 38.

Cowdery, T.K., and Goff, Karin, 1994, Nitrogen concentrations near the water table of the Sheyenne Delta aquifer beneath cropland areas, near Ransom and Richland Counties, North Dakota [abs.]: North Dakota Water-Quality Symposium, 4th biennial, Fargo, North Dakota, March 30-31, 1994, Proceedings: North Dakota State University Extension Service, p. 14.

1994, Nitrogen concentrations near the water table of the Sheyenne Delta aquifer beneath cropland areas, Ransom and Richland Counties, North Dakota, in North Dakota Water-Quality Symposium, 4th biennial, Fargo, North Dakota, March 30-31, 1994, Proceedings: North Dakota State University Extension Service, p. 89-102.

1994, Nutrient concentrations near the water table of the Sheyenne Delta aquifer beneath cropland areas, Ransom and Richland Counties, North Dakota [abs.]: Minnesota Water '94-Managing Minnesota's Rivers and Watersheds, Minneapolis, Minnesota, April 21-22, 1994 [Proceedings], p. 8-9.

Delin, G.N., 1985, Confined-drift aquifers studied near the Pomme de Terre and Chippewa Rivers, west-central Minnesota: U.S. Geological Survey Open-File Report, 2 p.

-1986, Confined-drift aquifers in Minnesota: U.S. Geological Survey Open-File Report 86-240, 2 p.

1986, Hydrogeology of confined-drift aquifers in part of west-central Minnesota [abs.]: Annual Meeting NorthCentral Section of Geological Society of America, 20th, Kent, Ohio, April 24-25, 1986, Proceedings: Geological Society of America, p. 286.

1986, Hydrogeology of confined-drift aquifers near the Pomme de Terre and Chippewa Rivers, western Minnesota: U.S. Geological Survey Open-File Report 86-4098, 90 p.

1987, Evaluation of availability of water from drift aquifers near the Pomme de Terre and Chippewa Rivers, western Minnesota: U.S. Geological Survey Water-Resources Investigations Report 86-4321, 53 p.

1987, Ground-water quality in a complex system of glacial-drift aquifers in west-central Minnesota [abs.], in Zaporozec, A., ed., Annual Midwest Ground Water Conference, 32nd, Madison, Wisconsin, October 28-30, 1987 [Proceedings].

1990, Effects of differing agricultural practices on concentrations of nitrate and atrazine in a sand-plain aquifer, western Minnesota [abs.]: EOS, Transactions, American Geophysical Union, v. 71, no. 43, p. 1329.

1990, Geohydrology and water quality of confined-drift aquifers in the Brooten-Belgrade area, west-central Minnesota: U.S. Geological Survey Water-Resources Investigations Report 88-4124, 138 p.

1990, Hydrogeology and simulation of ground-water flow in the Rochester area, southeast Minnesota, 197888: U.S. Geological Survey Water-Resources Investigations Report 90-4081, 102 p.

1990, Hydrologic considerations for delineating ground water recharge areas for wells, Rochester, Minnesota [abs.]: Minnesota water 1990-Facing Environmental Challenges of the 1990's, St. Paul, Minnesota, April 1990, Proceedings: Minnesota Water Resources Research, p. 42-43.

1991, Simulation of effects of ground-water development on water levels in glacial-drift aquifers in the Brooten-Belgrade area, west-central Minnesota: U.S. Geological Survey Water-Resources Investigations Report $88-4193,66 \mathrm{p}$.

1993, The Minnesota Management Systems Evaluation Area (MSEA) project—An overview [abs.]: Annual Water Resources Conference, 26th, St. Paul, Minnesota, October 26-27, 1993, Proceedings: American Society of Civil Engineers. 
Delin, G.N., and Almendinger, J.E., 1991, Delineation of recharge areas for selected wells in the St. Peter-Prairie du Chien-Jordan aquifer, Rochester, Minnesota: U.S. Geological Survey Open-File Report 90-397, 60 p.

1993, Delineation of recharge areas for selected wells in the St. Peter-Prairie du Chien-Jordan aquifer, Rochester, Minnesota: U.S. Geological Survey Water-Supply Paper 2397, 39 p.

Delin, G.N., Anderson, J.L., and Dowdy, R.H., 1991, Integrated hydrologic research at the northern cornbelt sardplain management system evaluation area, Minnesota, in Mallard, G.E., and Aronson, D.A., eds., U.S.

Geological Survey Toxic Substances Hydrology Program—Proceedings of the technical meeting, Monterey, California, March 11-15, 1991: U.S. Geological Survey Water-Resources Investigations Report 91-4034, p. $214-$ 218.

1992, The Minnesota Management Systems Evaluation Area Project-Assessing the effects of agricultural practices on ground-water quality [abs.]: Minnesota Water Conference, St. Paul, Minnesota, February 13-14, 1992 [Proceedings].

1992. The Minnesota Management Systems Evaluation Area Project—Assessing the effects of agricultural practices on ground-water quality [abs.]: Minnesota Water '92 - Sustaining Water Resources in the '90's and Beyond, Minneapolis, Minnesota, Proceedings: University of Minnesota Water-Resources Research Center.

Delin, G.N., and Landon, M.K., 1993, Effects of focused recharge on the transport of agricultural chemicals at the Princeton, Minnesota, Management Systems Evaluation Area, 1991-92 [abs.]: Agricultural Research to Protect Water Quality, Minneapolis, Minnesota, February 21-24, 1993, Proceedings: Soil and Water Conservation Society, p. 210-214.

1993, Effects of focused recharge on the transport of agricultural chemicals at the Princeton, Minnesota Management Systems Evaluation Area, 1991-92: U.S. Geological Survey Open-File Report 93-42, 8 p.

-1993, Effects of focused recharge on transport of agricultural chemicals at the Princeton, Minnesota Management Systems Evaluation Area, 1991-1992: U.S. Geological Survey Open-File Report 93-79, 2 p.

1993, Effects of topography on the transport of agricultural chemicals near Princeton, Minnesota, 1992 [abs ], in Morganwalp, D.W., and Aronson, D.A., compilers, U.S. Geological Survey Toxic Substances Hydrology Program-Abstracts of the technical meeting, Colorado Springs, Colorado, September 20-24, 1993: U.S. Geological Survey Open-File Report 93-454, p. 91.

Delin, G.N., and Landon, M.K., 1994, Effects of focused recharge on the transport of agricultural chemicals nea* Princeton, Minnesota, 1992 [abs.]: Minnesota Water '94_Managing Minnesota's Rivers and Watersheds, Minneapolis, Minnesota, April 21-22, 1994 [Proceedings], p. 9.

Delin, G.N., Landon, M.K., Anderson, J.L., and Dowdy, R.H., 1992, Hydrologic research at the Princeton, Minnesota Management Systems Evaluation Area: U.S. Geological Survey Open-File Report 92-107, 2 p.

1992. The Minnesota Management Systems Evaluation Area [abs.]: Agronomy Abstracts of 1992 Annual Meeting, Minneapolis, Minnesota, November 1-6, 1992, Proceedings: American Society of Agronomy, p. 32.2.

Delin, G.N., Landon, M.K., Healy, R.W., and Olsen, H.W., 1992, Preferential flow through the unsaturated zore beneath a corn field near Princeton, Minnesota [abs.]: Joint Spring Meeting of American Geophysical Union. Canadian Geophysical Union, and Mineralogical Society of America, Montreal, Canada, May 12-15, 1992, Proceedings: American Geophysical Union, p. 132.

1993, Spatial variability of unsaturated-zone properties in relation to topography in a sand-plain setting neer Princeton, Minnesota [abs.], in Morganwalp, D.W., and Aronson, D.A., compilers, U.S. Geological Survey Toxic Substance Hydrology Program-Abstracts of the technical meeting, Colorado Springs, Colorado, September 20-24, 1993: U.S. Geological Survey Open-File Report 93-454, p. 92. 
- 1994, Spatial distribution of unsaturated-zone properties in relation to topography near Princeton, Minnesota [abs.]: Minnesota Water '94 Managing Minnesota's Rivers and Watersheds, Minneapolis, Minnesota, April 21-22, 1994 [Proceedings], p. 9.

Delin, G.N., Landon, M.K., Lamb, J.A., and Anderson, J.L., 1994, Characterization of the hydrogeology and water quality at the Management Systems Evaluation Area near Princeton, Minnesota, 1991-92: U.S. Geological Survey Water-Resources Investigations Report 94-4149, $54 \mathrm{p}$.

1994, Hydrogeologic and water-quality data used to characterize the Management Systems Evaluation Area near Princeton, Minnesota, 1991: U.S. Geological Survey Open-File Report 94-337, 42 p.

Delin, G.N., and Woodward, D.G., 1984, Hydrogeologic setting and potentiometric surfaces of regional aquifers in the Hollandale Embayment, southeastern Minnesota, 1970-80: U.S. Geological Survey Water-Supply Paper 2219, p. 56.

Diedrich, M.M., and Jannis, J.A., 1980, Status of projects in Minnesota, fiscal year 1980: U.S. Geological Survey, $99 \mathrm{p}$.

1981, Status of projects in Minnesota, fiscal year 1981: U.S. Geological Survey, 58 p.

Ehrlich, G.G., Georlitz, D.F., Godsy, E.M., and Hult, M.F., 1982, Degradation of phenolic contaminants in ground water by anaerobic bacteria-St. Louis Park, Minnesota: Ground Water, v. 20, no. 6, p. 703-710.

Ericson, D.W., Lindholm, G.F., and Helgesen, J.O., 1974, Water resources of the Rum River watershed, eastcentral Minnesota: U.S. Geological Survey Hydrologic Investigations Atlas HA-509, 3 sheets, scales 1:250,000 and $1: 500,000$.

1976, Water resources of the Rainey Lake watershed, northeastern Minnesota: U.S. Geological Survey Hydrologic Investigations Atlas HA-556, 2 sheets, scale 1:1,000,000.

FarrelI, D.F., Broussard, W.L., Anderson, H.W., Jr., and Hult, M.F., 1975, Water resources of the Cedar River watershed, southeastern Minnesota: U.S. Geological Survey Hydrologic Investigations Atlas HA-552, 3 sheets, scale 1:250,000.

Feth, J.H., 1965, Preliminary map of the conterminous United States showing depth to and quality of shallowest ground water containing more than 1,000 parts per million dissolved solids: U.S. Geological Survey Hydrologic Investigations Atlas HA-199, 31 p., 2 sheets, scale 1:3,168,000.

Giacomini, E.G., Wolf, R.J., Payne, G.A., and Adolphson, D.G., 1980, Hydrologic characteristics of Elim, Skunk, and Deer Creeks, Upper Nemadji River Basin, Minnesota: U.S. Geological Survey Open-File Report 80-47, 65 p.

Guo, Lifeng, Alexander, E.C., Jr., Landon, M.K., Delin, G.N., and Regan, C.P., 1994, Geochemical characteristics and transport of agricultural leachates in a surficial sand and gravel aquifer near Princeton, Minnesota, 1991-92 [abs.]: 1993 Fall Meeting, San Francisco, California, December 6-10, 1993, Proceedings: American Geophysical Union, p. 269.

Guswa, J.H., Siegel, D.I., and Gillies, D.C., 1982, Preliminary evaluation of the ground-water-flow system in the Twin Cities metropolitan area, Minnesota: U.S. Geological Survey Water-Resources Investigations Report 82 $44,65 \mathrm{p}$.

Hatfield, J.L., Anderson, J.L., Alberts, E.E., Prato, Tony, Watts, D.G., Ward, Andrew, Delin, G.N., and Swank, Robert, 1993, Management Systems Evaluation Areas-An overview: Agricultural Research to Protect Water Quality, Minneapolis, Minnesota, February 21-24, 1993, Proceedings: Soil and Water Conservation Society, p. $1-10$.

Hein, M.D., 1982, Status of water-resources projects in Minnesota fiscal year 1982: U.S. Geological Survey, 61 p. 
Helgesen, J.O., 1971, Appraisal of ground water for irrigation in the Little Falls area, Morrison County, Minnesota: U.S. Geological Survey Open-File Report, 54 p.

1973, Appraisal of ground water for irrigation in the Little Falls area, Morrison County, Minnesota: U.S. Geological Survey Water-Supply Paper 2009-D, 40 p.

1977, Ground-water appraisal of the Pineland Sands area, central Minnesota: U.S. Geological Survey WatarResources Investigations Report 77-102, 49 p.

Helgesen, J.O., Ericson, D.W., and Lindholm, G.F., 1975, Water resources of the Mississippi and Sauk Rivers watershed, central Minnesota: U.S. Geological Survey Hydrologic Investigations Atlas HA-534, 3 sheets, scale 1:250,000.

Helgesen, J.O., and Lindholm, G.F., 1973, Geology and water-supply potential of the Anoka Sand Plain aquifer, Minnesota: U.S. Geological Survey Open-File Report, 19 p.

1977, Geology and water-supply potential of the Anoka Sand Plain aquifer, Minnesota: Minnesota Department of Natural Resources Technical Paper 6, 17 p.

Helgesen, J.O., LindhoIm, G.F., Broussard, W.L., and Ericson, D.W., 1973, Water resources of the Kettle River watershed, east-central Minnesota: U.S. Geological Survey Hydrologic Investigations Atlas HA-437, 4 sheets, scale $1: 250,000$.

Helgesen J.O., Lindholm, G.F., and Ericson, D.W., 1975, Water resources of the Lake of the Woods watershed, north-central Minnesota: U.S. Geological Survey Hydrologic Investigations Atlas HA-544, 2 sheets, scales $1: 500,000$.

1976, Water resources of the Little Rock River watershed, northeastern Minnesota: U.S. Geological Survey Hydrologic Investigations Atlas HA-551, 2 sheets, scale 1:500,000.

Herb, W.J., 1989, Minnesota District Water Resources Division—-Information and technical assistance, in Agrichemicals and ground water protection—Resources and Strategies for State and Local Management, St. Paul, Minnesota, October 24-25, 1988 [Proceedings], p. 93-97.

Hicks, J.K., 1974, Coon Rapids pool hydrographic study: U.S. Geological Survey Open-File Report, 6 p.

Horn, M.A., 1981, Data for water resources management in Minnesota, in Allee, D.J., Dworsky, L.B., and North, R.M., eds., Unified River Basin Managemen-Stage II, American Water Resources Association Symposiun, Atlanta, Georgia, October 4-8, 1981, Proceedings: American Water Resources Association, p. 429-441.

1983, Ground-water-use trends in the Twin Cities metropolitan area, Minnesota 1880-1980: U.S. Geological Survey Water-Resources Investigations Report 83-4033, 37 p.

1984, Annual ground-water use in the Twin Cities metropolitan area, Minnesota 1970-79: U.S. Geological Survey Open-File Report 84-577, 130 p.

1986, Development of a water-use data system in Minnesota: U.S. Geological Survey Water-Resources Investigations Report 85-4306, 59 p.

Hoyer, M.C., Hallgren, J.P., Uebel., M.H., Delin, G.N., Eisenreich, S.J., and Sterling, R.L., 1994, University of Minnesota Aquifer Thermal-Energy Storage (ATES) project report on the third long-term cycle: University of Minnesota, $125 \mathrm{p}$.

Hult, M.F., 1979, Design of a network for monitoring ground-water quality in Minnesota: U.S. Geological Survey Open-File Report 79-1164, 44 p. 
1984, Assessment of ground-water contamination by coal-tar derivatives, St. Louis Park area Minnesota: U.S. Geological Survey Open-File Report 84-867, 57 p.

1984. Ground-water contamination by crude oil at the Bemidji, Minnesota research site-An introduction, in Hult, M.F., ed., Ground-water contamination by crude oil at the Bemidji, Minnesota research site-U.S. Geological Survey toxic waste ground-water contamination study: U.S. Geological Survey Water-Resources Investigations Report 84-4188, p. 1-15.

1986, Transport and oxidation of hydrocarbon vapors in a shallow aquifer [abs.]: EOS. Transactions, American Geophysical Union, v. 67, no. 16, p. 279.

1987, Measurement of hydrocarbon vapors and degradation products in the unsaturated zone [abs.]: EOS, Transactions, American Geophysical Union, v. 68, no. 16, p. 327.

1987, Microbial oxidation of petroleum vapors in the unsaturated zone [abs.] in Franks, B.J., ed., U.S. Geological Survey program on toxic waste - ground-water contamination-Proceedings of the third technical meeting, Pensacola, Florida, March 23-27, 1987: U.S. Geological Survey Open-File Report 87-109 p. C25-C26.

1987, Movement and fate of crude-oil in contaminants in the subsurface environment at Bemidji, Minnesota, Chapter C, in Frank, B.J., ed., U.S. Geological Survey program on toxic waste -ground-water contaminationProceedings of the third technical meeting, Pensacola, Florida, March 23-27, 1987: U.S. Geological Survey Open-File Report 87-109, p. C3-C4.

1989. Mobilization, transport, and fate of hydrocarbon vapors in the unsaturated zone [abs.], in Mallard, G.E., and Ragone, S.E., eds., U.S. Geological Survey Toxic Substances Hydrology Program Proceedings of the technical meeting, Phoenix, Arizona, September 26-30, 1988: U.S. Geological Survey Water-Resources Investigations Report 88-4220, p. 53.

1989, Subsurface contamination at the Bemidji, Minnesota research site [abs.], in Mallard, G.E., and Ragone, S.E., eds., U.S. Geological Survey Toxic Substances Hydrology Program—Proceedings of the technical meeting, Phoenix, Arizona, September 26-30, 1988: U.S. Geological Survey Water-Resources Investigations Report 88-4220, p. 3.

1991, Overview of research on contamination of the subsurface by crude oil at the Bemidji, Minnesota toxic substances research site, in Mallard, G.E., and Aronson, D.A., eds., U.S. Geological Survey Toxic Substances Hydrology Program-Proceedings of technical meeting, Monterey, California, March 11-15, 1991: U.S. Geological Survey Water-Resources Investigations Report 91-4034, p. 611-613.

Hult, M.F., ed., 1984, Ground-water contamination by crude oil at the Bemidji, Minnesota research site-U.S. Geological Survey toxic waste-ground-water contamination study: U.S. Geological Survey Water-Resources Investigations Report 84-4188, $107 \mathrm{p}$.

Hult, M.F., Chang, F.H., and Pfannnkuch, H.O., 1986, Microbial oxidation of petroleum vapors in the unsaturated zone, in Chapman Conference on Microbial Processes in the Transport, Fate and In-situ Treatment of Subsurface Contaminants, Snowbird, Utah, October 1-3, 1986: American Geophysical Union Chapman Meeting Abstracts, p. 23-24.

Hult, M.F., and Grabbe, R.R., 1988, Distribution of gases and hydrocarbon vapors in the unsaturated zone, in Ragone, S.E., ed., U.S. Geological Survey program on toxic waste - ground water contamination-Proceedings of the second technical meeting, Cape Cod, Massachusetts, October 21-25, 1985: U.S. Geological Survey OpenFile Report 86-481, p. C21-C25. 
Hult, M.F., Landon, M.K., and Pfannkuch, H.O., 1991, Field validation of conceptual models of mobilization and transport of volatile petroleum derivatives in the unsaturated zone near Bemidji, Minnesota, in Mallard, G.E., and Aronson, D.A., eds., U.S. Geological Survey Toxic Substances Hydrology Program-Proceedings of technical meeting, Monterey, California, March 11-15, 1991: U.S. Geological Survey Water-Resources Investigations Report 91-4034, p. 621-626.

Hult, M.F., and Schoenberg, M.E., 1981, Preliminary evaluation of ground-water contamination by coal-tar derivatives, St. Louis Park area, Minnesota: U.S. Geological Survey Water-Resources Investigations Report 81$72,53 \mathrm{p}$.

1984, Preliminary evaluation of ground-water contamination by coal-tar derivatives, St. Louis Park area, Minnesota: U.S. Geological Survey Water-Supply Paper 2211, 53 p.

Jannis, J.A., 1983. Status of water-resources projects in Minnesota, fiscal year 1983: U.S. Geological Survey, 74 p. 1984, Status of projects in Minnesota, fiscal year 1984: U.S. Geological Survey Open-File Report, 84 p.

1986, Water-resources activities of the U.S. Geological Survey in Minnesota, fiscal year 1985: U.S. Geological Survey Open-File Report 86-133, 83 p.

Jannis, J.A., and Diedrich, M.M., 1979, Status of projects in Minnesota, fiscal year 1979: U.S. Geological Survey, $79 \mathrm{p}$.

Jones, J.R., Akin, P.D., and Schneider, Robert, 1963, Geology and ground-water conditions in the southern part of the Camp Ripley Military Reservation, Morrison County, Minnesota: U.S. Geological Survey Water-Supply Paper 1669-A, $32 \mathrm{p}$.

Komor, S.C., 1992, Nitrate in Minnesota sand-plain aquifers [abs.]: Joint Spring Meeting of American Geophysical Union. Canadian Geophysical Union, and Mineralogical Society of America, Montreal, Canada, May 12-15, 1992. Proceedings: American Geophysical Union, p. 125.

1993, Stable isotopes used to evaluate soil-water movements [abs.]: American Geophysical Union 1993 Spring Meeting, Baltimore, Maryland, May 24-28, 1993, Proceedings: American Geophysical Union, p. 140.

1994. Geochemistry and hydrology of a calcareous fen within the Savage Fen wetlands complex, Minnesota, USA: Geochimica et Cosmochimica Acta, v. 58, no. 16, p. 3353-3367.

1994, Geochemistry and hydrology of Savage Fen, a calcareous fen in the Minnesota River Valley [abs]: Minnesota Water '94 Managing Minnesota's Rivers and Watersheds, Minneapolis, Minnesota, April 21-22. 1994 [Proceedings], p. 9.

Komor, S.C., and Anderson, H.W., Jr., 1993, Nitrogen isotopes as indicators of nitrate sources in Minnesota sandplain aquifers: Ground Water, v. 31, no. 2, p. 260-270.

Komor, S.C., and Emerson, D.G., 1992, Atrazine and bromide movement through the unsaturated sand plains at sites in Minnesota and North Dakota [abs.]: 1992 North Dakota Water Quality Symposium, Bismarck, North Dakota, March 25-26, 1992, Proceedings: North Dakota State University Extension Service.

1994, Movements of water, solutes, and stable isotopes in the unsaturated zones of two sand plains in the Upper Midwest: Water Resources Research, v. 30, no. 2, p. 253-267.

Lamb, J.A., Anderson, J.L., Dowdy, R.H., and Delin, G.N., 1992, Northern cornbelt sandplain MSEA [abs.]: Minnesota Water '92 - Sustaining Water Resources in the '90's and Beyond, Minneapolis, Minnesota. Proceedings: University of Minnesota Water-Resources Research Center. 
Landon, M.K., and Hult, M.F. 1992, Source mass balance calculated from changes in physical properties and composition of spilled crude oil in the subsurface near Bemidji, Minnesota: EOS, Transactions, American Geophysical Union, v. 73, no. 14, p. 132-133.

Landon, M.K., Delin, G.N., Guo, Lifeng, Regan, C.P., Anderson, J.L., and Dowdy, R.H., 1992, Ground-water quality at the Management Systems Evaluation Area near Princeton, Minnesota, 1991 [abs.]: Annual Midwest Ground Water Conference, 37th, Souix Falls, South Dakota, October 14-16, 1992 [Proceedings], p. 30.

Landon, M.K., Delin, G.N., Guo, Lifeng, Regan, C.P., Lamb, J.A., Dowdy, R.H., and Anderson, J.L., 1993, Occurrence of agricultural chemicals in ground water at the Princeton, Minnesota Management Systems Evaluation Area: Agricultural Research to Protect Water Quality, Minneapolis, Minnesota, February 21-24, 1993, Proceedings: Soil and Water Conservation Society, p. 434-438.

Landon, M.K., Delin, G.N., Komor, S.C., and Regan, C.P., 1994, Stable isotopes and major anions as tracers of recharge water to a sand and gravel aquifer, central Minnesota [abs.]: EOS, Transactions, American Geophysical Union, v. 73, no. 44, p. 277.

Landon, M.K., Delin, G.N., Lamb, J.A., Anderson, J.L., and Dowdy, R.H., 1994, Impacts of farming systems on ground-water quality at the Princeton, Minnesota, Management Systems Evaluation Area (MSEA) 1991-1992 [abs.]: Minnesota Water '94-Managing Minnesota's Rivers and Watersheds, Minneapolis, Minnesota April 2122, 1994, p. 6.

Landon, M.K., Delin, G.N., Lamb, J.A., Dowdy, R.H., and Anderson, J.L., 1993, Effects of farming systems on ground water quality at the Princeton, Minnesota Management Systems Evaluation Area, 1991 [abs.], in Morganwalp, D.W., and Aronson, D.A., compilers, U.S. Geological Toxic Substances Hydrology ProgramAbstracts of the technical meeting, Colorado Springs, Colorado: U.S. Geological Survey Open-File Report 93454, p. 63.

1994, Effects of farming systems on concentrations of nitrate in ground water at the Princeton, Minnesota Management Systems Evaluation Area (MSEA), 1991-1992 [abs.]: EOS, Transactions, American Geophysical Union, v. 75, no. 19 , p. 157.

Landon, M.K., Delin, G.N., Lamb, J.A., and Guo, Lifeng, 1993, Ground-water quality at the Management Systems Evaluation Area (MSEA) near Princeton, Minnesota, 1991: U.S. Geological Survey Open-File Report 93-43, 8 p.

1993, Ground-water quality at the Management Systems Evaluation Area near Princeton, Minnesota, 1991: U.S. Geological Survey Open-File Report 93-80, 2 p.

Landon, M.K., and Hult, M.F., 1991, Evolution of physical properties and composition of a crude oil spill, in Mallard, G.E., and Aronson, D.A., eds., U.S. Geological Survey Toxic Substances Hydrology ProgramProceedings of the technical meeting, Monterey, California, March 11-15, 1991: U.S. Geological Survey WaterResources Investigations Report 91-4034, p. 641-645.

1993. Source mass balance calculated from changes on composition of spilled crude oil in the subsurface near Bemidji, Minnesota [abs.], in Morganwalp, D.W., and Aronson, D.A., compilers, U.S. Geological Survey Toxic Substances Hydrology Program—Abstracts of the technical meeting, Colorado Springs, Colorado, September 20-24, 1993: U.S. Geological Survey Open-File Report 93-454, p. 105.

Langford, R.H., 1964, Chemical quality of the water resources Kittson, Marshall, and Roseau Counties, Minnesota: Unpublished report on file with U.S. Geological Survey in Mounds View, Minnesota, 168 p.

Larson, S.P. 1976, An appraisal of ground water for irrigation in the Appleton area, west-central Minnesota: U.S. Geological Survey Water-Supply Paper 2039-B, 34 p.

Larson, S.P., McBride, M.S., and Wolf, R.J., 1975, Digital models of a glacial outwash aquifer in the Pearl-Sallie Lakes area, west-central Minnesota: U.S. Geological Survey Water-Resources Investigations Report 75-40, 39 p. 
Larson-Higdem, D.C., Larson, S.P., and Norvitch, R.F., 1975, Configuration of the water table and distribution of downward leakage to the Prairie du Chien-Jordan aquifer in the Minneapolis-St. Paul metropolitan area, Minnesota: U.S. Geological Survey Open-File Report 75-342, 33 p.

Liesch, B.A., 1961, Geohydrology of the Jordan aquifer in the Minneapolis-St. Paul area, Minnesota: Minnesota Department of Conservation, Division of Waters Technical Paper 2, $24 \mathrm{p}$.

Liesch, B.A., and Norvitch, R.F., 1963, Geology and ground-water conditions in the Chisholm-Dewey Lake area, St. Louis County, Minnesota: Unpublished report on file with U.S. Geological Survey in Mounds View, Minnesota, $68 \mathrm{p}$.

Lindgren, R.J., 1990, Simulation of ground-water flow in the Prairie du Chien-Jordan and overlying aquifers near the Mississippi River, Fridley, Minnesota: U.S. Geological Survey Water-Resources Investigations Report 90-4165, $152 \mathrm{p}$.

Lindholm, G.F., 1968, Geology and water resources of the Hibbing area, northeastern Minnesota: U.S. Geological Survey Hydrologic Investigations Atlas HA-280, 3 sheets, scale 1:24,000.

1970, An appraisal of ground water for irrigation in the Wadena area, central Minnesota: U.S. Geological Survey Water-Supply Paper 1983, 56 p.

1980, Ground-water appraisal of sand plains in Benton, Sherburne, Stearns, and Wright Counties, central Minnesota: U.S. Geological Survey Water-Resources Investigations Report 80-1285, 103 p.

Lindholm, G.F., Ericson, D.W., Broussard, W.L., and Hult, M.F., 1979, Water resources of the St. Louis River watershed, northeastern Minnesota: U.S. Geological Survey Hydrologic Investigations Atlas HA-586, 3 sheets.

Lindholm, G.F., Farrell, D.F., and Helgesen, J.O., 1974, Water resources of the Crow River watershed, southcentral Minnesota: U.S. Geological Survey Hydrologic Investigations Atlas HA-528, 3 sheets, scale 1:500,000.

Lindholm, G.F., Helgesen, J.O., Broussard, W.L., and Farrell, D.F., 1974, Water resources of the lower St. Croix River watershed, east-central Minnesota: U.S. Geological Survey Hydrologic Investigations Atlas HA-490, 3 sheets, scales $1: 250,000$ and 1:500,000.

1974, Water resources of the Snake River watershed, east-central Minnesota: U.S. Geological Survey Hydrologic Investigations Atlas HA-488, 3 sheets, scales 1:250,000 and 1:500,000.

Lindholm, G.F., Helgesen, J.O., and Ericson, D.W., 1976, Water resources of the Fork River watershed, northcentral Minnesota: U.S. Geological Survey Hydrologic Investigations Atlas HA-549, 2 sheets, scale 1:500,000.

Lindholm, G.F., and Norvitch, R.F., 1976, Ground water in Minnesota: U.S. Geological Survey Open-File Report 76-354, $100 \mathrm{p}$.

Lindholm, G.F., Oakes, E.L., Ericson, D.W., and Helgesen, J.O., 1972, Water resources of the Crow Wing River watershed, central Minnesota: U.S. Geological Survey Hydrologic Investigations Atlas HA-380, 4 sheets, scale $1: 250,000$.

Lorenz, D.L., and Stark, J.R., 1987, Evaluation of gradient-control options for contaminated ground water in the St. Peter aquifer, St. Louis Park, Minnesota [abs.]. in Zaporozec, A., ed., Annual Midwest Ground Water Conference, 32nd, Madison, Wisconsin, October 28-30, 1987 [Proceedings].

- 1990, Simulation of ground-water flow in the St. Peter aquifer in an area contaminated by coal-tar derivatives, St. Louis Park, Minnesota: U.S. Geological Survey Water-Resources Investigations Report 90-4150. 37 p.

Lorenz, D.L., and Trotta, L.C., 1991, Preparation and comparison of maps showing the depth to water table, Dakota County, Minnesota: U.S. Geological Survey Open-File Report 91-245, 2 p. 
Maclay, R.W., 1963, Evaluation of ground water near Stephen, Minnesota: Unpublished report on file with U.S. Geological Survey in Mounds View, Minnesota, $24 \mathrm{p}$.

1966, Reconnaissance of the geology and ground-water resources in the Aurora area. St. Louis County, Minnesota: U.S. Geological Survey Water-Supply Paper 1809-U, 20 p.

Maclay, R.W., Bidwell, L.E., and Winter, T.C., 1969, Water resources of the Buffalo River watershed, west-central Minnesota: U.S. Geological Survey Hydrologic Investigations Atlas HA-307, 3 sheets, scale 1:250,000.

Maclay, R.W., and Schiner, G.R., 1962, Aquifers in buried shore and glaciofluvial deposits along the Gladstone Beach of glacial Lake Agassiz near Stephen, Minnesota: U.S. Geological Survey Professional Paper 450-D, p. D170-D172.

Maclay, R.W., and Winter, T.C., 1967, Geochemistry and ground-water movement in northwestern Minnesota: Ground Water, v. 5, no. 1, p. 11-19.

Maclay, R.W., Winter, T.C., and Bidwell, L.E., 1968, Water resources of the Mustinka and Bois de Sioux Rivers watershed, west-central Minnesota: U.S. Geological Survey Hydrologic Investigations Atlas HA-272, 4 sheets, scale $1: 250,000$.

1972, Water resources of the Red River of the North drainage basin in Minnesota: U.S. Geological Survey Water-Resources Investigations Report 1-72, $129 \mathrm{p}$.

Maclay, R.W., Winter, T.C., and Pike, G.M., 1965, Water resources of the Middle River watershed, northwestern Minnesota: U.S. Geological Survey Hydrologic Investigations Atlas HA-201, 3 sheets, scale 1:250,000.

1967. Water resources of the Two Rivers watershed, northwestern Minnesota: U.S. Geological Survey Hydrologic lnvestigations Atlas HA-237, 4 sheets, 1:250,000.

Maderak, M.L., 1964, Relation of chemical quality of water to recharge to the Jordan Sandstone in the MinneapolisSt. Paul area, Minnesota: U.S. Geological Survey Professional Paper 501-C, p. C176-C179.

1965, Chemical quality of ground water in the Minneapolis-St. Paul area, Minnesota: Minnesota Department of Conservation, Division of Waters Bulletin 23, $44 \mathrm{p}$.

McBride, M.S., 1975, Ground water for irrigation in the Viking Basin, west-central Minnesota: U.S. Geological Survey Water-Resources Investigations Report 75-23, 48 p.

McBride, M.S., and Pfannkuch, H.O., 1975, The distribution of seepage within lakebeds: U.S. Geological Survey Journal of Research, v. 3, no. 5, p. 505-512.

McGuinness, C.L., 1964, Generalized map showing annual runoff and productive aquifers in the conterminous United States: U.S. Geological Survey Hydrologic Investigations Atlas HA-194, I sheet, scale 1:5,000,000.

Miller, R.T., 1981, Hydrologic data for the Pelican River Sand-Plain aquifer, western Minnesota: U.S. Geological Survey Open-File Report 80-695, 86 p.

- 1982, Appraisal of the Pelican River Sand-Plain aquifer, western Minnesota: U.S. Geological Survey OpenFile Report 82-347, 44 p.

1984. Determination of hydraulic conductivity in three dimensions and its relation to dispersivity in groundwater contamination by crude oil at the Bemidji, Minnesota research site, in Hult, M.F., ed., Ground-water contamination by crude oil at the Bemidji, Minnesota research site-U.S. Geological Survey toxic waste ground-water contamination study: U.S. Geological Survey Water-Resources Investigations Report 84-4188, p. 49-64. 
1984, Preliminary modeling of an aquifer thermal-energy storage system: U.S. Geological Survey Open-File Report 84-811. $47 \mathrm{p}$.

1985, Preliminary modeling of an aquifer thermal-energy storage system, in Subitzky, Seymour, ed., Selected papers in hydrologic sciences: U.S. Geological Survey Water-Supply Paper 2270, p. 1-19.

- 1986. Thermal-energy storage in a confined sandstone aquifer at St. Paul, Minnesota, in Carter, L.M.H., ed., U.S. Geological Survey Research on Energy Resources-1986: U.S. Geological Survey Circular 974, p. 41-42.

1987. Effects of local hydraulic discontinuities on the transport of crude oil residuals in ground water, Bemidji, Minnesota, in Franks, B.J., ed., U.S. Geological Survey program on toxic waste - ground water contamination--Proceedings of the third technical meeting. Pensacola. Florida, March 23-27, 1987: U.S. Geological Survey Open-File Report 87-109, p. C9.

1988, Hydrogeology and preliminary regional flow modeling at the Bemidji, Minnesota research site, in Ragone. S.E., ed., U.S. Geological Survey program on toxic waste-ground-water contamination-Proceedings of the second technical meeting Cape Cod, Massachusetts, October 21-25, 1985: U.S. Geological Survey OpenFile Report 86-481. p. C11-C16.

1989. Cyclic injection, storage, and withdrawal of heated water in a sandstone aquifer at St. Paul, MinnesotaField observations, preliminary model analysis and aquifer thermal energy efficiency: U.S. Geological Survey Open-File Report 89-261, 97 p.

Miller, R.T., and Delin, G.N., 1993, Field observations, preliminary model analysis, and aquifer thermal efficiency-Cyclic injection, storage and withdrawal of heated water in a sandstone aquifer at St. Paul, Minnesota: U.S. Geological Survey Professional Paper 1530-A, 55 p.

Miller, W.A., and Straka, G.C., 1969, Graphs of ground-water levels in Minnesota, 1962-1966: U.S. Geological Survey Open-File Report, 54 p.

Miller, R.T., and Voss, C.I., 1986, Finite difference grid for a doublet well in an anisotropic aquifer: Ground Water, v. 24 , no. 4 , p. $490-496$.

Minnesota Department of Conservation, 1961, Water resources of the Minneapolis-St.Paul metropolitan area: Minnesota Department of Conservation, Division of Waters Bulletin 11, $52 \mathrm{p}$.

Myette, C.F., 1982, Baseline water-quality data for sand-plain aquifers in Hubbard, Morrison, Otter Tail, and Wadena Counties, Minnesota: U.S. Geological Survey Open-File Report 82-909, 112 p.

- 1984. Appraisal of water from surficial-outwash aquifers in Todd County and parts of Cass and Morrison Counties, central Minnesota: U.S. Geological Survey Water-Resources Investigations Report 83-4156, 43 p.

1984, Ground-water-quality appraisal of sand-plain aquifers in Hubbard, Morrison, Otter Tail, and Wadena Counties, Minnesota: U.S. Geological Survey Water-Resources Investigations Report 84-4080, 49 p.

1985, Hydrogeology of sand-plain aquifers in Carlton, Kanabec, and Pine Counties, east-central Minnesota: U.S. Geological Survey Water-Resources Investigations Report 85-4334, 66 p.

1991. Hydrology, water quality, and simulation of ground-water flow at a taconite tailings basin near Keewatin, Minnesota: U.S. Geological Survey Water-Resources Investigations Report 88-4230, 61 p.

Norvitch, R.F., 1960, Ground water in alluvial channel deposits, Nobles County, Minnesota: Minnesota Department of Conservation, Division of Waters Bulletin 14,23 p.

Norvitch, R.F., 1963, Reconnaissance geology and hydrology on the Nett Lake Indian Reservation, Minnesota: Unpublished report on file with U.S. Geological Survey in Mounds View, Minnesota, 35 p. 
1964, Geology and ground-water resources of Nobles County and part of Jackson County, Minnesota: U.S. Geological Survey Water-Supply Paper 1749, 70 p.

Norvitch, R.F., Ross, T.G., and Brietkrietz, Alex, 1973, Water resources outlook for the Minneapolis-St. Paul metropolitan area, Minnesota: U.S. Geological Survey Open-File Report 73-203, 219 p.

Norvitch, R.F., Schneider, Robert, and Godfrey, R.G., 1963, Geology and hydrology of the Elk River, Minnesota, nuclear reactor site: U.S. Geological Survey Bulletin 1133-C, 25 p.

Norvitch, R.F., and Walton, M.S., eds., 1979, Geologic and hydrologic aspects of tunneling in the Twin Cities area, Minnesota: U.S. Geological Survey Miscellaneous Geologic Investigations Map I-1 157, 7 sheets, scale 1:24,000 and $1: 48,000$.

Novitzki, R.P., VanVoast, W.A., and Jerabek, L.A., 1969, Water resources of the Yellow Medicine River watershed, southwestern Minnesota: U.S. Geological Survey Hydrologic Investigations Atlas HA-320, 3 sheets, scale $1: 250,000$.

Oakes, E.L., 1970, Geology and ground-water resources of the Grand Rapids area, north-central Minnesota: U.S. Geological Survey Hydrologic Investigations Atlas HA-322, 2 sheets, scale 1:48,000.

Oakes, E.L., and Bidwell, L.E., 1968, Water resources of the Mississippi headwaters watershed, north-central Minnesota: U.S. Geological Survey Hydrologic Investigations Atlas HA-278, 4 sheets, scale 1:250,000.

Olcott, P.G., Ericson, D.W., Felsheim, P.E., and Broussard, W.L., 1978, Water resources of the Lake Superior watershed, northeastern Minnesota: U.S. Geological Survey Hydrologic Investigations Atlas HA-582, 2 sheets, scales $1: 500,000$ and $1: 1,000,000$.

Payne, G.A., 1994, Ground-water base flow to the Upper Mississippi River upstream of the Minneapolis-St. Paul area, Minnesota during July 1988, in Water Available from the Mississippi River at Minneapolis and Other Upstream Minnesota Locations During Low-Flow Conditions: U.S. Army Corps of Engineers, p. C1-C36.

Pereira, W.E., Rostad, C.E., Garbarino, J.R., and Hult, M.F., 1983, Ground-water contamination by organic bases derived from coal-tar wastes: Environmental Toxicology and Chemistry, v. 2, p. 283-294.

Piatt, J.J., Eisenreich, S.J., Barkhus, D.A., and Capel, P.D., 1993, Sorption of polycyclic aromatic hydrocarbons to aquifer materials containing low-organic carbon content from Bemidji, Minnesota [abs.], in Morganwalp, D.W., and Aronson, D.A., compilers, U.S. Geological Survey Toxic Substances Hydrology Program - Abstracts of the technical meeting, Colorado Springs, Colorado, September 20-24, 1993: U.S. Geological Survey OpenFile Report 93-454, p. 129.

Pfannkuch, H.O., Nourse, S.M., and Hult, M.F., 1988, Mass transfer at the alkane water interface in laboratory columns of porous media, in Ragone, S.E., ed., U.S. Geological Survey program on toxic waste-ground water contamination-Proceedings of the second technical meeting, Cape Cod, Massachusetts, October 21-25, 1985: U.S. Geological Survey Open-File Report 86-481, p. C29-C32.

Prior, C.H., Schneider, Robert, and Durum, W.H., 1953, Water resources of the Minneapolis-St. Paul area, Minnesota: U.S. Geological Survey Circular 274, 49 p.

Reeder, H.O., 1969, Ground water for irrigation in the Perham area, Otter Tail County, west-central Minnesota: U.S. Geological Survey Open-File Report, 56 p.

1972. Availability of ground water for irrigation from glacial outwash in the Perham area, Otter Tail County, Minnesota: U.S. Geological Survey Water-Supply Paper 2003, 45 p.

1975, Ground water in the Souris-Red-Rainey region: Unpublished report on file with U.S. Geological Survey in Mounds View, Minnesota, $44 \mathrm{p}$. 
1975, Injection-pipe system for artificial recharge: U.S. Geological Survey Journal of Research, v. 3, no. 4, p. $501-503$.

-1978, Summary appraisals of the Nation's ground-water resources—Souris-Red-Rainey Region: U.S. Geological Survey Professional Paper 813-K, 25 p.

Reeder, H.O., and Norvitch, R.F., 1974, Hydrogeologic reconnaissance of ground-water pollution in the Pine Bend area, Dakota County, Minnesota: U.S. Geological Survey Open-File Report, 27 p.

Reeder, H.O., Wood, W.W., Ehrlich, G.G., and Sun, R.J., 1976, Artificial recharge through a well in a fissured carbonate rock, West St. Paul, Minnesota: U.S. Geological Survey Water-Supply Paper 2004, 80 p.

Revesz, Kinga, Copen, Tyler, Baedecker, M.J., and Hult, M.F., 1993, Use of carbon and hydrogen stable isotopes to investigate the production and fate of methane at a toxic waste site, Bemidji, Minnesota [abs.], in Morganwalp, D.W., and Aronson, D.A., compilers, U.S. Geological Survey Toxic Substances Hydrology Program-Abstracts of the technical meeting, Colorado Springs, Colorado, September 20-24, 1993: U.S. Geological Survey OpenFile Report 93-454, p. 128.

Rodis, H.G., 1961, Availability of ground water in Lyon County, Minnesota: U.S. Geological Survey Circular 444, 7 p.

-196I, Geology and occurrence of ground water in Lyon County, Minnesota: U.S. Geological Survey Open-File Report, 43 p.

- 1961, Interpretation of geologic and ground-water conditions from field data in Lyon County, Minnesota: Unpublished report on file with U.S. Geological Survey in Mounds View, Minnesota, 22 p.

1961, Use of water-well data in interpreting occurrence of aquifers in northeastern Lyon County, Minnesota: Geological Society of America Bulletin, v. 72, p. 1275-1278.

1963, Geology and occurrence of ground water in Lyon County, Minnesota: U.S. Geological Survey WaterSupply Paper 1619-N, 41 p.

Rodis, H.G., and Schneider, Robert, 1960, Occurrence of ground waters of low hardness and of high chloride content in Lyon County, Minnesota: U.S. Geological Survey Circular 423, 3 p.

Rogers, J.E., 1962, Reconnaissance of ground-water conditions in the Duluth municipal airport area, Minnesota: U.S. Geological Survey Open-File Report, 18 p.

Ropes, L.H., 1969, Ground-water resources of the St. James area, south-central Minnesota: U.S. Geological Survey Hydrologic Investigations Atlas HA-334, 1 sheet, scale 1:62,500.

Rostad, C.E., Pereira, W.E., and Hult, M.F., 1985, Partitioning studies of coal-tar constituents in a two-phase contaminated ground-water system: Chemosphere, v. 14, no. 8, p. 1023-1036.

Ruhl, J.F., 1987, Hydrogeologic and water-quality characteristics of glacial-drift aquifers in Minnesota: U.S. Geological Survey Water-Resources Investigations Report 87-4224, 3 sheets.

1987, Water-quality characteristics in glacial-drift aquifers in Minnesota [abs.]: Annual Meeting of the Geological Society of America, North Central Section, 21 st, St. Paul, Minnesota, April 30-May 1, 1987, Proceedings: Geological Society of America, p. 241.

-1989, Flow of ground water through fractured carbonate rocks in the Prairie du Chien-Jordan aquifer, southeastern Minnesota: U.S. Geological Survey Open-File Report 89-253, 2 p.

-1989, Water resources of the Fond du Lac Indian Reservation, east-central Minnesota: U.S. Geological Survey Water-Resources Investigations Report 88-4114, 42 p. 
1989, Water resources of the White Earth Indian Reservation, northwestern Minnesota: U.S. Geological Survey Water-Resources Investigations Report 89-4074, 73 p.

- 1990, Water resources of the Red Lake Indian Reservation, northwestern Minnesota: U.S. Geological Survey Water-Resources Investigations Report 90-4163, $49 \mathrm{p}$.

1994, Nitrate- $\mathrm{N}$ concentration distribution and the presence of selected pesticides in the surficial sand aquifer of the Straight River Basin, north-central Minnesota, 1991-93 [abs.]: Midwest Ground-Water Conference, 39th. Bismarck, North Dakota, October 16-18, 1994 [Proceedings], p. 28.

1994, Quality of ground water around Vadnais Lake and in Lambert Creek watershed, and interaction of ground water with Vadnais Lake, Ramsey County, Minnesota: U.S. Geological Survey Water-Resources Investigations Report 94-4062, $59 \mathrm{p}$.

Ruhl, J.F., and Adolphson, D.G., 1986, Hydrogeologic and water-quality characteristics of the Red River, Winnipeg aquifer, northwestern Minnesota: U.S. Geological Survey Water-Resources Investigations Report 84-4111, 2 sheets.

Ruhl, J.F., and Wolf, R.J., 1983, Hydrogeologic and water-quality characteristics of the St. Peter aquifer, southeast Minnesota: U.S. Geological Survey Water-Resources Investigations Report 83-4200, 2 sheets.

1984, Hydrogeologic and water quality characteristics of the Upper Carbonate aquifer, southeastern Minnesota: U.S. Geological Survey Water-Resources Investigations Report 84-4150, 2 sheets.

Ruhl, J.F., Wolf, R.J., and Adolphson, D.G., 1982, Hydrogeologic and water-quality characteristics of the IrontonGalesville aquifer, southeast Minnesota: U.S. Geological Survey Water-Resources Investigations Report 82 4080, 2 sheets.

1983, Hydrogeologic and water-quality characteristics of the Prairie du Chien-Jordan aquifer, southeast Minnesota: U.S. Geological Survey Water-Resources Investigations Report 83-4045, 2 sheets.

Schiner, G.R., 1960, Ground-water exploration and test pumping in the Halma-Lake Bronson area, Kittson County, Minnesota: U.S. Geological Survey Open-File Report, 53 p.

1963, Ground-water exploration and test pumping in the Halma-Lake Bronson area, Kittson County, Minnesota: U.S. Geological Survey Water-Supply Paper 1619-BB, 38 p.

Schiner, G.R., and Schneider, Robert, 1964, Geology and ground-water conditions of the Redwood Falls area Redwood County, Minnesota: U.S. Geological Survey Water-Supply Paper 1669-R, 46 p.

Schneider, Robert, 1958, Correlation of ground-water levels and air temperatures in the winter and spring in Minnesota: Minnesota Department of Conservation, Division of Waters Technical Paper 1, $17 \mathrm{p}$.

1962, An application of thermometry to the study of ground water: U.S. Geological Survey Water-Supply Paper 1544-B, $16 \mathrm{p}$.

Schneider, Robert, and Rodis, H.G., 1959, Aquifers in meltwater channels along the southwest flank of the Des Moines lobe, Lyon County, southwestern Minnesota [abs.]: Geological Society of America, v. 70, no. 12, p. 1671.

1961. Aquifers in melt-water channels along the southwest flank of the Des Moines lobe, Lyon County, Minnesota: U.S. Geological Survey Water-Supply Paper 1539-F, 10 p.

Schneider, W.J., 1970, Hydrologic implications of solid-waste disposal: U.S. Geological Survey Circular 601-F, $10 \mathrm{p}$. 
Schneider, W.J., Rickert, D.A., and Spieker, A.M., 1972, Role of water in urban planning and management: U.S. Geological Survey Circular 601-H, $10 \mathrm{p}$.

Schneider, W.J., and Spieker, A.M., 1969, Water for the cities- the outlook: U.S. Geological Survey Circular 601A, 6 p.

Schoenberg, M.E.. 1981, Evaluation of geohydrologic data using a ground-water-flow model of the Twin Cities metropolitan area, Minnesota 1981 [abs.]: Annual Meeting, 94th, Cincinnati, Ohio, November 2-5, 1981. Proceedings: Geological Society of America p. 548.

1981. Seasonal versus long-term potentiometric-level variations in the Mount Simon-Hinckley and Prairie du Chien-Jordan aquifers, Twin Cities metropolitan area [abs.]: Midwest Meeting of the American Geophysical Union, Minneapolis, Minnesota, September 17-18, 1981, Proceedings: American Geophysical Union, p. 613.

1982, Seasonal versus long-term variations in potentiometric levels in the Mount Simon-Hinckley and Prairie du Chien-Jordan aquifers, Twin Cities metropolitan area, Minnesota [abs.]: EOS, Transactions, American Geophysical Union, v. 63, no. 33, p. 613.

1984, Water levels and water-level changes in the Prairie du Chien-Jordan and Mount Simon-Hinckley aquifers, Twin Cities metropolitan area, Minnesota, 1971-80: U.S. Geological Survey Water-Resources Investigations Report 83-4237, $23 \mathrm{p}$.

1987, Effects of future ground-water withdrawals on water levels in the Twin Cities aquifer system, Minnesota [abs.]: Annual Meeting of the Geological Society of America, North Central Section, 21 st, St. Paul, Minnesota, April 30-May 1, 1987, Proceedings: Geological Society of America, p. 242-243.

1987, Relation between predevelopment hydraulic heads and present-day water quality in the Twin Cities aquifer system, Minnesota [abs.], in Zaporozec, A. ed., Annual Midwest Ground Water Conference, 32nd, Madison, Wisconsin, October 28-30, 1987 [Proceedings].

1989, Factors affecting water-supply potential of the Twin Cities metropolitan area aquifer system: Journal of the Minnesota Academy of Science, v. 55, no. 1, p. 38-47.

1989, Relation of ground-water flow in bedrock aquifers and the Mississippi and Minnesota Rivers, Minneapolis and St. Paul area, Minnesota: U.S. Geological Survey Open-File Report 89-268, 2 p.

1990. Effects of present and projected ground-water withdrawals on the Twin Cities aquifer system, Minnesota: U.S. Geological Survey Water-Resources Investigations Report 90-4001, 165 p.

1994, Characterization of ground-water discharge from bedrock aquifers to the Mississippi and Minnesota Rivers at three areas, Minneapolis-St. Paul area, Minnesota: U.S. Geological Survey Water-Resources Investigations Report 94-4163, 45 p.

Schoenberg, M.E., and Guswa, J.H., 1981, Evaluating ground-water data by a flow model of the Twin Cities metropolitan area, Minnesota [abs.]: Midwest Meeting of the American Geophysical Union, Minneapolis, Minnesota, September 17-18, 1981, Proceedings: American Geophysical Union, p. 8.

1982. Evaluating ground-water data by a flow model of the Twin Cities metropolitan area, Minnesota [abs.]: EOS, Transactions, American Geophysical Union, v. 63, no. 33, p. 612.

Schulze, P.A., and Capel, P.D., 1989, Utility and limitations of immunoassay tests as a field screening method for triazine herbicides [abs.], in Pederson, G.L., and Smith, M.M., compilers, U.S. Geological Survey Second National Symposium on Water Quality-Abstracts of the technical sessions, Orlando, Florida, November, 1217, 1989: U.S. Geological Survey Open-File Report 89-409, p. 86. 
Siegel, D.I., 1979, Potential hydrologic effects of peat mining in the Red Lake peatlands, north-central MinnesotaA project plan: U.S. Geological Survey Open-File Report 79-1591, 9 p.

- 1981, Hydrogeologic setting of the glacial Lake Agassiz peatlands, northern Minnesota: U.S. Geological Survey Water-Resources Investigations Report 81-24, $30 \mathrm{p}$.

1989, Geochemistry of the Cambrian-Ordovician aquifer system in the northern midwest United States: U.S. Geological Survey Professional Paper 1405-D, 76 p.

Siegel, D.I., and Ericson, D.W., 1980, Hydrology and water quality of the copper-nickel study region, northeastern Minnesota: U.S. Geological Survey Water-Resources Investigations Report 80-739, 87 p.

Siegel, D.I., Kontis, A.L., and Mandle, R.J., 1981, The chemical evolution of water quality in the CambrianOrdovician aquifer, north-central United States 1981 [abs.]: Midwest Meeting of the American Geophysical Union, Minneapolis, Minnesota, September 17-18, 1981, Proceedings: American Geophysical Union, p. 8.

1982, The chemical evolution of water quality in the Cambrian-Ordovician aquifer, north-central United States [abs.]: EOS, Transactions, American Geophysical Union, v. 63, no. 33, p. 612.

Siegel, D.I., and Mandle, R.J., 1982, Geochemical evidence for Pleistocene glacial meltwater recharge to the Cambrian-Ordovician aquifer in the north-central United States [abs.]: Geological Society of America Abstracts with Programs 1982, v. 14, no. 5, p. 288.

Siegel, D.I., and Winter, T.C., 1980, Hydrologic setting of Williams Lake, Hubbard County, Minnesota: U.S. Geological Survey Open-File Report 80-403, 56 p.

Smith, S.E., 1991, Water-quality indicators in the Prairie du Chien-Jordan aquifer, southeastern Minnesota: U.S. Geological Survey Open-File Report 91-480, 2 p.

1992, Water-quality indicators in the Prairie du Chien-Jordan aquifer, southeastern Minnesota [abs.]: Annual Midwest Ground-Water Conference. 37th, Souix Falls, South Dakota, October 14-16, 1992 [Proceedings], p. 41.

-1994, Water-quality along selected flow paths in the Prairie du Chien-Jordan aquifer, southeastern Minnesota [abs.]: Geological Society of America Abstracts with Programs, v. 26, no. 5, p. 61-62.

Smith, S.E., and Hult, M.F., 1993, Crude-oil spill research project near Bemidji, Minnesota-A bibliography, 19841994: U.S. Geological Survey Open-File Report 93-373, 15 p.

-1993, Hydrogeologic data collected from a crude oil spill site near Bemidji, Minnesota, 1983-91: U.S. Geological Survey Open-File Report 93-496, 158 p.

Soukup, W.G., 1980, Ground-water appraisal in northwestern Big Stone County, west-central Minnesota: U.S. Geological Survey Open-File Report 80-568, 41 p.

Soukup, W.G., Gillies, D.C., and Myette, C.F., 1984, Appraisal of the surficial aquifers in the Pomme de Terre and Chippewa River Valleys, western Minnesota: U.S. Geological Survey Water-Resources lnvestigations Report 84-4086, 63 p.

Stark, J.R., 1992, Stream-aquifer relations along the Straight River, Becker and Hubbard Counties, Minnesota [abs.]: Annual Midwest Ground Water Conference, 37th, Souix Falls, South Dakota, October 14-16, 1992 [Proceedings], p. 36.

1994. National Water-Quality Assessment Program for the Upper Mississippi River Basin: U.S. Geological Survey Open-File Report 94-101, 2 p.

1994, Plans for a water quality assessment of the Upper Mississippi River Basin [abs.]: Annual Meeting of the Mississippi River Research Consortium, 26th, LaCrosse, Wisconsin, April 28-29, 1994 [Proceedings], p. 18. 
1994, Plans for water-quality assessment of the Upper Mississippi River Basin [abs.]: Sustaining the Ecological Integrity of Large Floodplain Rivers - Application of Ecological Knowledge to River Management, LaCrosse, Wisconsin, July 12-15, 1994 [Proceedings], p. 157.

1994, Upper Mississippi River Basin water quality assessment [abs.]: Minnesota Water '94-Managing Minnesota's Rivers and Watersheds, Minneapolis, Minnesota, April 21-22, 1994 [Proceedings], p. 16.

Stark, J.R., Armstrong, D.S., and Zwilling, D.R., 1994, Stream-aquifer interactions in the Straight River area, Becker and Hubbard Counties, Minnesota: U.S. Geological Survey Water-Resources Investigations Report 944009 , p. 83.

Stark, J.R., and Brown, R.G., 1987, Hydrologic interactions in a wetland in Minnesota and Wisconsin [abs.]: Annual Meeting of the Geological Society of America, North Central Section, 21st, St. Paul, Minnesota, April 30-May 1, 1987, Proceedings: Geological Society of America, p. 247-248.

1987, Hydrology and water quality of a wetland used to receive wastewater effluent, St. Joseph, Minnesota, in National Wetland Symposium, Chicago, Illinois, September 16-18, 1987, Proceedings: Association of State Wetland Managers, Inc., p. 197-204.

Stark, J.R., Busch, J.P., and Deters, M.H., 1990, Hydrogeology and water quality of glacial-drift aquifers in the Bemidji-Bagley area, Beltrami, Clearwater, Cass, and Hubbard Counties, Minnesota: U.S. Geological Survey Water-Resources Investigations Report 89-4136, 135 p.

Stark, J.R., and Hult, M.F., 1985, Ground-water flow in the Prairie du Chien-Jordan aquifer related to contamination by coal-tar derivatives, St. Louis Park, Minnesota: U.S. Geological Survey Water-Resources Investigations Report 85-4087, 57 p.

1985, Simulation of ground-water flow in the Prairie du Chien-Jordan aquifer and relation to ground-water contamination by coal-tar derivatives, St. Louis Park, Minnesota [abs.]: Annual Midwest Ground Water Conference, 30th, St. Paul, Minnesota, October 23-25, 1985 [Proceedings], p. 14.

- 1985, Simulation of ground-water flow in the Prairie du Chien-Jordan aquifer and relation to ground-water contamination by coal-tar derivatives, St. Louis Park, Minnesota: National Water Well Association Conference Exposition, Worthington, Ohio, August 19-20, 1985, Proceedings: National Water Well Association, p. 290-310.

Stark, J.R., and Payne, G.A., 1988, A comparison of hydrologic budgets of two wetlands in Minnesota and Wisconsin [abs.]: Annual Conference-Water for the Years Ahead, Quality and Quantity-1990 and Beyond, 24th, Milwaukee, Wisconsin, November 6-8, 1988, Proceedings: American Water Resources Association, p. 32.

Stark, J.R., Strudell, J.D., Bloomgren, P.A., and Eger, Paul, 1987, Ground-water and soil contamination near two pesticide-burial sites in Minnesota: U.S. Geological Survey Water-Resources Investigations Report 87-4115, 48 p.

Stark, J.R., and Zwilling, D.R., 1989, Effects of ground-water withdrawal for irrigation and quality of Straight River, north-central Minnesota [abs.]: Annual Midwest Ground Water Conference, 34th, Kalamazoo, Michigan, October 18-20, 1987, Proceedings: Western Michigan University, p. II.

1989. Effects of ground-water withdrawals for irrigation on the quality of the Straight River, north-central Minnesota: U.S. Geological Survey Open-File Report 89-252, 2 p.

1990, Effects of ground-water withdrawal for irrigation and quality of Straight River, north-central Minnesota [abs.]: Transferring Models to Users, Denver, Colorado, November 4-9, 1990, Proceedings: American Water Resources Association, p. 1. 
Stoner, J.D., 1985, Simulation of ground-water flow near a former wood-treating waste site in Fridley, MinnesotaPart 1l. A practical application of an analytic-element model [ats.]: Annual Midwest Ground Water Conference, 30th, St. Paul, Minnesota, October 23-25, 1985 [Proceedings], p. 18.

- 1991, National Water-Quality Assessment Program — Red River of the North: U.S. Geological Survey OpenFile Report 91-151, 2 p.

Stoner, J.D., Brigham, M.E., and Cowdery, T.K., 1994, Water-quality in surficial glacial-deposit aquifers in the Red River of the North drainage basin, Minnesota, North Dakota, and South Dakota [abs.]: Midwest Ground Water Conference, 39th, Bismarck, North Dakota, October 16-18, 1994 [Proceedings], p. 15.

Stoner, J.D., and Lorenz, D.L., 1992, Water quality assessment strategy for the Red River of the North Basin. North Dakota, South Dakota, and Minnesota [abs.]: North Dakota Water Quality Symposium, Bismarck. North Dakota. March 25-26, 1992, Proceedings: North Dakota State University Extension Service, p. 291.

Stoner, J.D., and Schoenberg, M.E., 1989, Preliminary evaluation of effects of ground-water withdrawals on Mississippi River flow near the Twin Cities metropolitan area, Minnesota [abs.]: Water supply issues in the Metropolitan Twin Cities area-Planning for the Future Droughts and Population Growth, St. Paul, Minnesota, October 25, 1988, Proceedings: Minnesota Water Resources Research, p. 5-6.

Stoner, J.D., and Streitz, A.R., 1987, Locating confined aquifers in glacial drift with seismic reflection methods, western Minnesota [abs.]: Annual Meeting of the Geological Society of America, North Central Section, 21 st, St. Paul, Minnesota, April 30-May 1, 1987, Proceedings: Geological Society of America, p. 248.

Straka, G.C., and Miller, W.A., 1963, Graphs of ground-water levels in Minnesota, 1957-1961: Minnesota Department of Conservation, Division of Waters Bulletin 18, $58 \mathrm{p}$.

Straka, G.C., and Schneider, Robert, 1957, Graphs of ground water levels in Minnesota through 1956: Minnesota Department Conservation, Division of Waters Bulletin 9, $42 \mathrm{p}$.

Stoner, J.D., Brigham, M.E., and Cowdery, T.K., 1994, Water quality in surficial glacial-deposit aquifers in the Red River of the North drainage basin, Minnesota, North Dakota, and South Dakota [abs.]: Midwest Ground Water Conference, 39th, Bismarck, North Dakota, October 16-18, 1994 [Proceedings], p. 15.

Thomas, H.E., and Schneider, W.J., 1970, Water as an urban resource and nuisance: U.S. Geological Survey Circular 601-D, 9 p.

Thompson, G.L., 1965, Hydrology of melt-water channels in southwestern Minnesota: U.S. Geological Survey Water-Supply Paper 1809-K, 11 p.

Tornes, L.H., Puckett, L.J., Stoner, J.D., and Brigham, M.E., 1994 The effect of riparian wetlands in reducing nitrate nitrogen from a sand and gravel aquifer to a stream [abs.]: American Geophysical Union 1994 Fall Meeting, San Francisco, California, December 5-9, 1994, Proceedings: American Geophysical Union, p. 261.

Trescott, P.C., Pinder, G.F., and Larson, S.P., 1976, Finite-difference model for aquifer simulation in two dimensions with results of numerical experiments: U.S. Geological Survey Techniques of Water-Resources Investigations, book 7, chap. C1, $116 \mathrm{p}$.

Trotta, L.C., 1985, The potential for contamination of ground water based on hydrogeology-A geographic information system application [abs.]: Annual Midwest Ground Water Conference, 30th, St. Paul, Minnesota, October 23-25, 1985 [Proceedings], p. 19.

1987, Ground water withdrawals in Minnesota [abs.], in Zaporozec, A., ed., Annual Midwest Ground Water Conference, 32nd, Madison, Wisconsin, October 28-30, 1987 [Proceedings]. 
1988, Inventory of interbasin water transfer in Minnesota, in Symposium on Water Use Data for Water Resources Management, Bethesda, Maryland, August 1988, Proceedings: American Water Resources Association, p. 93-105.

- 1988, Inventory of interbasin water transfers in Minnesota: U.S. Geological Survey Open-File Report 88-466. $14 \mathrm{p}$.

1990, Minnesota water supply and use, in Carr, J.E., Chase, E.B., Paulson, R.W., and Moody, D.W., compilers, National Water Summary 1987: U.S. Geological Survey Water-Supply Paper 2350, p. 313-320.

1991, Water use in Minnesota, 1985: State of Minnesota Department of Natural Resources Water Use Map Series, 1 sheet.

Trotta, L.C., and Horn, M.S., 1990, Importance of return flow as a component of water use: U.S. Geological Survey Open-File Report 90-179, 2 p.

Trotta, L.C., and Lorenz, D.L., 1993, Comparison of maps showing the depth to water table (Dakota County, Minnesota) prepared by traditional GIS methods [abs.]: Geographic Information Systems and Water Resources, Mobile, Alabama, March 14-17, 1993, Proceedings: American Water Resources Association, p. 52.

U.S. Geological Survey, 1974, Status of projects in Minnesota 1974-75 fiscal years: U.S. Geological Survey, 49 p.

1975, Status of projects in Minnesota, fiscal years 1975-76: U.S. Geological Survey, 55 p.

1976, Hydrologic unit map-1974, State of Minnesota: U.S. Geological Survey, 1 sheet, scale 1:500,000.

1976, Status of projects in Minnesota, fiscal years 1976 and 1977: U.S. Geological Survey, 36 p.

1977. Status of projects in Minnesota, fiscal years 1977 and 1978: U.S. Geological Survey, 59 p.

- 1983, Quality assurance plan for the ground-water program of the Minnesota District: Unpublished report on file with U.S. Geological Survey Mounds View, Minnesota, $40 \mathrm{p}$.

1984, Ground-water contamination by crude petroleum at the Bemidji, Minnesota research site-Compilation of resource documents and project plan March 1984, variously paged.

VanVoast, W.A., 1969, Ground water for irrigation near Lake Emily, Pope County, west-central Minnesota: U.S. Geological Survey Open-File Report, 29 p.

1969, Profiles of regional ground-water flow in glacial deposits in Minnesota based on existing well data, in Annual Engineering Geology and Soils Engineering Symposium, 7th, Moscow, Idaho [Proceedings], p. 84-100.

- 1971, Ground water for irrigation in the Brooten-Belgrade area, west-central Minnesota: U.S. Geological Survey Water-Supply Paper 1899-E, 24 p.

1971, Ground water for irrigation near Lake Emily, Pope County, west-central Minnesota: U.S. Geological Survey Water-Supply Paper 1899-J, 28 p.

VanVoast, W.A., Broussard, W.L., and Wheat, D.E.. 1972, Water resources of the Minnesota River-Hawk Creek watershed, southwestern Minnesota: U.S. Geological Survey Hydrologic Investigations Atlas HA-391, 3 sheets, scale $1: 250,000$.

VanVoast, W.A., Jerabek, L.A., and Novitzki, R.P., 1970, Water resources of the Redwood River watershed, southwestern Minnesota: U.S. Geological Survey Hydrologic Investigations Atlas HA-345, 3 sheets.

VanVoast, W.A., and Novitzki, R.P., 1968, Ground-water flow related to streamflow and water quality: Water Resources Research, v. 4, no. 4, p. 769-775. 
Wanty, R.B., Tuttle, M.L., Landon, M.K., Delin, G.N., and Bohlke, J.K., 1993, Geochemistry of nitrogen in a farmed watershed near Princeton, Minnesota [abs.], in Morganwalp, D.W., and Aronson, D.A., compilers, U.S. Geological Survey Toxic Substances Hydrology Program-Abstracts of the technical meeting, Colorado Springs, Colorado, September 20-24, 1993: U.S. Geological Survey Open-File Report 93-454, p. 93.

Winter, T.C., 1972, An approach to the design of statewide or regional ground water information systems: Water Resources Research, v. 8, no. 1, p. 222-230.

1973, Hydrogeology of glacial drift, Mesabi Iron Range, northeastern Minnesota: U.S. Geological Survey Water-Supply Paper 2029-A, 23 p.

1974, The natural quality of ground water in Minnesota: Minnesota Department of Natural Resources Bulletin 26, $25 \mathrm{p}$.

Winter, T.C., Bidwell, L.E., and Maclay, R.W., 1969, Water resources of the Otter Tail River watershed, westcentral Minnesota: U.S. Geological Survey Hydrologic Investigations Atlas HA-296, 4 sheets.

1970, Water resources of the Wild Rice River watershed, northwestern Minnesota: U.S. Geological Survey Hydrologic Investigations Atlas HA-339, 4 sheets, scale 1:250,000.

Winter, T.C., Cotter, R.D., and Young, H.L., 1973, Petrography and stratigraphy of glacial drift, Mesabi-Vermillion Iron Range area, northeastern Minnesota: U.S. Geological Survey Bulletin 1331-C, 41 p.

Winter, T.C., Maclay, R.W., and Pike, G.M., 1967, Water resources of the Roseau River watershed, northwestern Minnesota: U.S. Geological Survey Hydrologic Investigations Atlas HA-241, 3 sheets, scale 1:250,000.

Winter, T.C., and Norvitch, R.F., 1972, Field trip guidebook for hydrogeology of the Twin Cities Artesian Basin: Minnesota Geological Survey Guidebook 8, 35 p.

Winter, T.C., and Pfannkuch, H.O., 1976, Hydrogeology of a drift-filled bedrock valley near Lino Lakes, Anoka County, Minnesota: U.S. Geological Survey Journal of Research, v. 4, no. 3, p. 267-276.

Winterstein, T.A., 1982, Annotated report and data inventory for the Mississippi and Minnesota Rivers, MinneapolisSt. Paul metropolitan area: U.S. Geological Survey Open-File Report 82-869, 99 p.

1986, Water-resources activities of the U.S. Geological Survey in the Red River Valley, Minnesota fiscal year 1986: U.S. Geological Survey, 32 p.

Wolf, R.J., 1976. Buried aquifers in the Brooten-Belgrade and Lake Emily areas, west-central Minnesota - Factors related to developing water for irrigation: U.S. Geological Survey Water-Resources Investigations Report 76$100,72 \mathrm{p}$.

1981, Hydrogeology of the Buffalo aquifer, Clay and Wilkin Counties, west-central Minnesota: U.S. Geological Survey Water-Resources Investigations Report 81-4, 83 p.

Wolf, R.J., Ruhl, J.F., and Adolphson, D.G., 1983, Hydrogeologic and water-quality characteristics of the Mount Simon-Hinckley aquifer, southeast Minnesota: U.S. Geological Survey Water-Resources Investigations Report 83-4031, 2 sheets.

Woodward, D.G., 1982, Effects of the Mississippi River system on ground-water flow in southeastern Minnesota [abs.]: Annual Meeting of Mississippi River Research Consortium, 15th, LaCrosse, Wisconsin, April 14-16, 1982, Proceedings: Mississippi River Research Consortium, p. 38.

1984. Areal lithologic changes in bedrock aquifers in southeastern Minnesota as determined from naturalgamma borehole logs methods, in Nielsen, D.M., and Curl, Mary, eds., Conference on Surface and Borehole Geophysical Investigations, San Antonio, Texas, February 7-9, 1984, Proceedings: National Water Well Association/Environmental Protection Agency, p. 788-800. 
1984, Minnesota ground-water resources, in U.S. Geological Survey National Water Summary 1984: U.S. Geological Survey Water-Siupply Paper 2275, p. 261-268.

1984, The study of buried drift aquifers in Minnesota by seismic geophysical methods: U.S. Geological Survey Open-File Report, 2 p.

1985, Trends in municipal-well installations and aquifer utilization in southeastern Minnesota, 1880-1980:

U.S. Geological Survey Water-Resources Investigations Report 83-4222, 99 p.

1986, Hydrogeologic framework and properties of regional aquifers in the Hollandale Embayment, southeastern Minnesota: U.S. Geological Survey Hydrologic Investigations Atlas HA-677, 2 sheets, scales $1: 1,000,000$ and $1: 2,000,000$.

Woodward, D.G., and Anderson, H.W., Jr., 1984, Hydrogeologic and water-quality characteristics of the Cretaceous aquifer, southwestern Minnesota: U.S. Geological Survey Water-Resources Investigations Report 84-4153, 2 sheets.

Woodward, D.G., and Delin, G.N., 1982, Potentiomentric surface of regional aquifers in the Hollandale Embayment, southeastern Minnesota [abs.]: EOS, Transactions, American Geophysical Union, v. 63, no. 33, p. 612. 


\section{Surface Water}

Adolphson, D.G., and Jannis, J.A., 1978, Status of projects in Minriesota, fiscal year 1978: U.S. Geological Survey, $101 \mathrm{p}$.

Almendinger, J.E., and Leete, Jeanette, 1994, Hydrology, geochemistry, and substrate of calcareous fens in the Minnesota River Basin [abs.]: Minnesota Water '94-Managing Minnesota's Rivers and Watersheds, Minneapolis, Minnesota, Apriil 21-22, 1994 [Proceedings], p. 7.

Amos, G.L., 1994, Water-resources activities of the U.S. Geological Survey Minnesota District, 1993 water year: U.S. Geological Survey Open-File Report 94-338, 72 p.

Amos, G.L., and Winterstein, T.A., 1993, Water-resources activities of the U.S. Geological Survey in Minnesota, 1991: U.S. Geological Survey Open-File Report 93-65, 73 p.

Anderson, D.B., 1973, Drainage ditch inventory, State of Minnesota: Unpublished report on file with the U.S. Geological Survey in Mounds View, Minnesota, 230 p.

Anderson, D.B., and Schwob, H.H., 1970, Floods of April-May 1969 in upper midwestern United States: U.S. Geological Survey Open-File Report, 555 p.

Anderson, H.W., Jr., Broussard, W.L., Farrell, D.F., and Felsheim, P.E., 1976, Water resources of the Rock River watershed, southwestern Minnesota: U.S. Geological Survey Hydrologic Investigations Atlas HA-555, 3 sheets, scale $1: 250,000$.

Anderson, H.W., Jr., Broussard, W.L., Farrell, D.F., and Hult, M.F., 1976, Water resources of the Des Moines River watershed, southwestern Minnesota: U.S. Geological Survey Hydrologic Investigations Atlas HA-553, 3 sheets, scales 1:250,000 and 1:500,000.

Anderson, H.W., Jr., Farrell, D.F., and Broussard, W.L., 1974, Water resources of the Blue Earth River watershed, south-central Minnesota: U.S. Geological Survey Hydrologic Investigations Atlas HA-525, 3 sheets, scale 1:500,000.

-1974, Water resources of the lower Minnesota River watershed, south-central Minnesota: U.S. Geological Survey Hydrologic Investigations Atlas HA-526, 3 sheets, scale 1:500,000.

Anderson, H.W., Jr., Farrell, D.F., Broussard, W.L., and Felsheim, P.E., 1974, Water resources of the Cannon River watershed, southeastern Minnesota: U.S. Geological Survey Hydrologic Investigations Atlas HA-522, 3 sheets, scales $1: 250,000$ and $1: 500,000$.

Anderson, H.W., Jr., Farrell, D.F., Broussard, W.L., and Hult, M.F., 1975, Water resources of the Zumbro River watershed, southeastern Minnesota: U.S. Geological Survey Hydrologic Investigations Atlas HA-543, 3 sheets. scale 1:250,000.

Arntson, A.D., and Lorenz, D.L., 1987, Low-flow frequency characteristics for continuous-record streamflow stations in Minnesota: U.S. Geological Survey Water-Resources Investigations Report 86-4353, 15 p.

Arntson, A.D., and Tornes, L.H., 1985, Rainfall-runoff relationship and water-quality assessment of Coon Creek watershed, Anoka County, Minnesota: U.S. Geological Survey Water-Resources Investigations Report 84-4013, $97 \mathrm{p}$.

Ayers, M.A., Brown, R.G., and Oberts, G.L., 1985, Runoff and chemical loading in small watersheds in the Twin Cities metropolitan area, Minnesota: U.S. Geological Survey Water-Resources Investigations Report 85-4122, $35 \mathrm{p}$.

Ayers, M.A., Payne, G.A., and Have, M.R., 1980, Effects of urbanization on the water quality of lakes in Eagan, Minnesota: U.S. Geological Survey Water-Resources Investigations Report 80-71, 42 p. 
Ayers, M.A., Payne, G.A., and Oberts, G.L.. 1980, Quality of runoff from small watersheds in the Twin Cities metropolitan area, Minnescita - A project plan: U.S. Gcological Survey Open-File Report 80-592, 31 p.

Bidwell, L.E., Winter, T.C., and Maclay, R.W., 1970. Water resources of the Red Lake River watershed, northwestern Minnesota: U.S. Geological Survey Hydrologic Investigatıons Atlas HA-346, 4 sheets, scales $1: 500,000$ and $1: 250,000$.

Brigham, M.E. 1994, Pesticides detected in surface waters and fish of the Red River of the North drainage basin [abs.]: North Dakota Water-Quality Symposium, 4th biennial, Fargo, North Dakota, March 30-31, 1994. Proceedings: North Dakota State University Extension Service, p. 26.

1994. Pesticides detected in surface waters and fish of the Red River of the North drainage basin, in North Dakota Water-Quality Symposium, 4th biennial, Fargo, North Dakota, March 30-31, 1994, Proceedings: North Dakota State University Extension Service, p. 256-269.

Brigham, M.E., Tornes, L.H., and Lorenz, D.L., 1994, Load estimates for pesticides in the Red River of the North drainage basin [abs.]: American Geophysical Union 1994 Fall Meeting, San Francisco, California, December 59. 1994, Proceedings: American Geophysical Union, p. 230.

Broussard, W.L., Anderson, H.W., Jr., and Farrell, D.F., 1973, Water resources of the Cottonwood River watershed, southeastern Minnesota: U.S. Geological Survey Hydrologic Investigations Atlas HA-466, 3 sheets, scales, 1:253,400, 1:500,000, and 1:250,000.

Broussard, W.L., Farrell, D.F., Anderson, H.W., Jr., and Felsheim, P.E., 1975, Water resources of the Root River watershed, southeastern Minnesota: U.S. Geological Survey Hydrologic Investigations Atlas HA-548, 3 sheets, scale $1: 250.000$.

Brown, R.G., 1984, Effects of an urban wetland on sediment and nutrient loads in runoff: Wetlands, v. 4, p. 147-158.

1984, Hydrologic effects of impoundments in Sherburne National Wildlife Refuge, Minnesota: U.S. Geological Survey Water-Resources Investigations Report 84-4175, 20 p.

1984, Precipitation and streamflow data-Collections techniques, in Understanding Watershed and Lake Management Conference, Bloomington, Minnesota, March 23, 1984 [Proceedings], p. 18-29.

1984, Relationship between quantity and quality of storm runoff and various watershed, characteristics in Minnesota, USA, in International Conference on Urban Storm Drainage, 3rd, Goteborg, Sweden, June 4-8, 1984 [Proceedings]. p. 79[-799.

1985, Effects of wetlands on quality of runoff entering lakes in the Twin Cities metropolitan area, Minnesota: U.S. Geological Survey Water-Resources Investigations Report 85-4170, $32 \mathrm{p}$.

-1985. Errors associated with estimating ground-water flow and phosphorus flux components in hydrologic and phosphorous budgets of lakes [abs.]: Annual Midwest Ground Water Conference, 30th, St. Paul, Minnesota, October 23-25, 1985 [Proceedings], p. 3.

1985, Hydrologic factors affecting lake-level fluctuations in Big Marine Lake, Washington County, Minnesota: U.S. Geological Survey Water-Resources Investigations Report 85-4176, 23 p.

- 1986, Errors in estimating ground-water components of hydrologic and phosphorus budgets of lakes, in Subitzky, Seymour, ed., Selected papers in hydrologic sciences 1986: U.S. Geological Survey Water-Supply Paper 2310, p. 53-64.

1987, Effects of wetland channelization of storm runoff in Lambert Creek, Ramsey County, Minnesota: National Wetlands Symposium of Wetland Hydrology, Chicago, lllinois, September 16-18, 1987 [Proceedings], p. 130-136. 
Brown, R.F., and Cotter, R.D., 1963, Water and the Minnesota Iron Range: U.S. Geological Survey, 16 p.

Brown, R.G., Patterson, G.L., and Stark, J.R., 1986, Ground-water and surface-water interaction in wetlands-Comparisons and contrasts [abs.]: Wisconsin Section Annual Meeting, Wisconsin Dells, Wisconsin, April 3-4, 1986, Proceedings: American Water Resources Association, p. 1.

Brown, R.G., and Stark, J.R., 1989, Hydrologic and water quality characteristics of a wetland receiving wastewater effluent in St. Joseph, Minnesota: Wetlands, v. 9, no. 2, p. 191-206.

Brown, R.G., and Stark, J.R., and Patterson, G.L., 1985, Ground-water and surface-water interactions in Minnesota and Wisconsin wetlands, in Hook, D.D., McKee, W.H., Jr., Smith, H.K., Gregory, J., Burrell, V.G., Jr., DeVee M.,R., Sojka, R.E., Gilberts, S., Banks, R., Stolzy, L.H., Brooks, C., Matthews, T.D., and Shear, T.H., The ecology and management of wetlands: Portland, Oregon, Timber Press, p. 176-180.

Carlson, G.H., 1971, Flooded area of Lake St. Croix Beach, Minnesota: U.S. Geological Survey Open-File Report, $4 \mathrm{p}$.

— 1971, Flooded area of Lakeland Shores, Minnesota: U.S. Geological Survey Open-File Report, 5 p.

—1971, Flooded area of Montevideo, Minnesota: U.S. Geological Survey Open-File Report, 6 p.

1991, Minnesota floods and drought, in Paulson, R.W., Chase, E.B., Williams, J.S., and Moody, D.W., compilers, National Water Summary 1988-89: U.S. Geological Survey Water-Supply Paper 2375, p. 345-352.

1994, Changes in 100-year flood discharge estimates with varying period of record on Minnesota streams [abs.]: Minnesota Water '94 Managing Minnesota's Rivers and Watersheds, Minneapolis, Minnesota, April 21-22, 1994 [Proceedings], p. 11.

Carison, G.H., and Guetzkow, L.C., 1980, Flood-plain areas of the Mississippi River mile 866.8 to mile 888.0: U.S. Geological Survey Water-Resources Investigations Report 80-972, 8 sheets.

Carlson, G.H., and Gunard, K.T., 1979, Small stream flood investigations in Minnesota, October 1958 to September 1977: U.S. Geological Survey Open-File Report 79-1061, 194 p.

Carlson, G.H., Zandlo, J.A., Nindles, D.B., and Sium, Ogbazghi, 1990, Minnesota floods and drought, in Paulson, R.W., Chase, E.B., Roberts, R.S., and Moody, D.W., compilers, National Water Summary 1988-89: U.S. Geological Survey Water-Supply Paper 2375, p. 345-352.

Collier, C.R., 1974, An approximation of sediment yields from watersheds in Minnesota, in Winter Meeting, Chicago, Illinois, December 10-13, 1974, Proceedings: American Society of Agricultural Engineers, 9 p.

Cotter, R.D., and Bidwell, L.E., 1966, Water resources of the Pomme de Terre River watershed, west-central Minnesota: U.S. Geological Survey Hydrologic Investigations Atlas HA-220, 4 sheets, scale 1:250,000.

1968, Water resources of the Lac qui Parle River watershed, southwestern Minnesota: U.S. Geological Survey Hydrologic Investigations Atlas HA-269, 4 sheets, scale 1:250,000.

Cotter, R.D., Bidwell, L.E., Oakes, E.L., and Hollenstein, G.H., 1966, Water resources of the Big Stone Lake watershed, west-central Minnesota: U.S. Geological Survey Hydrologic Investigations Atlas HA-213, 4 sheets, scale $\mathrm{I}: 250,000$.

Cotter, R.D., Bidwell, L.E., VanVoast, W.A., and Novitzki, R.P., 1968, Water resources of the Chippewa River watershed, west-central Minnesota: U.S. Geological Survey Hydrologic Investigations Atlas HA-286, 4 sheets, scale $1: 250,000$.

Cotter, R.D., and Young, H.L., 1960, Municipal water supplies on the Mesabi and Vermillion Iron Ranges, northeastern Minnesota: U.S. Geological Survey Minnesota, Ground Water Series Basic Data Release 1, 61 p. 
Cotter, R.D., Young, H.L., Petri, R.L., and Prior, C.H., 1965, Ground and surface water in the Mesabi and Vermillion Iron Range area, northeastern Minnesota: U.S. Geological Survey Water-Supply Paper 1759-A, p. A1-A36.

- 1965, Water resources in the vicinity of municipalities on the central Mesabi Iron Range, northeastern Minnesota: U.S. Geological Survey Water-Supply Paper 1759-D, 20 p.

-1965, Water resources in the vicinity of municipalities on the east-central Mesabi Iron Range, northeastern Minnesota: U.S. Geological Survey Water-Supply Paper 1759-E, 23 p.

1965, Water resources in the vicinity of municipalities on the eastern Mesabi Iron Range, northeastern Minnesota: U.S. Geological Survey Water-Supply Paper 1759-F, 27 p.

1965, Water resources in the vicinity of municipalities on the west-central Mesabi Iron Range, northeastern Minnesota: U.S. Geological Survey Water-Supply Paper 1759-C, 21 p.

1965, Water resources in the vicinity of municipalities on the western Mesabi Iron Range, northeastern Minnesota: U.S. Geological Survey Water-Supply Paper 1759-B, 24 p.

Cowdery, T.K., and Brigham, M.E., 1992, Baseflow dissolved-solids loads to streams of the Red River of the North Basin, South Dakota, North Dakota, and Minnesota [abs.]: Annual Midwest Ground-Water Conference, 37th, Souix Falls, South Dakota, October 14-16, 1992 [Proceedings], p. 38.

Diedrich, M.M., and Jannis, J.A., 1980, Status of projects in Minnesota, fiscal year 1980: U.S. Geological Survey, $99 \mathrm{p}$.

- 1981, Status of projects in Minnesota, fiscal year 1981: U.S. Geological Survey, $58 \mathrm{p}$.

Ericson, D.W., Holmen, O.O., and Latkovitch, V.J., 1980, Flood of April-May 1979 in Red River of the North Basin. North Dakota and Minnesota: U.S. Geological Survey Water-Resources Investigations Report 80-1176, 2 sheets.

Ericson, D.W., Lindholm, G.F., and Helgesen, J.O., 1974, Water resources of the Rum River watershed, eastcentral Minnesota: U.S. Geological Survey Hydrologic Investigations Atlas HA-509, 3 sheets, scales 1:250,000 and $1: 500,000$.

1976, Water resources of the Rainey Lake watershed, northeastern Minnesota: U.S. Geological Survey Hydrologic Investigations Atlas HA-556, 2 sheets, scale 1:1,000,000.

Farrell, D.F., Broussard, W.L., Anderson, H.W., Jr., and Hult, M.F., 1975, Water resources of the Cedar River watershed, southeastern Minnesota: U.S. Geological Survey Hydrologic Investigations Atlas HA-552, 3 sheets, scale $1: 250,000$.

Ficke, J.F., and Hawkinson, R.O., 1975, The National Stream Quality Accounting Network (NASQAN)-Some questions and answers: U.S. Geological Survey Circular 719, 23 p.

Giacomini, E.G., Wolf, R.J., Payne, G.A., and Adolphson, D.G., 1980, Hydrologic characteristics of Elim, Skunk, and Deer Creeks, Upper Nemadji River Basin, Minnesota: U.S. Geological Survey Open-File Report 80-47, 65 p.

Goldstein, R.M., Simon, T.P., Bailey, P.A., Ell, Michael, Pearson, Eric, Schmidt, Konrad, and Enblom, J.W., 1994. Concepts for an index of biotic integrity for streams of the Red River of the North Basin [abs.]: North Dakota Water-Quality Symposium, 4th biennial, Fargo, North Dakota, March 30-31, 1994, Proceedings: North Dakota State University Extension Service, p. 19.

1994, Concepts for an index of biotic integrity for streams of the Red River of the North Basin, in North Dakota Water-Quality Symposium, 4th biennial, Fargo, North Dakota, March 30-31, 1994, Proceedings: North Dakota State University Extension Service, p. 169-180. 
Groschen, G.E., and Alexander, E.C., Jr., 198I, Geochemistry of Williams Lake, Hubbard County, Minnesota [abs.]: EOS, Transactions, American Geophysical Union, v. 63, no. 33, p. 613.

1982, Geochemistry of Williams Lake, Hubbard County, Minnesota [abs.]: EOS, Transactions, American Geophysical Union, v. 63, no. 33, p. 613.

Guetzkow, L.C., 1973, Small stream flood investigations in Minnesota, October 1958 to September 1971: U.S. Geological Survey Open-File Report, 159 p.

1977, Techniques for estimating magnitude and frequency of floods in Minnesota: U.S. Geological Survey Water-Resources Investigations Report 77-31, $33 \mathrm{p}$.

Guetzkow, L.C., and Carlson, G.H., 1969, Small stream flood investigations in Minnesota, October 1958 to September 1967: U.S. Geological Survey Open-File Report, 174 p.

1973. Flood-plain areas of the lower Minnesota River: U.S. Geological Survey Open-File Report 74-15, 12 sheets.

Guetzkow, L.C., and Gunard, K.T., 1967. Small stream flood investigations in Minnesota, October 1958 to September 1965: U.S. Geological Survey Open-File Report, 162 p.

1975, Small stream flood investigations in Minnesota, October 1958 to September 1973: U.S. Geological Survey Open-File Report, 161 p.

1977, Small stream flood investigations in Minnesota, October 1958 to September 1975: U.S. Geological Survey Open-File Report 77-39, $161 \mathrm{p}$.

Gunard, K.T., 1971, Flooded area of St. Mary’s Point, Minnesota: U.S. Geological Survey Open-File Report, 6 p.

-1985. Minnesota surface-water resources, in, Woody, D.W., Chase, E.B., and Aronson, D.A., compilers, National Water Summary 1985: U.S. Geological Survey Water-Supply Paper 2300, p. 285-294.

Gunard, K.T., and Guetzkow, L.C., 1971, Small stream flood investigations in Minnesota, October 1958 to September 1969: U.S. Geological Survey Open-File Report, 174 p.

Gunard, K.T., and Smith, C.J., 1982, Small stream flood investigations in Minnesota, October 1958 to September 1980: U.S. Geological Survey Open-File Report 82-433, 221 p.

Guy, H.P., 1970, Sediment problems in urban areas: U.S. Geological Survey Circular 601-E, 8 p.

Have, M.R., 1975, A water-quality assessment of the Burham Creek watershed, Polk County, Minnesota: U.S. Geological Survey Open-File Report 75-647, 15 p.

1975. Some limnological aspects of 20 selected lakes in Eagan and Apple Valley, Minnesota: U.S. Geological Survey Open-File Report 75-528, 44 p.

- 1980, Water quality of Rogers Lake, Dakota County, Minnesota: U.S. Geological Survey Water-Resources Investigations Report 80-5, $35 \mathrm{p}$.

1991, Selected water-quality characteristics in the Upper Mississippi River Basin, Royalton to Hastings, Minnesota: U.S. Geological Survey Water-Resources Investigations Report 88-4053, 152 p.

- 1991, Streamflow entering and leaving Lake Bemidji, Beltrami County, Minnesota, July 1989-September 1989: U.S. Geological Survey Open-File Report 91-499, 25 p.

Have, M.R., Payne, G.A., and Ayers, M.A., 1981, Water quality of Alimagnet, Farquar, and Long Lakes in Apple Valley, Minnesota: U.S. Geological Survey Water-Resources Investigations Report 81-40, 38 p. 
Have, M.R., and Tornes, L.H. 1987, Water quality data for Orwell Reservoir and Otter Tail River near Fergus Falls, Minnesota: U.S. Geological Survey Open-File Report 87-537, 48 p.

Hein, M.D., 1982, Status of water-resources projects in Minnesota fiscal year 1982: U.S. Geological Survey, 61 p.

Helgesen, J.O., Ericson, D.W., and Lindholm, G.F., 1975, Water resources of the Mississippi and Sauk Rivers watershed, central Minnesota: U.S. Geological Survey Hydrologic Investigations Atlas HA-534, 3 sheets, scale $1: 250,000$.

Helgesen, J.O., Lindholm, G.F., Broussard, W.L., and Ericson, D.W., 1973, Water resources of the Kettle River watershed, east-central Minnesota: U.S. Geological Survey Hydrologic Investigations Atlas HA-437, 4 sheets, scale $1: 250,000$.

Helgesen J.O., Lindholm, G.F., and Ericson, D.W., 1975, Water resources of the Lake of the Woods watershed, north-central Minnesota: U.S. Geological Survey Hydrologic Investigations Atlas HA-544, 2 sheets, scale $1: 500,000$.

1976, Water resources of the Little Rock River watershed, northeastern Minnesota: U.S. Geological Survey Hydrologic Investigations Atlas HA-551, 2 sheets, scale 1:500,000.

Hicks, J.K., 1974, Coon Rapids pool hydrographic study: U.S. Geological Survey Open-File Report, 6 p.

Horn, M.A., 1981, Data for water resources management in Minnesota, in Allee, D.J., Dworsky, L.B., and North, R.M., eds., Unified River Basin Management-Stage II, American Water Resources Association Symposium, Atlanta, Georgia, October 4-8, 1981, Proceedings: American Water Resources Association, p. 429-441.

1986, Development of a water-use data system in Minnesota: U.S. Geological Survey Water-Resources Investigations Report 85-4306. $59 \mathrm{p}$.

Jannis, J.A.; 1983, Status of water-resources projects in Minnesota, fiscal year 1983: U.S. Geological Survey, 74 p. 1984, Status of projects in Minnesota, fiscal year 1984: U.S. Geological Survey Open-File Report, 84 p.

- 1986, Water-resources activities of the U.S. Geological Survey in Minnesota, fiscal year 1985: U.S. Geological Survey Open-File Report 86-133, 83 p.

Jannis, J.A., and Diedrich, M.M., 1979, Status of projects in Minnesota, fiscal year 1979: U.S. Geological Survey Open-File Report, $79 \mathrm{p}$.

Jaques, J.E., and Lorenz, D.L., 1988, Techniques for estimating the magnitude an frequency of floods in Minnesota: U.S. Geological Survey Water-Resources Investigations Report 87-4170, 48 p.

Komor, S.C., 1992, Bidirectional sulfate diffusion in saline-lake sediments-Evidence from Devil's Lake: Geology, v. 20 , no. 4 , p. $319-322$.

1994, Bottom-sediment chemistry in Devil's Lake, northeast North Dakota: Sedimentology and Geochemistry of Modern and Ancient Saline Lakes, no. 50, p. 21-32.

1994. Gcochemistry and hydrology of a calcareous fen within the Savage Fen wetlands complex, Minnesota, USA: Geochimica et Cosmochimica Acta, v. 58, no. 16, p. 3353-3367.

1994, Geochemistry and hydrology of Savage Fen, a calcareous fen in the Minnesota River Valley [abs]: Minnesota Water '94 Managing Minnesota's Rivers and Watersheds, Minneapolis, Minnesota, April 21-22, 1994 [Proceedings], p. 9.

LaBaugh, J.W., Groschen, G.E., and Winter, T.C., 1981, Limnological and geochemical survey of Williams Lake, Hubbard County, Minnesota: U.S. Geological Survey Water-Resources Investigations Report 81-41, 38 p. 
Langford, R.H., 1964, Chemical quality of the water resources Kittson, Marshall, and Roseau Counties, Minnesota: Unpublished report on file with U.S. Geological Survey in Mounds View, Minnesota, 168 p.

Larson, S.P., Mann, W.B., IV, Steele, T.D., and Susag, R.H., 1974, Time-trend and river-reach assessments in water quality of the Mississippi River, Minneapolis-St. Paul, metropolitan area, Minnesota [abs.]: EOS, Transactions, American Geophysical Union, v. 55, no. 12, p. 1114.

1976, Graphic and analytical methods for assessments of stream-water quality-Mississippi River in the Minneapolis-St. Paul metropolitan area, Minnesota: U.S. Geological Survey Water-Resources Investigations Report 76-94, 55 p.

Latkovich, V.J., 1979, Flood of July 5-7, 1978 on the South Fork Zumbro River at Rochester, Minnesota: U.S. Geological Survey Water-Resources Investigations Report 79-1583, 1 sheet.

-1979, Hydrologic data for floods of July 1978 in southeast Minnesota and southwest Wisconsin: U.S. Geological Survey Open-File Report 79-1166, 29 p.

Lindholm, G.F., 1968, Geology and water resources of the Hibbing area, northeastern Minnesota: U.S. Geological Survey Hydrologic Investigations Atlas HA-280, 3 sheets, scale 1:24,000.

Lindholm, G.F., Ericson, D.W., Broussard, W.L., and Hult, M.F., 1979, Water resources of the St. Louis River watershed, northeastern Minnesota: U.S. Geological Survey Hydrologic Investigations Atlas HA-586, 3 sheets.

Lindholm, G.F., Farrell, D.F., and Helgesen, J.O., 1974, Water resources of the Crow River watershed, southcentral Minnesota: U.S. Geological Survey Hydrologic Investigations Atlas HA-528, 3 sheets, scale 1:500,000.

Lindholm, G.F., Helgesen, J.O., Broussard, W.L., and Farrell, D.F., 1974, Water resources of the lower St. Croix River watershed, east-central Minnesota: U.S. Geological Survey Hydrologic Investigations Atlas HA-490, 3 sheets, scales $1: 250,000$ and $1: 500,000$.

-1974. Water resources of the Snake River watershed, east-central Minnesota: U.S. Geological Survey Hydrologic Investigations Atlas HA-488, 3 sheets, scales 1:250,000 and 1:500,000.

Lindholm, G.F., Helgesen, J.O., and Ericson, D.W., 1976, Water resources of the Fork River watershed, northcentral Minnesota: U.S. Geological Survey Hydrologic Investigations Atlas HA-549, 2 sheets, scale 1:500,000.

Lindholm, G.F., Oakes, E.L., Ericson, D.W., and Helgesen, J.O., 1972, Water resources of the Crow Wing River watershed, central Minnesota: U.S. Geological Survey Hydrologic Investigations Atlas HA-380, 4 sheets, scale 1:250,000.

Lindskov, K.L., 1975, Data summary of June-July 1975 floods in eastern North Dakota and northwestern Minnesota: U.S. Geological Survey Open-File Report 75-565, 15 p.

1977. Low-flow characteristics of Minnesota streams: U.S. Geological Survey Water-Resources Investigations Report 77-48, $197 \mathrm{p}$.

Lorenz, D.L., 1990, A method for describing stream-drainage system topology in a geographic information system [abs.], in Balthrop, B.H., and Baker, E.G., compilers, U.S. Geological Survey National Computer Technology Meeting-Program and abstracts, San Antonio, Texas, May 7-11, 1990: U.S. Geological Survey Open-File Report 90-161, p. 22.

-1991, Describing stream-drainage systems using a geographic information system [abs.]: Water Management of River Systems, New Orleans. Louisiana, September 8-13, 1991, Proceedings: American Water Resources Association, p. 285-286. 
1992, Integrating and aggregating data from stream-drainage systems using a geographic information system, in Wiltshire, D.A., ed., Selected papers in applied computer sciences 1992: U.S. Geological Survey Bulletin 2016, p. D1-D7.

Lorenz, D.L., and Payne, G.A., 1989, Selected data describing stream subbasins in the Redwood River Basin, southwestern Minnesota: U.S. Geological Survey Open-File Report 89-405, 5 p.

1991, Selected data for stream subbasins in the Le Sueur River Basin, south-central Minnesota: U.S. Geological Survey Open-File Report 91-62, 8 p.

1991, Selected data for stream subbasins in the Watonwan River Basin, south-central Minnesota: U.S. Geological Survey Open-File Report 91-61, 7 p.

1992, Physical characteristics of stream subbasins in the Blue Earth River Basin, south-central Minnesota and north-central Iowa: U.S. Geological Survey Open-File Report 91-512, 10 p.

1994, Physical characteristics of stream subbasins in the Pomme de Terre River Basin, west-central Minnesota: U.S. Geological Survey Open-File Report 93-47, 8 p.

Lorenz, D.L., Sanocki, C.A., and Winterstein, T.A., 1994, Physical characteristics of stream subbasins in the Lac qui Parle River Basin, southwestern Minnesota and eastern South Dakota: U.S. Geological Survey Open-File Report 93-46, $12 \mathrm{p}$.

Maclay, R.W., Bidwell, L.E., and Winter, T.C., 1969, Water resources of the Buffalo River watershed, west-central Minnesota: U.S. Geological Survey Hydrologic Investigations Atlas HA-307, 3 sheets, scale 1:250,000.

Maclay, R.W., Winter, T.C., and Bidwell, L.E., 1968, Water resources of the Mustinka and Bois de Souix Rivers watershed, west-central Minnesota: U.S. Geological Survey Hydrologic Investigations Atlas HA-272, 4 sheets. scale $1: 250,000$.

- 1972. Water resources of the Red River of the North drainage basin in Minnesota: U.S. Geological Survey Water-Resources Investigations Report 1-72, 129 p.

Maclay, R.W., Winter, T.C., and Pike, G.M., 1965, Water resources of the Middle River watershed, northwestern Minnesota: U.S. Geological Survey Hydrologic Investigations Atlas HA-201, 3 sheets, scale 1:250,000.

- 1967, Water resources of the Two Rivers watershed, northwestern Minnesota: U.S. Geological Survey Hydrologic Investigations Atlas HA-237, 4 sheets, scale 1:250,000.

Mann, W.B., IV, 1971, Flow characteristics of Minnesota streams: Minnesota Department of Natural Resources Technical Paper 4, $265 \mathrm{p}$.

Mann, W.B., IV, and Collier, C.R., 1970, A proposed streamflow data program for Minnesota: U.S. Geological Survey Open-File Report, 75 p.

Mann, W.B., IV, and McBride, M.S.. 1972, The hydrologic balance of Lake Sallie, Becker County, Minnesota: U.S. Geological Survey Professional Paper 800-D, p. 189-191.

McBride, M.S., 1976, Hydrology of lakes in the Minneapolis-St. Paul metropolitan area A summary of available data: U.S. Geological Survey Water-Resources Investigations Report 76-85, 317 p.

McGuinness, C.L., 1964, Generalized map showing annual runoff and productive aquifers in the conterminous United States: U.S. Geological Survey Hydrologic Investigations Atlas HA-194, 1 sheet, scale 1:5,000,000.

Minnesota Department of Conservation, 1961, Water resources of the Minneapolis-St.Paul metropolitan area: Minnesota Department of Conservation, Division of Waters Bulletin 11, 52 p. 
Mitton, G.B., 1991, Water quality data for Sauk Lake and tributaries near Sauk Center, Minnesota, 1988-89: U.S. Geological Survey Open-File Report 91-456, 57 p.

Moyle, J.B., 1956, Relationships between the chemistry of Minnesota surface waters and wildlife management: Journal of Wildlife Management, v. 20, no. 3, p. 303-320.

Myette, C.F., 1980, Hydrologic budget for Eagle Lake near Willmar, Minnesota: U.S. Geological Survey Open-File Report 80-163,13 p.

Nelson, Luanne, and Brown, R.G., 1983, Streamflow and water-quality data for wetland inflows and outflows in the Twin Cities metropolitan area, Minnesota, 1981-82: U.S. Geological Survey Open-File Report 83-543, 182 p.

Norvitch, R.F., Ross, T.G., and Brietkrietz, Alex, 1973, Water resources outlook for the Minneapolis-St. Paul metropolitan area, Minnesota: U.S. Geological Survey Open-File Report 73-203, 219 p.

Novitzki, R.P., VanVoast, W.A., and Jerabek, L.A., 1969, Water resources of the Yellow Medicine River watershed, southwestern Minnesota: U.S. Geological Survey Hydrologic Investigations Atlas HA-320, 3 sheets, scale $1: 250,000$.

Oakes, E.L., and Bidwell, L.E., 1968. Water resources of the Mississippi headwaters watershed, north-central Minnesota: U.S. Geological Survey Hydrologic Investigations Atlas HA-278, 4 sheets, scale 1:250,000.

Olcott, P.G., Ericson, D.W., Felsheim, P.E., and Broussard, W.L., 1978, Water resources of the Lake Superior watershed, northeastern Minnesota: U.S. Geological Survey Hydrologic Investigations Atlas HA-582, 2 sheets. scales $1: 500,000$ and $1: 1,000,000$.

Payne, G.A. 1977, Baseline water quality of Long Meadow Lake, Ponds AP-9 and AP-10 and Black Dog Creek. Hennepin and Dakota Counties, Minnesota: U.S. Geological Survey Open-File Report 77-424, 56 p.

- 1979, Water-quality reconnaissance of lakes in Voyageurs National Park, Minnesota: U.S. Geological Survey Open-File Report 79-556, $40 \mathrm{p}$.

1980, Baseline water quality of Schmidt, Hornbeam, and Horseshoe Lakes, Dakota County, Minnesota: U.S. Geological Survey Water-Resources Investigations Report 80-3, 38 p.

1983, Streamflow and suspended-sediment transport in Garvin Brook, Winona County, southeastern Minnesota-Hydrologic data for 1982: U.S. Geological Survey Open-File Report 83-212, 22 p.

1989, Flow characteristics of the Clearwater River and tributaries from Clearbrook to Plummer, northwestern Minnesota: U.S. Geological Survey Water-Resources Investigations Report 89-4045, 25 p.

1991, Sediment, nutrients, and oxygen demanding substances in the Minnesota River-Selected water-quality data, 1989-90: U.S. Geological Survey Open-File Report 91-498, 37 p.

1991, Water quality of lakes and streams in Voyageurs National Park, Minnesota, 1977-84: U.S. Geological Survey Water-Resources Investigations Report 88-4016, 95 p.

1994. Sources and transport of sediment, nutrients, and oxygen-demanding substances in the Minnesota River Basin, 1989-92: U.S. Geological Survey Water-Resources Investigations Report 93-4232, 71 p.

Payne, G.A., Ayers, M.A., and Brown, R.G., 1982, Quality of runoff from small watersheds in the Twin Cities metropolitan area, Minnesota Hydrologic data for 1980: U.S. Geological Survey Open-File Report 82-504, $289 \mathrm{p}$.

Prior, C.H., 1949, Magnitude and frequency of floods in Minnesota: Minnesota Department of Conservation, Division of Waters Bulletin 1, $128 \mathrm{p}$. 
Prior, C.H., and Hess, J.H., 1961, Floods in Minnesota magnitude and frequency: Minnesota Department of Conservation, Division of Waters Bulletin 12,142 p.

Prior, C.H., Schneider, Robert, and Durum, W.H., 1953, Water resources of the Minneapolis-St. Paul area, Minnesota: U.S. Geological Survey Circular 274, 49 p.

Rainwater, F.H., 1962, Stream composition of the conterminous United States: U.S. Geological Survey Hydrologic Investigations Atlas HA-61, 3 sheets.

Rickert, D.A., and Spieker, A.M., 1972, Real-estate lakes: U.S. Geological Survey Circular 601-G, 19 p.

Ropes, L.H., 1969, Ground-water resources of the St. James area, south-central Minnesota: U.S. Geological Survey Hydrologic Investigations Atlas HA-334, 1 sheet, scale 1:62,500.

Ropes, L.H., Brown, R.F., and Wheat, D.E., 1969, Reconnaissance of the Red Lake River, Minnesota: U.S. Geological Survey Hydrologic Investigations Atlas HA-299, 1 sheet, scale 1:250,000.

Ruhl, J.F.. 1989, Water resources of the Fond du Lac Indian Reservation, east-central Minnesota: U.S. Geological Survey Water-Resources Investigations Report 88-4114, $42 \mathrm{p}$.

- 1989, Water resources of the White Earth Indian Reservation, northwestern Minnesota: U.S. Geological Survey Water-Resources Investigations Report 89-4074, 73 p.

- 1990, Water resources of the Red Lake Indian Reservation, northwestern Minnesota: U.S. Geological Survey Water-Resources Investigations Report 90-4I63, 49 p.

Saboe, C.W., 1973, Flooded area of Stillwater, Minnesota: U.S. Geological Survey Open-File Report, 6 p.

Sanocki, C.A., and Krumrie, J.R., 1994, Physical characteristics of stream subbasins in the Chippewa River Basin, west-central Minnesota: U.S. Geological Survey Open-File Report 94-488, 16 p., 1 sheet, scale 1:100,000.

Schneider, W.J., Rickert, D.A., and Spieker, A.M., 1972, Role of water in urban planning and management: U.S. Geological Survey Circular 601-H, $10 \mathrm{p}$.

Schneider, W.J., and Spieker, A.M., 1969, Water for the cities-the outlook: U.S. Geological Survey Circular 601A, $6 \mathrm{p}$.

Schoenberg, M.E., 1989, Factors affecting water-supply potential of the Twin Cities metropolitan area aquifer system: Journal of the Minnesota Academy of Science, v. 55, no. 1, p. 38-47.

1989, Relation of ground-water flow in bedrock aquifers and the Mississippi and Minnesota Rivers, Minneapolis and St. Paul area, Minnesota: U.S. Geological Survey Open-File Report 89-268, 2 p.

Schoenberg, M.E., and Mitton, G.B., 1990, Monthly mean discharge at and between selected streamflow-gaging stations along the Mississippi, Minnesota and St. Croix Rivers, 1932-1987: U.S. Geological Survey Open-File Report 90-186, $36 \mathrm{p}$.

Schottler, S.P., Eisenreich, S.J., and Capel, P.D., 1990, Hydrologic and chemical controls on atrazine and alachlor in the Minnesota River [abs.]: EOS, Transactions, American Geophysical Union, v. 71, no. 43, p. 1330.

1991, Relations between water discharge and herbicide concentration in the Minnesota River, Minnesota, in Mallard, G.E., and Aronson, D.A., eds., U.S. Geological Survey Toxic Substances Hydrology ProgramProceedings of the technical meeting Monterey, California, March 11-15, 1991: U.S. Geological Survey WaterResources Investigations Report 91-4034, p. 338-342.

Siegel, D.I., 1981, Effect of snowmelt on the water quality of Filson Creek and Omaday Lake, northeastern Minnesota: U.S. Geological Survey Water-Resources Investigations Report 81-66, 81 p. 
1981, The effect of snow melt on water quality of Filson Creck and Omaday Lake, northeastern Minnesota: Water Resources Research, v. 17, no. 1, p. 238-242.

Siegel, D.I., and Winter, T.C., 1980, Hydrologic setting of Williams Lake, Hubbard County, Minnesota: U.S. Geological Survey Open-File Report 80-403, 56 p.

Skinner, J.V., 1986, Measurement of scour depth near bridge piers: U.S. Geological Survey Water-Resources Investigations Report 85-4106, $33 \mathrm{p}$.

1986, Sampling suspended sediment in ice-covered rivers: International Northern Research Basins Symposium, 6th, Michigan Technology University, January 26-30, 1986 [Proceedings], p. 105-108.

Smith, C.J., Payne, G.A., and Tornes, L.H., 1990, Effects of impoundments on water quality of streams in the Coteau des Prairie-Upper Minnesota River Basin: U.S. Geological Survey Water-Resources Investigations Report 90-4033, 67 p.

1990, Hydrologic and water-quality data for streams and impoundments in the Coteau des Prairie-Upper Minnesota River Basin: U.S. Geological Survey Open-File Report 88-84, 43 p.

Stark, J.R., 1992, Stream-aquifer relations along Straight River, Becker and Hubbard Counties, Minnesota [abs.]: Annual Midwest Ground Water Conference, 37th, Souix Falls, South Dakota, October 14-16, 1992

[Proceedings], p. 36.

1994, National Water-Quality Assessment Program for the Upper Mississippi River Basin: U.S. Geological Survey Open-File Report 94-101, 2 p.

1994, Plans for a water quality assessment of the Upper Mississippi River Basin [abs.]: Annual meeting of the Mississippi River Research Consortium, 26th, LaCrosse, Wisconsin, April 28-29, 1994 [Proceedings], p. 18.

1994, Plans for water-quality assessment of the Upper Mississippi River Basin [abs.]: Sustaining the Ecological Integrity of Large Floodplain Rivers-Application of Ecological Knowledge to River Management, LaCrosse, Wisconsin, July 12-15, 1994 [Proceedings], p. 157.

1994, Upper Mississippi River Basin water quality assessment [abs.]: Minnesota Water '94-Managing Minnesota's Rivers and Watersheds, Minneapolis, Minnesota, April 21-22, 1994 [Proceedings], p. 16.

Stark, J.R., Armstrong, D.S., and Zwilling, D.R., 1994, Stream-aquifer interactions in the Straight River area, Becker and Hubbard Counties, Minnesota: U.S. Geological Survey Water-Resources Investigations Report 94$4009,83 \mathrm{p}$.

Stark, J.R., and Brown, R.G., 1987, Hydrologic interactions in a wetland in Minnesota and Wisconsin [abs.]: Annual Meeting of the Geological Society of America, North Central Section, 21st, St. Paul, Minnesota, April 30-May 1, 1987, Proceedings: Geological Society of America, p. 247-248.

1987, Hydrology and water quality of a wetland used to receive wastewater effluent, St. Joseph, Minnesota, in National Wetland Symposium, Chicago, Illinois, September 16-18, 1987, Proceedings: Association of State Wetland Managers, Inc., p. 197-204.

Stark, J.R., and Payne, G.A., 1988, A comparison of hydrologic budgets of two wetlands in Minnesota and Wisconsin [abs.]: Annual Conference—Water for the Years Ahead, Quality and Quantity—1990 and Beyond, 24th, Milwaukee, Wisconsin, November 6-8, 1988, Proceedings: American Water Resources Association, p. 32.

Stark, J.R., and Zwilling, D.R., 1989, Effects of ground-water withdrawal for irrigation and quality of Straight River, north-central Minnesota [abs.]: Annual Midwest Ground Water Conference, 34th, Kalamazoo, Michigan, October 18-20, 1987, Proceedings: Western Michigan University, p. 11. 
-1989, Effects of ground-water withdrawals for irrigation on the quality of the Straight River, north-central Minnesota: U.S. Geological Survey Open-File Report 89-252, 2 p.

- 1990, Effects of ground-water withdrawal for irrigation and quality of Straight River, north-central Minnesota [abs.]: Transferring Models to Users, Denver, Colorado, November 4-9, 1990, Proceedings: American Water Resources Association, p. 1.

Stoner, J.D., 1991, National Water-Quality Assessment Program—Red River of the North: U.S. Geological Survey Open-File Report 91-151, 2 p.

Stoner, J.D., and Lorenz, D.L., 1992, Water quality assessment strategy for the Red River of the North Basin, North Dakota. South Dakota, and Minnesota [abs.]: North Dakota Water Quality Symposium, 1992, Bismarck, North Dakota, March 25-26, 1992, Proceedings: North Dakota State University Extension Service, p. 291.

1994, Environmental setting of the Red River of the North Basin, Minnesota, North Dakota, and South Dakota - Framework for a regional water quality assessment [abs.]: Minnesota Water '94-Managing Minnesota's Rivers and Watersheds, Minneapolis, Minnesota, April 21-22, 1994 [Proceedings], p. 2-3.

Stoner, J.D. Lorenz, D.L., Wiche, G.J., and Goldstein, R.M., 1993, Red River of the North Basin, Minnesota, North Dakota, and South Dakota: Water Resources Research Bulletin, v. 29, no. 4, p. 575-615.

Stoner, J.D., and Schoenberg, M.E., 1989, Preliminary evaluation of effects of ground-water withdrawals on Mississippi River flow near the Twin Cities metropolitan area, Minnesota [abs.]: Water Supply Issues in the Metropolitan Twin Cities area-Planning for the Future Droughts and Population Growth, St. Paul, Minnesota, October 25, 1988, Proceedings: Minnesota Water Resources Research, p. 5-6.

Sturrock, A.M., Rosenberry, D.O., Scarborough, J.L., and Winter, T.C., 1986, Climatic data for Williams Lake, Hubbard County, Minnesota, 1984: U.S. Geological Survey Open-File Report 86-64, 62 p.

Sturrock, A.M., Rosenberry, D.O., and Winter, T.C., 1987, Climatic data for Williams Lake, Hubbard County, Minnesota, 1985: U.S. Geological Survey Open-File Report 86-607, 40 p.

Taylor, W.W., LaBaugh, J.W., Freeberg, M.H., and Dowling, D.C., 1985, Fishery survey and related limnological conditions of Williams Lake, Hubbard County, Minnesota: U.S. Geological Survey Water-Resources Investigations Report 84-4145, 25 p.

Thomas, H.E., and Schneider, W.J., 1970, Water as an urban resource and nuisance: U.S. Geological Survey Circular 601-D, $9 \mathrm{p}$.

Thompsnn, G.L., 1949, Depositional patterns in sinuous melt-water channel deposits near Marshall, Lyon County, Minnesota and their hydrologic significance: Unpublished report on file with U.S. Geological Survey in Mounds View, Minnesota, $24 \mathrm{p}$.

Tornes, L.H., 1980, Preimpoundment water quality of the Wild Rice River, Norman County, Minnesota: U.S. Geological Survey Water-Resources Investigations Report 80-79, $36 \mathrm{p}$.

1981, Quality of surface water before implementation of a flood-control project in Chaska, Minnesota: U.S. Geological Survey Water-Resources Investigations Report 81-83, 53 p.

1985, Suspended sediment in Minnesota streams: U.S. Geological Survey Water-Resources Investigations Report 85-4312, $33 \mathrm{p}$.

-1989 . Effect of urban runoff on the water quality of lakes in Eagan, Minnesota: U.S. Geological Survey WaterResources Investigations Report 86-4331, 64 p. 
Tornes, L.H., and Brigham, M.E., 1994, Agricultural chemicals in streams of the Red River of the North drainage basin [abs.]: Minnesota Water '94 Managing Minnesota's Rivers and Watersheds, Minneapolis, Minnesota, April 21-22, 1994 [Proceedings], p. 3.

1994, Nutrients, suspended sediment, and pesticides in waters of the Red River of the North Basin. Minnesota, North Dakota, and South Dakota. 1970-90: U.S. Geological Survey Water-Resources Investigations Report 93$4231,62 \mathrm{p}$.

Tornes, L.H., and Have, M.R., 1980, Water quality of four lakes in Lakeville, Minnesota: U.S. Geological Survey Water-Resources Investigations Report 80-66, $51 \mathrm{p}$.

Tornes, L.H., Lorenz, D.L., Brigham, M.E., and Stoner, J.D., 1992, Plans for a water-quality assessment of the Red River of the North Basin, Minnesota, North Dakota, and South Dakota [abs.]: Minnesota Water '92Sustaining Water Resources in the '90s and Beyond, Minneapolis, Minnesota, Proceedings: University of Minnesota Water-Resources Research Center.

Trotta, L.C., 1988, Inventory of interbasin water transfer in Minnesota, in Symposium on Water Use Data for Water Resources Management. Bethesda, Maryland, August 1988, Proceedings: American Water Resources Association, p. 93-105.

1988, Inventory of interbasin water transfers in Minnesota: U.S. Geological Survey Open-File Report 88-466. $14 \mathrm{p}$.

1988, Water use for aquaculture in Minnesota, 1984: U.S. Geological Survey Water-Resources Investigations Report 88-4159, 6 p.

1990, Minnesota water supply and use, in Carr, J.E., Chase, E.B., Paulson, R.W., and Moody, D.W., compilers, National Water Summary 1987: U.S. Geological Survey Water-Supply Paper 2350, p. 313-320.

1991, Water use in Minnesota, 1985: State of Minnesota Department of Natural Resources Water Use Map Series, 1 sheet.

Trotta, L.C., and Horn, M.S., 1990, Importance of return flow as a component of water use: U.S. Geological Survey Open-File Report 90-179, 2 p.

U.S. Geological Survey, 1951, Surface-water supplies of the Mesabi Iron Range: Minnesota Department of Conservation, Division of Waters Bulletin 5, $117 \mathrm{p}$.

1957, Supplemental chemical analysis of surface waters in the Red River of the North Basin, North Dakota and Minnesota: Unpublished report on file with U.S. Geological Survey in Mounds View, Minnesota, $40 \mathrm{p}$.

1959, Chemical analysis of surface waters, Minnesota. October 1956 to September 1958:Unpublished report on file with U.S. Geological Survey in Mounds View, Minnesota, $16 \mathrm{p}$.

-1974, Status of projects in Minnesota, 1974-75 fiscal years: U.S. Geological Survey, 49 p.

- 1975, Status of projects in Minnesota, fiscal years 1975-76: U.S. Geological Survey, 55 p.

- 1976, Status of projects in Minnesota, fiscal years 1976 and 1977: U.S. Geological Survey, $36 \mathrm{p}$.

1977, Status of projects in Minnesota, fiscal years 1977 and 1978: U.S. Geological Survey, 59 p.

VanVoast, W.A., Broussard, W.L., and Wheat, D.E., 1972, Water resources of the Minnesota River-Hawk Creek watershed, southwestern Minnesota: U.S. Geological Survey Hydrologic Investigations Atlas HA-391, 3 sheets, scale $1: 250,000$.

VanVoast, W.A., Jerabek, L.A., and Novitzki, R.P., 1970, Water resources of the Redwood River watershed, southwestern Minnesota: U.S. Geological Survey Hydrologic Investigations Atlas HA-345, 3 sheets. 
VanVoast, W.A., and Novitzki, R.P., 1968, Ground-water flow related to streamflow and water quality: Water Resources Research, v. 4, no. 4, p. 769-775.

Warne, S.A., 1978. Map showing low-flow frequency of Minnesota streams: U.S. Geological Survey Open-File Report 78-132, 1 sheet.

Winter, T.C.. 1984, Reply to comment by M.P. Anderson, and J.A. Munter on. "the interaction of lakes with variably saturated porous media,": Water Resources Research, v. 20, no. 8. p. 1166.

Winter, T.C., Bidwell, L.E., and Maclay, R.W.. 1969, Water resources of the Otter Tail River watershed, westcentral Minnesota: U.S. Geological Survey Hydrologic Investigations Atlas HA-296, 4 sheets.

-1970, Water resources of the Wild Rice River watershed, northwestern Minnesota: U.S. Geological Survey Hydrologic Investigations Atlas HA-339, 4 sheets, scale 1:250,000.

Winter, T.C., Maclay, R.W., and Pike, G.M., 1967, Water resources of the Roseau River watershed, northwestern Minnesota: U.S. Geological Survey Hydrologic Investigations Atlas HA-241, 3 sheets, scale 1:250,000.

Winter, T.C., and Wright, H.E., Jr., 1977, Paleohydrologic phenomena recorded by lake sediments: EOS, Transactions, American Geophysical Union, v. 58, no. 4, p. 188-195.

Winterstein, T.A., 1982, Annotated report and data inventory for the Mississippi and Minnesota Rivers, MinneapolisSt. Paul metropolitan area: U.S. Geological Survey Open-File Report 82-869, 99 p.

- 1986, Water-resources activities of the U.S. Geological Survey in the Red River Valley, Minnesota fiscal year 1986: U.S. Geological Survey, 32 p.

Winterstein, T.A., and Arntson, A.D., 1989, Cost-effectiveness of the streamflow gaging program in Minnesota: U.S. Geological Survey Water-Resources Investigations Report 88-4129, 94 p.

Winterstein, T.A., Payne, G.A., Miller, R.A., and Stark, J.R., 1993, Selected basin characteristics and waterquality data for the Minnesota River Basin: U.S. Geological Survey Open-File Report 93-164, 100 p.

Wolf, R.J., 1981. Hydrogeology of the Buffalo aquifer, Clay and Wilkin Counties, west-central Minnesota: U.S. Geological Survey Water-Resources Investigations Report 81-4, 83 p. 


\section{Water Quality}

Adolphson, D.G., 1983, Availability and chemical quality of water from surficial aquifers in southwest Minnesota: U.S. Geological Survey Water-Resources Investigations Report 83-4030, 37 p.

Adolphson, D.G., and Jannis, J.A., 1978, Status of projects in Minnesota, fiscal year 1978: U.S. Geological Survey, $101 \mathrm{p}$.

Aiken, G.R., Capel, P.D., Furlong, E.T., Hult, M.F., and Thorn, K.A., 1991, Mechanisms controlling the transport of organic chemicals in subsurface environments, in Mallard, G.E., and Aronson, D.A., eds., U.S. Geological Survey Toxic Substances Hydrology Program-Proceedings of the technical meeting, Monterey, California, March 11-15, 1991: U.S. Geological Survey Water-Resources Investigations Report 91-4034, p. 633-637.

Albin, D.R., 1987, Minnesota ground-water quality: U.S. Geological Survey Open-File Report 87-733, 10 p.

Albin, D.R., and Breummen, L.B., 1987, Minnesota ground-water quality, in Moody, D.W., Carr, Jerry, Chase, E.B., and Paulson. R.W., compilers, National Water Summary 1986: U.S. Geological Survey Water-Supply Paper 2325, p. 313-320.

Alexander, E.C., Jr., Guo, Lifeng, Regan, C.P., and Landon, M.K., 1992, Geochemistry of ground water in an outwash aquifer under agricultural fields at the Management Systems Evaluation Area (MSEA) near Princeton, Minnesota [abs.]: EOS, Transactions, American Geophysical Union, v. 73, no. 43, p. 158.

Almendinger, J.E., 1991, Relation of nitrate concentrations in ground water to agricultural land use and soil type in Dakota County, Minnesota: U.S. Geological Survey Open-File Report 91-235, 2 p.

Amos, G.L., 1994, Water-resources activities of the U.S. Geological Survey Minnesota District, 1993 water year: U.S. Geological Survey Open-File Report 94-338, 72 p.

Amos, G.L., and Winterstein, T.A., 1993, Water-resources activities of the U.S. Geological Survey in Minnesota, 1991: U.S. Geological Survey Open-File Report 93-65, 73 p.

Anderson, H.W., Jr., 1985, Impact of agriculture on quality of water in surficial sand-plain aquifers in central Minnesota [abs.]: Annual Midwest Ground Water Conference, 30th, St. Paul, Minnesota, October 23-25, 1985 [Proceedings], p. 9.

1986, Hydrogeologic and water-quality characteristics of crystalline-rock aquifers of Archean and Proterozoic age, Minnesota: U.S. Geological Survey Water-Resources Investigations Report 86-4033, 3 sheets.

1989. Effects of agriculture on quality of water in surficial sand-plain aquifers in Douglas, Kandiyohi, Pope, and Stearns Counties, Minnesota: U.S. Geological Survey Water-Resources Investigations Report 87-4040, 52 p.

1993, Effects of agricultural and residential land use on ground-water quality, Anoka Sand Plain aquifer, eastcentral Minnesota: U.S. Geological Survey Water-Resources Investigations Report 93-4074, 62 p.

Anderson, H.W., Jr., Broussard, W.L., Farrell, D.F., and Felsheim, P.E., 1976, Water resources of the Rock River watershed, southwestern Minnesota: U.S. Geological Survey Hydrologic Investigations Atlas HA-555, 3 sheets, scale $1: 250,000$.

Anderson, H.W., Jr., Broussard, W.L., Farrell, D.F., and Hult, M.F., 1976, Water resources of the Des Moines River watershed, southwestern Minnesota: U.S. Geological Survey Hydrologic Investigations Atlas HA-553, 3 sheets, scales $1: 250,000$ and $1: 500,000$.

Anderson, J.L., Dowdy, R.H., Lamb, J.A., Delin, G.N., Knighton, Ray, Clay, David, and Lowery, Birl, 1993, Northern cornbelt sand plains Management Systems Evaluation Area, in Agricultural Research to Protect Water Quality, Minneapolis, Minnesota, February 21-24, 1993, Proceedings: Soil and Water Conservation Society, p. $39-47$. 
Anderson, H.W., Jr., Farrell, D.F., and Broussard, W.L., 1974, Water resources of the Blue Earth River watershed, south-central Minnesota: U.S. Geological Survey Hydrologic Investigations Atlas HA-525, 3 sheets, scale $1: 500,000$.

1974, Water resources of the lower Minnesota River watershed, south-central Minnesota: U.S. Geological Survey Hydrologic Investigations Atlas HA-526, 3 sheets, scale 1:500,000.

Anderson, H.W., Jr., Farrell, D.F., Broussard, W.L., and Felsheim, P.E., 1974, Water resources of the Cannon River watershed. southeastern Minnesota: U.S. Geological Survey Hydrologic Investigations Atlas HA-522, 3 sheets, scales $1: 250,000$ and $1: 500,000$.

Anderson, H.W., Jr., Farrell, D.F., Broussard, W.L., and Hult, M.F., 1975, Water resources of the Zumbro River watershed, southeastern Minnesota: U.S. Geological Survey Hydrologic Investigations Atlas HA-543, 3 sheets, scale $1: 250,000$.

Anderson, H.W., Jr., and Ruhl, J.F., 1984, Geohydrology and hydrochemistry of aquifers in Cretaceous rocks, Minnesota, in Geohydrology of the Dakota aquifer, C.V. Theis Conferences on Geohydrology, 1st, Lincoln, Nebraska, October 5-6, 1982, Proceedings: National Water Well Association, p. 27-37.

Anderson, H.W., Jr., and Stoner, J.D., 1989, Effects of controlled agricultural practices on water quality in a Minnesota sand-plain aquifer: U.S. Geological Survey Open-File Report 89-267, 2 p.

Anderson, J.L., Dowdy, R.H., and Delin, G.N., 1991, Ground water impacts from irrigated ridge tillage, in Irrigation and Drainage - 1991 National Conference, Honolulu, Hawaii, July 22-26, 1991, Proceedings: American Society of Civil Engineers, Irrigation and Drainage Division, p. 604-611.

Arntson, A.D., and Tornes, L.H., 1985, Rainfall-runoff relationship and water-quality assessment of Coon Creek watershed, Anoka County, Minnesota: U.S. Geological Survey Water-Resources Investigations Report 84-4013, $97 \mathrm{p}$.

Ayers, M.A., Brown, R.G., and Oberts, G.L., 1985, Runoff and chemical loading in small watersheds in the Twin Cities metropolitan area, Minnesota: U.S. Geological Survey Water-Resources Investigations Report 85-4122, $35 \mathrm{p}$.

Ayers, M.A., Payne, G.A., and Have, M.R., 1980, Effects of urbanization on the water quality of lakes in Eagan, Minnesota: U.S. Geological Survey Water-Resources Investigations Report 80-71, 42 p.

Ayers, M.A., Payne, G.A., and Oberts, G.L., 1980, Quality of runoff from small watersheds in the Twin Cities metropolitan area, Minnesota-A project plan: U.S. Geological Survey Open-File Report 80-592, 31 p.

Baedecker, M.J., Cozzarelli, I.M., Bennett, P.C., Eganhouse, R.P., and Hult, M.F., 1993, Evolution of the contaminant plume in an aquifer contaminated with crude oil, Bemidji, Minnesota [abs.], in Morganwalp, D.W., and Aronson, D.A., compilers, U.S. Geological Survey Toxic Substances Hydrology Program - Abstracts of the technical meeting, Colorado Springs, Colorado, September 20-24, 1993: U.S. Geological Survey Open-File Report 93-454, p. 103.

Baehr, A.L., and Hult, M.F., 1987, Mathematical modeling of hydrocarbon and oxygen transport coupled with microbial degradation in the unsaturated zone [abs.], in Franks, B.J., ed., U.S. Geological Survey program on toxic waste-ground-water contamination-Proceedings of the third technical meeting, Pensacola, Florida, March 23-27, 1987: U.S. Geological Survey Open-File Report 87-109, p. C-27-C28.

Bidwell, L.E., Winter, T.C., and Maclay, R.W. 1970, Water resources of the Red Lake River watershed, northwestern Minnesota: U.S. Geological Survey Hydrologic Investigations Atlas HA-346, 4 sheets, scales $1: 500,000$ and $1: 250,000$. 
Bohlke, J.K., Wanty, R.B., Tultle, M.L., Delin, G.N., and Landon, M.K., 1994, Resolving the effects of varying land use and aquifer reactions on nitrate contamination of ground water in central Minnesota [abs.]: EOS. Transactions, American Geophysical Union, v. 75, no. 19, p. 154.

Brigham, M.E., 1994. Pesticides detected in surface waters and fish of the Red River of the North drainage basin [abs.]: North Dakota Water-Quality Symposium, 4th biennial, Fargo, North Dakota, March 30-31, 1994. Proceedings: North Dakota State University Extension Service, p. 26.

1994, Pesticides detected in surface waters and fish of the Red River of the North drainage basin, in North Dakota Water-Quality Symposium, 4th biennial, Fargo, North Dakota, March 30-31, 1994, Proceedings: North Dakota State University Extension Service, p. 256-269.

Brigham, M.E., Tornes, L.H., and Lorenz, D.L., 1994, Load estimates for pesticides in the Red River of the North drainage basin [abs.]: American Geophysical Union 1994 Fall Meeting, San Francisco, California, December 59, 1994, Proceedings: American Geophysical Union, p. 230.

Broussard, W.L., Anderson, H.W., Jr., and Farrell, D.F., 1973, Water resources of the Cottonwood River watershed, southeastern Minnesota: U.S. Geological Survey Hydrologic Investigations Atlas HA-466. 3 sheets, scales, 1:253,400, 1:500,000, and 1:250,000.

Broussard, W.L., Farrell, D.F., Anderson, H.W., Jr., and Felsheim, P.E., 1975, Water resources of the Root River watershed, southeastern Minnesota: U.S. Geological Survey Hydrologic Investigations Atlas HA-548, 3 sheets, scale $1: 250,000$.

Brown, R.G., 1983, Atmospheric deposition of selected chemicals and their effect on nonpoint-source pollution in the Twin Cities metropolitan area, Minnesota: U.S. Geological Survey Water-Resources Investigations Report 83$4195,24 \mathrm{p}$.

1984, Effects of an urban wetland on sediment and nutrient loads in runoff: Wetlands, v. 4, p. 147-158.

1984, Relationship between quantity and quality of storm runoff and various watershed, characteristics in Minnesota, USA, in International Conference on Urban Storm Drainage, 3rd, Goteborg, Sweden, June 4-8, 1984 [Proceedings], p. 791-799.

1985, Effects of wetlands on quality of runoff entering lakes in the Twin Cities metropolitan area, Minnesota: U.S. Geological Survey Water-Resources Investigations Report 85-4170, 32 p.

1985, Errors associated with estimating ground-water flow and phosphorus flux components in hydrologic and phosphorous budgets of lakes [abs.]: Annual Midwest Ground Water Conference, 30th, St. Paul, Minnesota, October 23-25, 1985 [Proceedings], p. 3.

- 1986, Errors in estimating ground-water components of hydrologic and phosphorus budgets of lakes, in Subitzky, Seymour, ed., Selected papers in hydrologic sciences 1986: U.S. Geological Survey Water-Supply Paper 2310, p. 53-64.

Brown, R.G., and Stark, J.R., 1989, Hydrologic and water quality characteristics of a wetland receiving wastewater effluent in St. Joseph, Minnesota: Wetlands, v. 9, no. 2, p. 191-206.

Capel, P.D., 1990, Atmospheric deposition of herbicides in Minnesota [abs.]: Minnesota Water 1990 - Facing Environmental Challenges of the 1990's, St. Paul, Minnesota, April 1990, Proceedings: Minnesota Water Resources Research, p. 27.

1990, Atmospheric deposition of herbicides in the midcontinental United States [abs.]: EOS, Transactions, American Geophysical Union, v. 71, no. 43, p. 1329. 
1990, A bibliography of atrazine and its simple degradation products in the environment: U.S. Geological Survcy Open-File Report 89-613, 5 p.

1991. Wet atmospheric deposition of herbicides in Minnesota, in Mallard, G.E., and Aronson, D.A., eds., U.S. Gcological Survey Toxic Substances Hydrology Program - Proceedings of the technical meeting, Monterey, California, March 11-15, 1991: U.S. Geological Survey Water-Resources Investigations Report 91-4034, p. 334337.

Collier, C.R., 1974, An approximation of sediment yields from watersheds in Minnesota, in Winter Meeting, Chicago, Illinois, December 10-13, 1974, Proceedings: American Society of Agricultural Engineers, 9 p.

Cotter, R.D., and Bidwell, L.E., 1966, Water resources of the Pomme de Terre River watershed, west-central Minnesota: U.S. Geological Survey Hydrologic Investigations Atlas HA-220, 4 sheets, scale 1:250,000.

1968, Water resources of the Lac qui Parle River watershed, southwestern Minnesota: U.S. Geological Survey Hydrologic Investigations Atlas HA-269, 4 sheets, scale 1:250,000.

Cotter, R.D., Bidwell, L.E., Oakes, E.L., and Hollenstein, G.H., 1966, Water resources of the Big Stone Lake watershed, west-central Minnesota: U.S. Geological Survey Hydrologic Investigations Atlas HA-213, 4 sheets, scale $1: 250,000$.

Cotter, R.D., Bidwell, L.E., VanVoast, W.A., and Novitzki, R.P., 1968, Water resources of the Chippewa River watershed, west-central Minnesota: U.S. Geological Survey Hydrologic Investigations Atlas HA-286, 4 sheets, scale $1: 250,000$.

Cotter, R.D.,Young, H.L., Petri, L.R., and Prior, C.H., 1965, Ground and surface water in the Mesabi and Vermillion Iron Range area, northeastern Minnesota: U.S. Geological Survey Water-Supply Paper 1759-A, p. Al-A36.

1965, Water resources in the vicinity of municipalities on the central Mesabi Iron Range, northeastern Minnesota: U.S. Geological Survey Water-Supply Paper 1759-D, 20 p.

1965, Water resources in the vicinity of municipalities on the east-central Mesabi Iron Range, northeastern Minnesota: U.S. Gcological Survey Water-Supply Paper 1759-E, 23 p.

1965, Water resources in the vicinity of municipalities of the eastern Mesabi Iron Range, northeastern Minnesota: U.S. Geological Survey Water-Supply Paper 1759-F, 27 p.

1965, Water resources in the vicinity of municipalities on the west-central Mesabi Iron Range, northeastern Minnesota: U.S. Geological Survey Water-Supply Paper 1759-C, 21 p.

1965, Water resources in the vicinity of municipalities on the western Mesabi Iron Range, northeastern Minnesota: U.S. Geological Survey Water-Supply Paper 1759-B, 24 p.

Cowdery, T.K., 1994, Nutrient concentrations near the water table of the Sheyenne Delta aquifer beneath cropland areas-Preliminary results from a Red River of the North Basin land-use study [abs.], in Sorenson, S.K., ed., Proceedings Abstracts-American Water Resources Association's Symposium on the National Water-Quality Assessment (NAWQA) Program, Chicago, Illinois, November 7-9, 1994: U.S. Geological Survey Open-File Report 94-397, p. 7.

Cowdery, T.K., and Brigham, M.E., 1992, Baseflow dissolved-solids loads to streams of the Red River of the North Basin, South Dakota, North Dakota, and Minnesota [abs.]: Annual Midwest Ground-Water Conference, 37th, Souix Falls, South Dakota, October 14-16, 1992 [Proceedings], p. 38. 
Cowdery, T.K., and Goff, Karin, 1994, Nitrogen concentrations near the water table of the Sheyenne Delta aquifer beneath cropland areas, near Ransom and Richland Counties, North Dakota [abs.]: North Dakota Water-Quality Symposium, 4th biennial, Fargo, North Dakota, March 30-31, 1994, Proceedings: North Dakota State University Extension Service, p. 14.

1994, Nitrogen concentrations near the water table of the Sheyenne Delta aquifer beneath cropland areas, Ransom and Richland Counties, North Dakota, in North Dakota Water-Quality Symposium, 4th biennial, Fargo, North Dakota, March 30-31, 1994, Proceedings: North Dakota State University Extension Service, p. 89-102.

1994, Nutrient concentrations near the water table of the Sheyenne Delta aquifer beneath cropland areas, Ransom and Richland Counties, North Dakota [abs.]: Minnesota Water '94 Managing Minnesota's Rivers and Watersheds, Minneapolis, Minnesota, April 21-22, 1994 [Proceedings], p. 8-9.

Czarnecki, J.B., 1983, Fortran computer programs to plot and process aquifer pressure and temperature data: U.S. Geological Survey Water-Resources Investigations Report 83-4051, 50 p.

Delin, G.N., 1987, Ground-water quality in a complex system of glacial-drift aquifers in west-central Minnesota [abs.], in Zaporozec, A., ed., Annual Midwest Ground Water Conference, 32nd, Madison, Wisconsin, October 28-30, 1987 [Proceedings].

1990, Effects of differing agricultural practices on concentrations of nitrate and atrazine in a sand-plain aquifer, western Minnesota [abs.]: EOS, Transactions, American Geophysical Union, v. 71, no. 43, p. 1329.

1990, Geohydrology and water quality of confined-drift aquifers in the Brooten-Belgrade area, west-central Minnesota: U.S. Geological Survey Water-Resources Investigations Report 88-4124, 138 p.

Delin, G.N., Anderson, J.L., and Dowdy, R.H., 1992, The Minnesota Management Systems Evaluation Area Project-Assessing the effects of agricultural practices on ground-water quality [abs.]: Minnesota Water Conference, St. Paul, Minnesota, February 13-14, 1992 [Proceedings].

- 1992. The Minnesota Management Systems Evaluation Area Project-Assessing the effects of agricultural practices on ground-water quality [abs.]: Minnesota Water '92 - Sustaining Water Resources in the '90's and Beyond, Minneapolis, Minnesota, Proceedings: University of Minnesota Water-Resources Research Center.

Delin, G.N., and Landon, M.K., 1993, Effects of focused recharge on the transport of agricultural chemicals at the Princeton, Minnesota, Management Systems Evaluation Area, 1991-92 [abs.]: Agricultural Research to Protect Water Quality, Minneapolis, Minnesota, February 21-24, 1993, Proceedings: Soil and Water Conservation Society, p. 210-214.

- 1993, Effects of focused recharge on the transport of agricultural chemicals at the Princeton, Minnesota Management Systems Evaluation Area, 1991-92: U.S. Geological Survey Open-File Report 93-42, 8 p.

1993. Effects of focused recharge on transport of agricultural chemicals at the Princeton, Minnesota Management Systems Evaluation Area, 1991-1992: U.S. Geological Survey Open-File Report 93-79, 2 p.

- 1993. Effects of topography on the transport of agricultural chemicals near Princeton, Minnesota, 1992 [abs.], in Morganwalp, D.W., and Aronson, D.A., compilers, U.S. Geological Survey Toxic Substances Hydrology Program-Abstracts of the technical meeting, Colorado Springs, Colorado, September 20-24, 1993: U.S. Geological Survey Open-File Report 93-454, p. 91.

1994, Effects of focused recharge on the transport of agricultural chemicals near Princeton, Minnesota, 1992 [abs.]: Minnesota Water '94-Managing Minnesota's Rivers and Watersheds, Minneapolis, Minnesota, April 2I-22, 1994 [Proceedings], p. 9.

Delin, G.N., Landon, M.K., Anderson, J.L., and Dowdy, R.H., 1992, Hydrologic research at the Princeton, Minnesota Management Systems Evaluation Area: U.S. Geological Survey Open-File Report 92-107, 2 p. 
1992, The Minnesota Management Systems Evaluation Area [abs.]: Agronomy Abstracts of 1992 Annual Mecting, Minneapolis, Minnesota, November 1-6, 1992, Proceedings: American Society of Agronomy, p. 322.

Delin, G.N., Landon, M.K., Healy, R.W., and Olsen, H.W., 1992, Preferential flow through the unsaturated zone beneath a corn field near Princeton, Minnesota [abs.]: Joint Spring Meeting of American Geophysical Union, Canadian Geophysical Union, and Mineralogical Society of America, Montreal, Canada, May 12-15, 1992, Proceedings: American Geophysical Union, p. 132.

Delin, G.N., Landon, M.K., Lamb, J.A., and Anderson, J.L., 1994, Characterization of the hydrogeology and water quality at the Management Systems Evaluation Area near Princeton, Minnesota, 1991-92: U.S. Geological Survey Water-Resources Investigations Report 94-4149, $54 \mathrm{p}$.

1994, Hydrogeologic and water-quality data used to characterize the Management Systems Evaluation Area near Princeton, Minnesota, 1991: U.S. Geological Survey Open-File Report 94-337, 42 p.

Diedrich, M.M., and Jannis, J.A., 1980, Status of projects in Minnesota, fiscal year 1980: U.S. Geological Survey, $99 \mathrm{p}$.

1981, Status of projects in Minnesota, fiscal year 1981: U.S. Geological Survey, $58 \mathrm{p}$.

Ehrlich, G.G., Georlitz, D.F., Godsy, E.M., and Hult, M.F., 1982, Degradation of phenolic contaminants in ground water by anaerobic bacteria-St. Louis Park, Minnesota: Ground Water, v. 20, no. 6, p. 703-710.

Ericson, D.W., Lindholm, G.F., and Helgesen, J.O., 1974, Water resources of the Rum River watershed, eastcentral Minnesota: U.S. Geological Survey Hydrologic Investigations Atlas HA-509, 3 sheets, scales 1:250,000 and $1: 500,000$.

1976, Water resources of the Rainey Lake watershed, northeastern Minnesota: U.S. Geological Survey Hydrologic Investigations Atlas HA-556, 2 sheets, scale 1:1,000,000.

Farrell, D.F., Broussard, W.L., Anderson, H.W., Jr., and Hult, M.F., 1975, Water resources of the Cedar River watershed, southeastern Minnesota: U.S. Geological Survey Hydrologic Investigations Atlas HA-552, 3 sheets, scale $1: 250,000$.

Feth, J.H., 1965, Preliminary map of the conterminous United States showing depth to and quality of shallowest ground water containing more than 1,000 parts per million dissolved solids: U.S. Geological Survey Hydrologic Investigations Atlas HA-199, 31 p., 2 sheets, scale 1:3,168,000.

Giacomini, E.G., Wolf, R.J., Payne, G.A., and Adolphson, D.G., 1980, Hydrologic characteristics of Elim, Skunk, and Deer Creeks, Upper Nemadji River Basin, Minnesota: U.S. Geological Survey Open-File Report 80-47, 65 p.

Groschen, G.E., and Alexander, E.C., Jr., 1981, Geochemistry of Williams Lake, Hubbard County, Minnesota [abs.]: EOS, Transactions, American Geophysical Union, v. 63, no. 33, p. 613.

1982, Geochemistry of Williams Lake, Hubbard County, Minnesota [abs.]: EOS, Transactions, American Geophysical Union, v. 63, no. 33.

Guo, Lifeng, Alexander, E.C., Jr., Landon, M.K., Delin, G.N., and Regan, C.P., 1994, Geochemical characteristics and transport of agricultural leachates in a surficial sand and gravel aquifer near Princeton, Minnesota, 1991-92 [abs.]: 1993 Fall Meeting, San Francisco, California, December 6-10, 1993, Proceedings: American Geophysical Union, p. 269.

Guswa, J.H., Siegel, D.I., and Gillies, D.C., 1982, Preliminary evaluation of the ground-water-flow system in the Twin Cities metropolitan area, Minnesota: U.S. Geological Survey Water-Resources Investigations Report 82$44,65 \mathrm{p}$.

Guy, H.P., 1970, Sediment problems in urban areas: U.S. Geological Survey Circular 601-E, 8 p. 
Hatfield, J.L., Anderson, J.L., Alberts, E.E., Prato, Tony, Watts, D.G., Ward, Andrew, Delin, G.N., and Swank, Robert, 1993, Management Systems Evaluation Areas-An overview: Agricultural research to protect water quality, Minneapolis, Minnesota, February 21-24, 1993. Proceedings: Soil and Water Conservation Society, p. $1-10$.

Have, M.R., 1975, A water-quality assessment of the Burham Creek watershed, Polk County, Minnesota: U.S. Geological Survey Open-File Report 75-647, 15 p.

1975, Some limnological aspects of 20 selected lakes in Eagan and Apple Valley, Minnesota: U.S. Geological Survey Open-File Report 75-528, 44 p.

1980, Water quality of Rogers Lake, Dakota County, Minnesota: U.S. Geological Survey Water-Resources Investigations Report 80-5, $35 \mathrm{p}$.

1991, Selected water-quality characteristics in the Upper Mississippi River Basin, Royalton to Hastings, Minnesota: U.S. Geological Survey Water-Resources Investigations Report 88-4053, 152 p.

Have, M.R., Payne, G.A., and Ayers, M.A., 1981, Water quality of Alimagnet, Farquar, and Long Lakes in Apple Valley, Minnesota: U.S. Geological Survey Water-Resources Investigations Report 81-40, 38 p.

Have, M.R., and Tornes, L.H., 1987, Water quality data for Orwell Reservoir and Otter Tail River near Fergus Falls, Minnesota: U.S. Geological Survey Open-File Report 87-537, 48 p.

Hein, M.D., 1982, Status of water-resources projects in Minnesota fiscal year 1982: U.S. Geological Survey, 61 p.

Helgesen, J.O., 197I, Appraisal of ground water for irrigation in the Little Falls area, Morrison County, Minnesota: U.S. Geological Survey Open-File Report, 54 p.

-1973, Appraisal of ground water for irrigation in the Little Falls area, Morrison County, Minnesota: U.S. Geological Survey Water-Supply Paper 2009-D, 40 p.

1977, Ground-water appraisal of the Pineland Sands area, central Minnesota: U.S. Geological Survey WaterResources Investigations Report 77-102, 49 p.

Helgesen J.O., Ericson, D.W., and Lindholm, G.F., 1975, Water resources of the Mississippi and Sauk Rivers watershed, central Minnesota: U.S. Geological Survey Hydrologic Investigations Atlas HA-534, 3 sheets, scale $1: 250,000$.

Helgesen J.O., and Lindholm, G.F., 1973, Geology and water-supply potential of the Anoka Sand Plain aquifer, Minnesota: U.S. Geological Survey Open-File Report, 19 p.

Helgesen J.O., Lindholm, G.F., Broussard, W.L., and Ericson, D.W., 1973, Water resources of the Kettle River watershed, east-central Minnesota: U.S. Geological Survey Hydrologic Investigations Atlas HA-437, 4 sheets, scale $1: 250,000$.

Helgesen J.O., Lindholm, G.F., and Ericson, D.W., 1975, Water resources of the Lake of the Woods watershed, north-central Minnesota: U.S. Geological Survey Hydrologic Investigations Atlas HA-544, 2 sheets, scale 1:500,000.

- 1976, Water resources of the Little Rock River watershed, northeastern Minnesota: U.S. Geological Survey Hydrologic Investigations Atlas HA-551, 2 sheets, scale 1:500,000.

Hult, M.F., 1984, Assessment of ground-water contamination by coal-tar derivatives, St. Louis Park area Minnesota: U.S. Geological Survey Open-File Report 84-867, 57 p. 
1984, Ground-water contamination by crude oil at the Bemidji, Minnesota research site - an introduction, in Hult, M.F., ed., Ground-water contamination by crude oil at the Bemidji, Minnesota research site-U.S.S. Geological Survey toxic waste ground-water contamination study: U.S. Geological Survey Water-Resources Investigations Report 84-4188, p. 1-15.

1987, Movement and fate of crude-oil in contaminants in the subsurface environment at Bemidji, Minnesota, Chapter C. in Frank, B.J., ed., U.S. Geological Survey program on toxic waste-ground-water contaminationProceedings of the third technical meeting, Pensacola, Florida, March 23-27, 1987: U.S. Geological Survey Open-File Report 87-109, p. C3-C4.

1989, Subsurface contamination at the Bemidji, Minnesota research site [abs.], in Mallard. G.E., and Ragone, S.E., cds., U.S. Geological Survey Toxic Substances Hydrology Program-Proceedings of the technical meeting, Phoenix, Arizona. September 26-30, 1988: U.S. Geological Survey Water-Resources Investigations Report 88-4220, p. 3.

1991. Overview of research on contamination of the subsurface by crude oil at the Bemidji. Minnesota toxic substances research site, in Mallard, G.E., and Aronson, D.A., eds., U.S. Geological Survey Toxic Substances Hydrology Program_-Proceedings of technical meeting, Monterey, California, March 11-15, 1991: U.S. Geological Survey Water-Resources Investigations Report 91-4034, p. 611-613.

Hult, M.F.. ed., 1984, Ground-water contamination by crude oil at the Bemidji, Minnesota research site-U.S. Geological Survey toxic waste-ground-water contamination study: U.S. Geological Survey Water-Resources Investigations Report 84-4188, $107 \mathrm{p}$.

Hult, M.F., Chang, F.H., and Pfannnkuch, H.O., 1986, Microbial oxidation of petroleum vapors in the unsaturated zone, in Chapman Conference on Microbial Processes in the Transport. Fate and In-situ Treatment of Subsurface Contaminants, Snowbird, Utah, October 1-3, 1986: American Geophysical Union Chapman Meeting Abstracts, p. 23-24.

Hult, M.F., and Grabbe, R.R., 1988, Distribution of gases and hydrocarbon vapors in the unsaturated zone, in Ragone. S.E., ed., U.S. Geological Survey program on toxic waste-ground water contamination-Proceedings of the second technical meeting, Cape Cod. Massachusetts, October 21-25, 1985: U.S. Geological Survey OpenFile Report 86-481, p. C21-C25.

Hult, M.F., Landon, M.K., and Pfannkuch, H.O., 1991, Field validation of conceptual models of mobilization and transport of volatile petroleum derivatives in the unsaturated zone near Bemidji, Minnesota, in Mallard, G.E., and Aronson, D.A., eds., U.S. Geological Survey Toxic Substances Hydrology Program-Proceedings of technical meeting, Monterey, California, March 11-15, 199I: U.S. Geological Survey Water-Resources Investigations Report 9I-4034, p. 62 I-626.

Hult, M.F., and Schoenberg, M.E., 1981, Preliminary evaluation of ground-water contamination by coal-tar derivatives, St. Louis Park area, Minnesota: U.S. Geological Survey Water-Resources Investigations Report 81 $72.53 \mathrm{p}$.

1984, Preliminary evaluation of ground-water contamination by coal-tar derivatives, St. Louis Park area, Minnesota: U.S. Geological Survey Water-Supply Paper 2211, 53 p.

Jannis, J.A., 1983, Status of water-resources projects in Minnesota, fiscal year 1983: U.S. Geological Survey, 74 p.

1984, Status of projects in Minnesota, fiscal year 1984: U.S. Geological Survey Open-File Report, 84 p.

1986, Water-resources activities of the U.S. Geological Survey in Minnesota, fiscal year 1985: U.S. Geological Survey Open-File Report 86-133, 83 p.

Jannis, J.A., and Diedrich, M.M., 1979, Status of projects in Minnesota, fiscal year 1979: U.S. Geological Survey, $79 \mathrm{p}$. 
Komor, S.C., 1992, Bidirectional sulfate diffusion in saline-lake sediments--Evidence from Devil's Lake: Geology, v. 20, no. 4 , p. $319-322$.

1992, Nitrate in Minnesota sand-plain aquifers [abs.]: Joint Spring Meeting of American Geophysical Union, Canadian Geophysical Union, and Mineralogical Society of America, Montreal, Canada, May 12-15, 1992, Proceedings: American Geophysical Union, p. 125.

1993, Stable isotopes used to evaluate soil-water movements [abs.]: American Geophysical Union Spring Meeting, Baltimore, Maryland, May 24-28, 1993, Proceedings: American Geophysical Union, p. 140.

1994, Bottom-sediment chemistry in Devil's Lake, northeast North Dakota: Sedimentology and Geochemistry of Modern and Ancient Saline Lakes, no. 50, p. 21-32.

- 1994, Geochemistry and hydrology of a calcareous fen within the Savage Fen wetlands complex, Minnesota, USA: Geochimica et Cosmochimica Acta, v. 58, no. 16, p. 3353-3367.

1994, Geochemistry and hydrology of Savage Fen, a calcareous fen in the Minnesota River Valley [abs]: Minnesota Water '94-Managing Minnesota's Rivers and Watersheds, Minneapolis, Minnesota, April 21-22, 1994 [Proceedings], p. 9.

Komor, S.C., and Anderson, H.W., Jr., 1993, Nitrogen isotopes as indicators of nitrate sources in Minnesota sandplain aquifers: Ground Water, v. 31, no. 2, p. 260-270.

Komor, S.C., and Emerson, D.G., 1992, Atrazine and bromide movement through the unsaturated sand plains at sites in Minnesota and North Dakota [abs.]: 1992 North Dakota Water Quality Symposium, Bismarck, North Dakota, March 25-26, 1992, Proceedings: North Dakota State University Extension Service.

- 1994, Movements of water, solutes, and stable isotopes in the unsaturated zones of two sand plains in the Upper Midwest: Water Resources Research, v. 30, no. 2, p. 253-267.

LaBaugh, J.W., Groschen, G.E., and Winter, T.C., 1981, Limnological and geochemical survey of Williams Lake, Hubbard County, Minnesota: U.S. Geological Survey Water-Resources Investigations Report 81-41, 38 p.

Lamb, J.A., Anderson, J.L.. Dowdy, R.H., and Delin, G.N., 1992, Northern cornbelt sandplain MSEA [abs.]: Minnesota Water '92 - Sustaining Water Resources in the '90's and Beyond, Minneapolis, Minnesota, Proceedings: University of Minnesota Water-Resources Research Center.

Landon, M.K., Delin, G.N., Guo, Lifeng, Regan, C.P., Anderson, J.L., and Dowdy, R.H., 1992, Ground-water quality at the Management Systems Evaluation Area near Princeton, Minnesota, 1991 [abs.]: Annual Midwest Ground Water Conference, 37th, Souix Falls, South Dakota, October 14-16, 1992 [Proceedings], p. 30.

Landon, M.K., Delin, G.N., Guo, Lifeng, Regan, C.P., Lamb, J.A., Dowdy, R.H., and Anderson, J.L., 1993, Occurrence of agricultural chemicals in ground water at the Princeton, Minnesota Management Systems Evaluation Area: Agricultural Research to Protect Water Quality, Minneapolis, Minnesota, February 21-24, 1993. Proceedings: Soil and Water Conservation Society, p. 434-438.

Landon, M.K., Delin, G.N., Lamb, J.A., Anderson, J.L., and Dowdy, R.H., 1994, Impacts of farming systems on ground-water quality at the Princeton, Minnesota, Management Systems Evaluation Area (MSEA) 1991-1992 [abs.]: Minnesota Water '94 Managing Minnesota's Rivers and Watersheds, Minneapolis, Minnesota April 2122, 1994 [Proceedings], p. 6.

Landon, M.K., Delin, G.N., Lamb, J.A., Dowdy, R.H., and Anderson, J.L., 1993, Effects of farming systems on ground water quality at the Princeton, Minnesota Management Systems Evaluation Area, 1991 [abs.], in Morganwalp, D.W., and Aronson, D.A., compilers, U.S. Geological Toxic Substances Hydrology ProgramAbstracts of the technical meeting, Colorado Springs, Colorado: U.S. Geological Survey Open-File Report 93454, p. 63. 
1994, Effects of farming systems on concentrations of nitrate in ground water at the Princeton, Minnesota Management Systems Evaluation Area (MSEA), 1991-1992 [abs.]: EOS, Transactions, American Geophysical Union, v. 75 , no. 19 , p. 157.

Landon, M.K., Delin, G.N., Lamb, J.A., and Guo, Lifeng, 1993, Ground-water quality at the Management Systems Evaluation Area (MSEA) near Princeton, Minnesota, 1991: U.S. Geological Survey Open-File Report 93-43, 8 p.

1993, Ground-water quality at the Management Systems Evaluation Area near Princeton, Minnesota, 1991: U.S. Geological Survey Open-File Report 93-80, 2 p.

Landon, M.K., and Hult, M.F., 1991, Evolution of physical properties and composition of a crude oil spill, in Mallard, G.E., and Aronson, D.A., eds., U.S. Geological Survey Toxic Substances Hydrology ProgramProceedings of the technical meeting, Monterey, California, March 11-15, 1991: U.S. Geological Survey WaterResources Investigations Report 91-4034, p. 641-645.

1993, Source mass balance calculated from changes on composition of spilled crude oil in the subsurface near Bemidji, Minnesota [abs.], in Morganwalp, D.W., and Aronson, D.A., compilers, U.S. Geological Survey Toxic Substances Hydrology Program-Abstracts of the technical meeting, Colorado Springs, Colorado, September 20-24, 1993: U.S. Geological Survey Open-File Report 93-454, p. 105.

Landon, M.K., and Hult, M.F., 1992, Source mass balance calculated from changes in physical properties and composition of spilled crude oil in the subsurface near Bemidji, Minnesota: EOS, Transactions, American Geophysical Union, v. 73, no. 14, p. 132-133.

Langford, R.H., 1964, Chemical quality of the water resources Kittson, Marshall, and Roseau Counties, Minnesota: Unpublished report on file with U.S. Geological Survey in Mounds View, Minnesota, 168 p.

Larson, S.P., Mann, W.B., IV, Steele, T.D., and Susag, R.H., 1974, Time-trend and river-reach assessments in water quality of the Mississippi River, Minneapolis-St. Paul, metropolitan area, Minnesota [abs.]: EOS, Transactions, American Geophysical Union, v. 55, no. 12, p. 1114.

1976, Graphic and analytical methods for assessments of stream-water quality-Mississippi River in the Minneapolis-St. Paul metropolitan area, Minnesota: U.S. Geological Survey Water-Resources Investigations Report 76-94, $55 \mathrm{p}$.

Lindholm, G.F., 1970, An appraisal of ground water for irrigation in the Wadena area, central Minnesota: U.S. Geological Survey Water-Supply Paper 1983, 56 p.

1980, Ground-water appraisal of sand plains in Benton, Sherburne, Stearns, and Wright Counties, central Minnesota: U.S. Geological Survey Water-Resources Investigations Report 80-1285, 103 p.

Lindholm, G.F., Ericson, D.W., Broussard, W.L., and Hult, M.F., 1979, Water resources of the St. Louis River watershed, northeastern Minnesota: U.S. Geological Survey Hydrologic Investigations Atlas HA-586, 3 sheets.

Lindholm, G.F., Farrell, D.F., and Helgesen, J.O., 1974, Water resources of the Crow River watershed. southcentral Minnesota: U.S. Geological Survey Hydrologic Investigations Atlas HA-528, 3 sheets, scale 1:500,000.

Lindholm, G.F., Helgesen, J.O., Broussard, W.L., and Farrell, D.F., 1974, Water resources of the lower St. Croix River watershed, east-central Minnesota: U.S. Geological Survey Hydrologic Investigations Atlas HA-490, 3 sheets, scales $1: 250,000$ and $1: 500,000$.

1974, Water resources of the Snake River watershed. east-central Minnesota: U.S. Geological Survey Hydrologic Investigations Atlas HA-488, 3 sheets, scales 1:250,000 and 1:500,000.

Lindholm, G.F., Helgesen, J.O., and Ericson, D.W., 1976, Water resources of the Fork River watershed, northcentral Minnesota: U.S. Geological Survey Hydrologic Investigations Atlas HA-549, 2 sheets, scale 1:500,000. 
Lindholm, G.F., and Norvitch, R.F., 1976, Ground water in Minnesota: U.S. Geological Survey Open-File Report 76-354, $100 \mathrm{p}$.

Lindholm, G.F., Oakes, E.L., Ericson, D.W., and Helgesen, J.O., 1972, Water resources of the Crow Wing River watershed, central Minnesota: U.S. Geological Survey Hydrologic Investigations Atlas HA-380, 4 sheets, scale $1: 250,000$.

Lorenz, D.L., and Stark, J.R., 1987, Evaluation of gradient-control options for contaminated ground water in the St. Peter aquifer, St. Louis Park, Minnesota [abs.], in Zaporozec, A., ed., Annual Midwest Ground Water Conference, 32nd, Madison, Wisconsin, October 28-30, 1987 [Proceedings].

Maclay, R.W., Bidwell, L.E., and Winter, T.C., 1969, Water resources of the Buffalo River watershed, west-central Minnesota: U.S. Geological Survey Hydrologic Investigations Atlas HA-307, 3 sheets, scale 1:250,000.

Maclay, R.W., and Winter, T.C., 1967, Geochemistry and ground-water movement in northwestern Minnesota: Ground Water, v. 5, no. 1, p. 11-19.

Maclay, R.W., Winter, T.C., and Bidwell, L.E., 1968, Water resources of the Mustinka and Bois de Sioux Rivers watershed, west-central Minnesota: U.S. Geological Survey Hydrologic Investigations Atlas HA-272, 4 sheets, scale $1: 250,000$.

- 1972, Water resources of the Red River of the North drainage basin in Minnesota: U.S. Geological Survey Water-Resources Investigations Report 1-72, $129 \mathrm{p}$.

Maclay, R.W., Winter, T.C., and Pike, G.M., 1965, Water resources of the Middle River watershed, northwestern Minnesota: U.S. Geological Survey Hydrologic Investigations Atlas HA-201, 3 sheets, scale 1:250,000.

Maclay, R.W., Winter, T.C., and Pike, G.M., 1967, Water resources of the Two Rivers watershed, northwestern Minnesota: U.S. Geological Survey Hydrologic Investigations Atlas HA-237, 4 sheets, scale 1:250,000.

Maderak, M.L., 1963, Quality of waters, Minnesota A compilation. 1955-62: Minnesota Department of Conservation, Division of Waters Bulletin 21, $104 \mathrm{p}$.

1964, Relation of chemical quality of water to recharge to the Jordan Sandstone in the Minneapolis-St. Paul area, Minnesota: U.S. Geological Survey Professional Paper 50I-C, p. CI76-CI79.

-1965, Chemical quality of ground water in the Minneapolis-St. Paul area, Minnesota: Minnesota Department of Conservation, Division of Waters Bulletin 23, $44 \mathrm{p}$.

Miller, R.T., 1981, Hydrologic data for the Pelican River Sand-Plain aquifer, western Minnesota: U.S. Geological Survey Open-File Report 80-695, 86 p.

1982, Appraisal of the Pelican River Sand-Plain aquifer, western Minnesota: U.S. Geological Survey OpenFile Report 82-347, 44 p.

1987, Effects of local hydraulic discontinuities on the transport of crude oil residuals in ground water, Bemidji, Minnesota, in Franks, B.J., ed., U.S. Geological Survey program on toxic waste-ground water contaminationProceedings of the third technical meeting, Pensacola, Florida, March 23-27, 1987: U.S. Geological Survey Open-File Report 87-109, p. C9.

Mitton, G.B., 1991, Water quality data for Sauk Lake and tributaries near Sauk Center, Minnesota, 1988-89: U.S. Geological Survey Open-File Report 91-456, 57 p.

Moyle, J.B., 1956, Relationships between the chemistry of Minnesota surface waters and wildlife management: Journal of Wildlife Management, v. 20, no. 3, p. 303-320. 
Myette, C.F., 1982, Baseline water-quality data for sand-plain aquifers in Hubbard. Morrison. Otter Tail, and Wadena Counties. Minnesota: U.S. Geological Survey Open-File Report 82-909, 112 p.

1984, Appraisal of water from surficial-outwash aquifers in Todd County and parts of Cass and Morrison Counties, central Minnesota: U.S. Geological Survey Water-Resources Investigations Report 83-4156, 43 p.

1984, Ground-water-quality appraisal of sand-plain aquifers in Hubbard, Morrison. Otter Tail. and Wadena Counties, Minnesota: U.S. Geological Survey Water-Resources Investigations Report 84-4080, 49 p.

1985, Hydrogeology of sand-plain aquifers in Carlton, Kanabec, and Pine Counties, east-central Minnesota: U.S. Geological Survey Water-Resources Investigations Report 85-4334, 66 p.

1991, Hydrology, water quality, and simulation of ground-water flow at a taconite tailings basin near Kecwatin, Minnesota: U.S. Geological Survey Water-Resources Investigations Report 88-4230, $61 \mathrm{p}$.

Nelson, Luanne, and Brown, R.G., 1983, Streamflow and water-quality data for wetland inflows and outflows in the Twin Cities metropolitan area, Minnesota, 1981-82: U.S. Geological Survey Open-File Report 83-543, 182 p.

Norvitch, R.F., Ross, T.G., and Brietkrietz, Alex, 1973, Water resources outlook for the Minneapolis-St. Paul metropolitan area, Minnesota: U.S. Geological Survey Open-File Report 73-203, 219 p.

Novitzki, R.P., VanVoast, W.A., and Jerabek, L.A., 1969, Water resources of the Yellow Medicine River watershed, southwestern Minnesota: U.S. Geological Survey Hydrologic Investigations Atlas HA-320, 3 sheets, scale $1: 250,000$.

Oakes, E.L., 1970, Geology and ground-water resources of the Grand Rapids area, north-central Minnesota: U.S. Geological Survey Hydrologic Investigations Atlas HA-322, 2 sheets, scale 1:48,000.

Oakes, E.L., and Bidwell, L.E., 1968, Water resources of the Mississippi headwaters watershed, north-central Minnesota: U.S. Geological Survey Hydrologic Investigations Atlas HA-278, 4 shects, scale 1:250,000.

Olcott, P.G., Ericson, D.W., Felsheim, P.E., and Broussard, W.L., 1978, Water resources of the Lake Superior watershed, northeastern: U.S. Geological Survey Hydrologic Investigations Atlas HA-582, 2 sheets, scales $1: 500,000$ and $1: 1,000,000$.

Payne, G.A., 1977, Baseline water quality of Long Meadow Lake, Ponds AP-9 and AP-1 0 and Black Dog Creek, Hennepin and Dakota Counties, Minnesota: U.S. Geological Survey Open-File Report 77-424. 56 p.

1979, Water-quality reconnaissance of lakes in Voyageurs National Park, Minnesota: U.S. Geological Survey Open-File Report 79-556, $40 \mathrm{p}$.

1980, Baseline water quality of Schmidt, Hornbeam, and Horseshoe Lakes, Dakota County, Minnesota: U.S. Geological Survey Water-Resources Investigations Report 80-3, 38 p.

- 1983, Streamflow and suspended-sediment transport in Garvin Brook, Winona County, southeastern Minnesota-Hydrologic data for 1982: U.S. Geological Survey Open-File Report 83-212, 22 p.

- 1991, Sediment, nutrients, and oxygen demanding substances in the Minnesota River-Selected water-quality data, 1989-90: U.S. Geological Survey Open-File Report 91-498, 37 p.

1991, Water quality of lakes and streams in Voyageurs National Park, Minnesota, 1977-84: U.S. Geological Survey Water-Resources Investigations Report 88-4016, 95 p.

1994, Ground-water base flow to the Upper Mississippi River upstream of the Minneapolis-St. Paul area, Minnesota during July 1988, in Water Available from the Mississippi River at Minneapolis and Other Upstream Minnesota Locations During Low-Flow Conditions: U.S. Army Corps of Engineers, p. C1-C36. 
1994, Sources and transport of sediment, nutrients, and oxygen-demanding substances in the Minnesota River Basin, 1989-92: U.S. Geological Survey Water-Resources Investigations Report 93-4232, 71 p.

Payne, G.A., Ayers, M.A., and Brown, R.G., 1982, Quality of runoff from small watersheds in the Twin Cities metropolitan area, Minnesota-Hydrologic data for 1980: U.S. Geological Survey Open-File Report 82-504, $289 \mathrm{p}$.

Pereira, W.E., Rostad, C.E., Garbarino, J.R., and Hult, M.F., 1983, Ground-water contamination by organic bases derived from coal-tar wastes: Environmental Toxicology and Chemistry, v. 2, p. 283-294.

Pfannkuch, H.O., Nourse, S.M., and Hult, M.F., 1988, Mass transfer at the alkane water interface in laboratory columns of porous media, in Ragone, S.E., ed., U.S. Geological Survey program on toxic waste - ground water contamination-Proceedings of the second technical meeting, Cape Cod, Massachusetts, October 21-25, 1985: U.S. Geological Survey Open-File Report 86-481, p. C29-C32.

Piatt, J.J., Eisenreich, S.J., Barkhus, D.A., and Capel, P.D., 1993, Sorption of polycyclic aromatic hydrocarbons to aquifer materials containing low-organic carbon content from Bemidji, Minnesota [abs.], in Morganwalp, D.W., and Aronson, D.A., compilers, U.S. Geological Survey Toxic Substances Hydrology Program-Abstracts of the technical meeting, Colorado Springs, Colorado, September 20-24, 1993: U.S. Geological Survey OpenFile Report 93-454, p. 129.

Reeder, H.O., 1969, Ground water for irrigation in the Perham area, Otter Tail County, west-central Minnesota: U.S. Geological Survey Open-File Report, 56 p.

1972, Availability of ground water for irrigation from glacial outwash in the Perham area, Otter Tail County, Minnesota: U.S. Geological Survey Water-Supply Paper 2003, 45 p.

1978, Summary appraisals of the Nation's ground-water resources—Souris-Red-Rainey Region: U.S. Geological Survey Professional Paper 813-K, 25 p.

Reeder, H.O., and Norvitch, R.F., 1974, Hydrogeologic reconnaissance of ground-water pollution in the Pine Bend area, Dakota County, Minnesota: U.S. Geological Survey Open-File Report, 27 p.

Revesz, Kinga, Copen, Tyler, Baedecker, M.J., and Hult, M.F., 1993, Use of carbon and hydrogen stable isotopes to investigate the production and fate of methane at a toxic waste site, Bemidji, Minnesota [abs.], in Morganwalp, D.W., and Aronson, D.A., compilers, U.S. Geological Survey Toxic Substances Hydrology Program-Abstracts of the technical meeting, Colorado Springs, Colorado, September 20-24, 1993: U.S. Geological Survey OpenFile Report 93-454, p. 128.

Rodis, H.G., and Schneider, Robert, 1960, Occurrence of ground waters of low hardness and of high chloride content in Lyon County, Minnesota: U.S. Geological Survey Circular 423, 3 p.

Rostad, C.E., Pereira, W.E., and Hult, M.F., 1985, Partitioning studies of coal-tar constituents in a two-phase contaminated ground-water system: Chemosphere, v. 14, no. 8, p. 1023-1036.

Ruh1, J.F., 1987, Hydrogeologic and water-quality characteristics of glacial-drift aquifers in Minnesota: U.S. Geological Survey Water-Resources Investigations Report 87-4224, 3 sheets.

1987, Water-quality characteristics in glacial-drift aquifers in Minnesota [abs.]: Annual Meeting of the Geological Society of America, North Central Section, 21 st, St. Paul, Minnesota, April 30-May 1, 1987, Proceedings: Geological Society of America, p. 241.

1989, Water resources of the White Earth Indian Reservation, northwestern Minnesota: U.S. Geological Survey Water-Resources Investigations Report 89-4074, 73 p. 
1990, Water resources of the Red Lake Indian Reservation, northwestern Minnesota: U.S. Geological Survey Water-Resources Investigations Report 90-4163, 49 p.

1994, Nitrate-N concentration distribution and the presence of selected pesticides in the surficial sand aquifer of the Straight River Basin, north-central Minnesota, $1991-93$ [abs.]: Midwest Ground-Water Conference, 39th, Bismarck, North Dakota, October 16-18, 1994 [Proceedings], p. 28.

1994, Quality of ground water around Vadnais Lake and in Lambert Creek watershed, and interaction of ground water with Vadnais Lake, Ramsey County, Minnesota: U.S. Geological Survey Water-Resources Investigations Report 94-4062, 59 p.

Ruhl, J.F., and Adolphson, D.G., 1986, Hydrogeologic and water-quality characteristics of the Red River, Winnipeg aquifer, northwestern Minnesota: U.S. Geological Survey Water-Resources Investigations Report 84-4111, 2 sheets.

Ruhl, J.F., and Wolf, R.J., 1983, Hydrogeologic and water-quality characteristics of the St. Peter aquifer, southeast Minnesota: U.S. Geological Survey Water-Resources Investigations Report 83-4200, 2 sheets.

1984, Hydrogeologic and water quality characteristics of the Upper Carbonate aquifer, southeastern Minnesota: U.S. Geological Survey Water-Resources Investigations Report 84-4150, 2 sheets.

Ruhl, J.F., Wolf, R.J., and Adolphson, D.G., 1982, Hydrogeologic and water-quality characteristics of the IrontonGalesville aquifer, southeast Minnesota: U.S. Geological Survey Water-Resources Investigations Report 824080,2 sheets.

1983, Hydrogeologic and water-quality characteristics of the Prairie du Chien-Jordan aquifer, southeast Minnesota: U.S. Geological Survey Water-Resources Investigations Report 83-4045, 2 sheets.

Schneider, W.J., 1970, Hydrologic implications of solid-waste disposal: U.S. Geological Survey Circular 601-F, 10 p.

Schneider, W.J., Rickert, D.A., and Spieker, A.M., 1972, Role of water in urban planning and management: U.S. Geological Survey Circular 601-H, $10 \mathrm{p}$.

Schottler, S.P., Eisenreich, S.J., and Capel, P.D., 1990, Hydrologic and chemical controls on atrazine and alachlor in the Minnesota River [abs.]: EOS, Transactions, American Geophysical Union, v. 71, no. 43, p. 1330.

1991, Relations between water discharge and herbicide concentration in the Minnesota River, Minnesota, in Mallard, G.E., and Aronson, D.A., eds., U.S. Geological Survey Toxic Substances Hydrology ProgramProceedings of the technical meeting Monterey, California, March 11-15, 1991: U.S. Geological Survey WaterResources Investigations Report 91-4034, p. 338-342.

Schulze, P.A., and Capel, P.D., 1989, Utility and limitations of immunoassay tests as a field screening method for triazine herbicides [abs.], in Pederson, G.L., and Smith, M.M., compilers, U.S. Geological Survey Second National Symposium on Water Quality-Abstracts of the technical sessions, Orlando, Florida, November, 1217, 1989: U.S. Geological Survey Open-File Report 89-409, p. 86.

Schulze, P.A., Capel, P.D., Squillace, P.J., and Helsel, D.R., 1993, A laboratory and field evaluation of a portable immunoassay test for triazine herbicides in environmental water samples: International Journal of Environmental Analytical Chemistry, v. 53, p. 307-319.

Siegel, D.I., 1981, Effect of snowmelt on the water quality of Filson Creek and Omaday Lake, northeastern Minnesota: U.S. Geological Survey Water-Resources Investigations Report 81-66, 81 p.

1981, The effect of snow melt on water quality of Filson Creek and Omaday Lake, northeastern Minnesota: Water Resources Research, v. 17, no. 1, p. 238-242. 
1981, Hydrogeologic setting of the glacial Lake Agassiz peatlands, northern Minnesota: U.S. Geological Survey Water-Resources Investigations Report 81-24, 30 p.

1989, Geochemistry of the Cambrian-Ordovician aquifer system in the northern midwest United States: U.S. Geological Survey Professional Paper 1405-D, 76 p.

Siegel, D.I., and Ericson, D.W., 1980, Hydrology and water quality of the copper-nickel study region, northeastern Minnesota: U.S. Geological Survey Water-Resources Investigations Report 80-739, 87 p.

Siegel, D.I., Kontis, A.L., and Mandle, R.J., 1981, The chemical evolution of water quality in the CambrianOrdovician aquifer, north-central United States 1981 [abs.]: Midwest Meeting of the American Geophysical Union, Minneapolis, Minnesota, September 17-18, 1981, Proceedings: American Geophysical Union, p. 8.

1982, The chemical evolution of water quality in the Cambrian-Ordovician aquifer, north-central United States [abs.]: EOS, Transactions, American Geophysical Union, v. 63, no. 33, p. 612.

Siegel, D.I., and Mandle, R.J., 1982, Geochemical evidence for Pleistocene glacial meltwater recharge to the Cambrian-Ordovician aquifer in the north-central United States [abs.]: Geological Society of America Abstracts with Programs 1982, v. 14, no.5, p. 288.

Siegel, D.I., and Winter, T.C., 1980, Hydrologic setting of Williams Lake, Hubbard County, Minnesota: U.S. Geological Survey Open-File Report 80-403, 56 p.

Smith, C.J., Payne, G.A., and Tornes, L.H., 1990, Effects of impoundments on water quality of streams in the Coteau des Prairie - Upper Minnesota River Basin: U.S. Geological Survey Water-Resources Investigations Report 90-4033, $67 \mathrm{p}$.

1990, Hydrologic and water-quality data for streams and impoundments in the Coteau des Prairie- Upper Minnesota River Basin: U.S. Geological Survey Open-File Report 88-84, 43 p.

Smith, S.E., 1991, Water-quality indicators in the Prairie du Chien-Jordan aquifer, southeastern Minnesota: U.S. Geological Survey Open-File Report 91-480, 2 p.

1992, Water-quality indicators in the Prairie du Chien-Jordan aquifer, southeastern Minnesota [abs.]: Annual Midwest Ground-Water Conference, 37th, Souix Falls, South Dakota, October 14-16, 1992 [Proceedings], p. 41.

1994, Water-quality along selected flow paths in the Prairie du Chien-Jordan aquifer, southeastern Minnesota [abs.]: Geological Society of America Abstracts with Programs, v. 26, no. 5, p. 61-62.

Smith, S.E., and Hult, M.F., 1993, Crude-oil spill research project near Bemidji, Minnesota—A bibliography, 19841994: U.S. Geological Survey Open-File Report 93-373, 15 p.

1993, Hydrogeologic data collected from a crude oil spill site near Bemidji, Minnesota, 1983-91: U.S. Geological Survey Open-File Report 93-496, 158 p.

Soukup, W.G., 1980, Ground-water appraisal in northwestern Big Stone County, west-central Minnesota: U.S. Geological Survey Open-File Report 80-568, 41 p.

Soukup, W.G., Gillies, D.C., and Myette, C.F., 1984, Appraisal of the surficial aquifers in the Pomme de Terre and Chippewa River Valleys, western Minnesota: U.S. Geological Survey Water-Resources Investigations Report 84-4086, 63 p.

Stark, J.R., 1992, Stream-aquifer relations along Straight River, Becker and Hubbard Counties, Minnesota [abs.]: Annual Midwest Ground Water Conference, 37th, Souix Falls, South Dakota, October 14-16, 1992 [Proceedings], p. 36. 
-1994. National Water-Quality Assessment Program for the Upper Mississippi River Basin: U.S. Geological Survey Open-File Report 94-101, 2 p.

-1994, Plans for a water quality assessment of the Upper Mississippi River Basin [abs.]: Annual Meeting of the Mississippi River Research Consortium, 26th, LaCrosse, Wisconsin, April 28-29, 1994 [Proceedings], p. 18.

1994, Plans for water-quality assessment of the Upper Mississippi River Basin [abs.]: Sustaining the Ecological Integrity of Large Floodplain Rivers-Application of Ecological Knowledge to River Management, LaCrosse, Wisconsin, July 12-15, 1994 [Proceedings], p. 157.

1994, Upper Mississippi River Basin water quality assessment [abs.]: Minnesota Water '94 Managing Minnesota's Rivers and Watersheds, Minneapolis, Minnesota, April 21-22, 1994 [Proceedings], p. 16.

Stark, J.R., Armstrong, D.S., and Zwilling, D.R., 1994, Stream-aquifer interactions in the Straight River area, Becker and Hubbard Counties, Minnesota: U.S. Geological Survey Water-Resources Investigations Report $94-$ 4009, 83 p.

Stark, J.R., and Brown, R.G., 1987, Hydrology and water quality of a wetland used to receive wastewater effluent, St. Joseph, Minnesota, in National Wetland Symposium, Chicago, Illinois, September 16-18, 1987, Proceedings: Association of State Wetland Managers, Inc., p. 197-204.

Stark, J.R., Busch, J.P., and Deters, M.H., 1990, Hydrogeology and water quality of glacial-drift aquifers in the Bemidji-Bagley area, Beltrami, Clearwater, Cass, and Hubbard Counties, Minnesota: U.S. Geological Survey Water-Resources Investigations Report 89-4136, 135 p.

Stark, J.R., and Hult, M.F., 1985, Ground-water flow in the Prairie du Chien-Jordan aquifer related to contamination by coal-tar derivatives, St. Louis Park, Minnesota: U.S. Geological Survey Water-Resources Investigations Report 85-4087, 57 p.

-1985, Simulation of ground-water flow in the Prairie du Chien-Jordan aquifer and relation to ground-water contamination by coal-tar derivatives, St. Louis Park. Minnesota [abs.]: Annual Midwest Ground Water Conference, 30th, St. Paul, Minnesota, October 23-25, 1985 [Proceedings], p. 14.

1985, Simulation of ground-water flow in the Prairie du Chien-Jordan aquifer and relation to ground-water contamination by coal-tar derivatives, St. Louis Park, Minnesota: National Water Well Association Conference Exposition, Worthington, Ohio, August 19-20, 1985, Proceedings: National Water Well Association, p. $290-310$.

Stark, J.R., Strudell, J.D., Bloomgren, P.A., and Eger, Paul, 1987, Ground-water and soil contamination near two pesticide-burial sites in Minnesota: U.S. Geological Survey Water-Resources Investigations Report 87-4115, 48 p.

Stark, J.R., and Zwilling, D.R., 1989, Effects of ground-water withdrawal for irrigation and quality of Straight River, north-central Minnesota [abs.]: Annual Midwest Ground Water Conference, 34th, Kalamazoo, Michigan, October 18-20, 1987, Proceedings: Western Michigan University, p. 11.

-1989. Effects of ground-water withdrawals for irrigation on the quality of the Straight River, north-central Minnesota: U.S. Geological Survey Open-File Report 89-252, 2 p.

-1990, Effects of ground-water withdrawal for irrigation and quality of Straight River, north-central Minnesota [abs.]: Transferring Models to Users, Denver, Colorado, November 4-9, 1990, Proceedings: American Water Resources Association, p. I.

Stoner, J.D., 1985, Simulation of ground-water flow near a former wood-treating waste site in Fridley, MinnesotaPart II. A practical application of an analytic-element model [abs.]: Annual Midwest Ground Water Conference, 30th, St. Paul, Minnesota, October 23-25, 1985 [Proceedings], p. 18. 
-1991, National Water-Quality Assessment Program—Red River of the North: U.S. Geological Survey OpenFile Report 91-151, 2 p.

Stoner, J.D., Brigham, M.E., and Cowdery, T.K., 1994, Water-quality in surficial glacial-deposit aquifers in the Red River of the North drainage basin, Minnesota, North Dakota, and South Dakota [abs.]: Midwest Ground Water Conference, 39th, Bismarck, North Dakota, October 16-18, 1994 [Proceedings], p. 15.

Stoner, J.D., and Lorenz, D.L., 1992, Water-quality assessment strategy for the Red River of the North Basin, North Dakota, South Dakota, and Minnesota [abs.]: North Dakota Water Quality Symposium, Bismarck, North Dakota, March 25-26, 1992, Proceedings: North Dakota State University Extension Service, p. 291.

Swain, E.B., Engstrom, D.R., Brigham, M.E., Henning, T.A., and Brezonik, P.L., 1992, Increasing rates of atmospheric mercury deposition in midcontinental North America: Science, v. 257, p. 784-787.

Thomas, H.E., and Schneider, W.J., 1970, Water as an urban resource and nuisance: U.S. Geological Survey Circular 601-D, 9 p.

Tornes, L.H., 1980, Preimpoundment water quality of the Wild Rice River, Norman County, Minnesota: U.S. Geological Survey Water-Resources Investigations Report 80-79, $36 \mathrm{p}$.

1981, Quality of surface water before implementation of a flood-control project in Chaska, Minnesota: U.S. Geological Survey Water-Resources Investigations Report 81-83, 53 p.

1985, Suspended sediment in Minnesota streams: U.S. Geological Survey Water-Resources Investigations Report 85-4312, $33 \mathrm{p}$.

1989, Effect of urban runoff on the water quality of lakes in Eagan, Minnesota: U.S. Geological Survey WaterResources Investigations Report 86-4331, 64 p.

Tornes, L.H., and Brigham, M.E., 1994, Agricultural chemicals in streams of the Red River of the North drainage basin [abs.]: Minnesota Water '94 Managing Minnesota's Rivers and Watersheds, Minneapolis, Minnesota, April 21-22, 1994 [Proceedings], p. 3.

1994, Nutrients, suspended sediment, and pesticides in waters of the Red River of the North Basin, Minnesota, North Dakota, and South Dakota, 1970-90: U.S. Geological Survey Water-Resources Investigations Report 93$4231,62 \mathrm{p}$.

Tornes, L.H., and Have, M.R., 1980, Water quality of four lakes in Lakeville, Minnesota: U.S. Geological Survey Water-Resources Investigations Report 80-66, 51 p.

Tornes, L.H., Lorenz, D.L., Brigham, M.E., and Stoner, J.D., 1992, Plans for a water-quality assessment of the Red River of the North Basin, Minnesota, North Dakota, and South Dakota [abs.]: Minnesota Water '92Sustaining Water Resources in the ' 90 s and Beyond, Minneapolis, Minnesota, Proceedings: University of Minnesota Water-Resources Research Center.

Tornes, L.H., Puckett, L.J., Stoner, J.D., and Brigham, M.E., 1994 The effect of riparian wetlands in reducing nitrate nitrogen from a sand and gravel aquifer to a stream [abs.]: American Geophysical Union 1994 Fall Meeting, San Francisco, California, December 5-9, 1994, Proceedings: American Geophysical Union, p. 261.

U.S. Geological Survey, 1957, Supplemental chemical analysis of surface waters in the Red River of the North Basin, North Dakota and Minnesota: Unpublished report on file with U.S. Geological Survey in Mounds View, Minnesota, $40 \mathrm{p}$.

-1959, Chemical analysis of surface waters, Minnesota, October 1956 to September 1958: Unpublished report on file with U.S. Geological Survey in Mounds View, Minnesota, 16 p.

-1974, Status of projects in Minnesota, 1974-75 fiscal years: U.S. Geological Survey, 49 p. 
- 1975, Status of projects in Minnesota, fiscal years 1975-76: U.S. Geological Survey, 55 p.

- 1976, Status of projects in Minnesota, fiscal years 1976 and 1977: U.S. Geological Survey, 36 p

1977, Status of projects in Minnesota, fiscal years 1977 and 1978: U.S. Geological Survey, 59 p.

-1984, Ground-water contamination by crude petroleum at the Bemidji, Minnesota research site - Compilation of resource documents and project plan March 1984, variously paged.

VanVoast, W.A., 1971, Ground water for irrigation in the Brooten-Belgrade area, west-central Minnesota: U.S. Geological Survey Water-Supply Paper 1899-E, 24 p.

-1971, Ground water for irrigation near Lake Emily, Pope County, west-central Minnesota: U.S. Geological Survey Water-Supply Paper 1899-J, 28 p.

VanVoast, W.A., Broussard, W.L., and Wheat, D.E., 1972, Water resources of the Minnesota River-Hawk Creek watershed, southwestern Minnesota: U.S. Geological Survey Hydrologic Investigations Atlas HA-391, 3 sheets, scale $1: 250,000$.

VanVoast, W.A., Jerabek, L.A., and Novitzki, R.P., 1970, Water resources of the Redwood River watershed, southwestern Minnesota: U.S. Geological Survey Hydrologic Investigations Atlas HA-345, 3 sheets.

VanVoast, W.A., and Novitzki, R.P., 1968, Ground-water flow related to streamflow and water quality: Water Resources Research, v. 4, no. 4, p. 769-775.

Wanty, R.B., Tuttle, M.L., Landon, M.K., Delin, G.N., and Bohlke, J.K., 1993, Geochemistry of nitrogen in a farmed watershed near Princeton, Minnesota [abs.], in Morganwalp, D.W., and Aronson, D.A., compilers, U.S. Geological Survey Toxic Substances Hydrology Program—Abstracts of the technical meeting, Colorado Springs, Colorado, September 20-24, 1993: U.S. Geological Survey Open-File Report 93-454, p. 93.

Wershaw, R.L., and Fishman, M.J., 1983, Methods for the determination of organic substances in water and fluvial sediments: U.S. Geological Survey Techniques of Water-Resources Investigations, book 5, chap. A3, 173 p.

Winter, T.C., Bidwell, L.E., and Maclay, R.W., 1969, Water resources of the Otter Tail River watershed. westcentral Minnesota: U.S. Geological Survey Hydrologic Investigations Atlas HA-296, 4 sheets.

1970, Water resources of the Wild Rice River watershed, northwestern Minnesota: U.S. Geological Survey Hydrologic Investigations Atlas HA-339, 4 sheets, scale 1:250,000.

Winter, T.C., Maclay, R.W., and Pike, G.M., 1967, Water resources of the Roseau River watershed, northwestern Minnesota: U.S. Geological Survey Hydrologic Investigations Atlas HA-241, 3 sheets, scale 1:250,000.

Winterstein, T.A., 1982, Annotated report and data inventory for the Mississippi and Minnesota Rivers, MinneapolisSt. Paul metropolitan area: U.S. Geological Survey Open-File Report 82-869, 99 p.

- 1986, Water-resources activities of the U.S. Geological Survey in the Red River Valley, Minnesota fiscal year 1986: U.S. Geological Survey, 32 p.

Wolf, R.J., 1976, Buried aquifers in the Brooten-Belgrade and Lake Emily areas, west-central Minnesota-Factors related to developing water for irrigation: U.S. Geological Survey Water-Resources Investigations Report 76$100,72 \mathrm{p}$.

1981, Hydrogeology of the Buffalo aquifer, Clay and Wilkin Counties, west-central Minnesota: U.S. Geological Survey Water-Resources Investigations Report 81-4, $83 \mathrm{p}$.

Wolf, R.J., Ruhl, J.F., and Adolphson, D.G., 1983, Hydrogeologic and water-quality characteristics of the Mount Simon-Hinckley aquifer, southeast Minnesota: U.S. Geological Survey Water-Resources Investigations Report 83-4031, 2 sheets. 
Woodward, D.G., and Anderson, H.W., Jr., 1984, Hydrogeologic and water-quality characteristics of the

Cretaceous aquifer, southwestern Minnesota: U.S. Geological Survey Water-Resources Investigations Report 84-4153, 2 sheets. 


\section{Methods Of Data Collection}

Anderson, H.W., Jr., 1980, Minnesota standards for coding ground-water site inventory data: Unpublished report on file with U.S. Geological Survey in Mounds View, Minnesota, 57 p.

Beverage, J.P., and Futrell, J.C., 1986, Comparison of flume and towing methods for verifying the calibration of a suspended-sediment sampler: U.S. Geological Survey Water-Resources Investigations Report 86-4193, 11 p.

Beverage, J.P., and Skinner, J.V., 1973, Automatic tracking attachment for the visual-accumulation-tube size analyzer: Federal Inter-Agency Sedimentation Project. $15 \mathrm{p}$.

Brown, R.G., 1984, Precipitation and streamflow data-Collections techniques, in Understanding Watershed and Lake Management Conference, Bloomington, Minnesota, March 23, 1984 [Proceedings], p. 18-29.

1985. Errors associated with estimating ground-water flow and phosphorus flux components in hydrologic and phosphorous budgets of lakes [abs.]: Annual Midwest Ground Water Conference, 30th, St. Paul, Minnesota. October 23-25, 1985 [Proceedings], p. 3.

Capel, P.D., and Barbeau, D.S., 1991, Method for the systematic evaluation of organic chemical retention by solid phase extraction columns, in Mallard, G.E., and Aronson, D.A., eds., U.S. Geological Survey Toxic Substances Hydrology Program—Proceedings of the technical meeting, Monterey, California, March 11-15,1991: U.S. Geological Survey Water-Resources Investigations Report 91-4034, p. 330-333.

Colby, V.C., 1964. Instructions for use of BM-54 and BM-60 bed-material samplers for the collection of samples to be analyzed for organic substances: Federal Inter-Agency Sedimentation Project, $3 \mathrm{p}$.

- 1965, Operating instructions for US DH-48 suspended-sediment hand sampler: Federal Inter-Agency Sedimentation Project Report J, 5 p.

Colby, V.C., and Witzgman, F.W., 1958, Operator's manual on the visual-accumulation tube method for sedimentation analysis of sands: Federal Inter-Agency Sedimentation Project Report K, 28 p.

1962, Instructions for US P-61-A I suspended-sediment sampler: Federal Inter-Agency Sedimentation Project, 9 p.

Druffel, Leroy, Emmett, W.W., Schneider, V.R., and Skinner, J.V., 1976, Laboratory hydraulic calibration of the Helley-Smith bed-load-sediment sampler: U.S. Geological Survey Open-File Report 76-752, 63 p.

Ficke, J.F., and Hawkinson, R.O., 1975, The National Stream Quality Accounting Network (NASQAN)—Some questions and answers: U.S. Geological Survey Circular 719, 23 p.

Glysson, G.D., and Skinner, J.V., 1990, Relation between the national handbook of recommended methods for water data acquisition and ASTM standards, in Hall, J.R., and Douglas, G.D., eds., Monitoring Water in the 1990'sMeeting New Challenges: Philadelphia, Pennsylvania, American Society for Testing and Materials, p. 291-300.

Greeson, P.E., ed., 1979, A supplement to methods for collection and analysis of aquatic biological and microbiological samples: U.S. Geological Survey Techniques of Water-Resources Investigations, book 5, chap. A4, $92 \mathrm{p}$.

Hotchkiss, R.H., 1991, Particle size distributions by Pipet and sedigraph, in Ian, S.S., and Kuo, Y.H., eds., Federal Inter-Agency Sedimentation Conference, 5th, Las Vegas, Nevada, March 18-21, 1991, Proceedings: Federal Inter-Agency Sedimentation Project, v. 1, p. 6-47-6-54.

Hubbell, D.W., Stevens, H.H., Jr., Skinner, J.V., and Beverage, J.P., 1981, Recent refinements in calibrating bedload samplers, in Water Forum '81, San Francisco, California, August 10-14, 1981, Proceedings: American Society of Civil Engineers, v. 1, p. 128-140. 
1983, New approach to calibrating bed-load samplers: Journal of Hydraulic Engineering, v. III, no. 4, p. 677 694.

1987, Laboratory data on coarse-sediment transport for bedload-sampler calibrations: U.S. Geological Survey Water-Supply Paper 2299, $30 \mathrm{p}$.

Jaques, J.E., and Lorenz, D.L., 1988, Techniques for estimating the magnitude an frequency of floods in Minnesota: U.S. Geological Survey Water-Resources Investigations Report 87-4170, 48 p.

Lindholm, G.F., and Norvitch, R.F., 1976, Remote sensing as an aid in water-resources studies in Minnesota: U.S. Geological Survey Open-File Report 76-2I3, 63 p.

Nordin, C.F., and Skinner, J.V., 1977, Sediment sampling for deep fast currents, in International Association for Hydraulic Research, 17th, Badan Baden, Germany, August 14-19, 1977 [Proceedings], p. 606-609.

Schulze, P.A., Capel, P.D., Squillace, P.J., and Helsel, D.R., 1993, A laboratory and field evaluation of a portable immunoassay test for triazine herbicides in environmental water samples: International Journal of Environmental Analytical Chemistry, v. 53, p. 307-319.

Skinner, J.V., 1960, An automatic-tracking device for visual-accumulation-tube analysis: Water Resources Bulletin, November, p. 135-137.

1968, Field test of an x-ray sediment-concentration gage: American Society of Civil Engineers, Hy. 2, no. 5868 , $3 \mathrm{p}$.

1968, Field test results of the Model B panametrics radioisotope gage for monitoring suspended-sediment concentration in rivers and streams: Federal Inter-Agency Sedimentation Project, $37 \mathrm{p}$.

1976, Instructions for sampling with depth-integrating, suspended-sediment samplers D-74, D-74AL, D74TM, and D-74AL-TM: Federal Inter-Agency Sedimentation Project, $12 \mathrm{p}$.

1978, Instructions for the battery pack BP-76 HD: Federal Inter-Agency Sedimentation Project, 3 p.

1979, Instructions for the peristaltic pump, RP-77: Federal Inter-Agency Sedimentation Project, 5 p.

1979, Operating instructions D-77 suspended-sediment sampler: Federal Inter-Agency Sedimentation Project, $5 \mathrm{p}$.

1982, A fluid density gage for measuring suspended-sediment concentration, Part A. Gage response to steadystate and transient conditions: Federal Inter-Agency Sedimentation Project Report X, 125 p.

1986, Measurement of scour depth near bridge piers: U.S. Geological Survey Water-Resources Investigations Report 85-4106, $33 \mathrm{p}$.

1986, Sampling suspended sediment in ice-covered rivers: International Northern Research Basins Symposium, 6th, Michigan Technology University, January 26-30, 1986 [Proceedings], p. 105-108.

1987, Progress report on temperature effects in vibrational type sediment-concentration gages: Federal InterAgency Sedimentation Project Report II, 48 p.

1989, Model B sediment concentration gage-Factors influencing its readings and a formula for correcting its errors in measurement and analysis of sediment load in streams: Federal Inter-Agency Sedimentation Project Report JJ, 34 p.

Skinner, J.V., and Beverage, J.P., 1976, Instrumentation automatic collection of sediment data, in Federal InterAgency Sedimentation Conference, 3rd, Denver, Colorado, March 22-25, 1976, Proceedings: Federal InterAgency Sedimentation Project, p. 7-1-7-16. 
1981, Test and design of automatic fluvial suspended-sediment samplers: Federal Inter-Agency Sedimentation Project, $53 \mathrm{p}$.

1986, Continuous measurement of suspended-sediment concentration: Federal Inter-Agency Sedimentation Conference, 4th, Las Vegas, Nevada, March 24-27, 1986, Proceedings: Federal Inter-Agency Sedimentation Project, p. 1.29 to 1.39 .

Skinner, J.V., and Szalona, J.J., 1991, Gages for measuring fluvial-sediment concentration, in Ian, S.S., and Kuo, Y.H., eds., Federal Inter-Agency Sedimentation Conference, 5th, Las Vegas, Nevada, March 18-21, 1991 : Proceedings: Federal Inter-Agency Sedimentation Project, p. 2.1-2.8.

Stoner, J.D., and Streitz, A.R., 1987, Locating confined aquifers in glacial drift with seismic reflection methods, western Minnesota [abs.]: Annual Meeting of the Geological Society of America, North Central Section, 21 st, St. Paul, Minnesota, April 30-May 1, 1987, Proceedings: Geological Society of America, p. 248.

Trotta, L.C., 1988, Aggregation of Minnesota water-use data and transfer of data to the National water-use data system-Procedures and programs: U.S. Geological Survey Open-File Report 87-40, 71 p.

1988, Sources of water-use data in Minnesota: U.S. Geological Survey Open-File Report 87-544, 2 p.

1990, Automation of data systems $\longrightarrow$ Minnesota's approach for water-use data, in Wiltshire, D.A.,ed., Selected papers in applied computer sciences 1990: U.S. Geological Survey Bulletin 1908, p. F1-F4.

Trotta, L.C., Roddy, W.R., Rowan, M.C., and Wilson, E.J., 1992, Source and authority for national water information system II support files [abs.], in Balthrop, B.H., and Baker, E.G., eds., U.S. Geological National Computer Technology Meeting-Program and abstracts, Norfolk, Virginia, May 17-22, 1992: U.S. Geological Survey Open-File Report 92-64, p. 36.

Wershaw, R.L., and Fishman, M.J., 1983, Methods for the determination of organic substances in water and fluvial sediments: U.S. Geological Survey Techniques of Water-Resources Investigations, book 5, chap. A3, 173 p.

Winterstein, T.A., and Stefan, H.G., 1986, Effects of nozzle orientation on sediment sampling: Federal Inter-Agency Sedimentation Conference, 4th, Las Vegas, Nevada, March 24-27, 1986, Proceedings: Federal Inter-Agency Sedimentation Project, p. 1.20-1.28. 


\section{Hydrologic Modeling}

Baehr, A.L., and Hult, M.F. 1987, Mathematical modeling of hydrocarbon and oxygen transport coupled with microbial degradation in the unsaturated zone [abs.], in Franks, B.J., ed., U.S. Geological Survey program on toxic waste - ground-water contamination-Proceedings of the third technical meeting. Pensacola, Florida, March 23-27, 1987: U.S. Geological Survey Open-File Report 87-109, p. C-27-C28.

Carlson, G.H., 1991, Simulation of effects of ground-water development on water levels in glacial-drift aquifers in the Brooten-Belgrade area, west-central Minnesota: U.S. Geological Survey Water-Resources Investigations Report 88-4193, 66 p.

Delin, G.N., 1985, Confined-drift aquifers studied near the Pomme de Terre and Chippewa Rivers, west-central Minnesota: U.S. Geological Survey Open-File Report, 2 p.

-1987, Evaluation of availability of water from drift aquifers near the Pomme de Terre and Chippewa Rivers, western Minnesota: U.S. Geological Survey Water-Resources Investigations Report 86-4321, 53 p.

1990, Hydrogeology and simulation of ground-water flow in the Rochester area, southeast Minnesota, 197888: U.S. Geological Survey Water-Resources Investigations Report 90-4081, 102 p.

1990. Hydrologic considerations for delineating ground water recharge arcas for wells, Rochester, Minnesota [abs.]: Minnesota water 1990-Facing Environmental Challenges of the 1990's, St. Paul, Minnesota, April 1990, Proceedings: Minnesota Water Resources Research, p. 42-43.

Delin, G.N., and Almendinger, J.E., 1991, Delineation of recharge areas for selected wells in the St. Peter-Prairie du Chien-Jordan aquifer, Rochester, Minnesota: U.S. Geological Survey Open-File Report 90-397, 60 p.

1993, Delineation of recharge areas for selected wells in the St. Peter-Prairie du Chien-Jordan aquifer, Rochester, Minnesota: U.S. Geological Survey Water-Supply Paper 2397, 39 p.

Guswa, J.H., Siegel, D.I., and Gillies, D.C., 1982, Preliminary evaluation of the ground-water-flow system in the Twin Cities metropolitan area, Minnesota: U.S. Geological Survey Water-Resources Investigations Report 82$44,65 \mathrm{p}$.

Helgesen J.O., 1977, Ground-water appraisal of the Pineland Sands area, central Minnesota: U.S. Geological Survey Water-Resources Investigations Report 77-102, 49 p.

Larson, S.P.. 1976, An appraisal of ground water for irrigation in the Appleton area, west-central Minnesota: U.S. Geological Survey Water-Supply Paper 2039-B, 34 p.

Larson, S.P., McBride, M.S., and Wolf, R.J., 1975, Digital models of a glacial outwash aquifer in the Pearl-Sallie Lakes area, west-central Minnesota: U.S. Geological Survey Water-Resources Investigations Report 75-40, 39 p.

Lindgren, R.J., 1990, Simulation of ground-water flow in the Prairie du Chien-Jordan and overlying aquifers near the Mississippi River, Fridley, Minnesota: U.S. Geological Survey Water-Resources Investigations Report 90-4165, $152 \mathrm{p}$.

Lindholm, G.F., 1980, Ground-water appraisal of sand plains in Benton, Sherburne, Stearns, and Wright Counties, central Minnesota: U.S. Geological Survey Water-Resources Investigations Report 80-1285, 103 p.

Lorenz, D.L., and Stark, J.R., 1990, Simulation of ground-water flow in the St. Peter aquifer in an area contaminated by coal-tar derivatives, St. Louis Park, Minnesota: U.S. Geological Survey Water-Resources Investigations Report 90-4150, $37 \mathrm{p}$.

Miller, R.T., 1982, Appraisal of the Pelican River Sand-Plain aquifer, western Minnesota: U.S. Geological Survey Open-File Report 82-347, $44 \mathrm{p}$. 
- 1984, Preliminary modeling of an aquifer thermal-energy storage system: U.S. Geological Survey Open-File Report 84-811, $47 \mathrm{p}$.

1985, Preliminary modeling of an aquifer thermal-energy storage system. in Subitzky, Seymour, ed., Selected papers in hydrologic sciences: U.S. Geological Survey Water-Supply Paper 2270. p. 1-19.

1988. Hydrogeology and preliminary regional flow modeling at the Bemidji, Minnesota research site, in Ragone, S.E., ed., U.S. Geological Survey program on toxic waste - ground-water contamination-Proceedings of the second technical meeting Cape Cod, Massachusetts, October 21-25, 1985: U.S. Geological Survey OpenFile Report 86-481, p. C11-C16.

- 1989, Cyclic injection, storage. and withdrawal of heated water in a sandstone aquifer at St. Paul, MinnesotaField observations, preliminary model analysis and aquifer thermal-energy efficiency: U.S. Geological Survey Open-File Report 89-261, 97 p.

Miller, R.T., and Delin, G.N., 1993, Field observations, preliminary model analysis, and aquifer thermal efficiencyCyclic injection, storage and withdrawal of heated water in a sandstone aquifer at St. Paul, Minnesota: U.S. Geological Survey Professional Paper 1530-A, 55 p

Miller, R.T., and Voss, C.I., 1986, Finite difference grid for a doublet well in an anisotropic aquifer: Ground Water, v. 24 , no. 4 , p. $490-496$.

Myette, C.F., 1984, Appraisal of water from surficial-outwash aquifers in Todd County and parts of Cass and Morrison Counties, central Minnesota: U.S. Geological Survey Water-Resources Investigations Report 83-4156, $43 \mathrm{p}$.

1985, Hydrogeology of sand-plain aquifers in Carlton, Kanabec, and Pine Counties, east-central Minnesota: U.S. Geological Survey Water-Resources Investigations Report 85-4334. 66 p.

1991, Hydrology, water quality, and simulation of ground-water flow at a taconite tailings basin near Keewatin. Minnesota: U.S. Geological Survey Water-Resources Investigations Report 88-4230, 61 p.

Schoenberg, M.E., 1981, Evaluation of geohydrologic data using a ground-water-flow model of the Twin Cities metropolitan area, Minnesota [abs.]: Annual Meeting, 94th, Cincinnati, Ohio, November 2-5, 1981, Proceedings: Geological Society of America, p. 548.

1987, Effects of future ground-water withdrawals on water levels in the Twin Cities aquifer system, Minnesota [abs.]: Annual Meeting of the Geological Society of America, North Central Section, 21st. St. Paul, Minnesota, April 30-May 1, 1987, Proceedings: Geological Society of America, p. 242-243.

1990, Effects of present and projected ground-water withdrawals on the Twin Cities aquifer system, Minnesota: U.S. Geological Survey Water-Resources Investigations Report 90-4001, 165 p.

Schoenberg, M.E., and Guswa, J.H., 1981, Evaluating ground-water data by a flow model of the Twin Cities metropolitan area, Minnesota [abs.]: Midwest Meeting of the American Geophysical Union, Minneapolis, Minnesota, September 17-18, 1981, Proceedings: American Geophysical Union, p. 8.

- 1982, Evaluating ground-water data by a flow model of the Twin Cities metropolitan area, Minnesota [abs.]: EOS, Transactions, American Geophysical Union, v. 63, no. 33, p. 612 .

Siegel, D.I., 1981, Hydrogeologic setting of the glacial Lake Agassiz peatlands, northern Minnesota: U.S. Geological Survey Water-Resources Investigations Report 81-24, $30 \mathrm{p}$.

Siegel, D.I., and Winter, T.C., 1980, Hydrologic setting of Williams Lake, Hubbard County, Minnesota: U.S. Geological Survey Open-File Report 80-403, 56 p. 
Soukup, W.G., Gillies, D.C., and Myette, C.F., 1984, Appraisal of the surficial aquifers in the Pomme de Terre and Chippewa River Valleys, western Minnesota: U.S. Geological Survey Water-Resources Investigations Report 84-4086, $63 \mathrm{p}$.

Stark, J.R., Armstrong, D.S., and Zwilling, D.R., 1994, Stream-aquifer interactions in the Straight River area, Becker and Hubbard Counties, Minnesota: U.S. Geological Survey Water-Resources Investigations Report 94$4009,83 \mathrm{p}$.

Stark, J.R., and Hult, M.F., 1985, Ground-water flow in the Prairie du Chien-Jordan aquifer related to contamination by coal-tar derivatives, St. Louis Park, Minnesota: U.S. Geological Survey Water-Resources Investigations Report 85-4087, $57 \mathrm{p}$.

1985, Simulation of ground-water flow in the Prairie du Chien-Jordan aquifer and relation to ground-water contamination by coal-tar derivatives, St. Louis Park, Minnesota [abs.]: Annual Midwest Ground Water Conference, 30th, St. Paul, Minnesota, October 23-25, 1985 [Proceedings], p. 14.

-1985, Simulation of ground-water flow in the Prairie du Chien-Jordan aquifer and relation to ground-water contamination by coal-tar derivatives, St. Louis Park, Minnesota: National Water Well Association Conference Exposition, Worthington, Ohio, August 19-20, 1985, Proceedings: National Water Well Association, p. 290-310.

Stoner, J.D., 1985, Simulation of ground-water flow near a former wood-treating waste site in Fridley, Minnesota Part II. A practical application of an analytic-element model [abs.]: Annual Midwest Ground Water Conference, 30th, St. Paul, Minnesota, October 23-25, 1985 [Proceedings], p. 18.

Stoner, J.D., and Schoenberg, M.E., 1989, Preliminary evaluation of effects of ground water withdrawals on Mississippi River flow near the Twin Cities metropolitan area, Minnesota [abs.]: Water Supply Issues in the Metropolitan Twin Cities area-Planning for the Future Droughts and Population Growth, St. Paul, Minnesota, October 25, 1988, Proceedings: Minnesota Water Resources Research, p. 5-6.

Trescott, P.C., Pinder, G.F., and Larson, S.P., 1976, Finite-difference model for aquifer simulation in two dimensions with results of numerical experiments: U.S. Geological Survey Techniques of Water-Resources Investigations, book 7 , chap. $\mathrm{Cl}, 116 \mathrm{p}$.

Wolf, R.J., 1981, Hydrogeology of the Buffalo aquifer, Clay and Wilkin Counties, west-central Minnesota: U.S. Geological Survey Water-Resources Investigations Report 81-4, 83 p. 


\section{Miscellaneous}

Baehr, A.L., and Hult, M.F., 1989, Determination of the air-phase permeability tensor of an unsaturated zone at the Bemidji, Minnesota research site, in Mallard, G.E., and Ragone, S.E., eds., U.S. Geological Survey Toxic Substances Hydrology Program-Proceedings of the technical meeting, Phoenix, Arizona, September 26-30, 1988: U.S. Geological Survey Water-Resources Investigations Report 88-4220, p. 55-62.

1991, Evaluation of unsaturated zone air permeability through pneumatic tests: Water Resources Research, v. 27 , no. 10 , p. $2605-2617$.

Bath, G.D., Schwartz, G.M., and Gilbert, F.P., 1964, Aeromagnetic and geologic map of northwestern Minnesota: U.S. Geological Survey Geophysical Investigations Map GP-471, 1 sheet, scale 1:250,000.

Books, K.G., Schwartz, G.M., Meuschke, J.L., and Dempsey, W.J., 1958, Aeromagnetic maps of eastern Roseau County, Minnesota: U.S. Geological Survey Geophysical Investigations Map GP-140, 2 sheets, scale 1:63,360.

-1958, Aeromagnetic map of Kittson County, Minnesota: U.S. Geological Survey Geophysical Investigations Map GP-142, 2 sheets, scale 1:63,360.

1958, Aeromagnetic maps of western Roseau County, Minnesota: U.S. Geological Survey Geophysical Investigations Map GP-141, 2 sheets, scale 1:63,360.

Brigham, M.E., 1994, Pesticides detected in surface waters and fish of the Red River of the North drainage basin [abs.]: North Dakota Water-Quality Symposium, 4th biennial, Fargo, North Dakota, March 30-31, 1994, Proceedings: North Dakota State University Extension Service, p. 26.

- 1994, Pesticides detected in surface waters and fish of the Red River of the North drainage basin, in North Dakota Water-Quality Symposium, 4th biennial, Fargo, North Dakota, March 30-31, 1994, Proceedings: North Dakota State University Extension Service, p. 256-269.

Brown, R.G., 1983, Atmospheric deposition of selected chemicals and their effect on nonpoint-source pollution in the Twin Cities metropolitan area, Minnesota: U.S. Geological Survey Water-Resources Investigations Report 83$4195,24 \mathrm{p}$.

Capel, P.D., 1990, Atmospheric deposition of herbicides in Minnesota [abs.]: Minnesota water 1990-Facing Environmental Challenges of the 1990's, St. Paul, Minnesota, April 1990, Proceedings: Minnesota Water Resources Research, p. 27.

-1990, Atmospheric deposition of herbicides in the midcontinental United States [abs.]: EOS, Transactions, American Geophysical Union, v. 71, no. 43, p. 1329.

-1990, A bibliography of atrazine and its simple degradation products in the environment: U.S. Geological Survey Open-File Report 89-613, 5 p.

1991, Wet atmospheric deposition of herbicides in Minnesota, in Mallard, G.E., and Aronson, D.A., eds., U.S. Geological Survey Toxic Substances Hydrology Program-Proceedings of the technical meeting, Monterey, California, March 11-15, 1991: U.S. Geological Survey Water-Resources Investigations Report 91-4034, p. 334337.

Chang, Fu-Hsian, Hult, M.F., and Noben, N.N., 1987, Quantitative studies of biodegradation of petroleum and some model hydrocarbons in ground water and sediment environments, in Fairchild, D.M., ed., Ground-water quality and agricultural practices: Chelsea, Michigan, Lewis Publishers, p. 295-318.

Cotter, R.D., and Rogers, J.E., 1964, Glacial geology of the Mountain Iron-Virginia-Eveleth area Mesabi Iron Range, Minnesota: U.S. Geological Survey Professional Paper 501-C, p. C144-Cl46. 
Cotter, R.D., Young, H.L., and Winter, T.C., 1964, Preliminary surficial geologic map of the Mesabi-Vermillion Iron Range area northeastern Minnesota: U.S. Geological Survey Miscellaneous Geologic Investigations Map 1403, 1 sheet, scale 1:125,000.

Czarnecki, J.B., 1983, Fortran computer programs to plot and process aquifer pressure and temperature data: U.S. Geological Survey Water-Resources Investigations Report 83-4051, 50 p.

Delin, G.N., Landon, M.K., Healy, R.W., and Olsen, H.W., 1993, Spatial variability of unsaturated-zone properties in relation to topography in a sand-plain setting near Princeton. Minnesota [abs.], in Morganwalp. D.W., and Aronson, D.A., compilers, U.S. Geological Survey Toxic Substance Hydrology Program -Abstracts of the technical meeting, Colorado Springs, Colorado, September 20-24, 1993: U.S. Geological Survey Open-File Report 93-454, p. 92.

1994. Spatial distribution of unsaturated-zone properties in relation to topography near Princeton. Minnesota [abs.]: Minnesota Water '94-Managing Minnesota's Rivers and Watersheds, Minneapolis, Minnesota, April 21-22, 1994 [Proceedings], p. 9.

Goldstein, R.M., Simon, T.P., Bailey, P.A., Ell, Michael, Pearson, Eric, Schmidt, Konrad, and Enblom, J.W., 1994, Concepts for an index of biotic integrity for streams of the Red River of the North Basin [abs.]: North Dakota Water-Quality Symposium, 4th biennial, Fargo, North Dakota, March 30-31, 1994, Proceedings: North Dakota State University Extension Service, p. 19.

1994, Concepts for an index of biotic integrity for streams of the Red River of the North Basin, in North Dakota Water-Quality Symposium, 4th biennial, Fargo, North Dakota, March 30-31, 1994, Proceedings: North Dakota State University Extension Service, p. 169-180.

Hatch, J.R., and Morey, G.B., 1984, Hydrocarbon source rock evaluation-Solo Church Formation (middle Proterozoic, Keeweenawan Supergroup), southeastern Minnesota: U.S. Geological Survey Open-File Report 84$554,17 \mathrm{p}$.

Hult, M.F., 1987, Microbial oxidation of petroleum vapors in the unsaturated zone [abs.] in Franks, B.J., ed., U.S. Geological Survey program on toxic waste-ground water contamination-Proceedings of the third technical meeting, Pensacola, Florida, March 23-27, 1987: U.S. Geological Survey Open-File Report 87-109 p. C25-C26.

Komor, S.C., 1994, Petrography and chemistry of calcite in the KTB borehole, Germany [abs.]: International Symposium on the Observation of the Continental Crust Through Drilling, 7th, Sante Fe, New Mexico, April 2530, 1994 [Proceedings].

Komor, S.C., and Emerson, D.G., 1994, Movements of water, solutes, and stable isotopes in the unsaturated zones of two sand plains in the Upper Midwest: Water Resources Research, v. 30, no. 2, p. 253-267.

Larson-Higdem, D.C., 1976, Map showing altitude of the bedrock surface in Minnesota: U.S. Geological Survey Open-File Report 76-788, 1 sheet.

Lindholm, G.F., and Norvitch, R.F., 1976, Remote sensing as an aid in water-resources studies in Minnesota: U.S. Geological Survey Open-File Report 76-213, 63 p.

Lorenz, D.L., 1990, A method for describing stream-drainage system topology in a geographic information system [abs.], in Balthrop, B.H., and Baker, E.G., compilers, U.S. Geological Survey National Computer Technology Meeting - Program and abstracts, San Antonio, Texas, May 7-11, 1990: U.S. Geological Survey Open-File Report 90-161, p. 22.

1991, Describing stream-drainage systems using a geographic information system [abs.]: Water Management of River Systems, New Orleans, Louisiana, September 8-13, 1991, Proceedings: American Water Resources Association, p. 285-286. 
1992. Integrating and aggregating data from stream-d:ainage systems using a geographic information system, in Wiltshire, D.A., ed., Selected papers in applied computer sciences 1992: U.S. Geological Survey Bulletin 2016. p. DI-D7.

- 1992. Using a geographic information system to describe the environmental setting of the Red River of the North Basin [abs.], in Balthrop, B.H., and Baker, E.G., eds., U.S. Geological Survey National Computer Technology Meeting--Program and abstracts, Norfolk, Virginia, May 17-22, 1992: U.S. Geological Survey Open-File Report 92-64, p. 21.

1994. Use of remotely sensed data to characterize vegetation in the Red River of the North Basin, Minnesota, North Dakota, and South Dakota [abs.], in Balthrop, B.H., and Baker, E.G., compilers, U.S. Geological Survey National Computer Technology Meeting Program and abstracts. New Orleans, Louisiana April 10-15, 1994: U.S. Geological Survey Open-File Report 94-52, p. 27.

Lorenz, D.L., and Trotta, L.C., 1991, Preparation and comparison of maps showing the depth to water table, Dakota County, Minnesota: U.S. Geological Survey Open-File Report 91-245, 2 p.

McIntosh, W.L., and Eister, M.F., 1972, Geologic map index of Minnesota Part B, 1953-1970: U.S. Geological Survey Minnesota Geologic Map Index, 1 sheet.

Norvitch, R.F., 1962, Geology of the Vermillion end moraine, Nett Lake Indian Reservation, Minnesota: U.S. Geological Survey Professional Paper 450-D, p. D130-D132.

Oakes, E.L., 1964, Bedrock topography of the eastern and central Mesabi Range, northeastern Minnesota: U.S. Geological Survey Miscellaneous Geologic Investigations Map I-389. 4 sheets.

Olcott, P.G., and Siegel, D.I., 1978, Physiography and surficial geology of the copper-nickel study region, northeastern Minnesota: U.S. Geological Survey Open-File Report 78-51, 22 p.

Rosenberry, D.O., Sturrock, A.M., Scarborough, J.L., and Winter, T.C., 1988, Climatic data for Williams Lake, Hubbard County, Minnesota, 1988: U.S. Geological Survey Open-File Report 88-304, 38 p.

1988, Climatic data for Williams Lake, Hubbard County, Minnesota: U.S. Geological Survey Open-File Report $88-89,42 \mathrm{p}$.

Scott, C.H., and Skinner, J.V., 1962, Valve position indicator for P-46 sampler: Water Resources Bulletin, February, p. 9-10.

Siegel, D.I., 1980, Dissolution kinetics of selected silicate minerals under acid conditions [abs.]: EOS, Transactions, American Geophysical Union, v. 61, p. 1152.

1987, Geochemical facies and mineral dissolution, Bemidji, Minnesota research site, in Franks, B.J., ed., U.S. Geological Survey program on toxic waste ground water contamination-Proceedings of the third technical meeting, Pensacola, Florida, March 23-27, 1987: U.S. Geological Survey Open-File Report 87-109, p. C13-C15.

Skinner, J.V., 1989, History of the Federal Interagency Sedimentation Project, in Sediment Transport Modeling International Symposium, New Orleans, Louisiana, August 14-18, 1989, Proceedings: American Society of Civil Engineers, p. 266-271.

Skinner, J.V., and Benson, D.A., 1982, Services provided by the Federal Inter-Agency Sedimentation Project: Federal Inter-Agency Sedimentation Project, 2 p.

Sturrock, A.M., Rosenberry, D.O., Engelbrecht, L.G., Gothard, W.A., and Winter, T.C., 1984, Climatic data from Williams Lake, Hubbard County, Minnesota, 1983: U.S. Geological Survey Open-File Report 84-247, 41 p.

Sturrock, A.M., Rosenberry, D.O., Scarborough, J.L., and Winter, T.C., 1986, Climatic data for Williams Lake, Hubbard County, Minnesota, 1984: U.S. Geological Survey Open-File Report 86-64, 62 p. 
Sturrock, A.M., Rosenberry, D.O., and Winter, T.C., 1987, Climatic data for Williams Lake, Hubbard County, Minnesota, 1985: U.S. Geological Survey Open-File Report 86-607, 40 p.

Swain, E.B, Engstrom, D.R., Brigham, M.E., Henning, T.A., and Brezonik, P.L., 1992, Increasing rates of atmospheric mercury deposition in midcontinental North America: Science, v. 257, p. 784-787.

Trotta, L.C., 1987, Ground water withdrawals in Minnesota [abs.], in Zaporozec, A., ed., Annual Midwest Ground Water Conference, 32nd, Madison, Wisconsin, October 28-30, 1987 [Proceedings].

1988, Aggregation of Minnesota water-use data and transfer of data to the National water-use data systemProcedures and programs: U.S. Geological Survey Open-File Report 87-40, 71 p.

1988, Sources of water-use data in Minnesota: U.S. Geological Survey Open-File Report 87-544, 2 p.

1988, Water use for aquaculture in Minnesota, 1984: U.S. Geological Survey Water-Resources Investigations Report 88-4159, $6 \mathrm{p}$.

- 1990, Automation of data systems —Minnesota's approach for water-use data, in Wiltshire, D.A.,ed., Selected papers in applied computer sciences 1990: U.S. Geological Survey Bulletin 1908, p. F1-F4.

1991, Automation of the water-use data base for Minnesota, in Balthrop, B.H., and Terry, J.E., eds., U.S.

Geological Survey National Computer Technology Meeting-Proceedings, Phoenix, Arizona, November 14-18, 1988: U.S. Geological Survey Water-Resources Investigations Report 90-4162, p. 131-137.

Trotta, L.C., and Horn, M.S., 1990, Importance of return flow as a component of water use: U.S. Geological Survey Open-File Report 90-179, 2 p.

Trotta, L.C., Roddy, W.R., Rowan, M.C., and Wilson, E.J., 1992, Source and authority for national water information system II support files [abs.], in Balthrop, B.H., and Baker, E.G., eds., U.S. Geological National Computer Technology Meeting-Program and abstracts, Norfolk, Virginia, May 17-22, 1992: U.S. Geological Survey Open-File Report 92-64, p. 36.

Winter, T.C., 1971, Sequence of glaciation in the Mesabi-Vermillion Iron Range area, northeastern Minnesota: U.S. Geological Survey Professional Paper 750-C, p. C82-C88.

Winterstein, T.A., and Miller, R.A., 1994, A collaborative approach to electronic report production [abs.], in Balthrop, B.H., and Baker, E.G., compilers, U.S. Geological Survey National Computer Technology MeetingProgram and abstracts, New Orleans, Louisiana, April 10-15, 1994: U.S. Geological Survey Open-File Report 94-52, p. 59.

Woodward, D.G., 1985, Seismic-refraction study of suspected drift-filled bedrock valleys in Minnesota: U.S. Geological Survey Water-Resources Investigations Report 85-4107, 20 p. 


\section{Subject Index}

\section{$\mathbf{A}$}

agricultural chemicals, 41

Aitkin County, 10, 13

alachlor, 31

Alimagnet Lake, 18

Anoka County, 7, 12, 13, 15, 23, 35

Anoka Sand Plain aquifer, 12, 16, 35

Apple Valley, Minnesota, 14, 18

Appleton, Minnesota, 15

Aquifer Thermal-Energy Storage, 22, 23, 25, 29, 37, 39

artificial recharge, 14,15

atrazine, 30, 31, 34

Aurora, Minnesota, 9

\section{B}

Becker County, 10, 11, 12, 14, 16, 19, 29, 35, 41

bed-load sampler, 18, 21, 26

bed-material sampler, 8

bedrock, 15

Beltrami County, 10, 17, 19, 31, 32

Bemidji, Minnesota, 22, 26, 27, 28, 29, 33, 35, 36, 37

Bemidji-Bagley area, 31

Benton County, 14, 18, 35

Big Marine Lake, 23

Big Stone County, 9, 15, 18, 23

Big Stone Lake, 9

biotic integrity, 39

Black Dog Creek, 16

Blue Earth County, 13, 33

Blue Earth River, 13, 35

Bois de Sioux River, 9

bottom sediment, 39

bromide, 34

Brooten-Belgrade area, 11, 16, 30, 32

Brown County, 12

Buffalo aquifer, 19

Buffalo River, 10

Burham Creek, 14

buried drift aquifers, 23, see also drift aquifers

\section{C}

calcareous fens, 38, 39

Cambrian-Ordovician aquifer, 19, 20, 29

Camp Ripley Military Reservation, 7

Cannon River, 13

carbonate aquifer, 22

carbonate rock, 15

Carlton County, 5, 12, 17, 23, 29
Carver County, 13, 19

Cass County, 11, 22, 31

Cedar River, 14

Chaska, Minnesota, 19

Chippewa County, 9, 11, 12, 15, 22, 23, 25, 26

Chippewa River, 9, 22, 23, 25, 26

Chisago County, 12, 13, 35

Chisholm- Dewey Lake area, 7

Clay County, 5, 6, 10, 19

Clearbrook, Minnesota, 29

Clearwater County, 10, 31

Clearwater River, 29

Cloquet, Minnesota, 5

coal-tar derivatives, 18, 21, 22, 24, 31

confined-drift aquifers, 23, 25, 30

Cook County, 15, 19

Coon Creek, 23

Coon Rapids, Minnesota, 13

Coteau des Prairie, 31

Cottonwood County, 12, 13, 15, 33

Cottonwood River, 12

Cretaceous aquifer, 23

Crow River, 13

Crow Wing County, 10, 14

Crow Wing River, 11

D

Dakota County, 13, 15, 16, 17, 18, 30, 32, 33

Deer Creek, 17

Des Moines lobe, 6

Des Moines River, 15

Dodge County, 13

Douglas County, 9, 11, 14, 28, 40

drift aquifers, 26 , see also buried drift aquifers

drought, 30,32

Duluth, Minnesota, 7

E

Eagan, Minnesota, 14, 17, 30

Eagle Lake, 18

Elim Creek, 17

Elk River, 7

F

Fairbault County, 13, 35

Fargo-Moorhead area, 5

Farquar Lake, 18

fens, 38, 39

Fergus Falls, Minnesota, 26

Fillmore County, 14, 17

Filson Creek, 19

finite-difference model, 15 


\section{Subject Index-Continued}

flood investigations, $9,10,11,12,14,16,19$

floods, $5,10,14,16,17,28,30,32,38$

focused recharge, 38

Fond du Lac Indian Reservation, 29

Fork River, 15

Freeborn County, 14, 33

Fridley, Minnesota, 24, 31

G

Garvin Brook, 21

geographic information system, 24, 33, 35

glacial drift, 27

glacial-drift aquifers, 26, 27, 31, 32, see also drift aquifers

Gladstone Beach, 7

Goodhue County, 13, 17

Grand Rapids, Minnesota, 11

Grant County, 9, 22, 23, 25, 26, 40

ground-water contamination, 18, 19, 21, 22, 24, 29

ground-water-flow model, 19, 20

\section{H}

Halma-Lake Bronson area, 6, 7

Hastings, Minnesota, 32

Hawk Creek, 12

Helley-Smith bed-load-sediment sampler, 15

Hennepin County, 7, 16, 18, 19, 22, 24, 26, 31

herbicides, $29,30,32,33$

Hibbing, Minnesota, 9

Hollandale Embayment, 20, 21, 26

Hornbeam Lake, 18

Horseshoe Lake, 18

Houston County, 14, 17

Hubbard County, 10, 11, 16, 18, 19, 20, 22, 24, 25 , $27,28,31,35,41$

I

impoundments, 31

Iron Range, 7

Ironton-Galesville aquifer, 20

irrigation, 11, 12, 14, 15, 16, 30, 31, 32

Isanti County, 12, 13, 35

Itasca County, 5, 6, 7, 8, 10, 11, 13, 15, 19

J

Jackson County, 8, 13, 14, 15

Jackson, County, 35

Jordan aquifer, 6

Jordan Sandstone, 8

$\mathbf{K}$

Kanabec County, 13, 23

Kandiyohi County, 12, 13, 16, 18, 28, 30, 32
Keewatin, Minnesota, 33

Kettle River, 12

Kittson County, 5, 6, 7, 8, 9, 25

Koochiching County, 7, 14, 15, 17, 19

$\mathbf{L}$

Lac qui Parle County, 9, 40

Lac qui Parle River, 9, 40

Lake Agassiz, 7

Lake Agassiz peatlands, 19

Lake Bemidji, 32

Lake County, 15, 16, 18, 19

Lake Emily, 10, 11, 16

Lake of the Woods, 14

Lake of the Woods County, 14, 17, 19

Lake Sallie, 12

Lake St. Croix Beach, Minnesota, 11

Lake Superior, 16

Lakeland shores, Minnesota, 11

Lakeville, Minnesota, 18

Lambert Creek, 26, 40

land use, 32, 35, 38

Le Sueur County, 13

Le Sueur River, 33

limnology, 14, 18, 24

Lincoln County, 10, 11, 29, 40

Lino Lakes, Minnesota, 15

Little Falls, Minnesota, 11, 12

Little Rock River, 15

Long Lake, 18

Long Meadow Lake, 16

Lyon County, 5, 6, 7, 9, 10, 11, 12, 29

$\mathbf{M}$

Mahnomen County, 11, 29

Management Systems Evaluation Area (MSEA), 34, $35,36,37,39,40$

Marshall County, 5, 7, 8, 9, 10, 25

Martin County, 13, 35

McLeod County, 13

mercury deposition, 35

Mesabi Iron Range, 5, 6, 8, 13

Mesabi-Vermillion Iron Range, 8, 11, 13

Middle River, 9

Mille Lacs County, 13

Minneapolis-St. Paul area, 5, 6, 8, 9, 12, 13, 14, 15, $17,19,20,21,22,23,29,30,40$

Minnesota River, 12, 13, 20, 29, 31, 33, 38, 39, 40

Mississippi River, 10, 13, 14, 15, 17, 20, 29, 30 . $31,32,40$

Montevideo, Minnesota, 11

Morrison County, 7, 11, 12, 14, 20, 22 


\section{Subject Index-Continued}

Mount Simon-Hinckley aquifer, 19, 20, 21, 22

Mountain Iron-Virginia area, 6

Mountain Iron-Virginia Eveleth area, 8

Mower County, 14

Murray County, 15

Mustinka River, 9

$\mathbf{N}$

National Stream Quality Accounting Network (NASQAN), 14

National Water Information System II (NWISII), 35

National Water-Quality Assessment Program (NAWQA), 33, 40

Nemadji River, 17

Nett Lake Indian Reservation, 7

Nicollet County, 12, 13

nitrate, $30,32,36,38,40$

nitrogen, 38

nitrogen isotopes, 36

Nobles County, 6, 8, 14

nonpoint-source pollution, 20

Norman County, 11, 18

North Dakota, 5, 41

nuclear reactors, 7

nutrients, 41

\section{O}

Olmsted County, 13, 14, 17, 32, 36

Omaday Lake, 19

Orwell Reservoir, 26

Otter Tail County, 9, 10, 11, 12, 14, 19, 20, 22, 26, 40

Otter Tail River, 10, 26

outwash aquifer, 34, see also glacial drift aquifers

\section{$\mathbf{P}$}

Pearl-Sallie Lakes area, 14

Pelican River Sand-Plain aquifer, 19

Pennington County, 10

Perham, Minnesota, 12

pesticides, 38, 41

petrography, 39

Pine Bend, Minnesota, 13

Pine County, 12, 13, 23

Pineland Sands area, 16

Pipestone County, 14, 29

Plummer, Minnesota, 29

Polk County, 10, 14, 25

Pomme de Terre River, 9, 22, 23, 25, 26, 40

Pope County, 9, 10, 11, 16, 22, 23, 28, 30, 32

Prairie du Chien-Jordan aquifer, 14, 19, 20, 21, 22, $24,29,31,33,35$
Princeton, Minnesota, 34, 36, 37, 38, 39, 40

$\mathbf{R}$

radioisotope gage, 10

Rainey Lake, 15

Ramsey County, 24, 26, 40

Red Lake County, 10

Red Lake Indian Reservation, 31

Red Lake peatlands, 17

Red Lake River, 10

Red River, 25

Red River of the North, 5, 12, 17, 33, 34, 35, 38, 39, 40,41

Red River Valley, 25

Redwood County, 8, 11, 12

Redwood Falls, Minnesota, 8

Redwood River, 11, 29

Redwood County, 29

remote sensing, 15

Renville County, 12, 13

report production, 41

Rice County, 13

Rochester, Minnesota, 17, 30, 32, 36

Rock County, 14

Rock River, 14

Rogers Lake, 17

Root River, 14

Roseau County, 5, 8, 9, 14

Roseau River, 9

Royalton, Minnesota, 32

Rum River, 13

\section{$S$}

sand-plain aquifers, $22,23,28,30,34$

sandstone aquifer, 29, 37

Sauk Center, Minnesota, 33

Sauk Lake, 33

Sauk River, 14

Savage Fen, 39

Schmidt Lake, 18

Scott County, 13

sediment sampling, 16

sediment-concentration gages, 27

seepage within lakebeds, 14

Sherburne County, 7, 12, 14, 18, 21, 35

Sherburne National Wildlife Refuge, 21

Sheyenne Delta aquifer, 38

Sibley County, 13, 15

Skunk Creek, 17

Snake River, 13

solid-waste disposal, 11

Solo Church Formation, 21 


\section{Subject Index-Continued}

Souris-Red-Rainey region, 14

South Dakota, 41

South Fork Zumbro River, 17

St. Croix River, 13, 31

St. James, Minnesota, 10

St. Joseph, Minnesota, 27, 29

St. Louis County, 5, 6, 7, 8, 9, 11, 13, 15, 16, 17 , $18,19,29,33$

St. Louis Park, Minnesota, 18, 22, 24, 26, 31

St. Louis River, 17

St. Mary's Point, Minnesota, 11

St. Paul, Minnesota, 37

St. Peter aquifer, 21, 26, 31

St. Peter-Prairie du Chien-Jordan aquifer, 32, 36

Stearns County, 13, 14, 16, 18, 27, 28, 29, 30, 32, 33,35

Steele County, 13

Stephen, Minnesota, 7

Stevens County, 9, 22, 23, 25, 26, 40

Stillwater, Minnesota, 13

Straight River, 30, 31, 35, 41

surficial aquifers, 20, 22, 39

surficial sand-plain aquifers, 23,28

surficial-outwash aquifers, 22 , see also outwash aquifers

suspended sediment, 24, 25, 41

suspended-sediment samplers, $7,8,15,17,19,24$

Swift County, 9, 15, 22, 23, 25, 26, 40

$\mathbf{T}$

taconite tailings, 33

Todd County, 11, 14, 22, 33

Traverse County, 9

triazine, 29, 37

Twin Cities aquifer system, 27, 31

Twin Cities Artesian Basin, 12

Two Rivers, 9

U

U.S. Geological Survey, 16

unsaturated zone, 26, 28, 29, 32, 33, 34, 36, 39

$\mathbf{v}$

Vadnais Lake, 40

Vermillion end moraine, 7

Vermillion Iron Range, 6, 8

Viking Basin, 14

visual-accumulation-tube size analyzer, 12

Voyageurs National Park, 17, 33

w

Wabasha County, 13, 17
Wadena County, 11, 16, 20, 22

Waseca County, 13, 33

Washington County, 11, 13, 23

water use, 22, 28, 34

Watonwan County, 10, 13, 33, 35

Watonwan River, 33

West St. Paul, Minnesota, 15

wetlands, 23, 25, 27, 28, 29

White Earth Indian Reservation, 29

Wild Rice River, 11, 18

wildlife management, 5

Wilkin County, 9, 10, 19

Williams Lake, 18, 19, 22, 24, 25, 27, 28

Willmar, Minnesota, 18

Winnipeg aquifer, 25

Winona County, 14, 17, 21

Wright County, 13, 18, 35

\section{$\mathbf{X}$}

$X$-ray sediment concentration gage, 10

\section{$Y$}

Yellow Medicine County, 9, 10, 29, 40

Yellow Medicine River, 10

$\mathbf{Z}$

Zumbro River, 13 


\section{Author Index}

A

Adolphson, D.G., 16, 17, 18, 20, 21, 25

Aiken, G.R., 32

Akin, P.D., 5, 7

Alberts, E.E., 36

Albin, D.R., 26, 27

Alexander, E.C., Jr., 18, 19, 34, 39

Almendinger, J.E., 32, 36, 38

Amos, G.L., 35, 38

Anderson, D.B., 10, 12

Anderson, H.W., Jr., 12, 13, 14, 15, 17, 21, 23, 24, 28, 35,36

Anderson, J.L.. 32, 34, 35, 36, 37, 39, 40

Armstrong, D.S., 41

Arntson, A.D., 23, 26, 30

Ayers, M.A., 17, 18, 20, 23

\section{B}

Baedecker, M.J., 24, 36, 37

Baehr, A.L., 26, 29, 32

Bailey, P.A., 39

Barbeau, D.S., 32

Barkhus, D.A., 37

Bath, G.D., 8

Bennett, P.C., 36

Benson, D.A., 20

Beverage, J.P., 11, 12, 15, 18, 19, 21, 24, 25, 26

Bidwell, L.E., 9, 10, 11, 12

Bingham, J.W., 6

Bloomgren, P.A., 27

Bohlke, J.K., 37, 38

Books, K.G., 5

Brend, Daniel, 28

Breummen, L.B., 26

Brezolik, P.L., 35

Brietkrietz, Alex, 12

Brigham, M.E., 34, 35, 38, 41

Broussard. W.L., 12, 13, 14, 15, 16, 17

Brown, R.F., 7, 10

Brown, R.G., 20, 21, 23, 24, 25, 26, 27, 29

Busch, J.P., 31

Byers, A.C., 5

\section{C}

Capel, P.D., 29, 30, 31, 32, 33, 37

Carlson, G.H., 10, 11, 12, 16, 17, 30, 32, 38

Chang, F.H., 25

Chang, Fu-Hsian, 26, 28

Clay, David, 35

Colby, V.C., 5, 7, 8

Collier, C.R., 11, 13

Copen, Tyler, 37
Cotter, R.D., 6, 7, 8, 9, 13

Cowdery, T.K., 34, 38, 41

Cozzarelli, I.M., 36

Czarnecki, J.B., 20

D

Delin, G.N., 20, 21, 23, 25, 26, 30, 32, 34, 35, 36, 37, 38 , 39,40

Dempsey, W.J., 5

Dennis, P.E., 5

Deters, M.H., 31

Diedrich, M.M., 17, 18

Dowdy, R.H., 32, 34, 35, 36, 37, 39, 40

Dowling, D.C., 24

Druffel, Leroy, 15

Durum, W.H., 5

E

Eganhouse, R.P., 24, 36

Eger, Paul, 27

Ehrlich, G.G., 15, 19

Eisenreich, S.J., 31, 33, 37, 39

Eister, M.F., 12

Ell, Michael, 39

Emerson, D.G., 34, 39

Emmett, W.W., 15

Enblom, J.W., 39

Engelbrecht, L.G., 22

Engstrom, D.R., 35

Ericson, D.W., 11, 12, 13, 14, 15, 16, 17, 18

F

Farrell, D.F., 12, 13, 14, 15

Felsheim, P.E., 13, 14, 16

Feth, J.H., 9

Ficke, J.F., 14

Fishman, M.J., 21

Freeberg, M.H., 24

Furlong, E.T., 32

Futrell, J.C., 24

G

Garbarino, J.R., 21

Georlitz, D.F., 19

Giacomini, E.G., 17

Gilbert, F.P., 8

Gillies, D.C., 19, 22

Glysson, G.D., 31

Godfrey, R.G., 7

Godsy, E.M., 19

Goff, Karin, 38

Goldstein, R.M., 37, 39

Gothard, W.A., 22 


\section{Author Index - Continued}

Grabbe, R.R., 28

Greeson, P.E., 17

Groschen, G.E., 18, 19

Guetzkow, L.C., 9, 10, 11, 12, 14, 16, 17

Gunard, K.T., 9, 11, 14, 16, 19, 23

Guo, Lifeng, 34, 36, 37, 39

Guswa, J.H., 19, 20

Guy, H.P., 10

\section{$\mathbf{H}$}

Hallgren, J.P., 39

Hatch, J.R., 21

Hatfield, J.L., 36

Have, M.R., 14, 17, 18, 26, 29, 32

Hawkinson, R.O., 14

Healy, R.W., 34, 36, 39

Hein, M.D., 19

Helgeson, J.O., 11, 12, 13, 14, 15, 16

Helsel, D.R., 37

Henning, T.A., 35

Herb, W.J., 29

Hess, J.H., 6

Hicks, J.K., 13

Hollenstein, G.H., 9

Holmen, O.O., 17

Horn, M.A., 18, 20, 22, 23, 25, 31

Hotchkiss, R.H., 32

Hoyer, M.C., 39

Hubbell, D.W., 18, 21, 26

Hult, M.F., 13, 14, 15, 17, 18, 19, 21, 22, 24, 25, 26, 28 , $29,32,33,35,36,37$

\section{J}

Jannis, J.A., 16, 17, 18, 21, 22, 25

Jaques, J.E., 28

Jerabek, L.A., 10, 11

Jones, J.R., 5, 7

\section{$\mathbf{K}$}

Knighton, Ray, 35

Komor, S.C., 34, 36, 39

Kontis, A.L., 19, 20

Krumrie, J.R., 40

L

LaBaugh, J.W., 18, 24

Laird, W.M., 5

Lamb, J.A., 34, 35, 36, 37, 39, 40

Landon, M.K., 33, 34, 35, 36, 37, 38, 39, 40

Langford, R.H., 8

Larson, S.P., 13, 14, 15

Larson-Higdem, D.C., 14, 15

Latkovitch, V.J., 17
Leete. Jeanette, 38

Liesch, B.A., 6, 7

Lindgren, R.J., 31

Lindholm. G.F., 9, 11, 12, 13, 14, 15, 16, 17, 18

Lindskov, K.L., 14, 16

Lorenz, D.L., 26, 28, 29, 31, 33, 35, 37, 38, 40, 41

Lowery, Birl, 35

M

Maclay, R.W., 7, 9, 10, 11, 12

Maderak, M.L., 7, 8, 9

Mandle, R.J., 19, 20

Mann, W.B., IV, 11, 12, 13, 15

McBride, M.S., 12, 14, 15

McGuinness, C.L., 8

McIntosh, W.L., 12

Meuschke, J.L., 5

Miller, R.A., 37, 41

Miller, R.T., 19, 22, 23, 24, 25, 27, 28, 29, 37

Miller, W.A., 7, 10

Minnesota Department of Conservation, 6

Mitton, G.B., 31, 33

Morey, G.B., 21

Moyle, J.B., 5

Myette, C.F., 18, 20, 22, 23, 33

$\mathbf{N}$

Nelson, Luanne,., 21

Nindles, D.B., 30

Noben, N.N.. 26, 28

Nordin, C.F., 16

Norvitch, R.F., 6, 7, 8, 12, 13, 14, 15, 17

Nourse, S.M., 28

Novitzki, R.P., 9, 10, 11

O

Oakes, E.L., 8, 9, 10, 11

Oberts, G.L., 17, 23

Olcott, P.G., 16

Olsen, H.W., 34, 36, 39

$P$

Patterson, G.L., 23, 25

Payne, G.A., 16, 17, 18, 20, 21, 28, 29, 31, 33, 35, 37, 40

Pearson, Eric, 39

Pereira, W.E., 21, 24

Petri, L.R., 8

Pfannkuch, H.O., 14, 15, 25, 28, 33

Piatt, J.J., 37

Pike, G.M., 9

Pinder, G.F., 15

Prato, Tony, 36

Prior, C.H., 5, 6, 8 


\section{Author Index - Continued}

Puckett. L.J.. 4 I

$\mathbf{R}$

Rainwater, F.H., 7

Reeder. H.O.. 10, 12.13.14, 15, 16

Regan, C.P., 34, 36, 39

Regan, C.R., 39

Revesz, Kinga, 37

Rickert. D.A., 12

Roddy, W.R., 35

Rodis, H.G., 6, 7

Rogers, J.E., 6, 7, 8

Ropes, L.H., 10

Rosenberry. D.O., 22, 25, 27, 28

Ross. T.G., 12

Rostad, C.E., 21, 24

Rowan, M.C., 35

Ruhl, J.F., 18, 20, 21, 22, 25, 27, 29, 31, 40

$\mathbf{S}$

Saboe. C.W., 13

Sanocki, C.A., 40

Scarborough, J.L., 25, 28

Schiner, G.R., 6, 7,8

Schmidt, Konrad, 39

Schneider, Robert, 5, 6, 7,8

Schneider, V.R., 15

Schneider, W.J., 10, 11, 12

Schoenberg, M.E., 18, 19, 20, 22, 27, 29, 30, 31, 40

Schottler, S.P., 31, 33

Schulze, P.A., 29, 37

Schwartz, G.M., 5, 8

Schwob, H.H., 10

Scott, C.H., 7

Siegel, D.I., 16, 17, 18, 19, 20, 27, 29, 36

Simon, T.P., 39

Sium, Ogbazghi, 30

Skinner, J.V., 6, 7. 8, 10, 11, 12, 15, 16, 17, 18, 19, 20, $21,22,25,26,27,30,31,33$

Smith, C.J., 19, 31

Smith, S.E., 33, 35, 37, 40

Soukup, W.G., 18, 22

Spieker, A.M., 10, 12

Squillace, P.J., 37

Stark, J.R., 23, 24, 25, 26, 27, 28, 29, 30, 31, 35, 37, 40, 41

Steele, T.D., 13, 15

Stefan. H.G., 25

Sterling, R.L., 39

Stevens, H.H., Jr., 18, 21, 26

Stoner, J.D., 24. 27, 28, 30, 33, 35, 37, 41

Straka, G.C., 5, 7, 10
Streitz, A.R., 27

Strudell, J.D., 27

Sturrock, A.M., 22, 25, 27, 28

Sun. R.J., 15

Susag, R.H., 13, 15

Swain, E.B., 35

Swank, Robert, 36

Szalona, J.J., 33

$T$

Taylor, W.W.. 24

Thomas, H.E., 11

Thompson. G.L., 5.9

Thorn, K.A., 32

Tornes, L.H., 18, 19, 23, 24, 25, 26, 31, 35, 38, 41

Trescott, P.C., 15

Trotta, L.C., 24, 27, 28. 31, 33, 34, 35, 37

Tuttle, M.L.. 37, 38

$$
\mathbf{U}
$$

U.S. Geological Survey, 5. 6, 13, 14, 15, 16, 21, 22

Uebel, M.H., 39

V

VanVoast, W.A., 9, 10, 11, 12

Voss, C.I., 25

W

Walton, M.S., 17

Wanty, R.B., 37,38

Ward, Andrew, 36

Warne, S.A., 16

Water Resources Council, 9

Watts, D.G., 36

Wenzel, L.K., 5

Wershaw, R.L., 20, 21

Wheat, D.E., 10, 12

Wiche, G.J., 37

Wilson, E.J., 35

Winter, T.C., 8, 9, 10, 11, 12, 13, 15, 16, 18, 22, 25, 27 , 28

Winterstein, T.A., 20, 25, 30, 35, 37, 40, 41

Witzgman, F.W., 5.7

Wolf, R.J., 14, 16, 17, 18, 19, 20, 21, 22

Wood, W.W., 15

Woodward, D.G., 20, 21, 23, 24, 26

Wright, H.E., 16

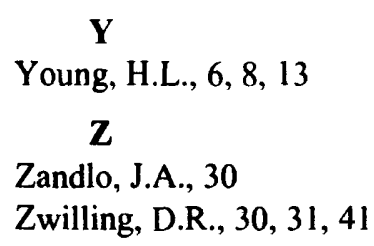

